ORNL/TM-10696

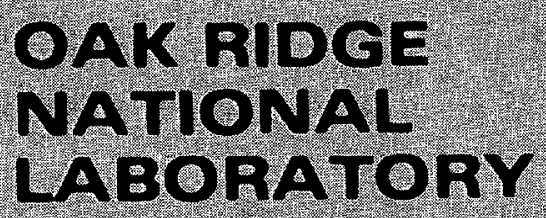

MAGTH MARUETTA

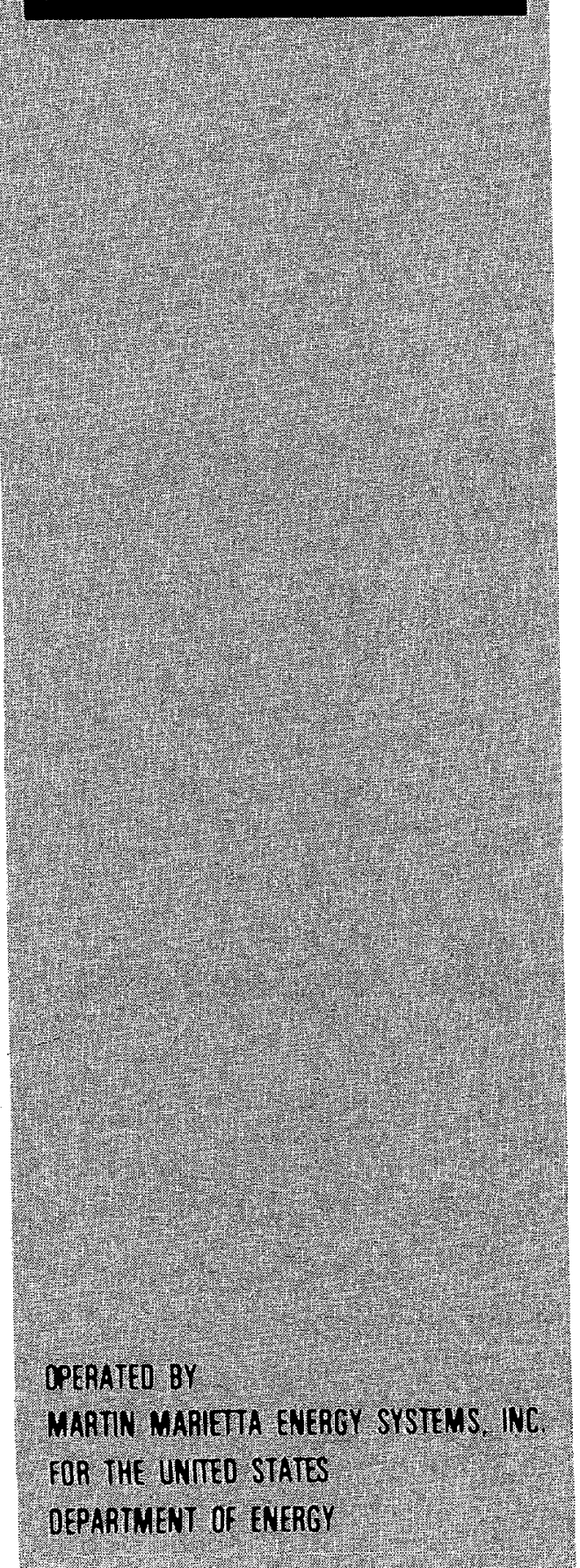

\section{A Review and Analysis of European Industrial Experience in Handling LWR Spent Fuel and Vitrified High-Level Waste}

J. O. Blomeke 


\section{Printed in the United States of America. Available from National Technical Information Service U.S. Department of Commerce 5285 Port Royal Road, Springfield, Virginia 22161 NTIS price codes-Printed Copy: A08 Microfiche A01}

This report was prepared as an account of work sponsored by an agency of the United States Government. Neither the United States Government nor any agency thereof, nor any of their employees, makes any warranty, express or implied, or assumes any legal liability or responsibility for the accuracy, completeness, or usefulness of any information, apparatus, product, or process disclosed, or represents that its use would not infringe privately owned rights. Reference herein to any specific commercial product, process, or service by trade name, trademark. manufacturer, or otherwise, does not necessarily constitute or imply its endorsement, recommendation, or favoring by the United States Government or any agency thereof. The views and opinions of authors expressed herein do not necessarily state or reflect those of the United States Government or any agency thereof. 
ORNL/TM-10696

Dist. Category UC-71 and 85

NUCLEAR AND CHEMICAL WASTE PROGRAMS

(Activity No. DB 040201 1, ONL WZ04)

\title{
A REVIEW AND ANALYSIS OF EUROPEAN INDUSTRIAL EXPERIENCE IN HANDLING LWR SPENT FUEL AND VITRIFIED HIGH-LEVEL WASTE
}

\author{
Compiled and edited by \\ J. O. Blomeke \\ Fuel Recycle Division \\ Oak Ridge National Laboratory \\ Oak Ridge, Tennessee 37831
}

Date Published - June 1988

\author{
Prepared for the \\ U.S. Department of Energy \\ Office of Civilian Radioactive Waste Management \\ Systems Integration Program \\ Prepared by the \\ OAK RIDGE NATIONAL LABORATORY \\ Oak Ridge, Tennessee 37831 \\ operated by \\ MARTIN MARIETTA ENERGY SYSTEMS, INC. \\ for the \\ U.S. DEPARTMENT OF ENERGY \\ under contract DE-AC05-84OR21400
}




\section{CONTENTS}

LIST OF FIGURES

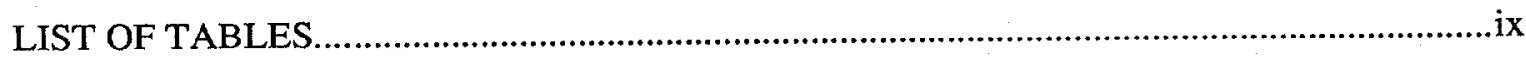

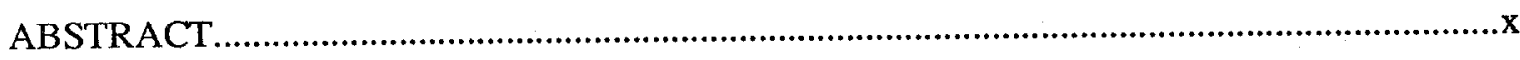

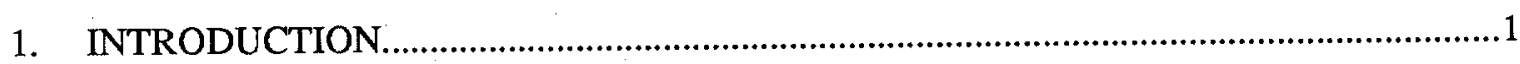

2. FRENCH AND BRITISH SPENT FUEL HANDLING TECHNOLOGY ...............................

2.1 INTRODUCTION …….....................................................................................

2.1.1 Background of Western European Experience in

Nuclear Activities............................................................................................

2.1.2 Structure of the Nuclear Industry ..................................................................

2.1.3 Relationship of Industry to the National Governments....................................5

2.2 SUMMARY AND CONCLUSIONS.......................................................................

2.3 SPENT FUEL TRANSPORTATION....................................................................

2.3.1 Spent Fuel Casks ....................................................................................

2.3.2 Transport Systems ..................................................................................

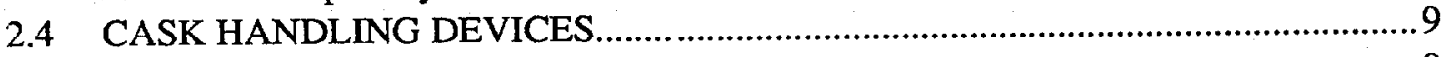

$2.4 .1 \quad$ 130-Ton Bridge Crane................................................................................

2.4.2 Mobile Cask Racks......................................................................................9

2.4.3 Transfer Platform and Storage Area.........................................................12

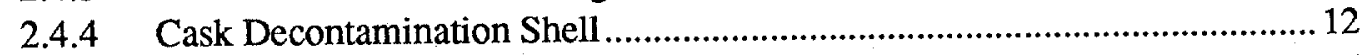

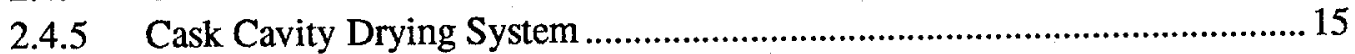

2.4.6 Cask Cooling System......................................................................................15

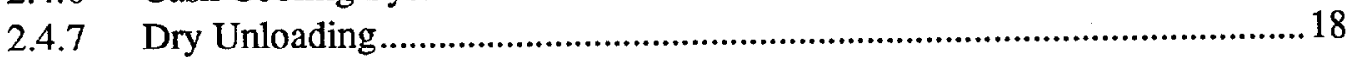

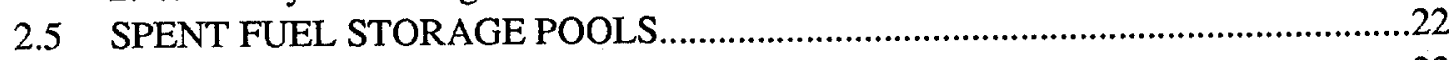

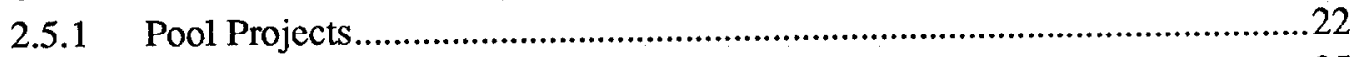

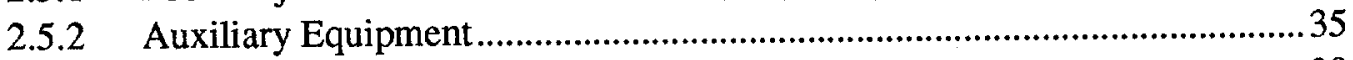

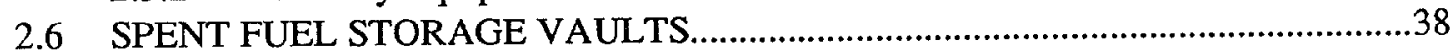

2.6.1 British Vault Storage Designs ..........................................................................38

2.6.2 French Vault Storage Designs ....................................................................44

2.7 DISASSEMBLY AND CONSOLIDATION EQUIPMENT ……..............................51

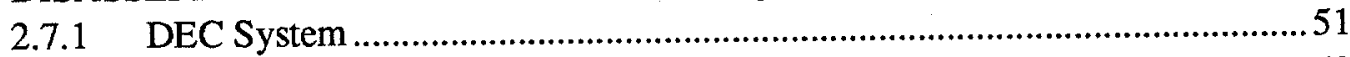

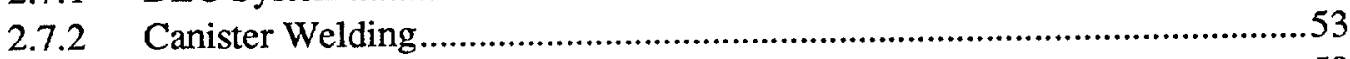

2.7.3 Canister Decontamination.............................................................................5

2.7.4 Canister Monitoring....................................................................................6 


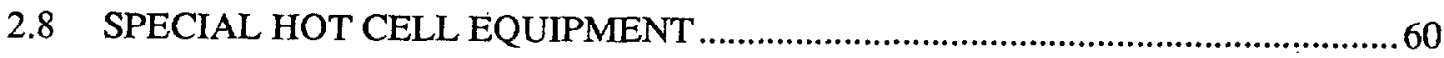

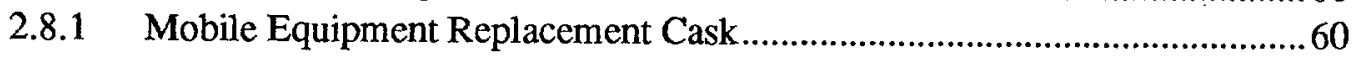

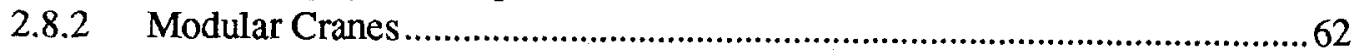

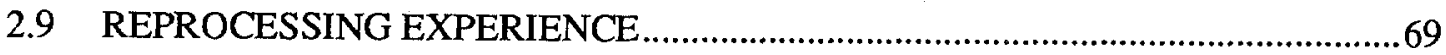

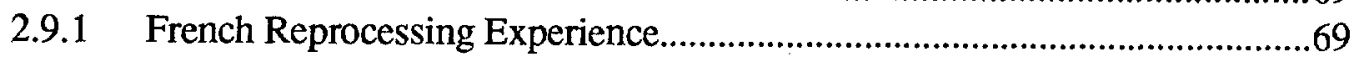

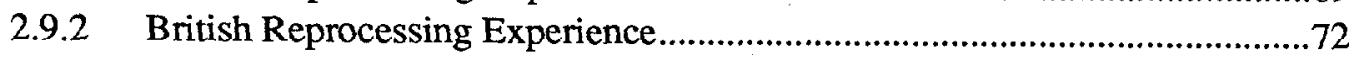

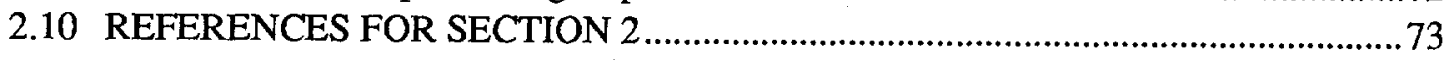

3. SWEDISH SPENT FUEL AND WASTE HANDLING TECHNOLOGY ........................75

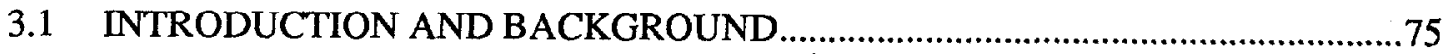

3.2 SPENT FUEL AND WASTE TRANSPORT SYSTEM.......................................77

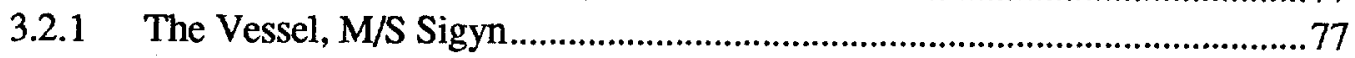

3.2.2 Spent Fuel Shipping Casks ……..........................................................79

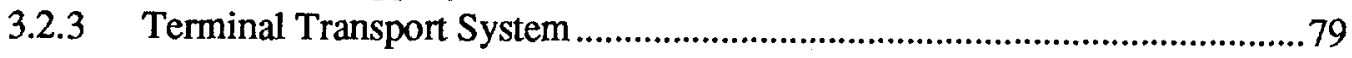

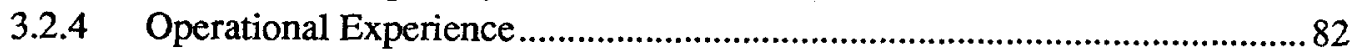

3.3 CENTRAL STORAGE FACILITY FOR SPENT FUEL_CLAB ............................8.

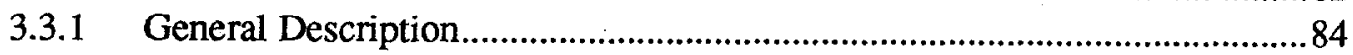

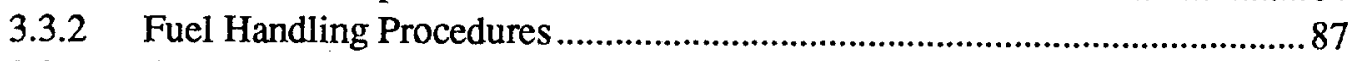

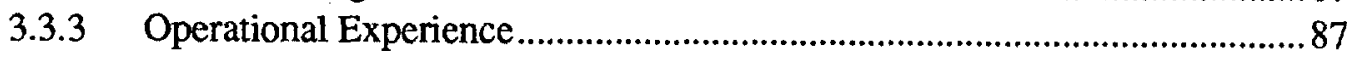

3.4 FINAL REPOSITORY FOR REACTOR WASTE-SFR .......................................89

3.4.1 Waste Categories and Transport System ................................................91

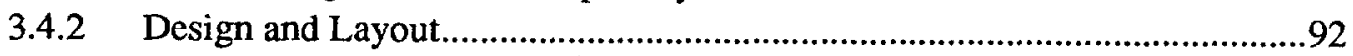

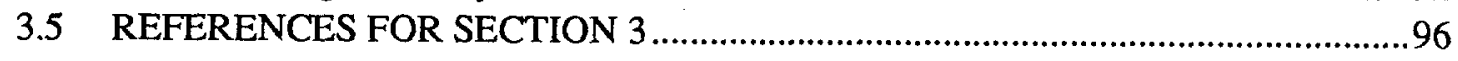

4. SPENT FUEL HANDLING IN THE FEDERAL REPUBLIC OF GERMANY................99

4.1 BACKGROUND OF LWR SPENT FUEL STORAGE .........................................99

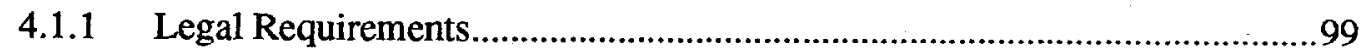

4.1.2 Present Management of Spent Fuel...................................................... 100

4.2 STORAGE FACILITIES AND MAJOR COMPONENTS..................................102

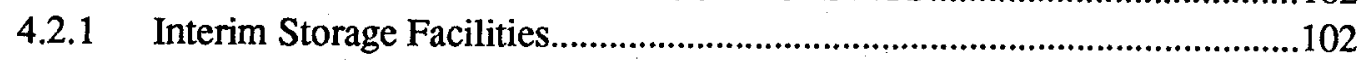

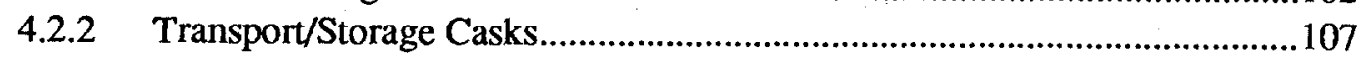

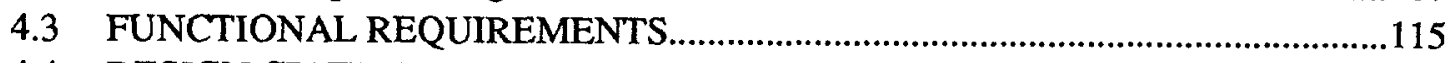

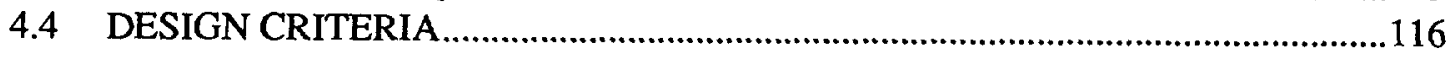

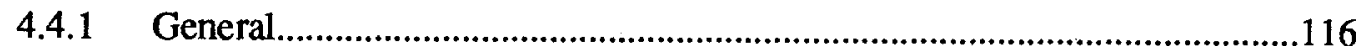

4.4.2 Protection Against External Events....................................................... 116

4.4.3 Protection Against Internal Events.....................................................117

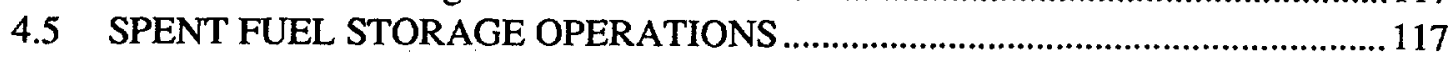

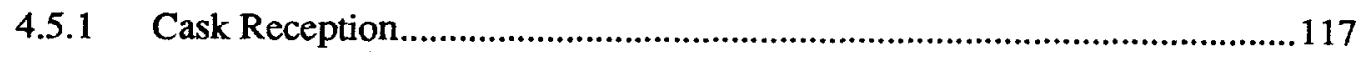

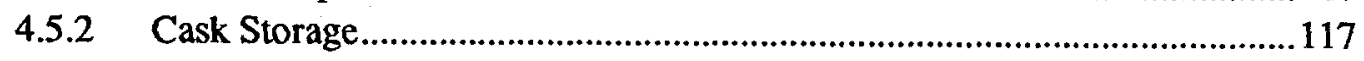

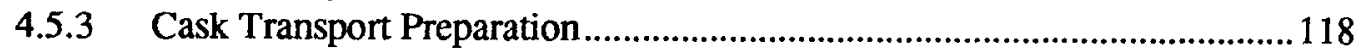

4.5.4 Cask Handling at the Nuclear Power Plants...............................................119

4.5.5 Time and Motion Studies of Cask Handling ............................................ 120

4.5.6 Radiation Exposure of Plant Personnel.................................................. 120 
4.6 STORAGE DEMONSTRATIONS AND INVESTIGATIONS .............................120

4.6.1 Investigation of Spent Fuel Behavior under

Dry Storage Conditions....................................................................... 124

4.6.2 Dry Storage Cask Demonstration.............................................................. 124

4.6.3 Analysis and Simulation of Heat Transfer in

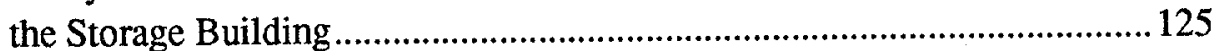

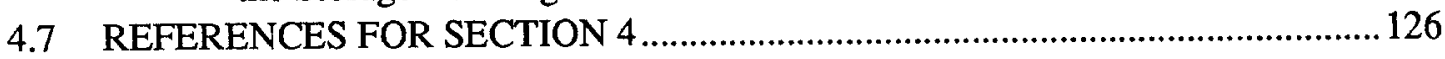

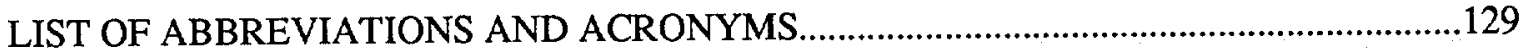




\section{LIST OF FIGURES}

Fig: 2.1. 130-t overhead bridge crane for spent fuel cask handling .......................................11

Fig. 2.2. Mobile rack for spent fuel casks mounted on transfer platform...............................13

Fig. 2.3. Spent fuel transport cask storage area at COGEMA - La Hague Plant..................... 14

Fig. 2.4. Decontamination shell on the upper platform of a cask handling facility.................16

Fig. 2.5. Cask cavity drying system................................................................................ 17

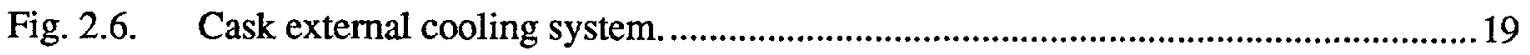

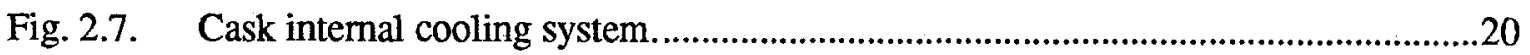

Fig. 2.8. Cask handling operations at dry unloading facility...............................................23

Fig. 2.9. Model of "TO" dry receiving/unloading facility.................................................24

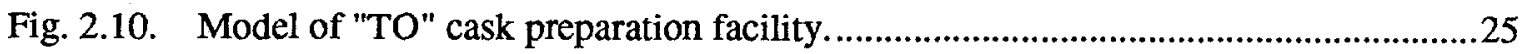

Fig. 2.11. Raising the spent fuel cask into a self-propelled dolly..........................................26

Fig. 2.12. Mating of cask with unloading cell....................................................................22

Fig. 2.13. Schematic diagram of COGEMA - La Hague spent fuel receiving and storage facilities for the UP2-800 and UP3 reprocessing plants.............................29

Fig. 2.14. Schematic flow of spent fuel for NPH facility at COGEMA - La Hague Plant.......30

Fig. 2.15. NPH facility cask unloading pool at COGEMA - La Hague Plant...........................31

Fig. 2.16. NPH facility storage pool at COGEMA - La Hague Plant......................................32

Fig. 2.17. Pole crane for underwater handling of spent fuel storage baskets at

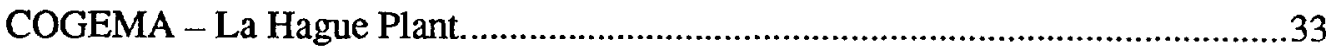

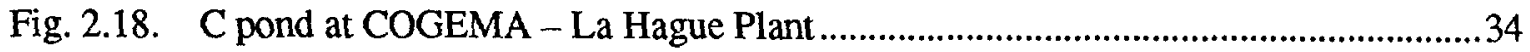

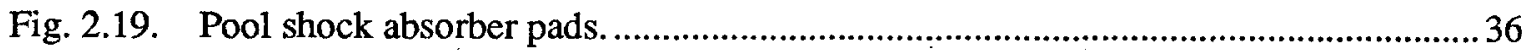

Fig. 2.20. Heat exchanger for spent fuel storage pool ..........................................................3 37

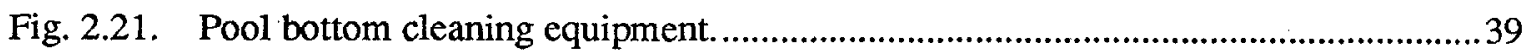

Fig. 2.22. Schematic of modular vault dry storage system.......................................................40

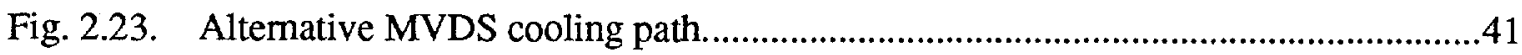

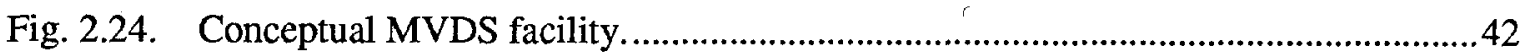

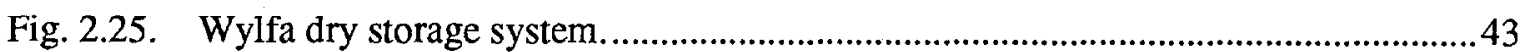

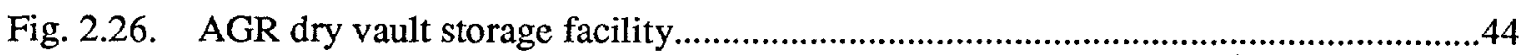




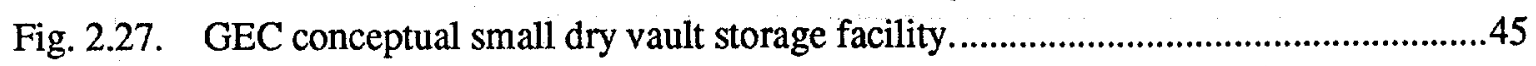

Fig. 2.28. Dry HLW storage facility at COGEMA - Marcoule plant. ...................................47

Fig. 2.29. Diagram of cooling circuits used in dry storage of HLW.....................................48

Fig. 2.30. Dry spent fuel storage facility at the TOR FBR reprocessing plant at Marcoule.....49

Fig. 2.31. DEC spent fuel disassembly and consolidation facility........................................54

Fig. 2.32. Flowsheet for disassembly and consolidation operations (Part I) ...........................55

Fig. 2.33. Flowsheet for disassembly and consolidation operations (Part II) ..........................56

Fig. 2.34. Flowsheet for the volume reduction process.....................................................57

Fig. 2.35. Welding machine for canister lid....................................................................58

Fig. 2.36. High-pressure decontamination system for HLW canisters.................................59

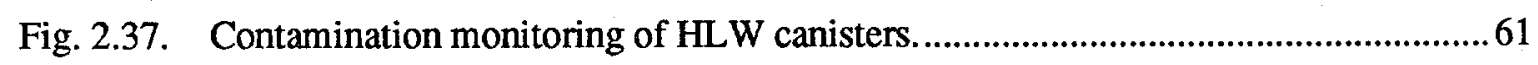

Fig. 2.38. MERC equipment being loaded on a horizontal axis cradle................................63

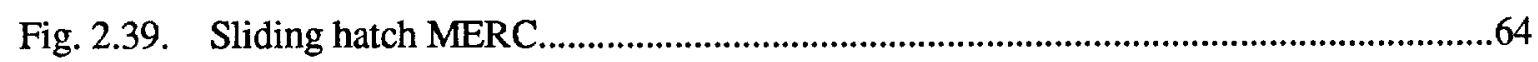

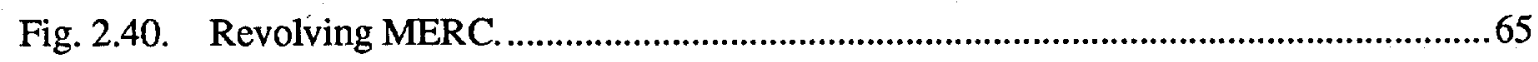

Fig. 2.41. Equipment removal preparation.....................................................................66

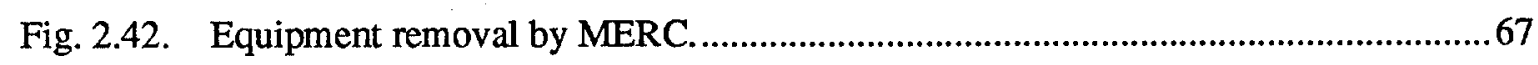

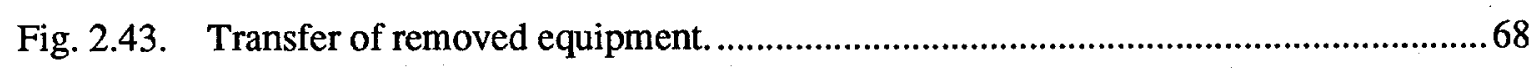

Fig. 2.44. UP2 reprocessing and operational exposure history............................................72

Fig. 3.1. The Swedish nuclear power program.................................................................. 75

Fig. 3.2. Swedish waste management strategy ................................................................ 76

Fig. 3.3. M/S Sigyn at the Simpevarp harbor outside Oskarshamn.....................................78

Fig. 3.4. Transport cask TN 17/Mk2 .............................................................................8

Fig. 3.5. Terminal vehicles with transport casks. ...................................................... 81

Fig. 3.6. Transport flasks secured in the cargo hold of M/S Sigyn.....................................83

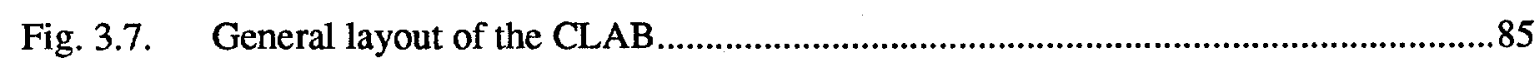

Fig. 3.8. Sequential spent fuel handling steps at the CLAB.............................................86

Fig. 3.9. Layout of tunnels and caverns in the SFR ......................................................90

Fig. 3.10. Site layout of surface facilities...........................................................................93

Fig. 3.11. Tunnels and caverns in construction Phase 1....................................................94

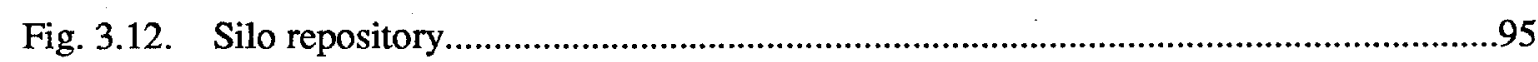

Fig. 3.13. BMA rock cavern for medium-level waste........................................................97

Fig. 4.1. Site plan of the Gorleben interim storage facility.............................................103

Fig. 4.2. Perspective view of the Gorleben interim storage facility.................................. 104 
Fig. 4.3. Sketch of the spent fuel assembly storage hall at Gorleben.................................105

Fig. 4.4. Aerial view of the Gorleben interim storage facility.......................................... 108

Fig. 4.5. CASTOR cask (without spent fuel) in the repair and inspection bay....................109

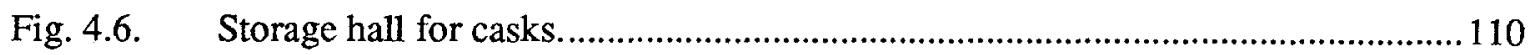

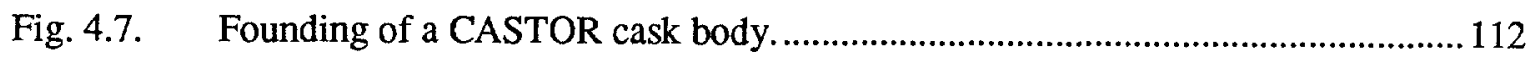

Fig. 4.8. Illustration of a generic transport/storage cask double-lid sealing system............114

Fig. 4.9(a). General flow chart of spent fuel storage operations. ........................................... 118

Fig. 4.9(b). General flow chart of spent fuel storage operations. ........................................... 119

Fig. 4.10. CASTOR cask preparation for loading at a nuclear power plant......................... 121

Fig. 4.11. Upper part of a CASTOR cask showing the basket used to fix the spent fuel assemblies in a safe, predetermined position................................................ 122

Fig. 4.12. Preparations for transport of a CASTOR cask..................................................123

Fig. 4.13. Survey of dry cask storage demonstrations....................................................125 


\section{LIST OF TABLES}

Table 2.1. General description of French spent fuel transport casks........................................8

Table 2.2. Summary description of TN-24 casks.............................................................. 8

Table 2.3. Ocean-going ships transporting radioactive materials......................................... 10

Table 2.4. Characteristics of TOR, AVM, and AVH dry storage facilities............................50

Table 2.4. La Hague (UP2) reprocessing history ................................................................ 70

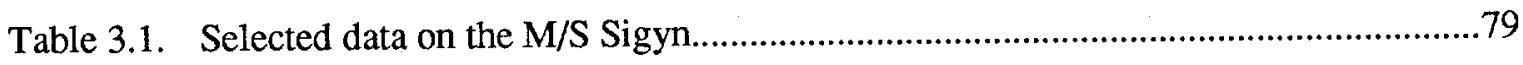

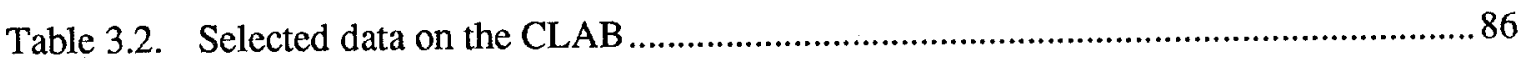

Table 3.3. Comparison of calculated and measured occupational doses ..................................90

Table 3.4. Characteristics of medium- and low-level wastes..................................................91

Table 4.1. Available water pool storage capacities at FRG nuclear power plants and expected dates when filled ................................................................................ 101

Table 4.2. Characteristics of casks acceptable for storage at the Gorleben interim

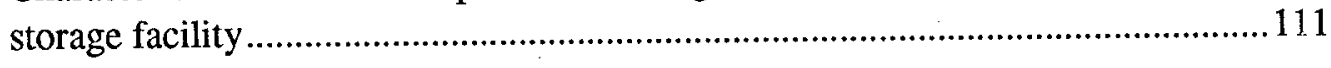




\begin{abstract}
The industrial facilities that have been built or are under construction in France, the United Kingdom, Sweden, and West Germany to handle light-water reactor (LWR) spent fuel and canisters of vitrified high-level waste before ultimate disposal are described and illustrated with drawings and photographs. Published information on the operating performance of these facilities is also given. This information was assembled for consideration in planning and design of similar equipment and facilities needed for the Federal Waste Management System in the United States.
\end{abstract}




\section{INTRODUCTION}

The establishment of a Federal Waste Management System (FWMS) in the United States will require the design, construction, and operation of sizeable industrial-scale facilities for conditioning, transport, storage, and final disposal of spent fuel from light-water reactors (LWRs) and solidified high-level waste (HLW). Although more than 16,000 metric tons of uranium (tU)* have been discharged as spent fuel from LWRs in the U.S., ${ }^{1}$ there is little experience in this country in handling significant quantities of this material after its removal from storage at the reactors. Virtually all of the spent fuel is standing in water pools at the nuclear power stations. Only about $1600 \mathrm{tU}$ have been shipped through $1986,{ }^{2}$ mostly to the reprocessing and away-from-reactor storage facilities at West Valley, New York, and Morris, Illinois. It is projected that by the year 2000 the inventory will reach $42,000 \mathrm{tU}$, and will then be increasing at a rate of 2000 tU/year. ${ }^{1}$

However, in four West European countries, $\dagger$ there are major industrial facilities, and others are being constructed, for spent fuel and HLW management.

- France: short-term (several years) storage followed by reprocessing. Spent fuel is transported from reactors by road, sea, and rail to the La Hague plant where it is stored in ponds until it is reprocessed. The HLW from reprocessing is made into borosilicate glass and stored in air-cooled facilities until disposal 40 to 50 years later.

- United Kingdom (U.K.): short-term storage followed by reprocessing. Spent fuel is transported from reactors by road, sea, and rail to Sellafield where it will be stored in a $1500-\mathrm{tU}$-capacity pond (Fuel Handling Plant) at the Thermal Oxide Reprocessing Plant (THORP) before being reprocessed. The HLW from reprocessing will be made into borosilicate glass at the Windscale Vitrification Plant and stored in an air-cooled facility until its eventual disposal.

- Sweden: disposal of spent fuel without reprocessing. Spent fuel is transported from reactor cooling ponds by specially designed land vehicles and shipped by sca to an existing 3000-tU-capacity central storage facility, CLAB, where it will be stored under water for 30 to 40 years before being conditioned and emplaced in a crystalline bedrock repository.

- Federal Republic of Germany (FRG): interim storage followed by reprocessing or direct disposal. Spent fuel will be transported by road and rail to a 1500 -tU central storage facility in casks designed to serve for both transport and subsequent dry storage. The fuel will eventually be reprocessed or conditioned for disposal in a repository mined in salt.

\footnotetext{
*Throughout this report, the symbol $\mathrm{t}$, as adopted by the International System of Units (SI), is used to denote metric tons, or $10^{3} \mathrm{~kg}$.

†Although the primary emphasis in France, the U.K., and the FRG continues to be based on reprocessing, recent uncertainties in western Europe's nuclear energy future have caused more attention to be given in these countries to the development of contingency plans for long-term storage of the fuel prior to reprocessing or direct disposal.
} 
The design and operating experience of these facilities for handling spent fuel after its removal from reactor storage ponds (and in handling canisters of HLW) can provide valuable input into the design of similar equipment and facilities being planned for the FWMS. The following are some important potential benefits:

- The current industrial practices for high-throughput spent fuel handling operations can be identified.

- A baseline of operating experience can be established and used to improve the design of proposed new facilities in the United States.

- Potential operational problems can be identified and corrected before facility designs are complete.

- Selection of design concepts whose performance has withstood the test of actual operating experience can provide a referenceable path during the licensing process.

This report represents the status of an ongoing assessment of foreign industrial experience in handling LWR spent fuel. It consists principally of descriptions of the technology and equipment that is in use, or is about ready for use, in France, Sweden, the U.K., and the FRG. Although much of this information was taken from open literature, other sources were also used. The French and British technology described in Sect. 2 was prepared by E. R. Johnson Associates, Inc., of Oakton, Virginia, largely from material in their files. The description of Swedish technology in Sect. 3 was taken entirely from the referenced literature, but the review of German technology in Sect. 4 was prepared by Ingenie rgesellschaft GmbH of Hanau, an associate of the NUS Corporation, Gaithersburg, Maryland.

Only a limited amount of information on operating experience was found in the literature. It is expected that the remaining phase of this study will include visits to the principal overseas facilities for the purpose of supplementing the present descriptive information and, more importantly, obtaining the detailcd facility design and operational data that are needed for a meaningful assessment.

\subsection{REFERENCES FOR SECTION 1}

1. United States Department of Energy, IntegratedData Basefor 1986: Spent Fuel and Radioactive Waste Inventories, Projections, and Characteristics, DOE/RW-0006, Rev. 3 (September 1987).

2. W. W. Bixby, "DOE's Program for Transportation of Civilian High-Level Waste-An Overview," Proc. 27th Ann. Meet. Inst. Nucl. Mater. Manage., New Orleans, June 22-26, 1986. 


\section{FRENCH AND BRITISH SPENT FUEL HANDLING TECHNOLOGY*}

\subsection{INTRODUCTION}

This section addresses the French and British technology related to spent fuel and waste handling systems, which has been developed with particular attention to ship/truck/rail cask transfers, cask receiving and storage at La Hague, and HLW canister management at Marcoule and $\mathrm{La}$ Hague. Also, the limited available, nonproprietary information on the design considerations and operational status of the British THORP and the storage facilities at Sellafield is examined.

\subsubsection{Background of Western European Experience in Nuclear Activities}

The nuclear energy technology base of France and the United Kingdom had its inception in the collaboration of scientific representatives of these countries in the United States Manhattan Project. The history of this collaboration and the development of the nuclear industry in France and the United Kingdom, as well as the post-war developments that led to the emergence of a West German nuclear capability, are covered in a comprehensive and very interesting treatise by Bertrand Goldschmidt, ${ }^{1}$ one of the French representatives who worked with the Canadian group.

The initial national efforts were, as might be expected, directed toward the development of a nuclear weapons capability in both the United Kingdom and France, but by 1955 both countries were committed to the development of nuclear technology for the production of electric power. The United States also had a well-developed civilian nuclear power program under way by this time, which followed the demonstration (on a very small scale) of power generation from nuclear energy at the U.S. Atomic Energy Commission's (USAEC) Experimental Breeder Reactor in December 1951 at Arco, Idaho.

Initially, the three countries pursued different courses. The U.K. and France opted for gas-cooled, graphite moderated systems, while the United States investigated several systems on an experimental basis, ultimately settling on the light-water cooled and moderated systems for near-term and liquid sodium cooled fast breeder systems for long-term. Thus, the supporting fuel cycle technology in the three countries did not necessarily follow the same lines. The lesser financial resources available for support of the programs in the United Kingdom and France dictated a greater concentration of effort on single approaches to the solution of technical problems, in contrast to the situation in the United States, where in the 1960s there were seven development projects being supported by the USAEC in high-level waste solidification. The U.K. was at the same time pursuing one approach - a batch pot calcination/vitrification process - and the French developed two systems, a semicontinuous pot calcination/vitrification process and a fully continuous calcination/vitrification process.

*This chapter was taken from the report, Review and Analysis of French and British Technology and Equipment with Potential Applicability to the Federal Nuclear Waste Management System, JAI-298 (July 1987), prepared by E. R. Johnson Associates, Inc., 10461 White Granite Drive, Oakton, Virginia 22124, for Martin Marietta Energy Systems, Inc., Oak Ridge National Laboratory, Oak Ridge, Tennessee 37831, under Contract No. 41XSA094V. 
There can be little doubt that these foreign programs benefited from the technical information published by the USAEC research and development programs in fuel cycle and waste management technology, as well as from the Agreements for Cooperation with the United States that were in various stages of activity over the years. It should be noted however that the greater degree of concentration in technology development within the French and British programs produced original and commendable technology, especially in the case of the French. It might be further noted that the British had the first commercial-scale generation of electricity (albeit from a dual-purpose reactor) in 1965, nearly a year before the Shippingport Plant went into commercial operation. The French operated successfully a full-scale waste solidification facility employing the semicontinuous pot vitrification process from 1967 to 1972 and started up a production facility based on the continuous process in 1977. Both vitrification facilities used the Marcoule Reprocessing Facility high-level waste as feed.

Currently, the British are constructing a production facility for reprocessing oxide-type fuel, in connection with which it is planned to use the French continuous waste vitrification process. This facility will supplement the existing reprocessing facility for Magnox (MX)-clad metallic fuel that has operated for about 25 years. An interesting concept for dry storage of spent nuclear fuel has been developed by GEC Energy Systems and is in use at the Wylfa Nuclear Power Station in Wales (see Sect. 2.6.1).

The French program was redirected in the early 1970s to the LWR types developed initially in the United States, and reprocessing and recycling of plutonium and uranium continue to be an integral aspect of the French nuclear power program. In France, the growing recognition of the dual problems of (near-term) extended storage of spent fuel and of ultimate disposal of HLW has led to a number of innovative developments in these areas.

\subsubsection{Structure of the Nuclear Industry}

The manner in which the nuclear industry developed in the United Kingdom and France paralleled that in the United States until about the time that the United States enacted the Atomic Energy Act of 1954. This Act essentially established the basis for a private nuclear industry and the means for regulating it. During the time period of 1948 to 1951, the USAEC had undertaken a program of reactor technology development within government facilities, which led to the start of construction on the Shippingport power reactor in 1953 and was followed by USAEC-sponsored cooperative programs with private industry to develop, construct, and operate demonstration power reactors. By 1961 the groundwork for a completely private nuclear industry had been laid.

In contrast, in both the U.K. and France the government retained a far greater measure of control and participation in the development, ownership, and operation of the nuclear power generating facilities and the supporting technical enterprises, either directly, or through government-owned, quasi-government entities. The situation in FRG more closely paralleled that in the United States, due in all probability to two facts: the German industry was totally nonmilitary under the terms of the peace treaty, and much of its early technology came from the United States. Today, the German industry is in much the same position vis-a-vis the German government as the U.S. industry is with respect to the U.S. government. The exception to this statement is of course the regulatory situation: in West Germany, government bodies develop national standards (the so-called DINs), but their application to and enforcement on the industry is delegated to the state governments. 


\subsubsection{Relationship of Industry to the National Governments}

There are three areas of interest in respect to the relationship of industry to the national governments in the nuclear technology area: (1) the ownership of the facilities, (2) the character of the participation by private industry, and (3) the regulation by the government of the activity.

Unlike the situation in the United States, neither the U.K. nor France has a regulatory system that provides a broad opportunity for obstructionism in licensing nuclear fuel cycle facilities. In France the nuclear facilities are owned and operated by the national government through the Commissariat a l'Energie Atomique (CEA) and licensed by an independent government entity whose procedures and scope of responsibilities are not too different from the U.S. Nuclear Regulatory Commission (USNRC), with the exception that the provisions for third party intervention and related delays inherent in the U.S. licensing process are not present. A similar situation prevails in the U.K. Technical considerations related to the safety of the operation, as opposed to legal considerations, appear to dominate the licensing process in both the U.K. and France.

Participation by private industry (as opposed to government or quasi-government entities) in the U.K. and France appears to be on a somewhat different basis than in the United States. In France, for example, an organization selected to participate in a particular area of the nuclear enterprise remains the agent of choice for work in that area until proven inadequate for the tasks involved. In some cases, the selected organization has been essentially nationalized, becoming a part of the government-owned entity with operating responsibility. Thus, in 1952 a subsidiary of the Saint Gobain enterprise, Societe Generale pour les Techniques Nouvelles (SGN), was selected as the designated architect engineer/construction manager for fuel reprocessing and radioactive waste management facilities for the French CEA. In 1976 the SGN organization was separated from Saint Gobain, combined with the engineering arm of the CEA subsidiary, Compagnie General des Matieres Nucleaires (COGEMA), and set up as a separate subsidiary that is 64 percent owned by COGEMA.

A generally similar path was followed in the United Kingdom with the United Kingdom Atomic Energy Authority in the position of the Crown organization responsible for all nuclear programs, and later British Nuclear Fuels Limited (BNFL) in the position of the architect engineer/construction manager/operator of the fuel cycle facilities. Nuclear power reactors have been handled in a similar manner in both countries. As noted previously, the situation in West Germany is more nearly parallel to that in the United States.

There is obviously considerable competition for the dwindling amount of business in the nuclear field today. Both France and the United Kingdom, but especially France, are in a position to provide high quality technology and process equipment in nuclear waste management. In the case of France, this has come about as a result of the development programs pursued since the early 1950s. The organization responsible for application of the technology has been a partner of the organization responsiblc for the development of the technology for 35 years and has been an integral part of the development team. This situation must be nearly unique in the nuclear industry in the free world.

\subsection{SUMMARY AND CONCLUSIONS}

The following paragraphs give a summary and some general conclusions of the French and British technology for spent fuel and waste handling systems. Sections 2.3 through 2.8 give a detailed discussion of individual elements of the technology, e.g., transportation casks, handling systems, etc. 
It was found that both the French and British are laking advantage of the experience that they have gained in their earlier reprocessing, storage, and waste management activities in the design of reprocessing facilities having a high reliability of operation as well as lower occupational exposure to radiation. The French have been successful in reducing mean annual occupational exposure in the La Hague reprocessing plant from about 500 mrem/year to below $150 \mathrm{mrem} /$ year over the period of 1976-1986 even though the annual amounts of spent fuel processed were increasing. ${ }^{2}$ The design improvements for the two new reprocessing facilities that they are building presently offer the promise of even lower occupational exposures. These design improvements and others directed toward the reliability of the new plants have resulted from years of development, demonstration, and plant testing in earlier reprocessing facilities. They include (1) the use of standardized equipment which is specifically designed for nuclear service and is capable of rapid, remote dismantling and maintenance; (2) modularization of components that require frequent replacement so that they can be rapidly removed and replaced; (3) the strategic location of equipment items that require frequent repair so that they can be rapidly removed and replacements installed; and (4) the use of a test bed for testing new equipment and systems prior to installation in the plant. While this effort has been directed to reprocessing activities as a whole, many of the designs and removal/installation/maintenance techniques have direct application in the FWMS.

Both the French and the British have developed spent fuel shipping casks and transport systems. However, the French systems are generally more applicable to the United States inasmuch as LWR technology is being utilized in France and is just now being introduced into the U.K. in the form of production scale facilities - although both have offered spent LWR fuel transport services to foreign utilities. The British have had significant technological developments in connection with fuel handling equipment that clearly demonstrate their advanced capability in designing and building complex mechanical devices for fuel handling (particularly for continuous reactor loading and unloading). Although the particular equipment that has actually been produced would find little or no use in U.S. systems, the related technology may be adaptable to use in the FWMS. The British have also had significant experience with the design of water pool spent fuel storage facilities as well as vault storage facilities. While these have been uscd in the U.K. for storage of non-LWR fuel, the basic principles are applicable to LWR fuels as well. However, the details of the designs of these storage facilities and related equipment have not generally been commercially available, with the exception of the British modular dry vault storage system.

On the other hand, the French have developed and publicized a number of design improvements that they made in connection with cask handling, spent fuel storage and consolidation, remote operation and maintenance, and waste processes during the past 20 years. These include the following and are described later in Sects. 2.4 through 2.9: (1) cask handling devices (Sect. 2.4), (2) spent fuel storage pools (Sect. 2.5), (3) dry storage vaults (Sect. 2.6), (4) disassembly and consolidation systems (Sect. 2.7), (5) special hot cell equipment (Sect. 2.8), and (6) reprocessing experience (Sect. 2.9). Many of these equipment items and technological developments could find ready use in the FWMS for specific applications, with little or no modification. Not included in the foregoing list are the auxiliary facilities normally associated with hot cell activities such as HVAC systems, monitoring systems, diesel generators, and control rooms, the designs of which have been materially advanced by the French during the course of their extensive reprocessing and recycle program. 


\subsection{SPENT FUEL TRANSPORTATION37}

\subsubsection{Spent Fuel Casks}

As the operator of the only major oxide fuel reprocessing enterprise currently active, COGEMA (the French Government-owned corporation responsible for nuclear fuel cycle activities and a major owner of SGN) has shipped more than $2000 \mathrm{tU}$ of spent oxide fuel to the La Hague facility during the past 14 years; fuel has been shipped by road, rail, and seagoing transport from 37 power plants owned by 18 different customers in France, Belgium, Germany, Netherlands, Sweden, Switzerland, and Japan. In addition to the oxide fuel, COGEMA has transported more than $4500 \mathrm{tU}$ of metal fuel to La Hague between 1966 and 1982. To accomplish these shipments, COGEMA has used a variety of casks. Initially truck casks were used, but as the number of shipments increased and an interest in the prospects of remote and, if feasible, automated operations at the reprocessing plant developed, standard criteria for rail casks were generated. Special rail cars were also developed for unrestricted use on the European railroads; for the sea shipments, special ships were designed incorporating radiation protection for the crews, radiation instrumentation, and sophisticated communication systems.

As of 1983 Transnucleaire, S. A., and Ets Lemer et Cie, two cask designers, had met the COGEMA standards and criteria and were providing COGEMA-certified casks. These manufacturers provide a series of spent fuel shipping casks, some of which have been certified by COGEMA. Details of the casks are given in Table 2.1 .

The COGEMA-certified casks meet all applicable national (French) regulations and those relating to international shipments by rail, sea, or air. In addition, they meet the IAEA transportation guidelines.

The Transnucleaire casks (TN) are fabricated from carbon steel forgings; material is selected to satisfy the nil ductility requirements below $-40^{\circ} \mathrm{C}$. Heat dissipation is primarily by convection from radial, nickel-plated copper fins brazed to the outer surface of the shell.

Transnucleaire has recently developed a new generation of dual-purpose casks for storage and transport of both PWR and BWR fuels, either intact or consolidated. These are high-payload casks tailored to the common BWR and PWR fuels and have been designed, according to Transnucleaire, to permit licensing for transport when equipped with removable shock-absorbing elements. The cask bodies, in common with the other TN casks, are forged steel surrounded by a neutron shield of resin penetrated by fins for transfer of heat to the outer surface. External fins are required only in the case of consolidated fuel. A cylindrical basket is fabricated of boron stainless steel and copper to control criticality and to transfer heat to the inner shell. Details of this cask, designated as TN-24, are set forth in Table 2.2 .

The Lemer casks (LK) are lead shielded and include a neutron shield of borated water. The heat rejection method consists of an internal device for assuring contact between the fuel basket and the inner shell, supplemented on the outside by special "heat exchangers" that may be adapted to the particular heat removal requirement of any given fuel load.

\subsubsection{Transport Systems}

Although the COGEMA transported about $4500 \mathrm{tU}$ of metal fuel to La Hague plant for reprocessing between 1966 and 1982, transport of LWR fuel did not commence until 1973. As of mid-1983, more than 2000 tU of LWR fuel had been transported to the La Hague plant, and the annual rate of shipment was projected to increase to about $1200 \mathrm{tU}$ per year. Early shipments 
Table 2.1. General description of French spent fuel transport casks

\begin{tabular}{|c|c|c|c|c|}
\hline \multirow[b]{2}{*}{ Identification } & \multirow{2}{*}{$\begin{array}{l}\text { Loaded } \\
\text { weight } \\
\text { (t) }\end{array}$} & \multicolumn{2}{|c|}{$\begin{array}{c}\text { Capacity } \\
\text { (number of spent } \\
\text { fuel assemblies) }\end{array}$} & \multirow{2}{*}{$\begin{array}{c}\text { Heat } \\
\text { dissipation } \\
\text { capability } \\
(\mathrm{kW})\end{array}$} \\
\hline & & BWR & PWR & \\
\hline TN $17 / 2$ & 76 & 17 & 7 & 43 \\
\hline TN $12 / 1^{a}$ & 98 & & 12 & 120 \\
\hline $\mathrm{TN} 12 / 2$ & 102 & 32 & 12 & 93 \\
\hline TN $13 / 2$ & 110 & & 12 & 109 \\
\hline LK $80^{a}$ & 78 & 17 & & $?$ \\
\hline LK 100 & 102 & & 12 & 100 \\
\hline LK $110^{a}$ & 112 & & 12 & $?$ \\
\hline
\end{tabular}

aThese casks have not been certified by COGEMA.

Table 2.2. Summary description of TN-24 casks

\begin{tabular}{lllll}
\hline & \multicolumn{2}{c}{ PWR } & \multicolumn{2}{c}{ BWR } \\
\cline { 2 - 5 } \multicolumn{1}{c}{ Description } & \multicolumn{1}{c}{ Intact } & Consol. & Intact & Consol. \\
\hline Number of fuel assemblies & 24 & 48 & 52 & 104 \\
Length (mm) & 4120 & & 4474 & \\
Basket cavity (mm x mm) & $216 \times 216$ & & $140 \times 140$ & \\
Initial enrichment $\left(\%{ }^{235} \mathrm{U}\right)$ & 3.5 & 3.5 & 3.5 & 3.5 \\
Cooling time $(\mathrm{y})$ & 5 & 7 & 5 & 7 \\
Burnup (MWd/kgU) & 33 & 27 & 33 & 27 \\
Total weight (t) & & & & \\
On crane hook & 104 & 120 & 105.5 & 120 \\
On storage pad & 93.5 & 111.5 & 95 & 112 \\
On vehicle & 98 & 116 & 99.5 & 116.5 \\
\hline
\end{tabular}

were made almost exclusively by truck casks, but by 1975 it was becoming apparent that the use of larger casks would be highly advantageous. Currently, COGEMA uses high-capacity rail casks almost exclusively for spent fuel shipments; truck casks are used only in the few cases where the facility is not capable of handling the larger rail casks. These high-capacity casks are described in Sect. 2.3.1. The transport of large casks from the railhead to the La Hague plant, and from reactors without rail service to their railhead, is accomplished using vehicles similar to those used in Sweden (Sect. 3.2.3). 
Specialized ocean-going ships are used for the transport of spent fuel from overseas sources, employing high-capacity casks of the same type as the rail units. A description of the vessels currently licensed for this purpose is given in Table 2.3.6

\subsection{CASK-HANDLING DEVICES3-5,7-10}

The COGEMA-SGN has developed a series of equipment items for handling spent fuel transport casks, including (1) a bridge crane, (2) mobile cask racks, (3) a cask transfer platform, (4) a cask decontamination shell, (5) a cask drying system, (6) cask cooling systems, and (7) dry unloading equipment. These are described in the following sections.

\subsubsection{0-Ton Bridge Crane}

The 130-ton bridge crane is specially designed for handling spent fuel transport casks. The unit includes a carbon steel crane and trolley assembly. The crane consists of a framework bearing the running rail and maintenance platform. The trolley consists of steel cross members (girders) equipped with a drive roller and three bearing rollers, a gear motor with a brake incorporated with an electromagnetic control, a cable winch and two cable drums, and hoisting brakes (motor disc at shaft end and an auxiliary brake acting on a drum between the motor and the speed reducing gear). The crane is also fitted with a load limiter; hoisting height safety devices and an anticollision system; redundant limit switch contacts on $\mathrm{x}$ and $\mathrm{y}$ axes; stopping devices that activate in event of short circuits, overload, and power outage; and a manual emergency stop button. Maintenance operations on the crane are performed using a 15-ton crane mounted above the 130-ton crane. The crane system design is complete with a pool immersion rod, arm storage station, and an accessory storage station. The crane has the following characteristics:

$\begin{array}{ll}\text { Range } & 16 \mathrm{~m} \\ \text { Hoisting Height } & 22 \mathrm{~m} \\ \text { Speeds } & \\ \quad \text { Hoisting } & 0.5 \text { and } 2 \mathrm{~m} / \mathrm{min} \\ \quad \text { Directional } & 3.3 \text { and } 10 \mathrm{~m} / \mathrm{min} \\ \quad \text { Translational } & 17 \text { and } 10 \mathrm{~m} / \mathrm{min} \\ \text { Installed Power } & 67 \mathrm{~kW}(\mathrm{e}) \\ \text { Limited Failure Rate } & 10^{7} / \mathrm{year} \\ \text { (Load drop hazard) } & \end{array}$

The unit has undergone systematic nondestructive testing before and after assembly. This type of equipment has been installed in three different facilities at the COGEMA-La Hague plant. Figure 2.1 is a photograph of the crane.

\subsubsection{Mobile Cask Racks}

Mobile racks ( $9.3 \mathrm{~m}$ long and $3.1 \mathrm{~m}$ wide) have been designed for supporting spent fuel transport casks while they are being moved and stored on-site in a horizontal position. The racks consist of a rigid carbon steel frame with four supports for engaging and securing both the front and the rear cask trunnions. The supports are fitted with interchangeable bearings to 
Table 2.3. Ocean-going ships' transporting radioactive materials ${ }^{6}$

\begin{tabular}{|c|c|c|c|c|c|c|c|}
\hline \multirow[b]{2}{*}{ Motor vessel } & \multirow{2}{*}{$\begin{array}{l}\text { Operational } \\
\text { date }\end{array}$} & \multirow[b]{2}{*}{ Carrier } & \multirow{2}{*}{$\begin{array}{l}\text { Nominal } \\
\text { deadweight } \\
\text { (t) }\end{array}$} & \multicolumn{2}{|c|}{$\begin{array}{c}\text { Capacity } \\
\text { (number of casks) }\end{array}$} & \multirow{2}{*}{$\begin{array}{l}\text { Draught } \\
\text { (m) }\end{array}$} & \multirow{2}{*}{$\begin{array}{l}\text { Length } x \\
\text { breadth } \\
\text { (m) }\end{array}$} \\
\hline & & & & LWR & Magnox & & \\
\hline Hinorua Maru & 1978 & $\mathrm{NFT}^{b}$ & 1300 & 4 & & 4.20 & $77.5 \times 12.2$ \\
\hline Pacific Swan & 1979 & PNTL $^{\circ}$ & 3000 & 20 & 4 & 6.02 & $103.9 \times 16$ \\
\hline Pacific Crane & 1980 & PNTL & 3000 & 24 & & 6.02 & $103.9 \times 16$ \\
\hline Mediterranean Shearwater & 1982 & BNFL & 1200 & 6 & 6 & 4.50 & $80.0 \times 12.5$ \\
\hline Pacific Teal & 1982 & PNTL & 3000 & 24 & & 6.02 & $103.9 \times 16$ \\
\hline Sigyn & 1982 & $\mathrm{SKB}^{d}$ & 2000 & 10 & & 3.95 & $87.0 \times 18$ \\
\hline Pacific Sandpiper & 1985 & PNTL & 3000 & 20 & 8 & 6.02 & $103.9 \times 16.5$ \\
\hline Pacific Pintail & 1987 & PNTL & 3000 & 24 & & 6.00 & $103.9 \times 16.5$ \\
\hline
\end{tabular}

-These ships have the cargo lifted on and off by cranes, except for Sigyn, which also has a roll-on/roll-off capability. The deadweight tonnage is a measure of the carrying capacity of cargo, fuel, stores, and crew.

'Nuclear Fuel Transport, Tokyo.

•Pacific Nuclear Transport, Ltd.

${ }^{\triangleleft}$ Swedish Nuclear Fuel and Waste Management Company. 


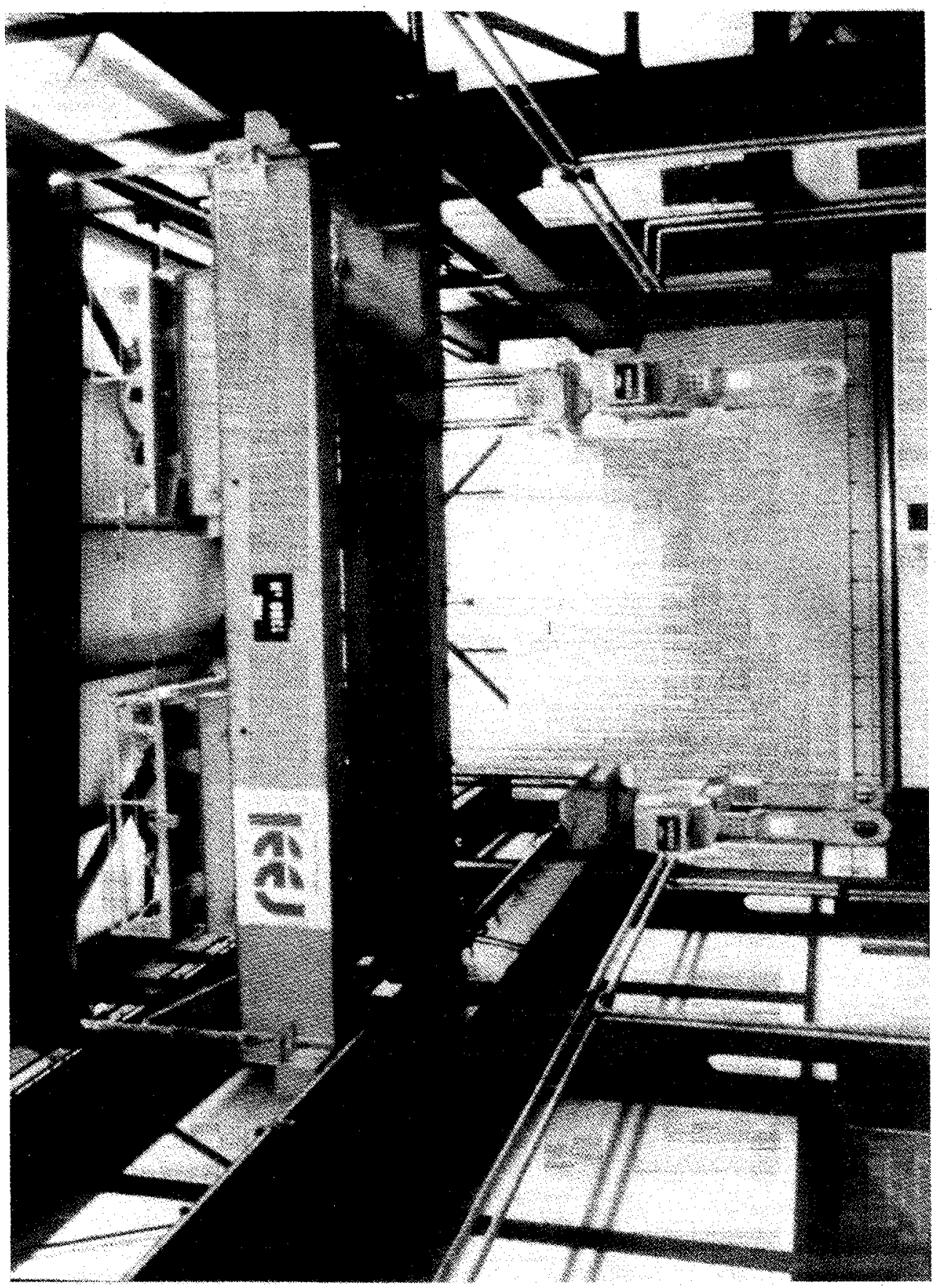

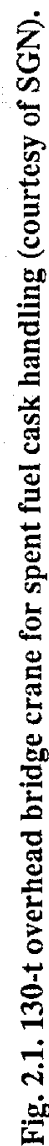


accommodate different cask diameters. The rear bearings are used to raise the cask into a vertical position (using an overhead crane) and are equipped with removable bronze rings. The rack is equipped with wheels mounted on axles which have a $5^{\circ}$ maximum swiveling angle to enable it to be moved around the site on rails. The racks are moved either by tractor or a transfer platform (3-6 mph).

A number of these units have been used at the COGEMA-La Hague plant since 1975. Figure 2.2 pictures a cask on the mobile rack.

\subsubsection{Transfer Platform and Storage Area}

A compact cask storage area design has been developed which consists of a series of parallel rail tracks mounted in a concrete pad. A transfer platform moves through the center of the storage area in a shallow trench which is recessed from the level of the storage area (by $0.7 \mathrm{~m}$ ) and which runs perpendicular to the direction of the parallel tracks of the storage area. The platform rides on three rails imbedded in concrete in the trench, on three rows of four rollers. Two variable-speed electric motors drive three of the roller sets (one per rail). Electricity is supplied to the motors by means of a cable reeled off a drum installed on the platform with a power supply connection at the midpoint of the trench. The surface of the platform is equipped with rails onto which a mobile rack (see Sect. 2.4.2) can be rolled and is flush with the surface of the storage area so that the tracks on the platform can be precisely aligned with the tracks of the storage area. Maintenance pits, each about $9 \mathrm{ft}$ deep, are located at each end of the transfer platform trench.

The mobile rack containing a spent fuel transport cask is rolled onto the platform and secured in position. The platform is then moved laterally (to the axis of the cask) to the assigned storage track and locked into position, and the mobile rack is moved into a storage position. Emergency stops are provided on the platform, and stops are provided in the storage area for locking the cask (on the mobile rack) in position. The platform is capable of traveling at 1.1 and $11.5 \mathrm{~m} / \mathrm{min}$. Transfer of mobile racks with casks mounted thereon is performed using an automated cycling device inside the operator cabin on the platform.

This type of equipment has been used at the COGEMA-La Hague plant since 1978. A second transfer platform and storage area has been operational there since late 1985 . Figure 2.3 is a view of the storage area with the transfer platform trench in the foreground.

\subsubsection{Cask Decontamination Shell}

A system has been developed for decontamination of the externals of a spent fuel shipping cask and its protective skirt after removal from a cask unloading pool. The system consists of a metallic shell into which the cask is placed for decontamination purposes and which provides containment for the cask and the high-pressure water for decontamination.

Upon removal from the unloading pool, the cask is placed on a rotating table, and the metallic shell is placed over the cask. Tightness between the shell and the rotating table assembly is provided by means of an inflatable seal. The cask is decontaminated in the shell by means of high-pressure water spray system consisting of (1) an upper pipe with seven spray nozzles, and (2) a vertical pipe, adjustable to each cask type and equipped with three independent spray systems, the combination of which is supplied at a rate of $90 \mathrm{gal} / \mathrm{min}$ at a nozzle pressure of 3675 psi. An upper circular pipe sprays a water screen on the wall of the shell at a rate of 45 gal/min to prevent its contamination. The shell is also equipped with Plexiglas viewing windows and with individual hand-operated spray nozzles for use on those parts of the cask that require additional decontamination; these nozzles operate at a pressure of 735 psi using water at $140^{\circ} \mathrm{F}$. 


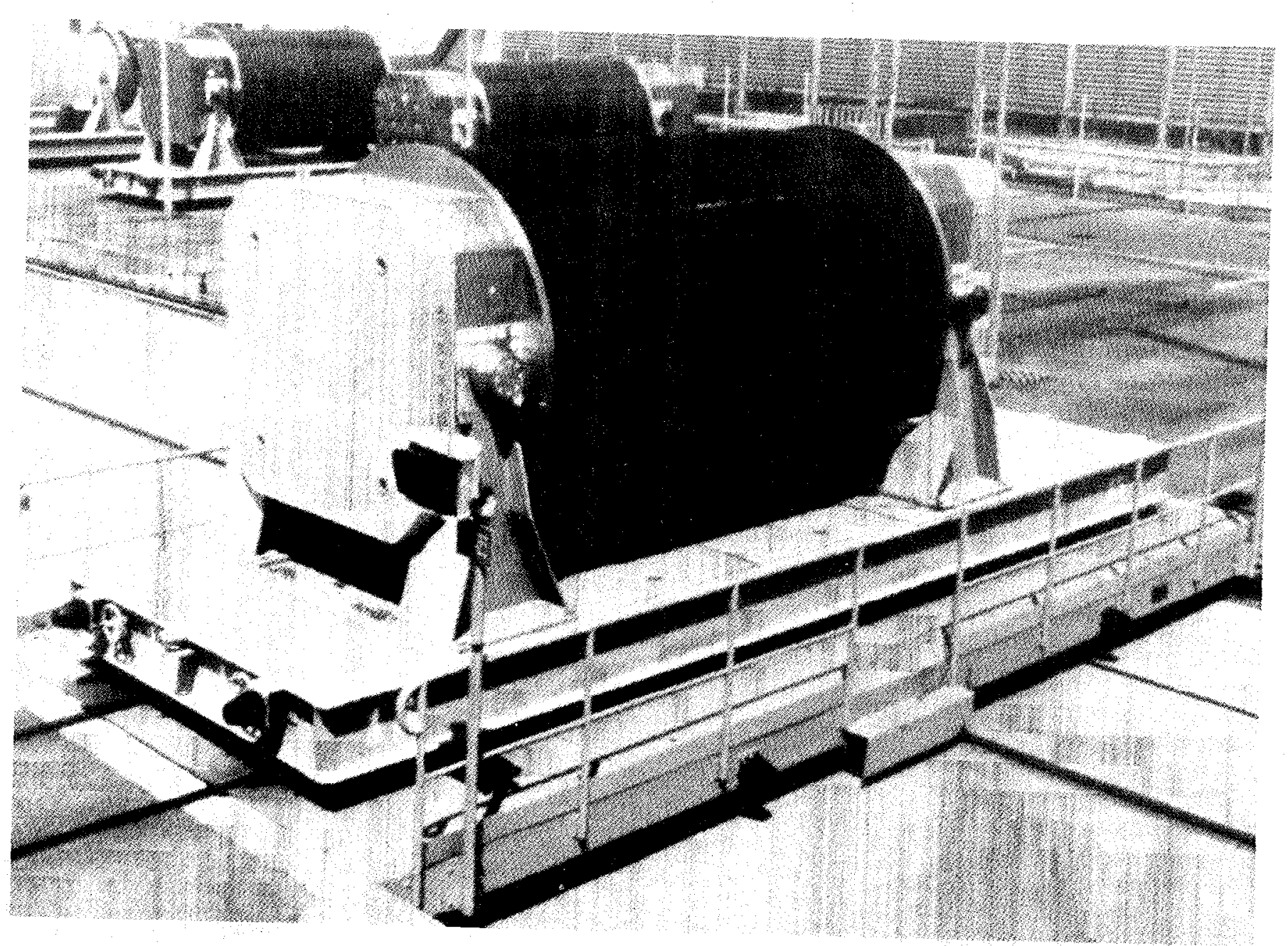

Fig. 2.2. Mobile rack for spent fuel casks mounted on transfer platform (courtesy of SGN). 


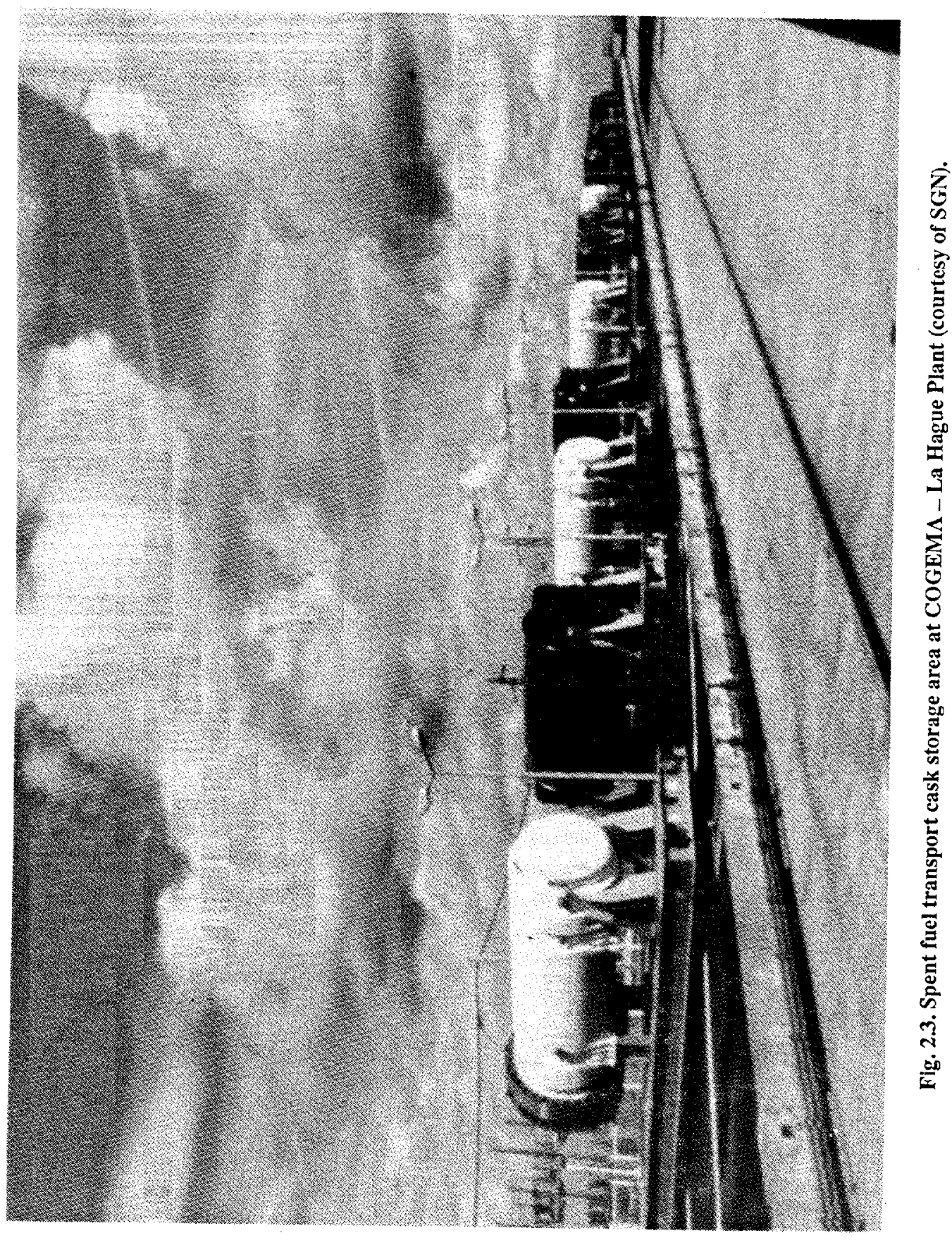


This system has been successful in cleaning and drying a cask in $3 \mathrm{~h}$. It is sufficiently flexible to accommodate every kind of transport cask and is efficient inasmuch as cask surfaces can be decontaminated readily to $10^{-10} \mathrm{Ci} / \mathrm{cm}^{2}$, with a small volume of low-activity water resulting as effluent. Two such systems have been installed and are in operation at La Hague (1973 and 1978). Another system has been installed at the CLAB in Sweden (see Sect. 3.3).

The decontamination shell is available as a package unit. Figure 2.4 shows the decontamination shell on the upper platform of a cask handling facility.

\subsubsection{Cask Cavity Drying System}

A system has been developed for drying the cavity of a spent fuel transport cask after removal from a cask loading and unloading pool. Removal of water from a cask is necessary to meet transport regulations which require that the casks be free of liquids, and to prevent corrosion of any aluminum alloys used for any internal cask structures.

After fuel loading or unloading and decontamination of the cask externals, the interior of the cask is drained and dried. Drying is accomplished by depressurizing the cask interior to $10 \mathrm{~mm} \mathrm{Hg}$ with a vacuum pump. The water evaporates and is collected in a cold trap as ice. The ice is then melted and the resulting water is routed to a low-level waste treatment station. The dry air effluent from this operation is filtered prior to its release to the facility ventilation system using a consumable filter that can be replaced either manually or remotely. The entire system can be mounted on skids and connected to the cask and to the liquid and gaseous effluent treatment systems.

This systcm has been successful in realizing an average drying time of $40 \mathrm{~min}$ for a TN-12 type rail cask having a cavity volume of $4 \mathrm{~m}^{3}$. Two such systems have been installed and are in operation at the COGEMA-La Hague plant (1973 and 1978), and a third system has been installed there recently. Another was installed at the CLAB in Sweden (Sect. 3.3).

The drying system is available as a package unit for use at reactors. Figure 2.5 shows a permanently installed version of this system.

\subsubsection{Cask Cooling Systems}

Two cooling systems, external and internal, for spent fuel transport casks have been developed. They are described in the following sections.

\subsubsection{External cooling system}

This system is used to cool loaded spent fuel transport casks to an appropriate temperature prior to emplacement of the cask in the unloading pool. The system is composed of:

1. a stainless-steel protective skirt having dimensions specific to each type of cask handled and tight-fitted to the cask shell through the use of inflatable seals (the skirt protects the fins of the cask" from contamination by the pool water and allows cold, clean water to circulate between the cask surface and the skirt to remove residual heat); and

2. a cooling circuit consisting of a tubular heat exchanger, a 2100-gal cold water supply tank with makeup capability, and two centrifugal circulation pumps. 


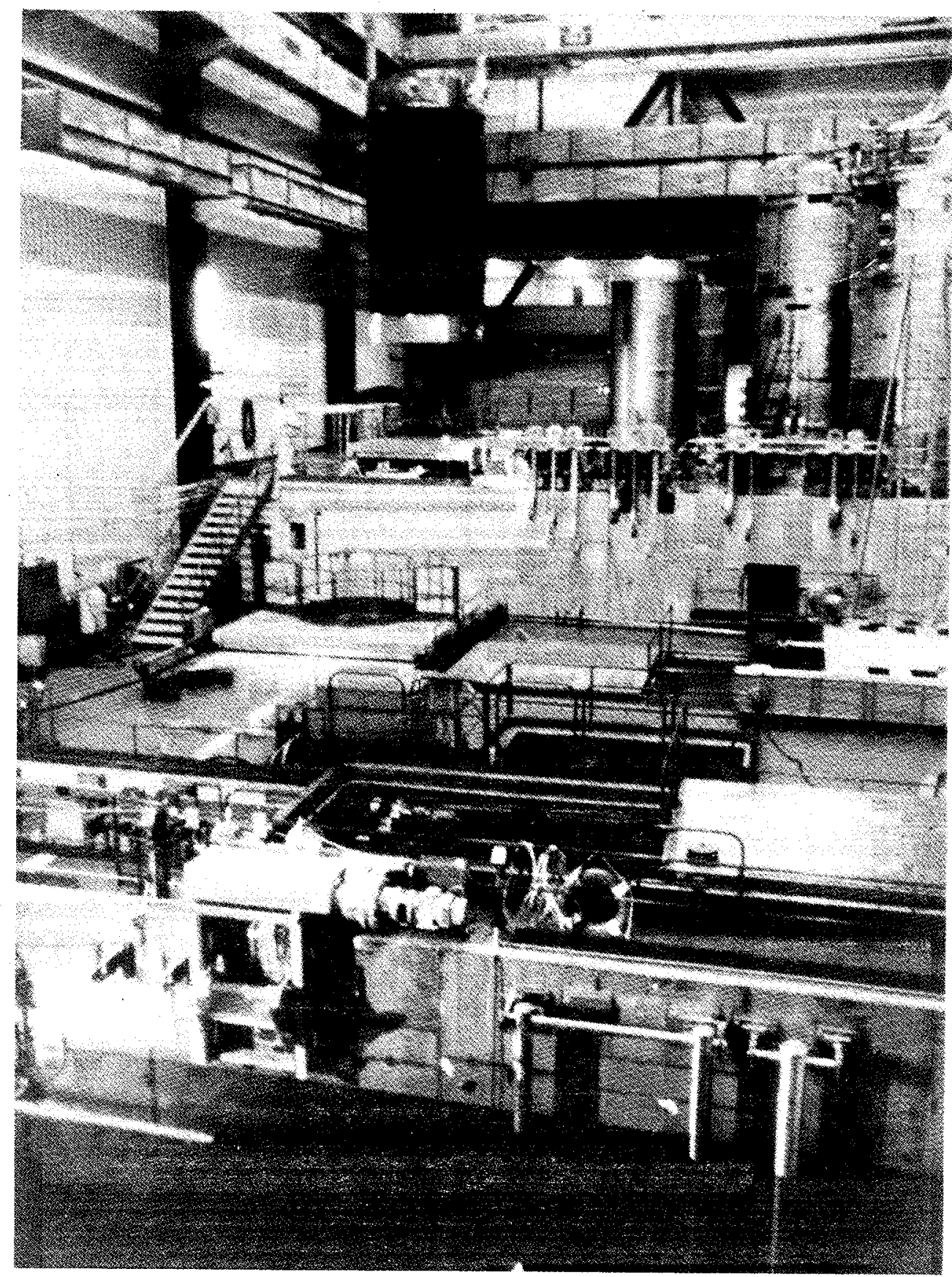

Fig. 2.4. Decontamination shell on the upper platform of a cask handling facillty (courtesy of SGN). 


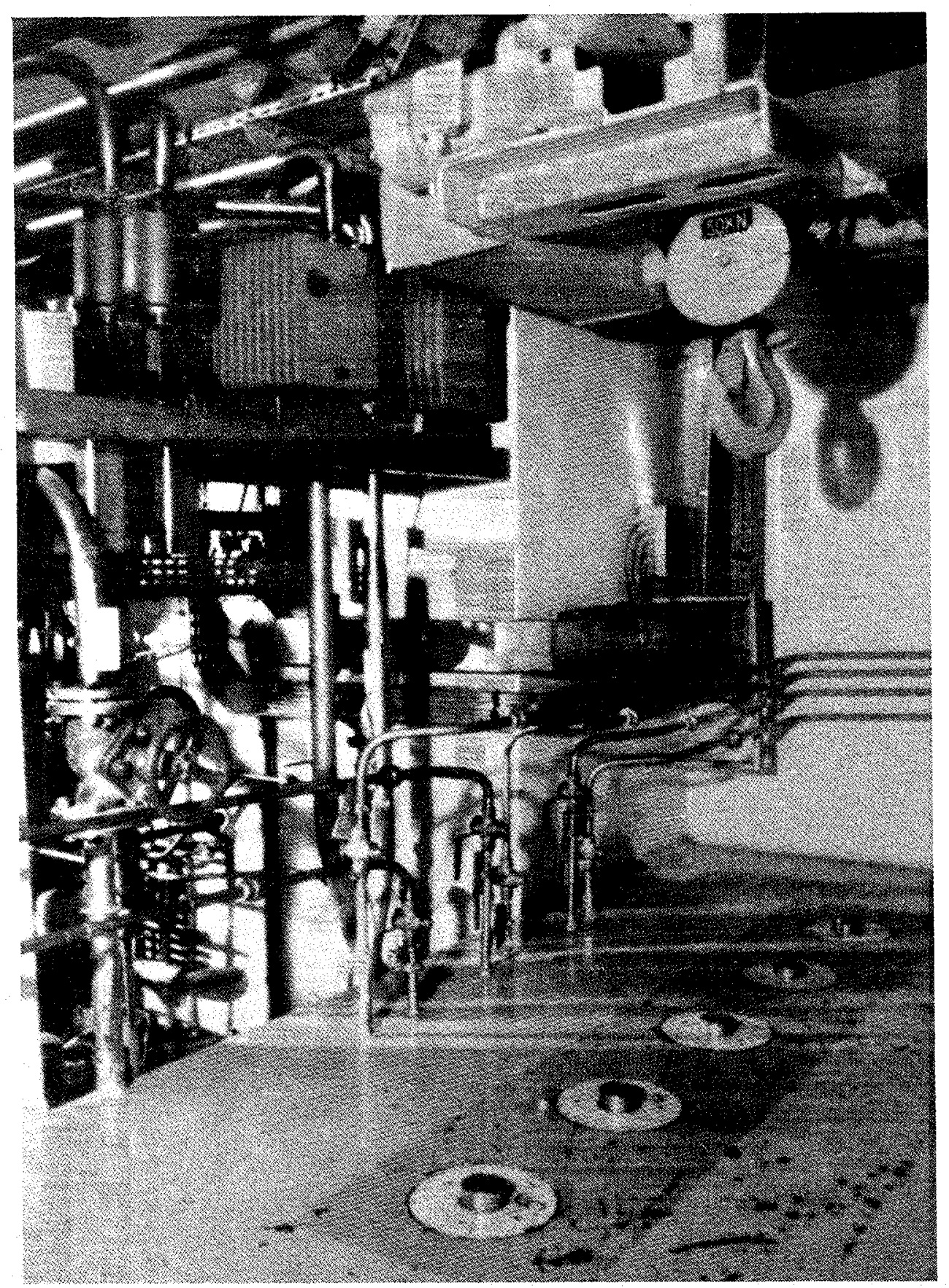

Fig. 2.5. Cask cavity drying system (courtesy of SGN). 
Cooling water is supplied at $20^{\circ} \mathrm{C}$, and the system is capable of cooling a spent fuel cask having a residual thermal power of up to $85 \mathrm{~kW}$. The system has a demonstrated efficiency and reliability and is easy to operate. One system (the NPH) was installed at the La Hague facility in 1978 for casks having a heat dissipation rate of $40 \mathrm{~kW}$ and is in use there currently. A second system was commissioned at La Hague in 1983 for casks with a heat dissipation capability of 85 $\mathrm{kW}$, and a $40-\mathrm{kW}$ system was installed at the CLAB. Figure 2.6 shows a diagram of this system.

\subsubsection{Internal cooling system}

This system is used to (1) cool the fuel assemblies and the metallic mass of the cask and basket, (2) rinse out the cask cavity and flush particulates detached from the fuel during transport, and (3) detect possible cladding failure. The system is composed of the following:

1. a stainless steel protective skirt;

2. a cooling circuit consisting of a tubular heat exchanger, a $1.9-\mathrm{m}^{3}$ cold water supply tank with makeup capability, a 20 -micron stainless steel filter with a capability of being backwashed, and a centrifugal pump;

3. a cask turntable;

4. a mobile platform (to enable the operator to reach different points on the cask);

5. motorized tools for effecting connections to the cask; and

6. monitoring probes.

Cooling water is supplied at $20^{\circ} \mathrm{C}$.

The cask is placed on the turntable in a "preparation" pit, and the protective skirt is installed. After connection to the cooling circuit, the cask cavity is filled with demineralized water, and water circulation is started. Steam produced is desuperheated, and the water is filtered and then cooled in the heat exchanger. The gaseous atmosphere is monitored for the presence of $\mathrm{Kr}-85$, resulting from cladding failure. The activity of the water in the cask is generally reduced to less than $5 \times 10^{-5} \mathrm{Ci} / \mathrm{L}$. Minimal effluents and radioactive wastes are produced during the operation.

The system can be adapted to a number of different types of casks and can be operated with an accompanying low level of exposure to personnel. Three such systems have been installed and are in operation at the La Hague plant $(1973,1978$, and 1983), with the latest being used for casks having a residual thermal power of $80 \mathrm{~kW}$. A fourth system has been installed at the CLAB. Figure 2.7 is a schematic drawing of the system.

\subsubsection{Dry Unloading}

Although the French have not generally stored spent fuel in dry facilities, a dry spent fuel receiving and unloading facility, called the TO facility, was designed by SGN, constructed at the La Hague plant, and started operation in 1986. This facility provides the structures, equipment, and scrvices necessary to receive, unload, and transfer spent fuel assemblies for emplacement in storage. It includes a receiving and shipping building, a cask preparation cell, and a cask loading/unloading cell which features dry unloading of transportation casks with a maximum thermal release of $85 \mathrm{~kW}$, dimensions of $2.3 \mathrm{~m}$ in diameter by $6.9 \mathrm{~m}$ long, and weights of $110 \mathrm{t}$. By April 1987 the TO facility had been used to unload 50 casks of PWR and BWR spent fuel. The average occupational exposure rate was $50 \mathrm{mrem} / \mathrm{year}$, which compares with an average exposure rate of $300 \mathrm{mrem} /$ year for wet unloading at La Hague. 


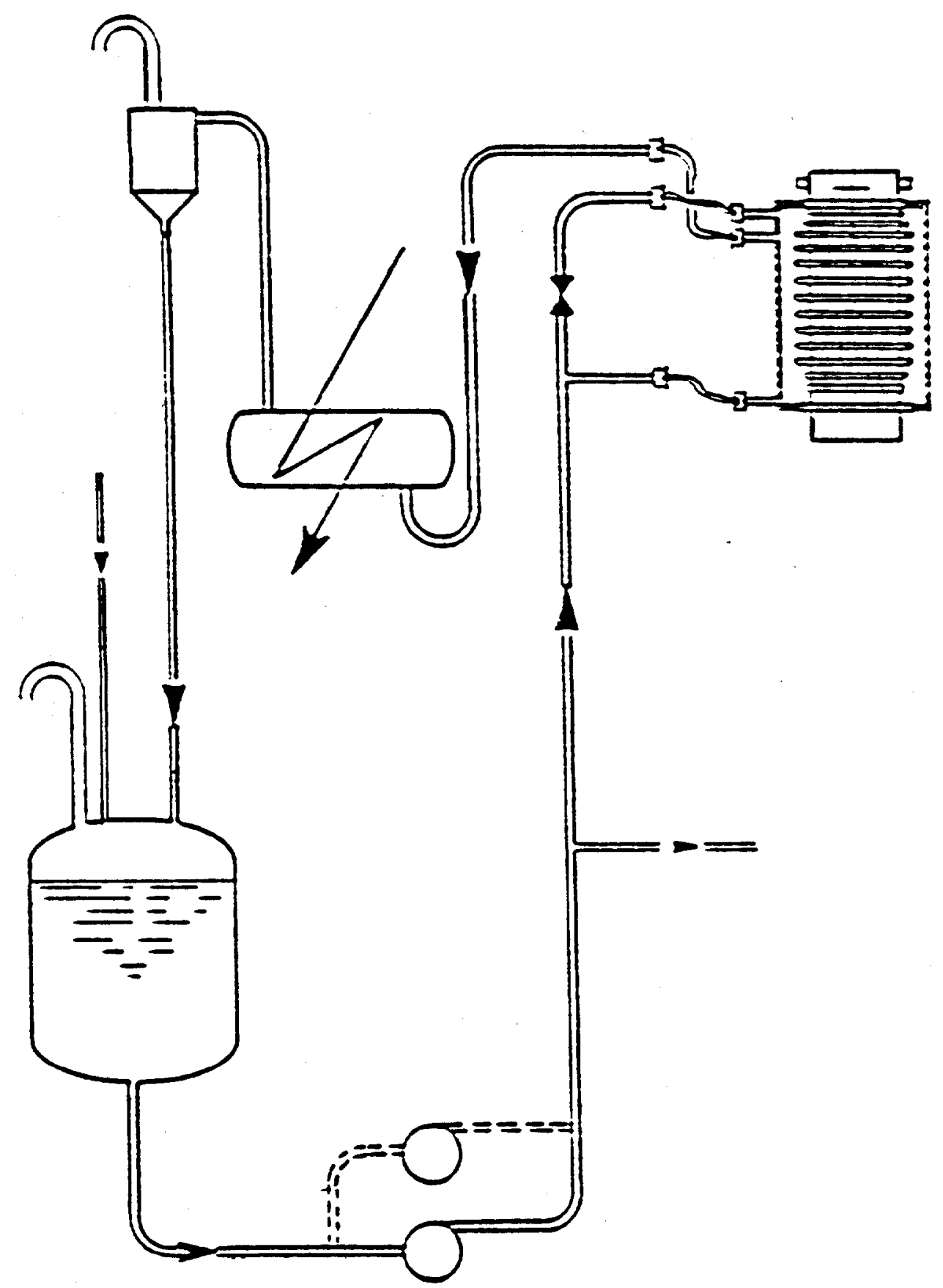

Fig. 2.6. Cask external cooling system (courtesy of SGN). 


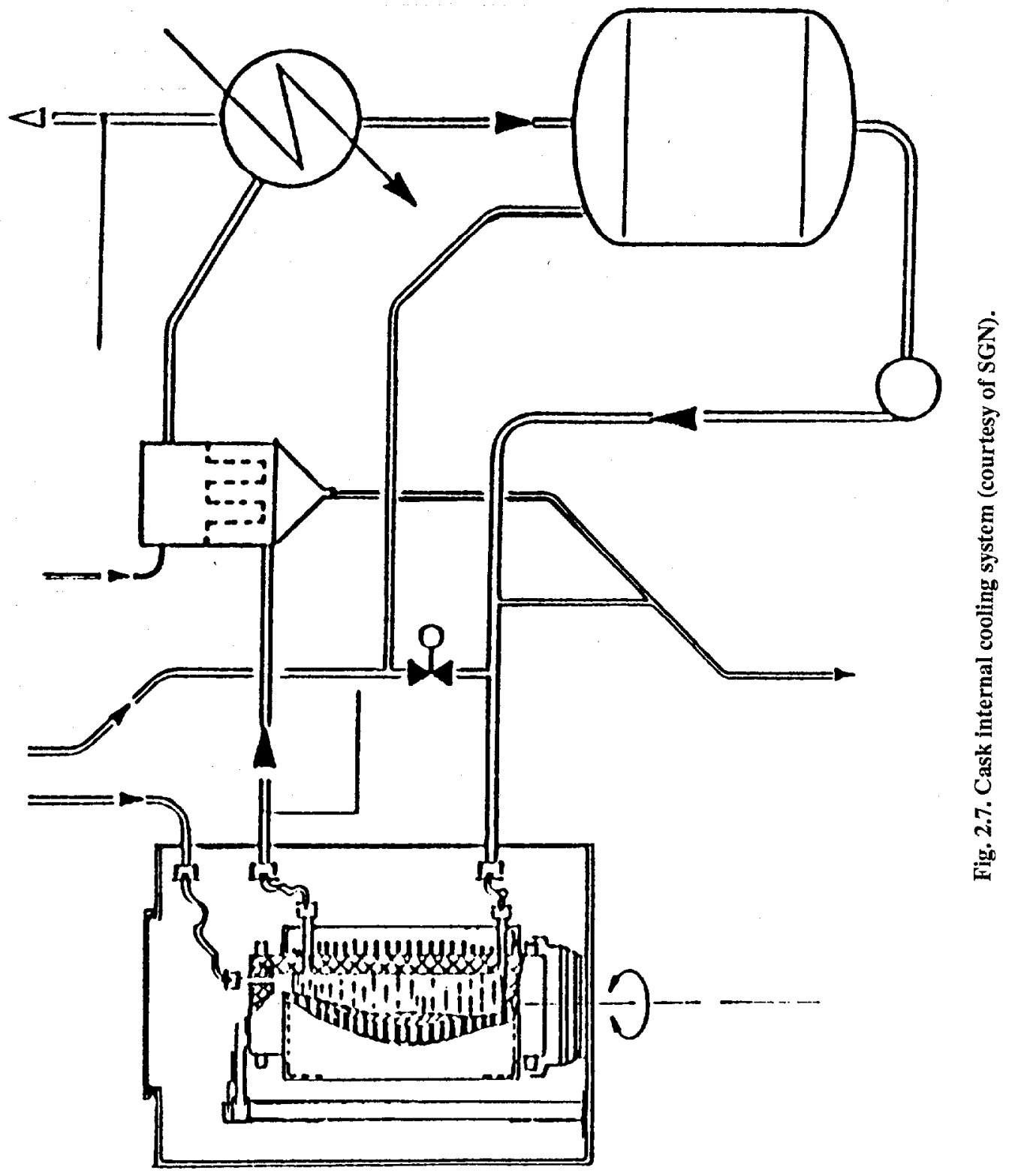


Transport casks enter the receiving cell on a trolley that is positioned on a rotating plate. The rotating plate increases the availability of the receiving area since a fully loaded cask can be stored in this area while an unloaded cask is shipped out. The necessary inspection, radiation monitoring, and contamination monitoring are performed in the receiving and shipping area.

Impact absorbers, weather covers, and other cask shipping equipment are removed using the overhead crane in the cask preparation cell. A 130-ton bridge crane is used to raise the cask onto a self-propelled dolly, after which the following operations are performed:

1. inspection of the cask closures,

2. monitoring of the internal atmosphere of the cask cavity using special containment tools,

3. detection of damaged fuel elements by a Kr-85 counting method in the cask cavity,

4. removal of the cask cover and unscrewing of the cask plug, and

5. installation of the devices used for connection of the cask with the unloading cell.

After completion of the inspection, the cask is transferred into the fuel unloading bay below the unloading cell access port. Connection between the internal cavity of the cask and the unloading cell is made by means of a proprietary connecting device which provides containment while limiting surface contamination. The containment of the cell and cask cavity is provided by the connecting device and the cask itself. This connecting device is adaptable for use with a wide variety of casks.

When the cask has been positioned under the unloading port, a mechanical closure device is lowered from the cell and is connected to the cask, so that only the top of the cask is exposed to the environment of the unloading cell. The cask plug is removed by a manipulator and stored inside the cell. A special system ensures that the upper face of the plug remains clean during all unloading operations. After the cask is opened, the BWR or PWR spent fuel assemblies are removed from the cask with a remotely-controlled fuel handling crane. The integrity of each fuel assembly is checked before being transferred to lag storage.

When the unloading operations have been completed, the cask seals and plug are replaced and the cask cavity is rinsed and dried using a vacuum pump and a cold trap. Monitoring of the radiation and contamination levels of the cask is performed before the cask is loaded onto its carrier.

The cask maintenance cell that is associated with the receiving and unloading facility is used to perform various operations, including modification of cask internal structures, lid seal replacement, etc. All the operations conducted in this maintenance unit are performed remotely.

The facility is designed to provide a fast turnaround of the shipping casks after receipt. The four main work stations (shipping and receiving area, preparation before unloading, unloading area, and preparation after unloading) are located around the rotating plate where casks are transferred on three self-propelled dollies. A singlc unloading bay can unload 1400 tU/year. Pathways of casks have been carefully analyzed both to maximize the utilization and the throughput of the facility as well as to minimize facility size.

The facility is also designed to minimize the total radiation dose rate to operating personnel through fully automated operations, remote control features, and modular remote maintenance of equipment. Cask movements in the facility are carried out from the centralized control room. The 
cask transfer dolly, the rotaling plate, and the air lock entry and exit doors are driven by a programmable controller. Unloading of fuel assemblies and their transfer to the storage area is also performed from the centralized control room. The characteristics of each cask to be processed is input to the automated production management control system which passes all of the necessary data (i.e., fuel arrangement in the cask, type of fuel assemblies, type of canisters, etc.) to the fuel handling crane robot. The operator in the control room controls the transfer of the dollies and the cask unloading cycles (cask positioning in the unloading bay, cask opening, fuel assembly unloading, transfer of assemblies to storage, and monitoring of the empty cask).

The facility requires a total of 16 persons to operate it over a 24 -h period ( 3 shifts averaging $5+$ operators/shift). Of the total, 6 operators are located in the control room and 10 operators are located throughout the facility. The facility features several items of advanced equipment designs such as the following:

1. A leak-tight connecting device between the cask and the dry unloading cell that allows the cask to be opened without contaminating the external surface of the cask or the plug. An R\&D program has been conducted since 1979 to solve the problem of containment of the fuel assemblies before and during dry unloading. A full scale mock-up was constructed to study the deposition of radioactive particulates in the dry connecting system. It features a hatch cover valve plug, which is a floating slab. This system allows the operator freedom from limits imposed by geometrical and positioning tolerances. The system tolerates a horizontal slope of $0.5 \mathrm{~cm} / \mathrm{m}$, a change in radial position of $5.6 \mathrm{~cm}$, and height variances up to $6.6 \mathrm{~cm}$.

2. A remotely-operated, stainless-steel-lined spent fuel handling crane. This crane is able to record two cask cavity coordinates in order to adapt itself to the fuel element configuration. This orientation enables the fuel elements to be gripped inside the cask and allows the camera to read the fuel element identification number. The camera can also probe the empty cask once the fuel assemblies have been unloaded. Special grippers can be adapted to grasp all types of fuel assemblies, and the crane is fitted with safety sensors such as limit switches, proximity detectors, and dynamometric weight indicators. The crane is capable of an accuracy of about $\pm 0.2 \mathrm{~cm}$ in the $\mathrm{x}$ and $\mathrm{y}$ axes. It is seismically designed and is operated through a programmable controller.

Figure 2.8 illustrates the operations involved in cask handling at the dry receiving/unloading facility, Fig. 2.9 shows a model of the dry receiving/unloading facility, Fig. 2.10 shows a model of the cask preparation cell, Fig. 2.11 shows a cask being raised to the vertical position onto a self-propelled dolly, and Fig. 2.12 shows a cask on the self-propelled dolly being mated with the unloading cell.

\subsection{SPENT FUEL STORAGE POOLS $3,7,9-11$}

\subsubsection{Pool Projects}

Storage of spent fucl in water pools has been and remains the principal method of storing spent fuel assemblies in both Britain and France. French storage pool design is quite sophisticated by comparison with the usual U.S. designs. Some of the differences are necessary as a result of the larger capacity of the La Hague plant storage pools - upwards of $2000 \mathrm{tU}$ each. To 


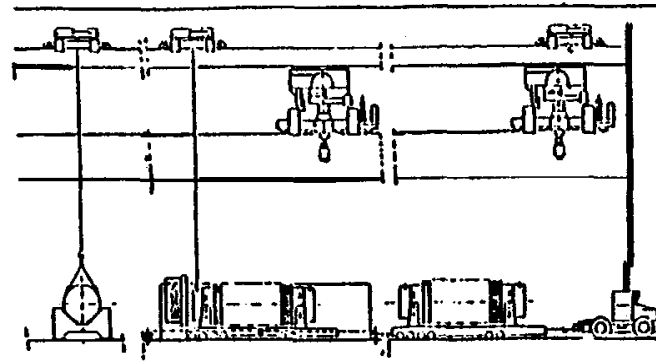

REMOVAL OF PROTECTIVE COVER

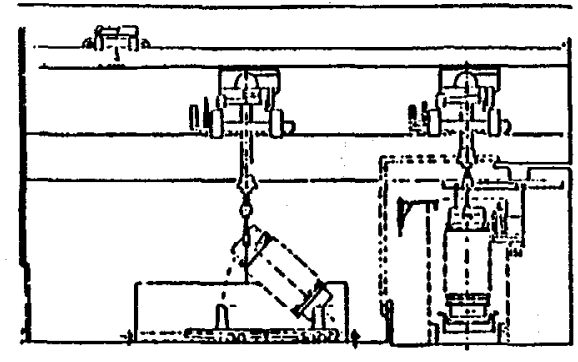

REMOTE UPRIGHTING OF CASK

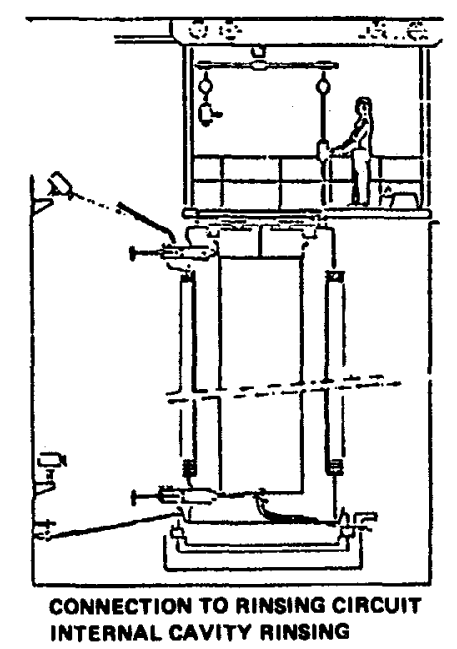

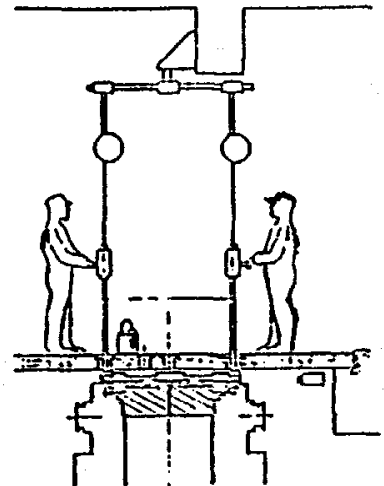

REMOVAL OF LIO SCREWS FTERNAL ATMOSPHERE CHECK OF CASK THIGHTNESS

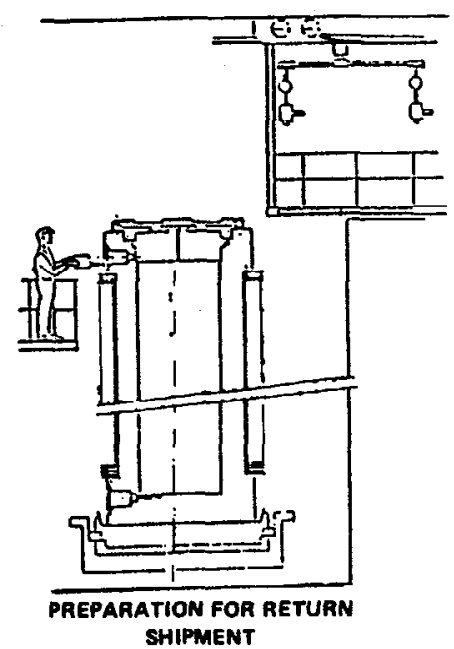

Fig. 2.8. Cask handling operations at dry unloading facility (courtesy of SGN). 


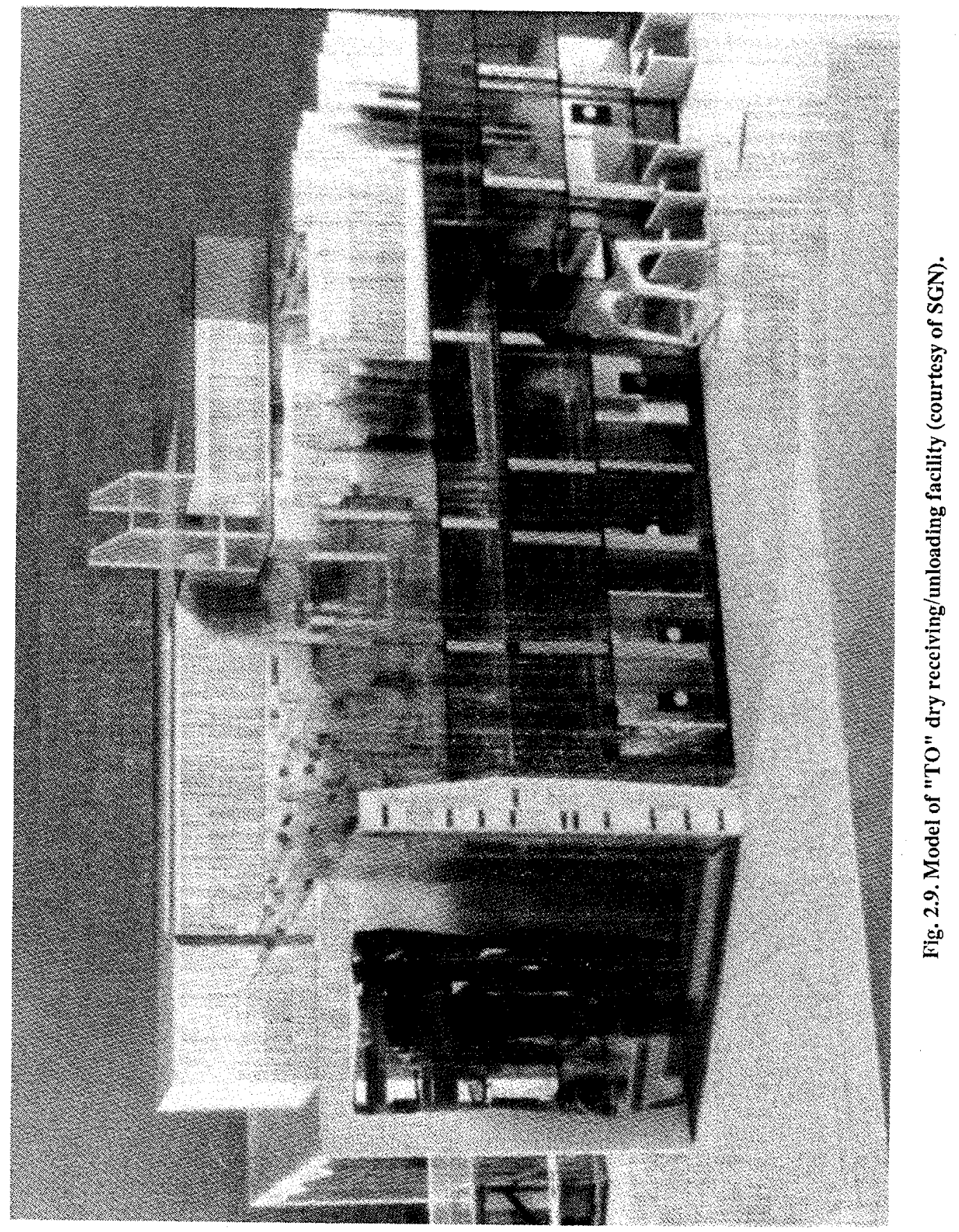




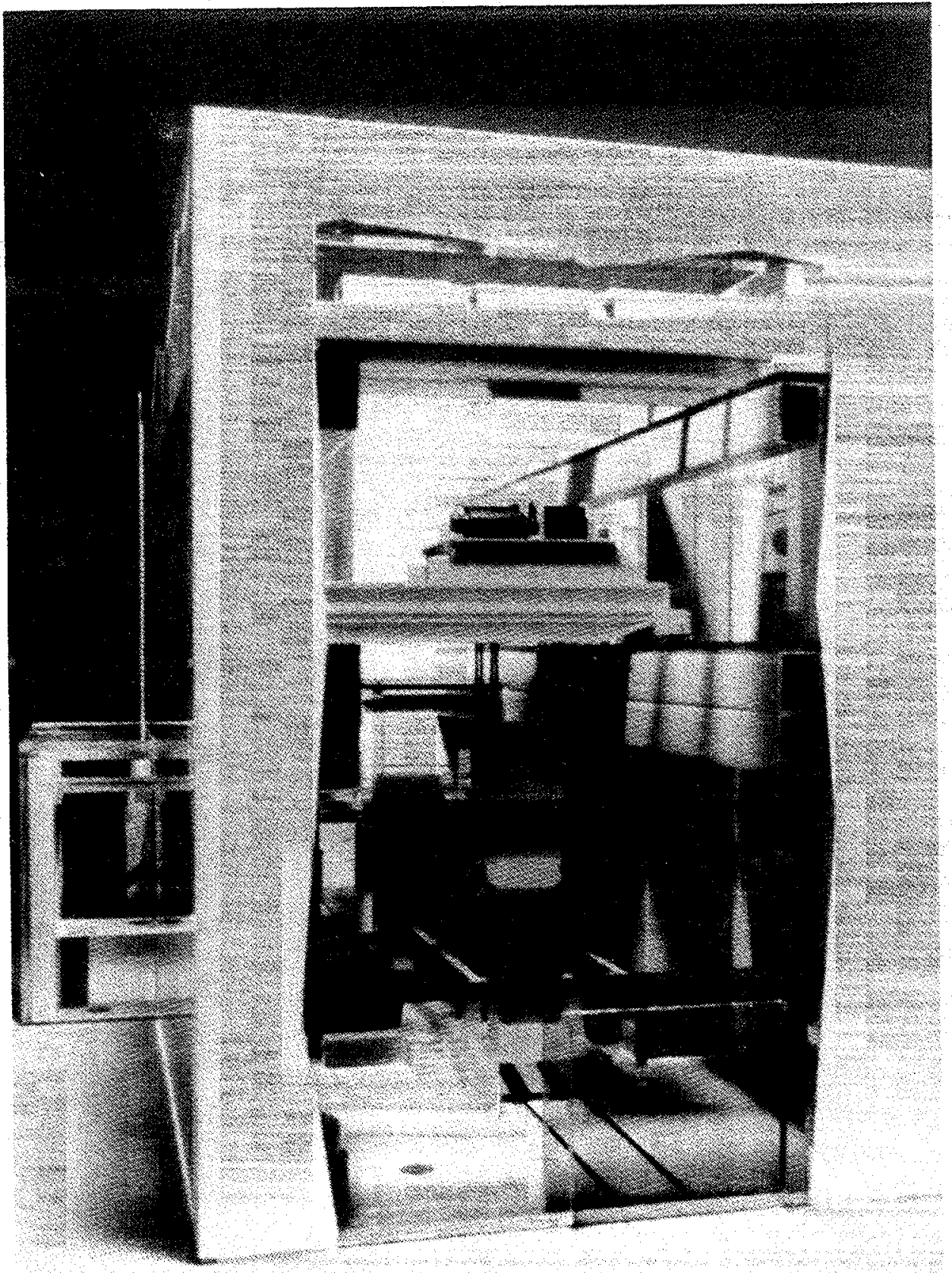




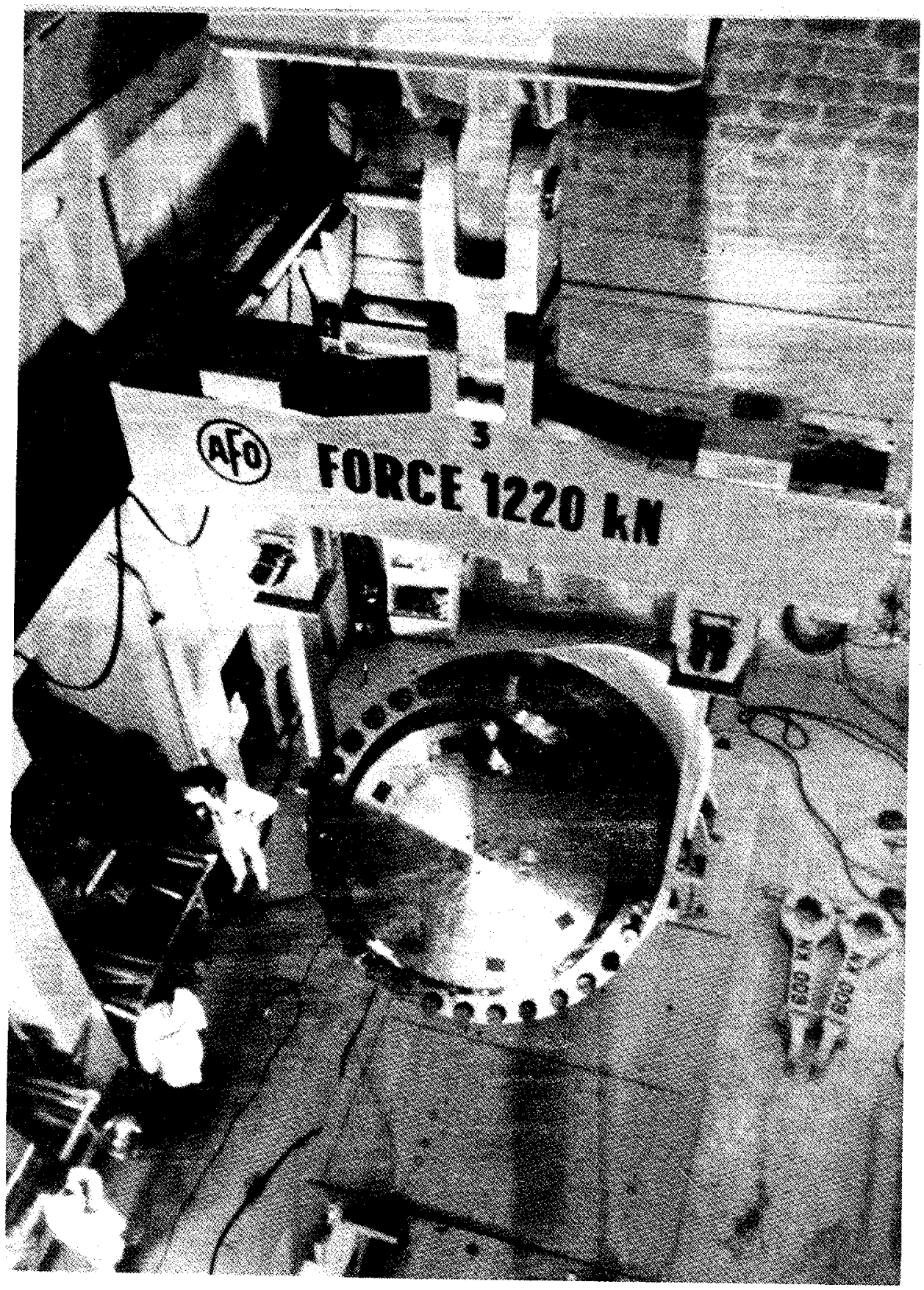

Fig. 2.11. Raising the spent fuel cask into a self-propelled dolly (courtesy of SGN). 


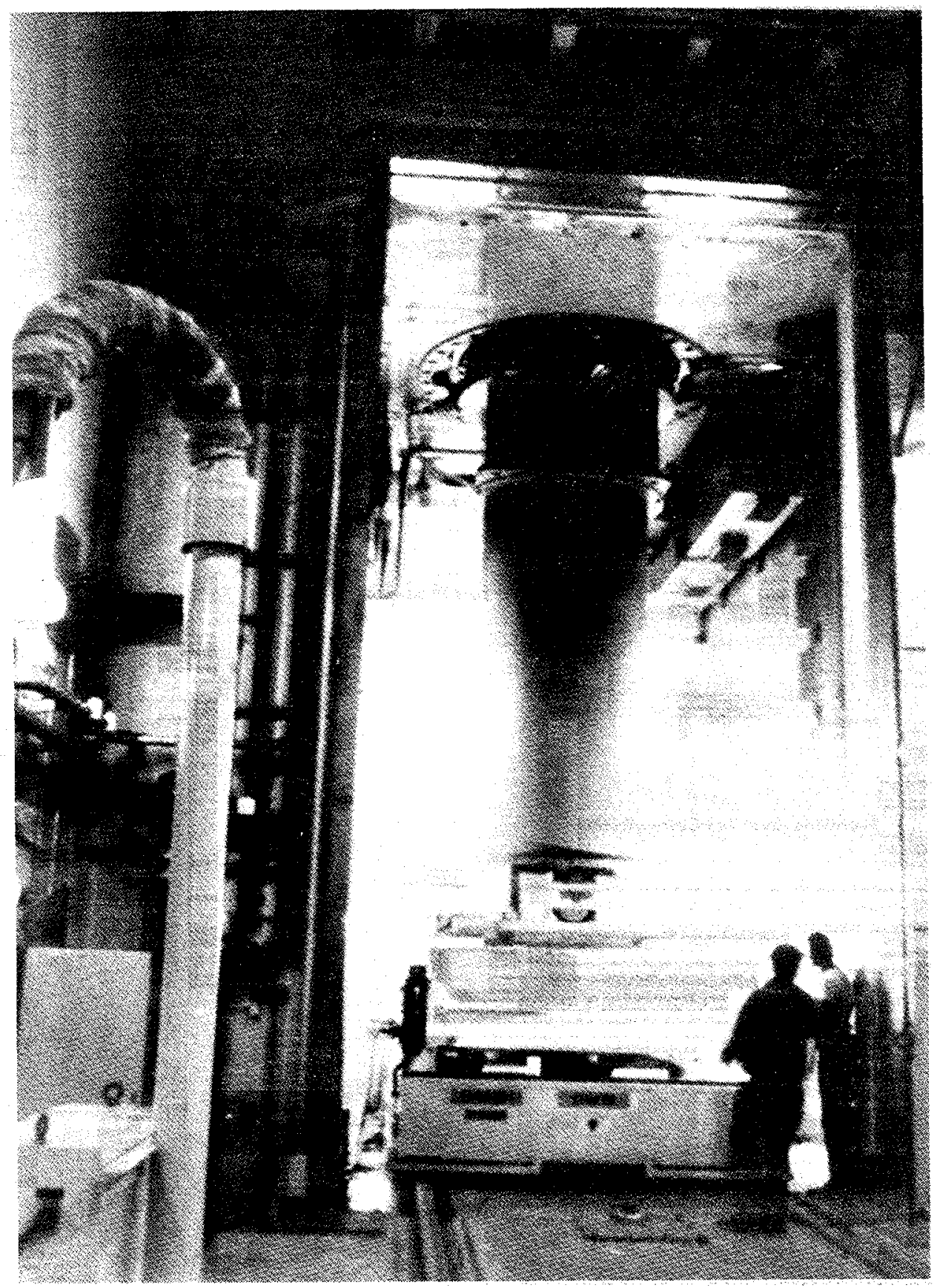

Fig. 2.12. Mating of a cask with unloading cell (courtesy of SGN). 
accommodate thermal expansion, for example, the water pool itself is isolated from the rest of the structure and rests on a series of large neoprene blocks which can be replaced while the pool is in service (viscoelastic supports). This method of construction is also reported to attenuate the impact of an earthquake on the storage pool. Process lines carrying potentially contaminated water are shielded, and the circulating pumps are positioned in shielded niches. The new water pools at La Hague are fully automated in that once a fuel assembly has been introduced into the pool it is moved to its storage location in a fully remotely controlled operation, and it may be retrieved in the same fashion.

The principal fuel receiving and pool storage facility for the UP2-800 and UP3 reprocessing facilities at La Hague is an example of a fully integrated system which incorporates a range of technologies that have been developed by the French. The facility is outlined diagrammatically in Fig. 2.13, with the cask storage facility (AML) shown in the background. The casks can be either wet-loaded in the NPH facility (upper left) or dry-unloaded in the TO facility (lower right). While the UP2-800 reprocessing facility is fed from the NPH facility and the UP3 plant is fed from D and E Ponds (lower center), fuel can be transferred between the various ponds and the NPH so that fuel stored anywhere in this system can be introduced to either reprocessing facility.

The NPH facility has been in operation since 1981 and has a nominal capacity of $2000 \mathrm{tU}$. It is equipped with two separate cask unloading lines which have a combined capability to receive and unload 100-200 transport casks annually. A cask maintenance shop is associated with the facility for changing internal structures, replacement of lid gaskets, washing of the internal cavity of the cask, and like activities. Most operations in this shop are performed remotely. The facility also contains a cell for preparation of casks having thermal power releases up to $85 \mathrm{~kW}$. The storage pools are designed to prevent pool damage resulting from the drop of a 130-ton cask. All equipment items (valves, pumps, and filters) installed in the NPH circuits that convey fluids having radioactivity levels greater than $5 \times 10^{-5} \mathrm{Ci} / \mathrm{L}$ are capable of being maintained remotely. LWR fuel assemblies are placed in baskets capable of holding 9 PWR or $16 \mathrm{BWR}$ assemblies. The pool has a capability for storing 560 such baskets, although this could be increased to 700 baskets if a more compact basket configuration were used. Figure 2.14 shows the cask unloading pool, Fig. 2.15 shows the NPH storage pools, and Fig. 2.16 shows the schematic flow of fuel in the NPH facility.

The C-Pool has been in operation since 1984 and also has a nominal capability of $2000 \mathrm{tU}$. There is a transfer system for moving baskets between the NPH facility cask unloading pool and the C-Pool along an inverted "V" path with $55^{\circ}$ slopes on both sides. Basket transfer between the D-Pool and C-Pool is effected by an underwater transfer dolly. The C-Pool is about $30 \mathrm{~m}$ long, $24 \mathrm{~m}$ wide, and $10 \mathrm{~m}$ deep, and is in a single structure which rests on two rows of viscoelastic supports. Water cooling and water cleanup is effected in submerged units attached to the walls of the pool (see Sect. 2.5.2). The transfer of fuel baskets in the pool is accomplished using a remotely operated jib crane. Figure 2.17 shows a pole crane for underwater handling of spent fuel storage baskets, and Fig. 2.18 shows the C-Pond and the crane used for remote handling of spent fuel baskets.

Based on its experience in water pool storage facilities, SGN was selected to design and supervise startup of the spent fuel receiving and handling facility at the CLAB (see Sect. 3.3 for a discussion of the CLAB). 


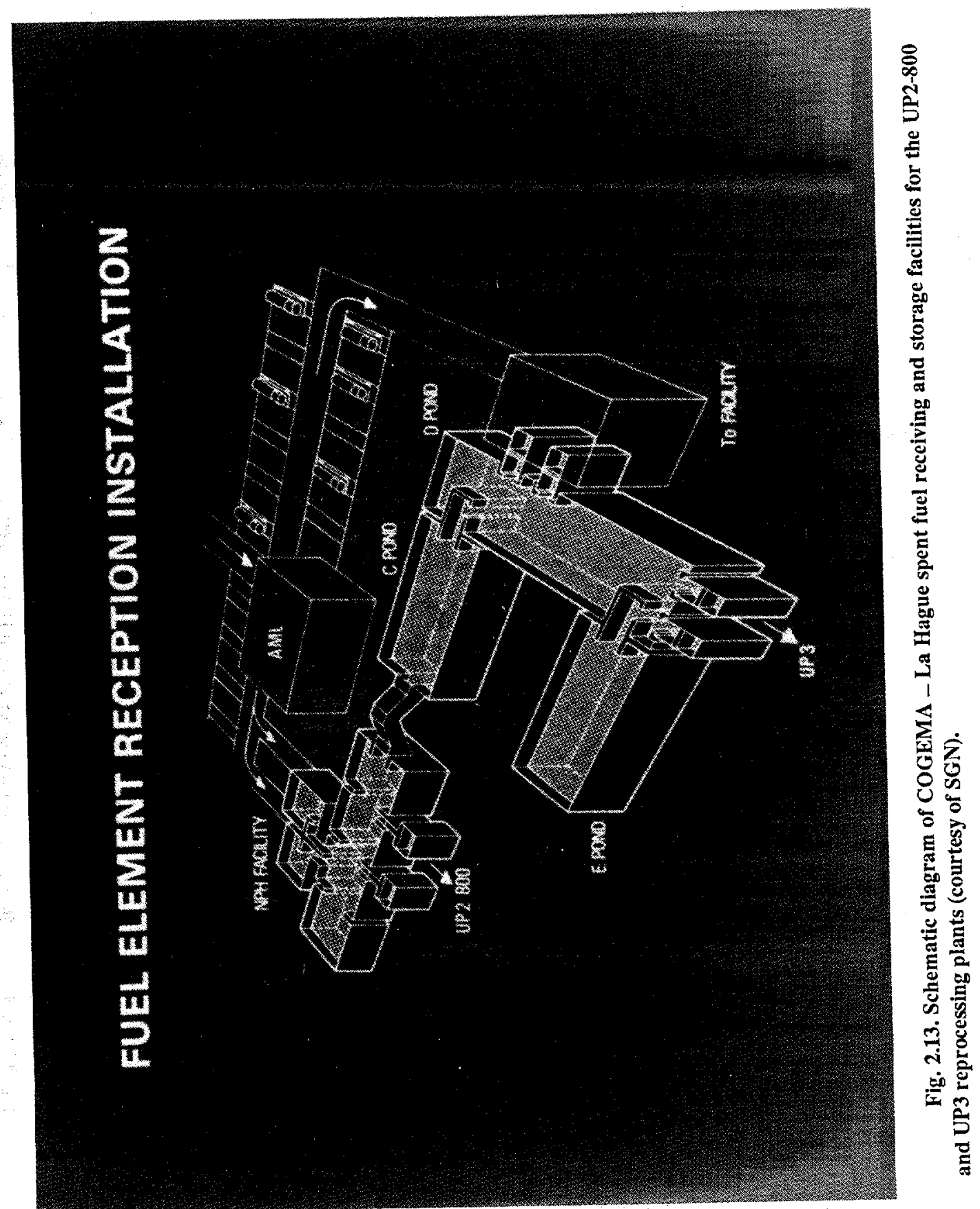




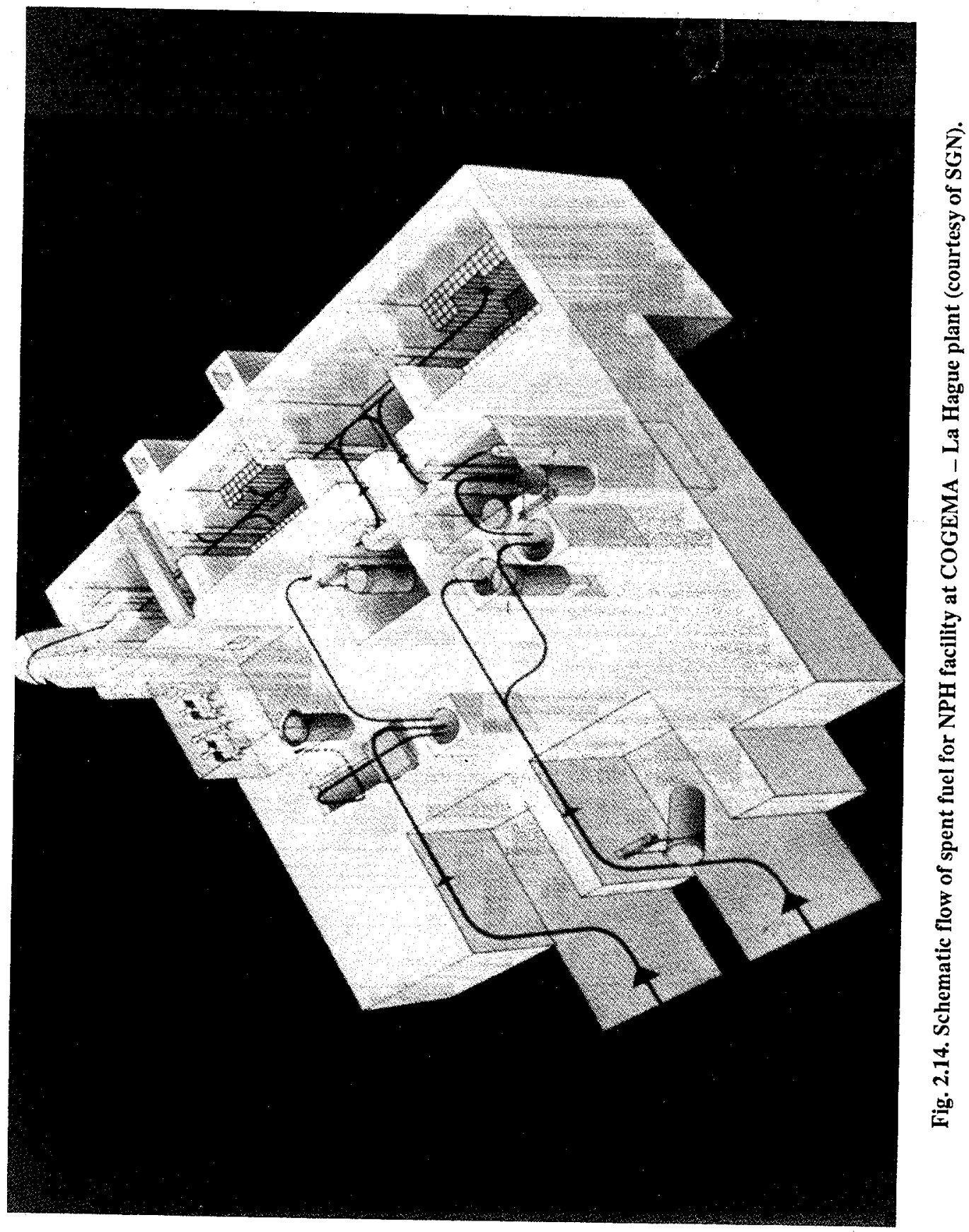




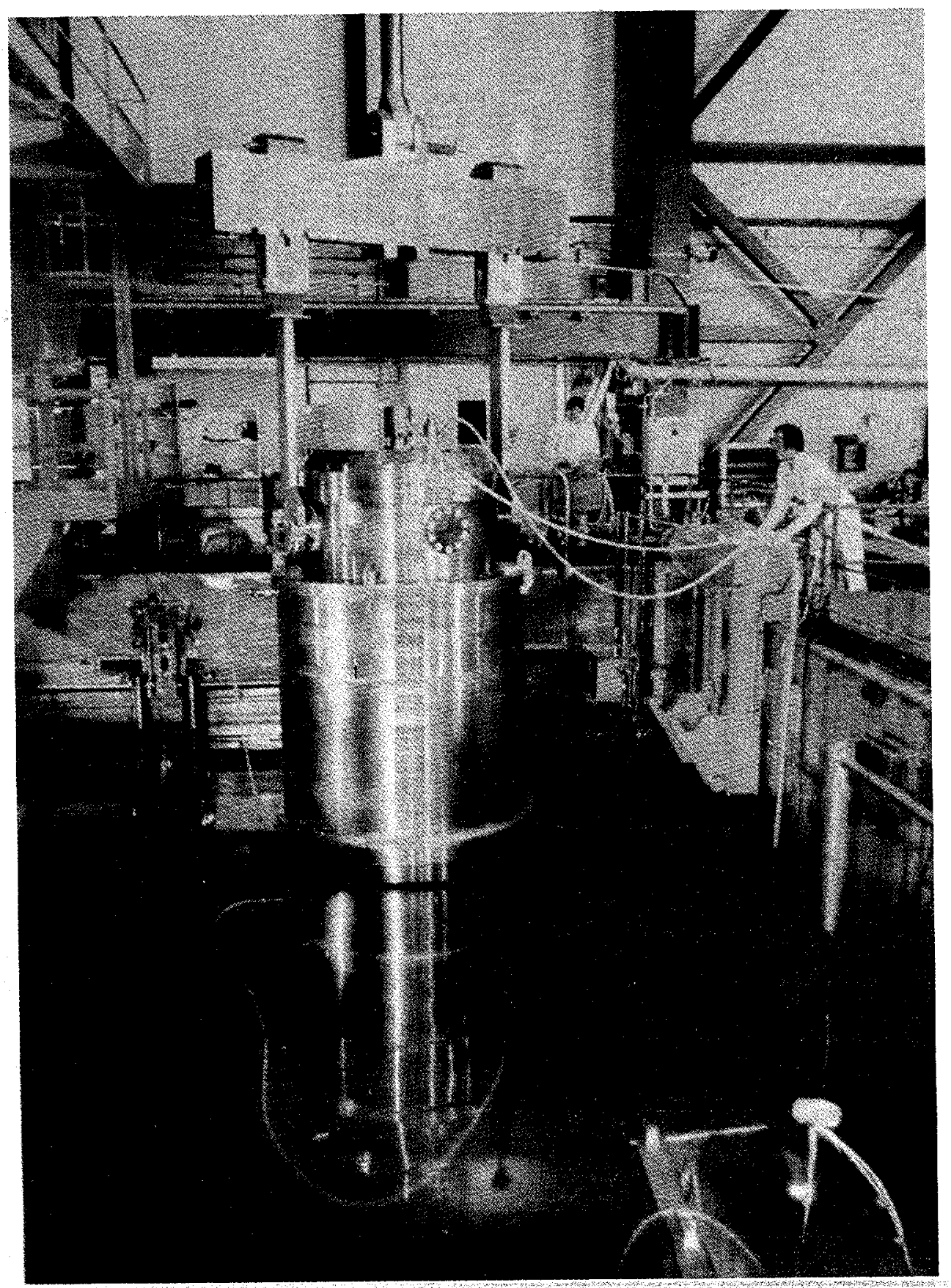

Fig. 2.15. NPH facility cask unloading pool at COGEMA - La Hague Plant (courtesy of SGN). 


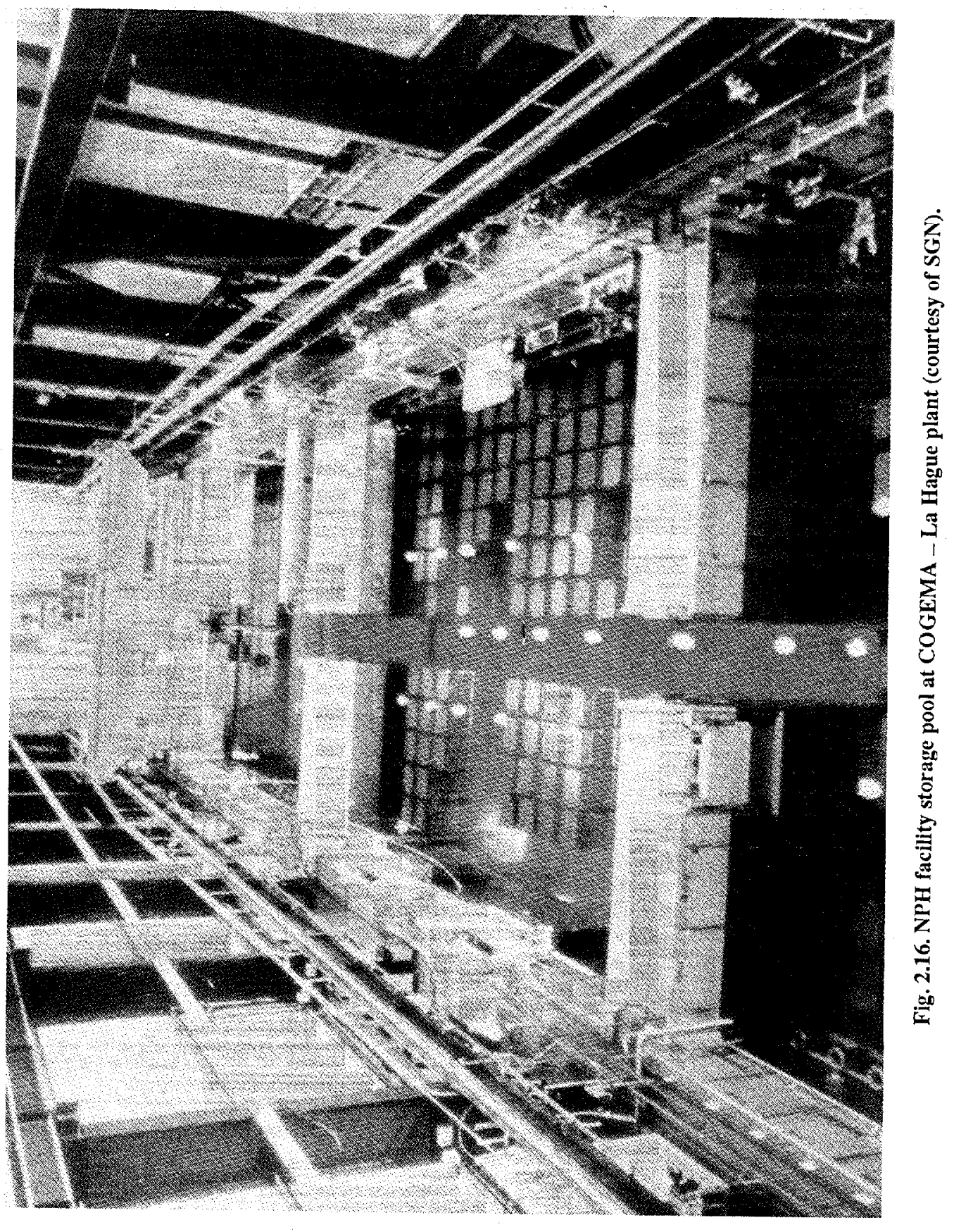




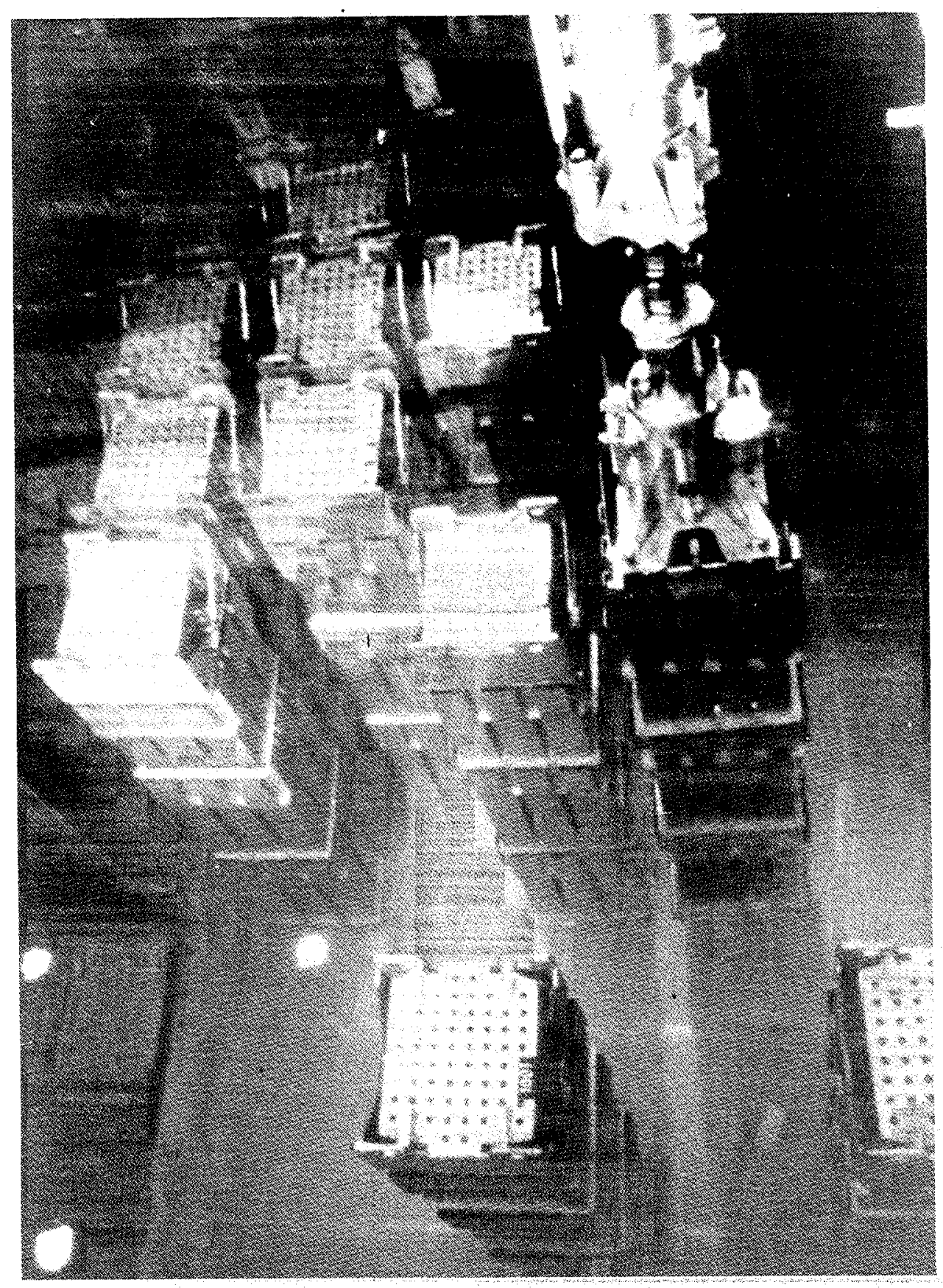

Fig. 2.17. Pole crane for underwater handling of spent fuel storage baskets at COGEMA - La Hague plant (courtesy of SGN). 


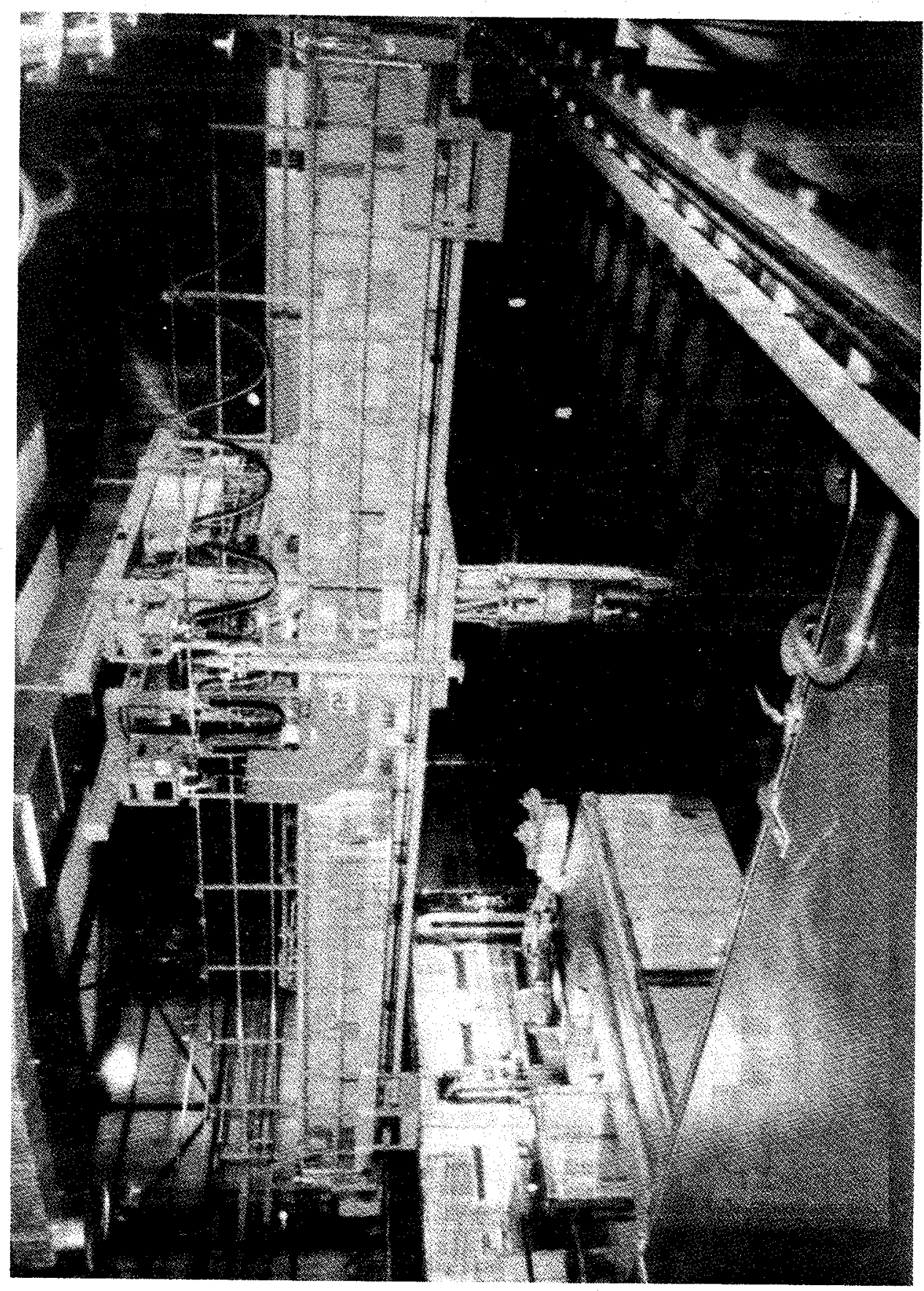

客 


\subsubsection{Auxiliary Equipment}

During the course of its design and use of pools in France for spent fuel storage, COGEMA-SGN has developed unique designs for auxiliary equipment, including shock absorbing pads, heat exchangers, and pool cleaning equipment. The following sections describe this equipment.

\subsubsection{Shock absorbing pads for spent fuel unloading pools}

A special shock absorbing pad has been developed for installation on the bottom of a cask unloading pool to protect it against the impact resulting from an accidental drop of a spent fuel cask or baskets. The pad consists of a series of metal tubes welded to two plates. The lower plate rests on the bottom of the pool, and the upper plate is used to support the cask in the pool and to absorb impacts. The pads are designed to safely decelerate a 130-ton cask falling from a height of $16 \mathrm{~m} \mathrm{(2} \mathrm{m}$ in air and $14 \mathrm{~m}$ in water). The pads have undergone safety tests to demonstrate their performance. They can also decelerate a cask basket having an impact of $2930 \mathrm{~kg} / \mathrm{m}^{2}$. The pads limit the effects of the drop impact throughout the entire pool structure so that the maximum load never exceeds the structural strength of the pool. They prevent rebound of the dropped object and are designed for a fall trajectory of $10^{\circ}$. Pads are available in a range of thicknesses from 1.3 to $2.1 \mathrm{~m}$.

These pads have been used at the COGEMA-La Hague plant since 1978. A diagram of the pads in a cask unloading pool is shown in Fig. 2.19.

\subsubsection{Heat exchanger}

Usually pool water is cooled in an externally located cooling circuit. However, SGN has designed a unique heat exchanger unit (called NYMPHEA) which allows in-situ cooling of the pool water without any circulation outside the pool. Thus, there is no radiation hazard created outside of the pool itself nor danger of inadvertent drainage of the pool. Moreover, overall construction of the pool system is materially simplified.

In this concept, the heat exchanger is mounted on the inside wall of the pool. It is made up of three basic parts: (1) a frame with a water chamber cell which supports the rest of the system, (2) a tube stack (500 tubes), and (3) a motor-pump unit which is connected to the tube stack by a cone-shaped diffuser. Connection to coolant pipes is above the water level of the pool. Under normal operating conditions, the heat exchanger has a capacity for removing $1 \mathrm{MW}$ of thermal power at a constant pool water temperature of $40^{\circ} \mathrm{F}$, using $90 \mathrm{~m}^{3} / \mathrm{h}$ of cooling water at $28^{\circ} \mathrm{C}$. When the pump is off, a significant measure of cooling continues due to a thermosiphon effect. The lower frame, tube stack, and cone diffuser are constructed of 304L stainless steel. The motor pump consists of one axial impeller on a vertical shaft mounted in the tube-guide with bearings. It is equipped with direct drive by a flexible coupling with a $5-\mathrm{kW}$ motor. The unit is $7.5 \mathrm{~m}$ high (6 m immersed), has a diameter of $0.8 \mathrm{~m}$, and weighs $3000 \mathrm{~kg}$, excluding the supporting frame, and is readily disassembled using standard pool tools.

The pump drives the water from the upper part of the pool down through the tube stack and out of the base of the unit through lateral discharge openings. Figure 2.20 shows a diagram of the heat exchanger mounted in a spent fuel storage pool.

The SGN has also developed an ion exchanger unit that is similarly designed and mounted inside the pool, which together with the heat exchanger completely eliminates the need for external piping. Details on this unit were not available and therefore have not been included in this report. 


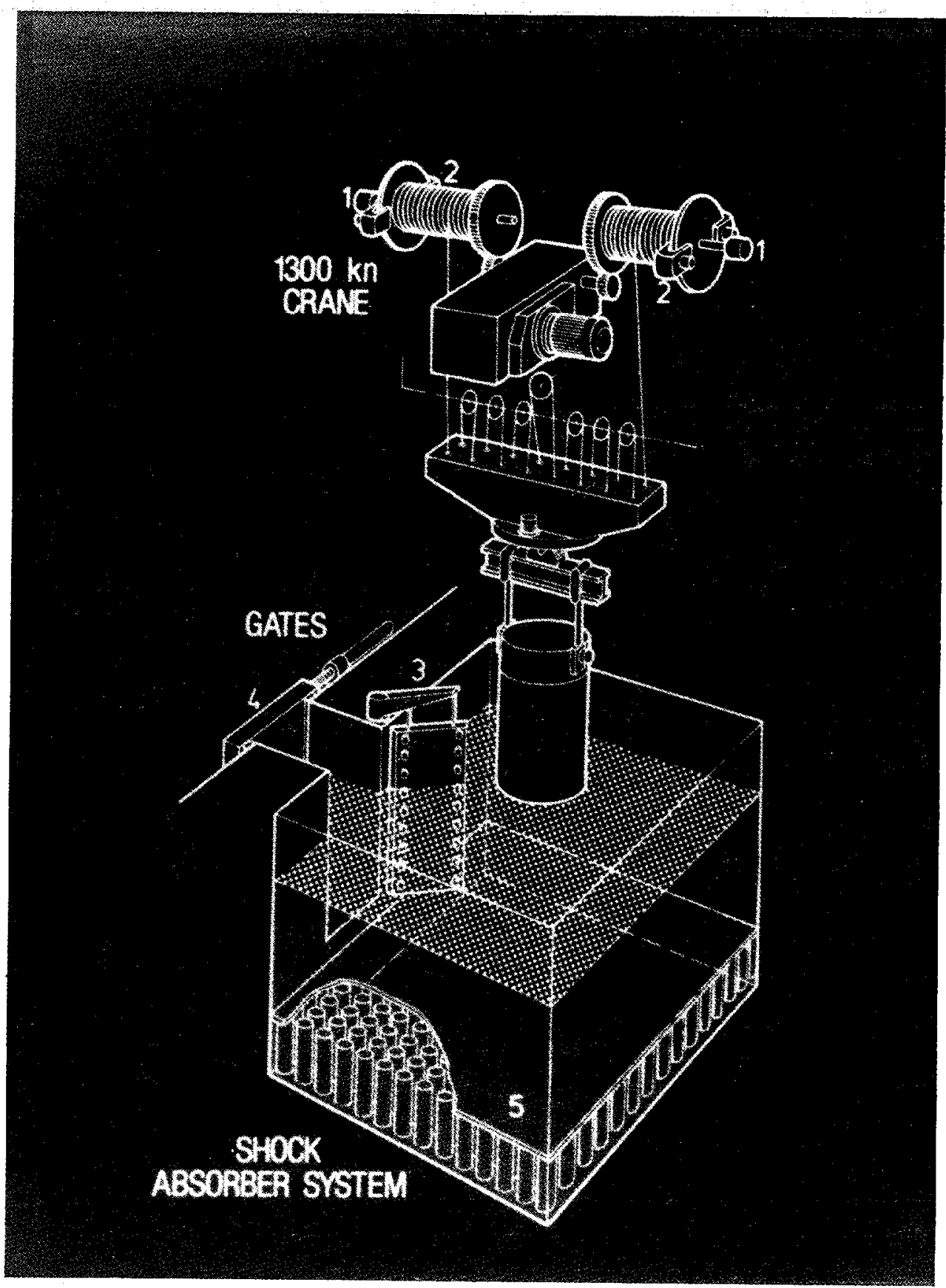

Fig. 2.19. Pool shock absorber pads (courtesy of SGN). 


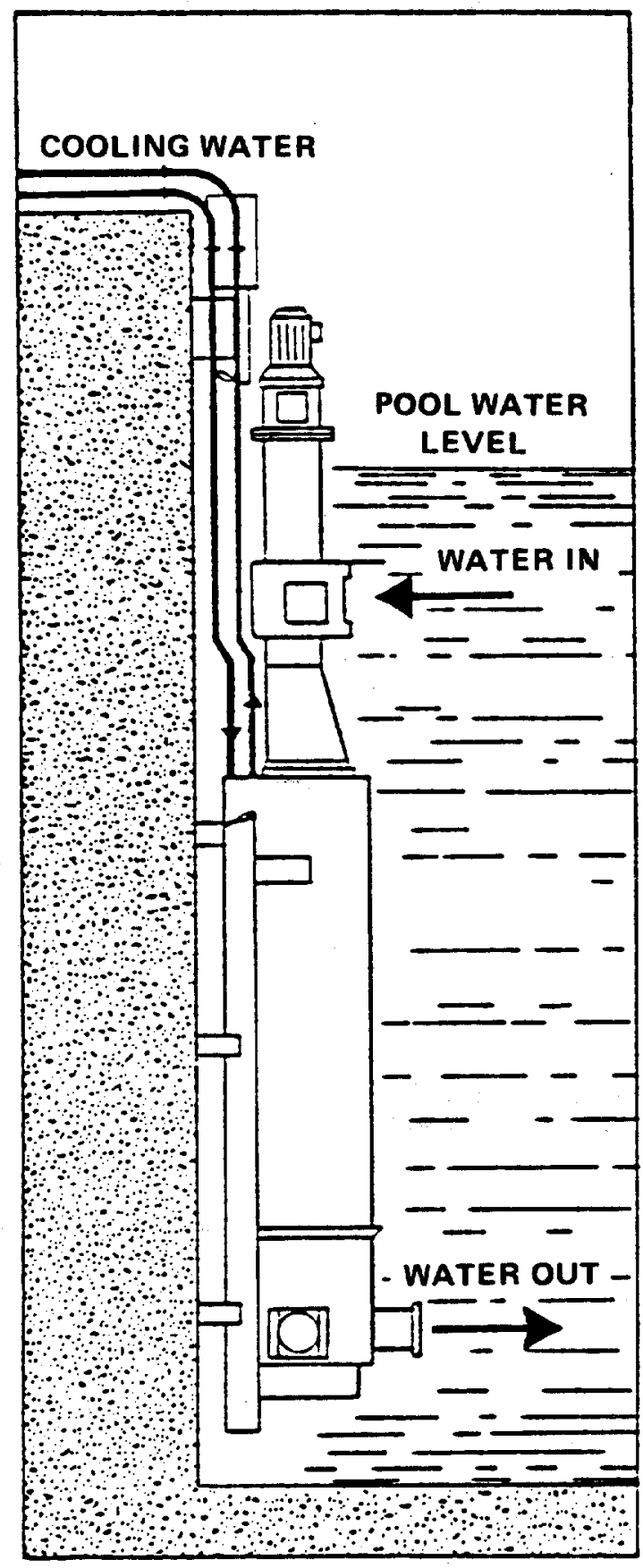

Fig. 2.20. Heat exchanger for spent fuel storage pool (courtesy of SGN). 


\subsubsection{Pool bottom cleaning equipment}

The SGN has developed a system for cleaning the bottom of spent fuel pools and removing the sludge deposited there that consists of dust, deposits from the fuel cladding, spent fuel particles, resins, and fibers. The cleaning equipment consists of (1) a $4-\mathrm{kW}$ vacuuming device consisting of an immersed pump and particle separator cyclone collector, (2) a filtration unit consisting of a 4-mm mesh inlet filter, a receiving container, and a 100-micron outlet filter, and (3) a 50-cm-wide suction nozzle which moves along the pool bottom on a track at a velocity of $3 \mathrm{~m} / \mathrm{min}$. The vacuum motor is mounted on the nozzle carrier. All immersed parts of the system are constructed of stainless steel, except the vacuum hose.

Sludge is vacuumed through the nozzle into a cotton filter, then into a cyclone collector, and finally into an outlet filter which removes the remaining light particles. Replacement of filters and collectors is achieved by their removal to the pool surface where they are placed in shielded containers using standard pool tools. The reverse process is used to install new filters and collectors. When not in use, the cleaning equipment is placed on a rack mounted on the pool wall.

This type of unit is currently in use in the COGEMA-La Hague plant. Figure 2.21 shows a diagram of this system.

\subsection{SPENT FUEL STORAGE VAULTS}

The British and French have developed and are now using dry storage facilities for spent fuel and high-level radioactive solids. The following sections describe some of these facilities.

\subsubsection{British Vault Storage Designs ${ }^{12 \cdot 17}$}

The British are using the GEC Energy Systems modular dry storage facilities for spent fuel at the Wylfa nuclear station and may be planning to extend their dry storage techniques to other U.K. stations. In addition, several years ago they prepared a conceptual design of facilities for storage of spent fuel for the Tennessee Valley Authority (TVA). Several of the British dry vault storage designs and facilities are described below.

\subsubsection{Modular Vault Dry Storage (MVDS) Concept}

The basic concept of the GEC Energy Systems MVDS concept (Fig. 2.22) consists of banks of closed, carbon steel tubes which contain the stored fuel assemblies. Each tube holds three stacked, advanced gas-cooled reactor (AGR) fuel assemblies or one PWR assembly.

The storage tubes are sealed at the bottom by a welded plug and at their upper ends by a removable shield plug with double elastomeric O-rings. Each of the tubes is connected by small diameter tubing to a central monitoring, filtering, and exhaust system. In normal operation, an exhaust blower maintains a constant negative pressure in the storage tubes. In the event of a leak in the storage tube, the air flow is always into the tube, and the monitoring system will detect this leak and initiate an appropriate alarm. The monitoring system can also detect the fission products from a leaking fuel rod. The storage tubes can also be back-charged with an inert gas if this environment is required.

If double containment of the spent fuel is required, the fuel assembly can be placed in a sealed canister, which is then placed in the storage tube.

The decay heat from the stored fuel is continuously removed by ambient air flowing over the outside of the storage tubes. The flow of cooling air is induced by the bouyancy head created by the heated air leaving the vault in the discharge duct and stack. Filtration of the discharged cooling air is not required since the cooling air is not in direct contact with the fuel. 


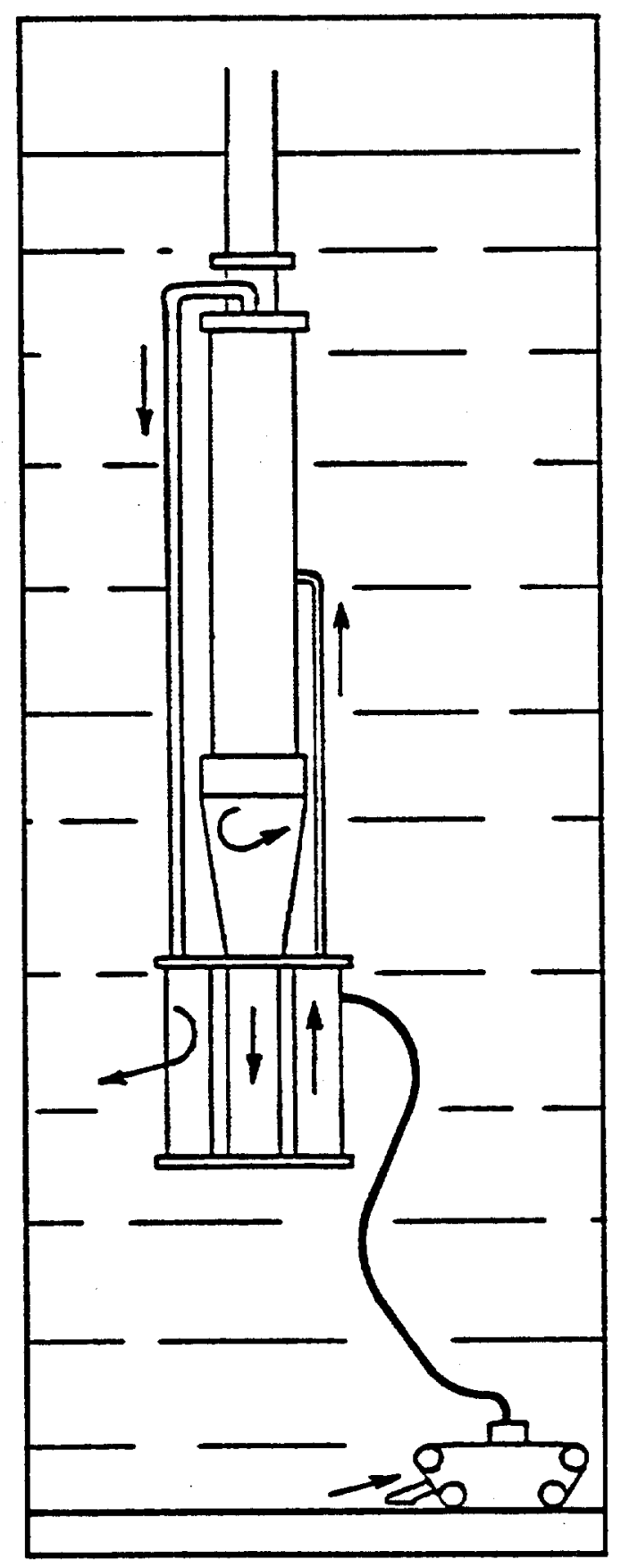

Fig. 2.21. Pool bottom cleaning equipment (courtesy of SGN). 


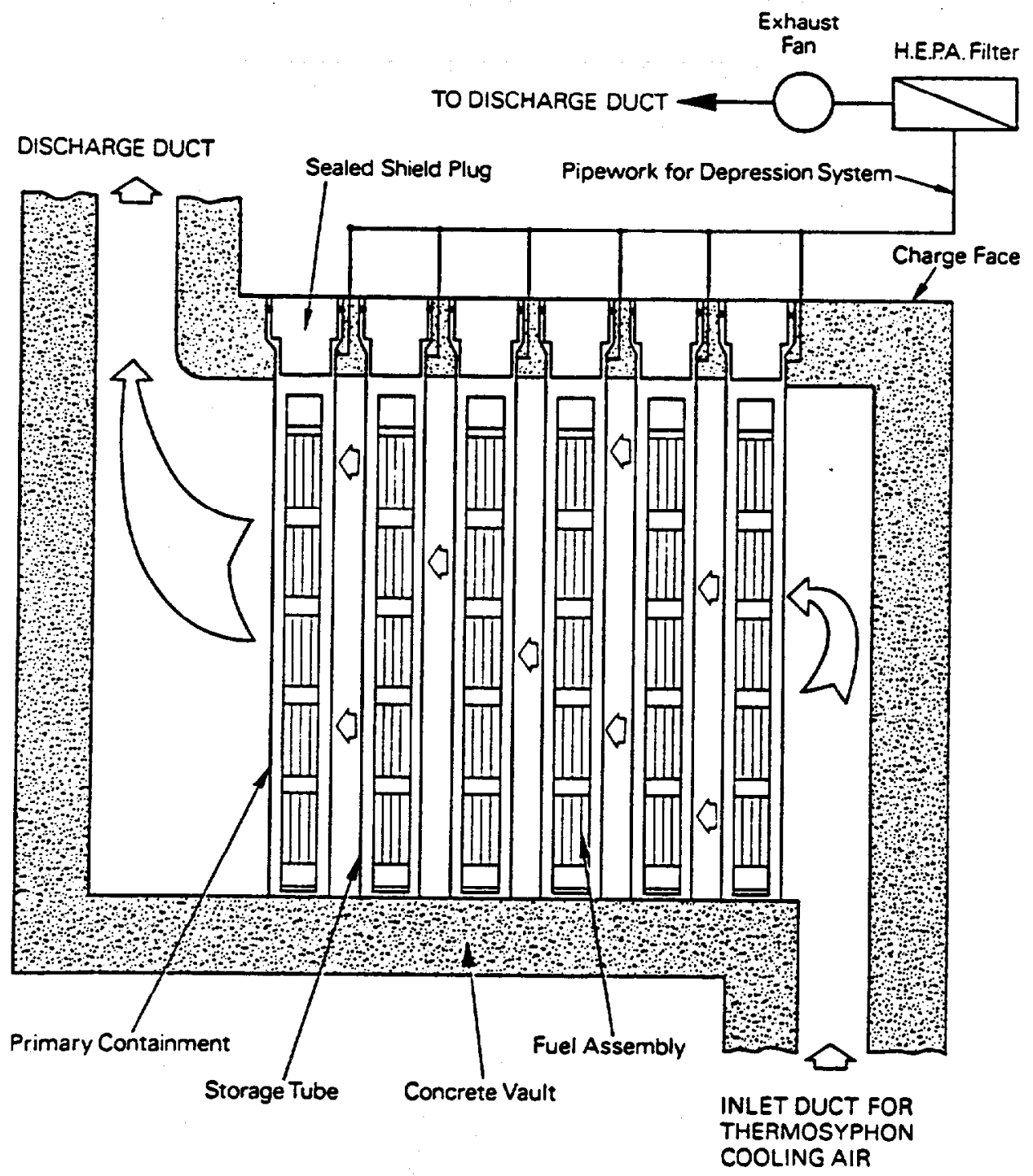

Fig. 2.22. Schematic of modular vault dry storage system (courtesy of GEC).

While Fig. 2.22 shows a horizontal cooling air flow path from one side of the vault to the other side, some MVDS designs utilize an annular flow, parallel to the axis of the storage tubes in a vertical direction. Figure 2.23 illustrates this method of cooling. Although not shown here, the storage tubes are connected to a monitoring system like that shown in Fig. 2.22.

Figure 2.24 is an architect's rendition of a complete MVDS facility, with spent fuel transport cask unloading facilities at one end and groups of storage tube banks (modules) at the other end. The modules are independent of each other and can be added as needed to increase the storage capacity of the facility. 


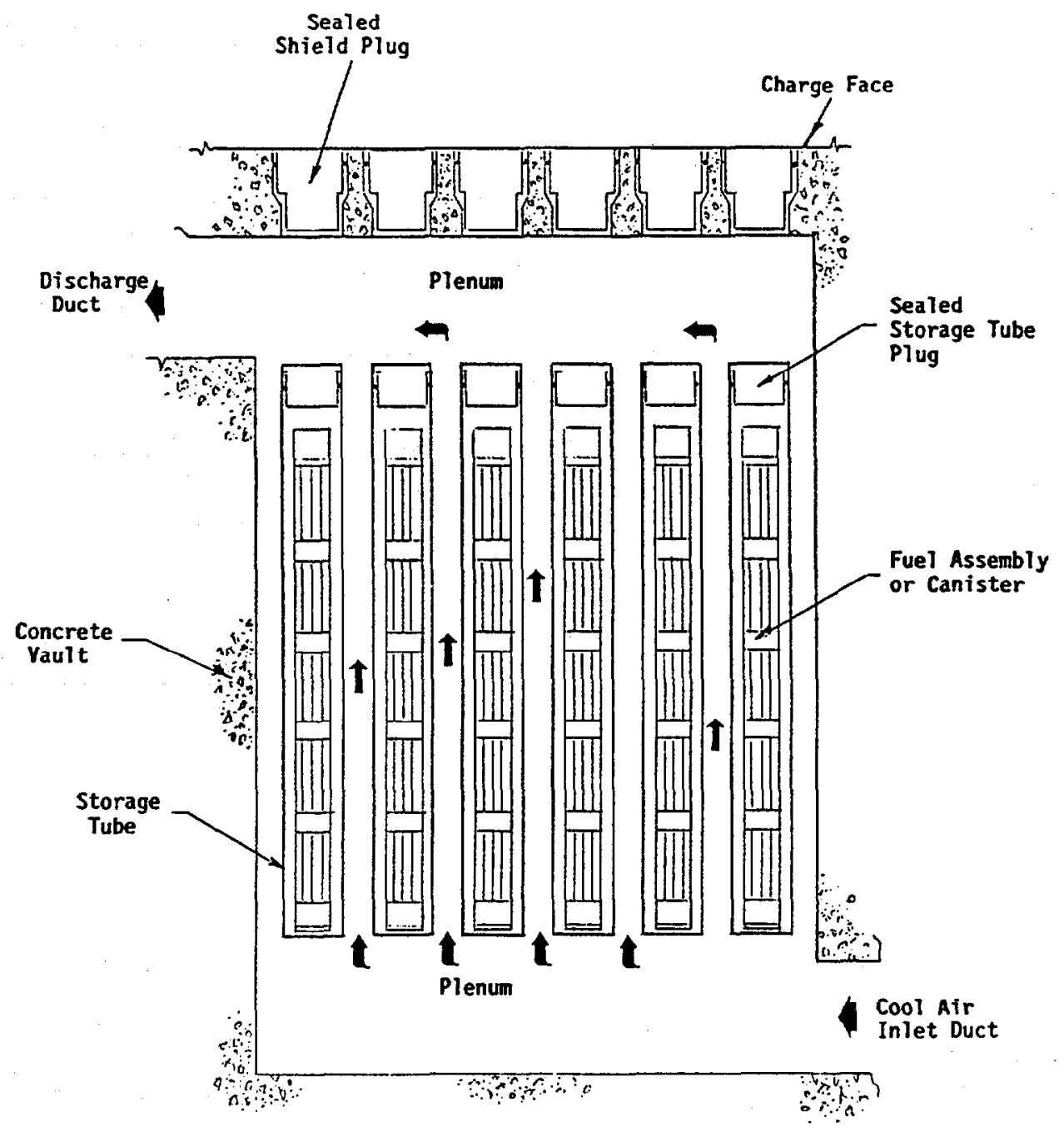

Fig. 2.23. Alternative MVDS cooling path.

\subsubsection{Wylfa dry storage system}

Figure 2.25 illustrates the Wylfa Nuclear Power Station dry storage modules (cells 1,2, and 3). This arrangement is similar to the concept shown in Fig. 2.23, except that the modules are cylindrical pressure vessels. Two additional modules (cells 4 and 5) with cross-flow cooling have been added at the Wylfa station.

The Wylfa dry storage facilities have been in operation for 17 years with MX and AGR fuel assemblies and have experienced no major problems.

\subsubsection{AGR storage facility}

Figure 2.26 shows the cross section of a large AGR fuel storage facility that has been designed. Each of its modules will hold about $210 \mathrm{tU}$ of AGR type fuel (or $600 \mathrm{tU}$ of PWR fuel). 


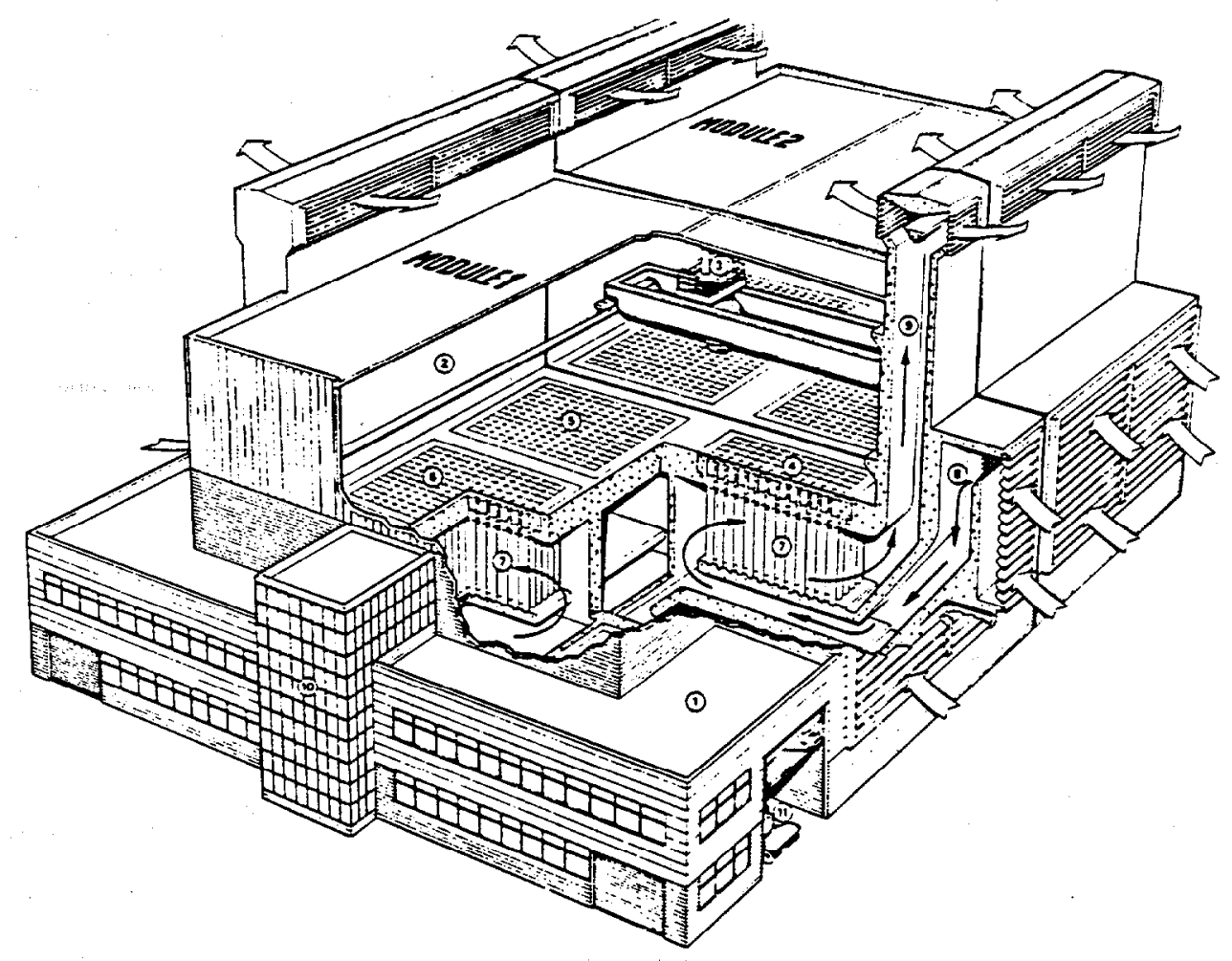

Fig. 2.24. Conceptual MVDS facility.

This facility will have the following capabilities and features:

1. Truck and rail cask unloading cells.

2. Duplicate processing lines with hot cell for fuel assembly inspection, drying, placement in canisters (4 AGR or 1 PWR assembly per canister), canister welding and inert gas filling.

3. Two rows of storage vaults extending either side of the central cask unloading and processing area. Four vaults could be built initially, and pairs of vaults added up to a total of 30 vaults (about 18,000 tU of PWR fuel).

4. The canister handling machine (one per row of vaults) is a shielded body containing a hoist and magazine carrying up to 5 canisters. It also contains the mechanism for removing and replacing the shield plugs. The machine is mounted on a bridge which spans the line of vaults, and its cross-travel enables it to reach each storage position along the row.

5. Natural draft passive air cooling of the fuel in the vault by annular flow along the channels between the storage tubes, induced by the buoyancy head of the heated air. 


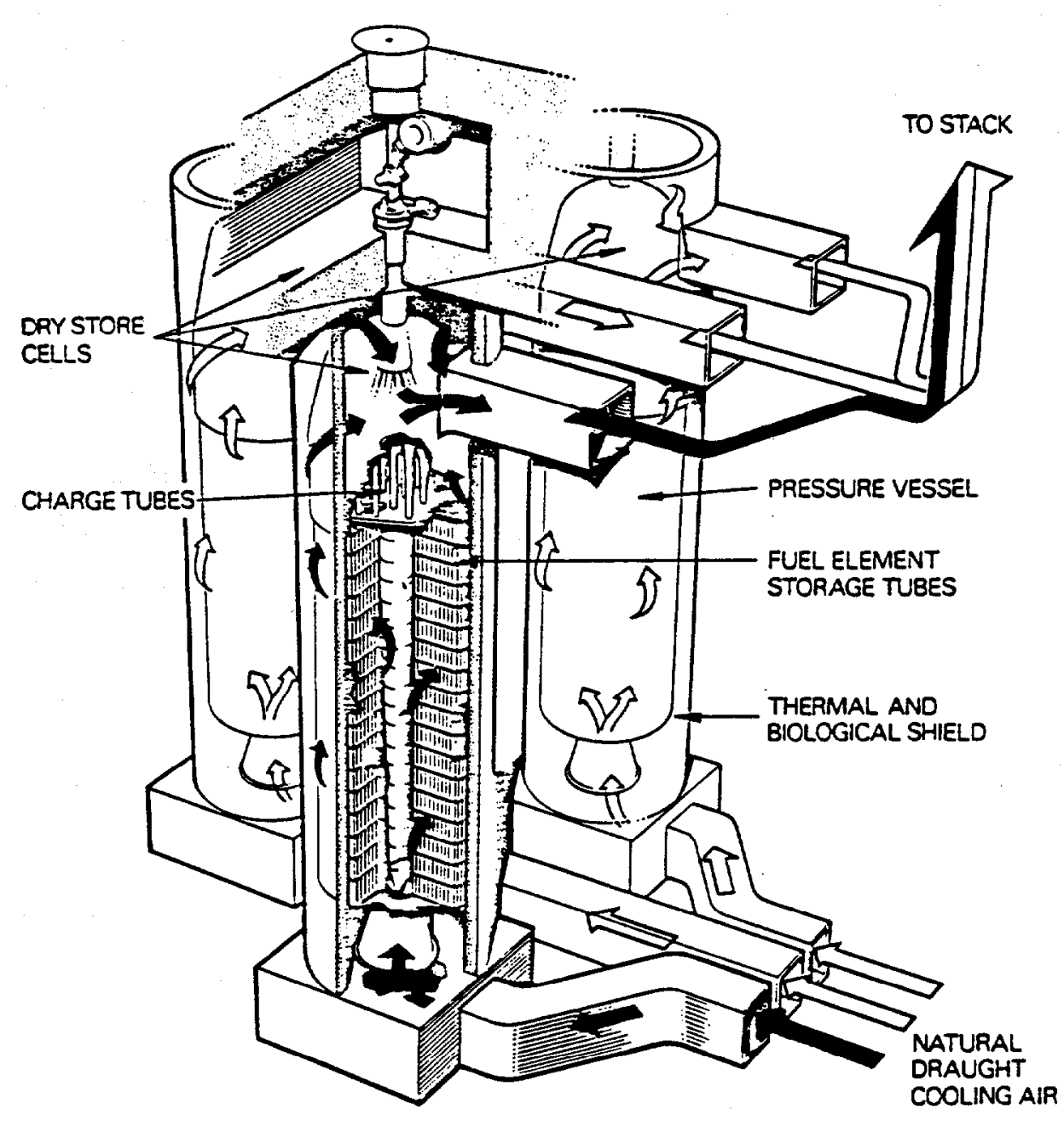

Fig. 2.25. Wylfa dry storage system (courtesy of GEC).

6. Corrosion control within the vault by preheating the incoming, cool, ambient air with part of the warm outlet air by means of a venturi educator in the inlet air ducts.

7. Provisions for cask buffer storage, radwaste treatment, equipment maintenance, and associated services.

\subsubsection{Small dry vault facility}

Figure 2.27 illustrates a GEC Energy Systems conceptual design of a small (200 tU) PWR or BWR dry storage vault. The building size is about $17 \mathrm{~m}$ by $20 \mathrm{~m}$ and contains a natural draft-cooled vault of air-filled storage tubes, a transport cask unloading and loading cell, and a fuel charging machine and gantry 


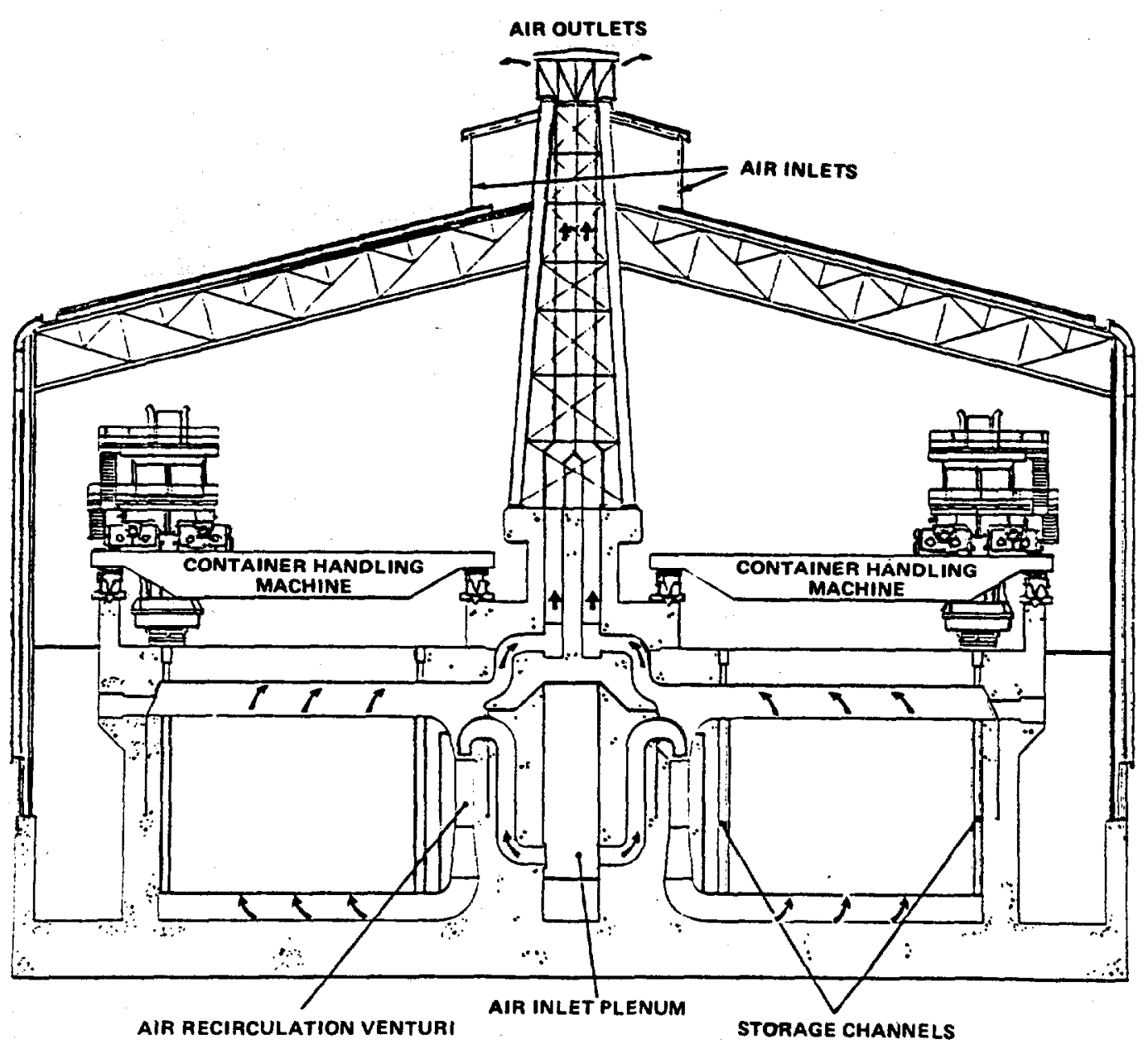

Fig. 2.26. AGR dry vault storage facility (courtesy of GEC).

\subsubsection{Status in the United States}

The GEC Energy Systems provided a preliminary vault design to TVA several years ago and submitted a topical report for a 166-PWR-assembly module to the USNRC in September 1986. GEC is represented in the United States by Foster Wheeler Energy Applications, Inc., of Livingston, New Jersey.

\subsubsection{French Vault Storage Designs ${ }^{3,7-10,18}$}

While the French have not designed or built dry storage vaults for spent LWR fuel storage, they have designed and built dry storage vaults for high-level solidified wastes, FBR spent fuel, naval and test reactor fuel, and plutonium. Since all of these have a similarity to storage facilities for LWR fuel, they are described in the following sections.

\subsubsection{Vault for dry storage of solidified high-level waste}

The French designed, constructed, and operated a dry storage facility at the Marcoule site in the late 1970 s. This facility received canistered high-level waste in the form of borosilicate 


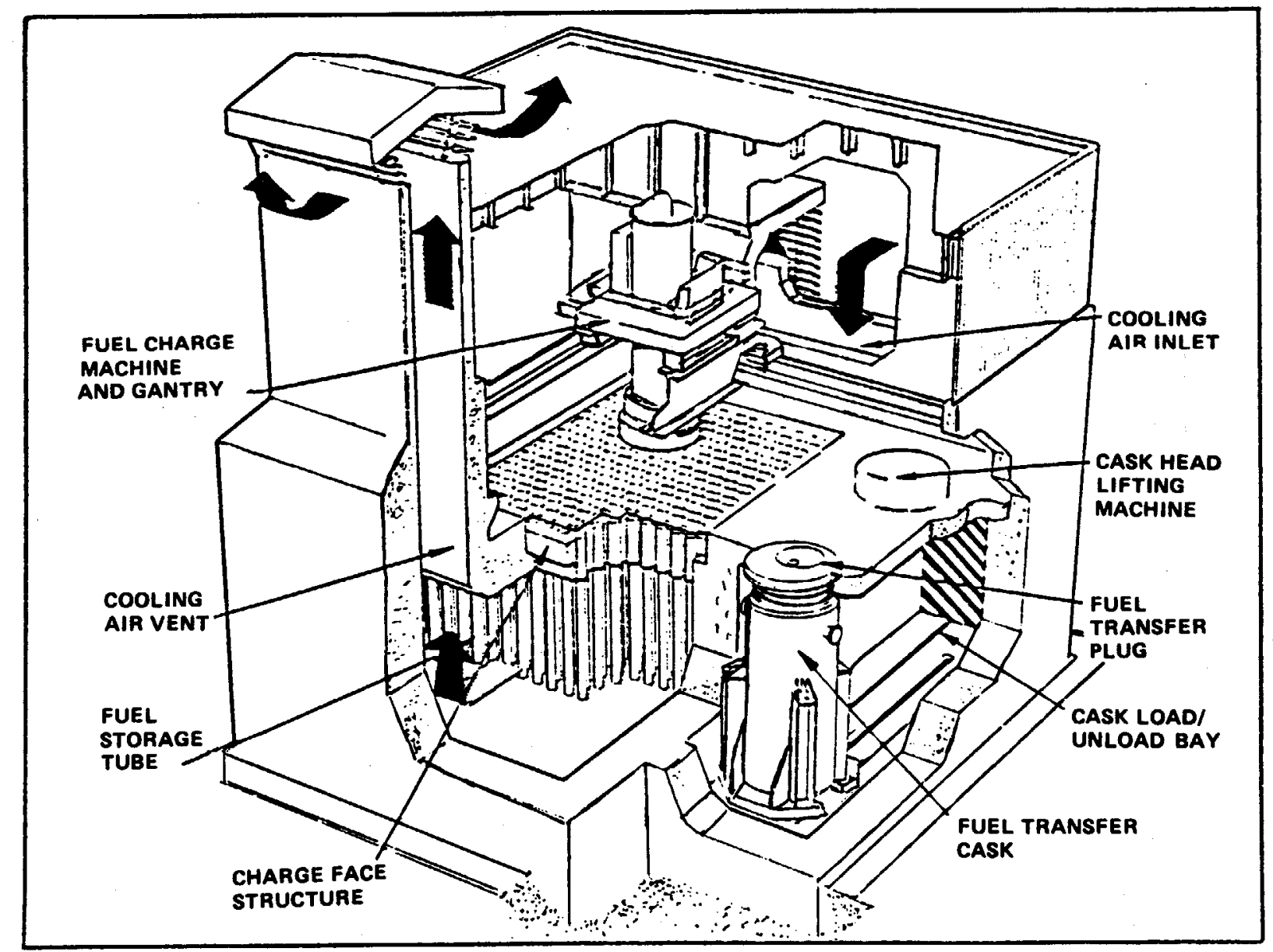

Fig. 2.27. GEC conceptual small dry vault storage facility (courtesy of GEC). 
glass produced in PIVER, a semi-industrial pilot plant for the demonstration of high-level waste vitrification. Some $12 \mathrm{t}$ of glass were produced during the period 1968-1973 and remain in storage in this facility. A similar but larger facility, the Atlier de Vitrification de Marcoule (AVM) plant, started operation in 1977. The storage wells in this facility are about $0.6 \mathrm{~m}$ in diameter and $9 \mathrm{~m}$ long. They are suspended from the upper floor slab and are free-hanging at the bottom. The upper slab carries the well closure plugs and also serves as the operating floor. Cooling is provided by air circulation between the wall and the canister, from bottom to top and around the outside of the wells.

Even larger facilities are under construction for use with the Atlier de Vitrification de La Hague (AVH) plants being built at the COGEMA-La Hague plant to service the fuel reprocessing units under construction there. These facilities are modular, consisting of ten units of 900 canisters each. Each module is independently regulated and capable of dissipating $31.5 \mathrm{~kW}$ per well. The wells are $10 \mathrm{~m}$ decp and can accommodate nine canisters each. The units are designed for forced circulation cooling during the early years of storage and for natural draft cooling over a longer period of time. The first of the two La Hague storage units is scheduled to start operation in 1987. SGN is licensed by the French CEA to provide design and engineering services for spent fuel/HLW storage based on this experience.

Figure 2.28 shows a picture of the operating floor at the AVM solidified HLW storage facilities in Marcoule. The circular plates on the floor of the facility are the tops of the plugs in the individual storage wells. Also shown positioned on the floor is the shicld valve, and above it is the transfer cask containing a canister of solidified HLW. In the left background is the plug cask. Figure 2.29 shows a diagram of the cooling circuits used in this facility.

\subsubsection{Vault for dry storage of FBR spent fuel}

A dry spent fuel storage system is used at the Traitement Oxyde Rapide (TOR) facility at the Marcoule site. This is a reprocessing plant for fast breeder reactor spent fuel and is capable of handling fuel from the Phenix, KK-2 (West German), and Super-Phenix reactors. Designed by SGN, construction began in 1980, and the TOR was placed in service by the CEA in 1985. One section of this plant includes a consolidated spent fuel receiving and storage facility consisting of (1) a dry unloading line for the transportation casks (each cask contains nine consolidated fuel rod canisters), (2) a monitored retrievable storage facility with 77 wclls, each well holding from three to five storage canisters, and (3) a canister handling system. The equipment in the facility includes a remotely operated bridge crane equipped either with a hoisting unit or an electromechanical telemanipulator, a closed circuit camera, and telemanipulator tools.

Operation of the facility is by remote control. The incoming spent fucl cask is set up on a self-propelled dolly which transfers the cask from the receiving hall to the unloading bay with the shielded gate closed. Venting of the cask is accomplished when the cask is connected to the unloading cell off-gas line, and the gate valve of the shielded cask bay is opened. The cask plug is placed inside the unloading cell using the electric gripper of the hoisting unit, and finally the consolidated fuel rod canisters are unloaded from the cask.

Operators in the central control room monitor the unloading operations and select the storage wells to be filled. The cell crane removes the well plugs, transfers the storage canister into the wells, and then puts the plugs back in place. The wells are made of two tubes inserted in a concrete structure, the upper part of which forms the floor of the dry unloading cell. Ventilation of the wells is independent of the unloading cell ventilation. Under standard operating conditions, 


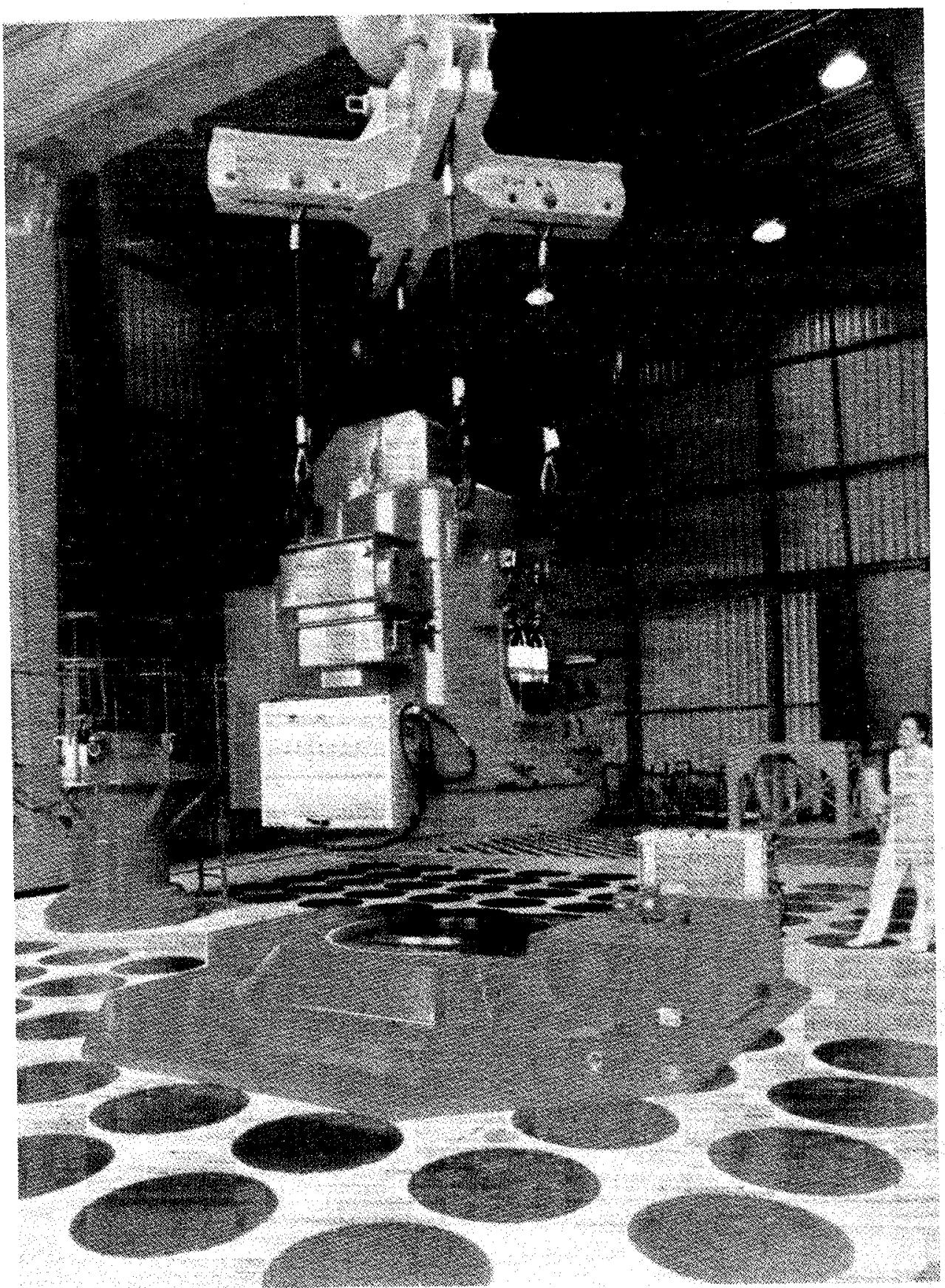

Fig. 2.28. Dry HLW storage facility at COGEMA - Marcoule plant (courtesy of SGN). 


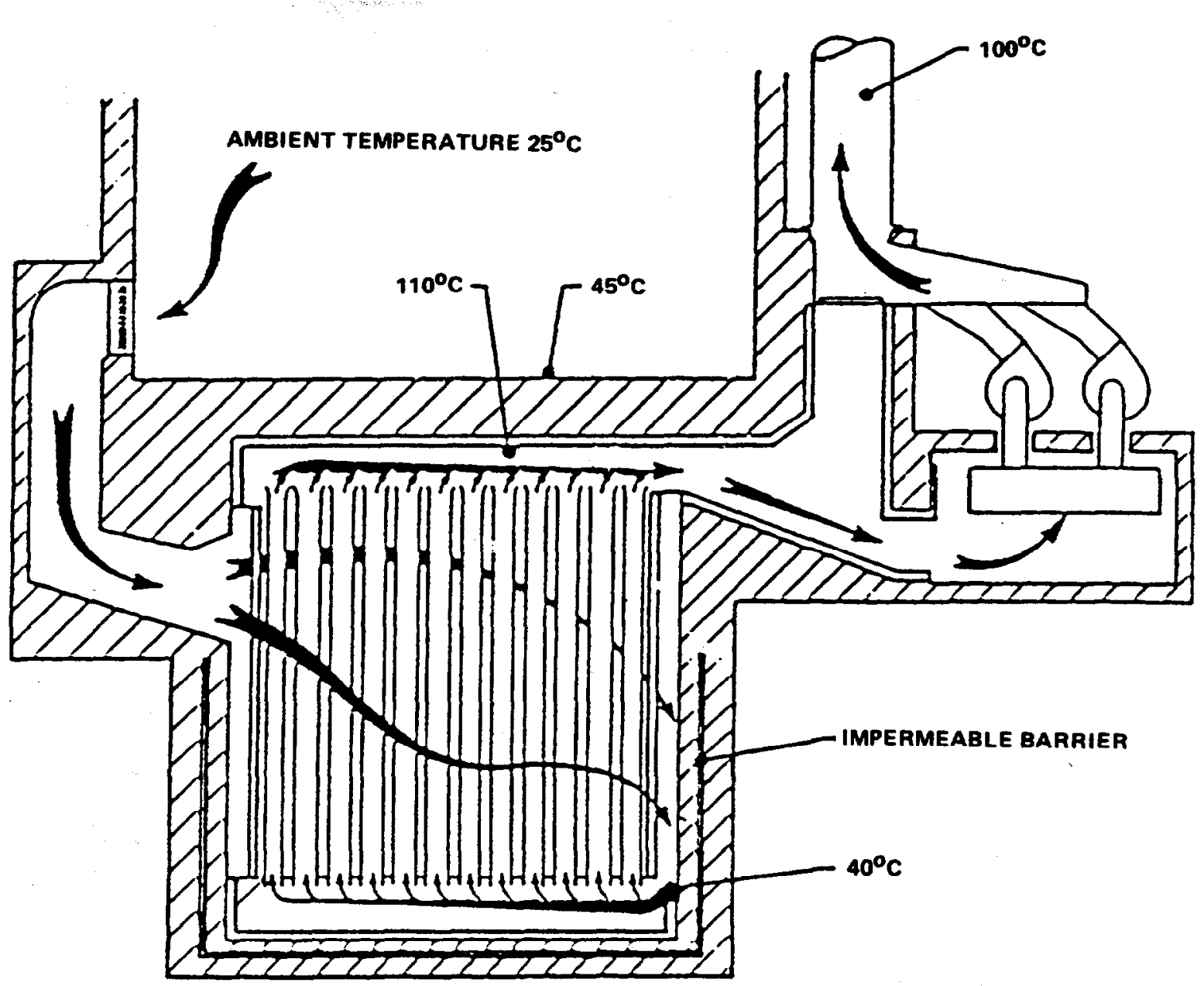

Fig. 2.29. Diagram of cooling circuits used in dry storage of HLW (courtesy of SGN).

the air outlet temperature is $50^{\circ} \mathrm{C}$, and the heat release rate is $4.3 \mathrm{~kW}$ per well. Each well is equipped with a shock absorber which can be changed remotely. Figure 2.30 is a view of the operating floor of the storage facility with three of the shield plugs removed to reveal the storage wells.

From the foregoing, it is apparent that this spent fuel storage facility is generally similar to the radioactive glass storage units previously described. Table 2.4 compares the principal characteristics of the TOR, AVM, and AVH storage units.

\subsubsection{Vault for dry storage of naval and test reactor spent fuel}

Another dry storage system under design by SGN is for a facility at the CEA-Cadarache site to store special types of spent fuel such as those from naval and test reactors. It is intended to be a monitored retrievable storage facility for long-term storage under closely controlled conditions. The principal features and capabilities of the facility include:

1. dry cask unloading;

2. dry storage in ventilated wells, cooled by natural convection without any filtration of the cooling air; 


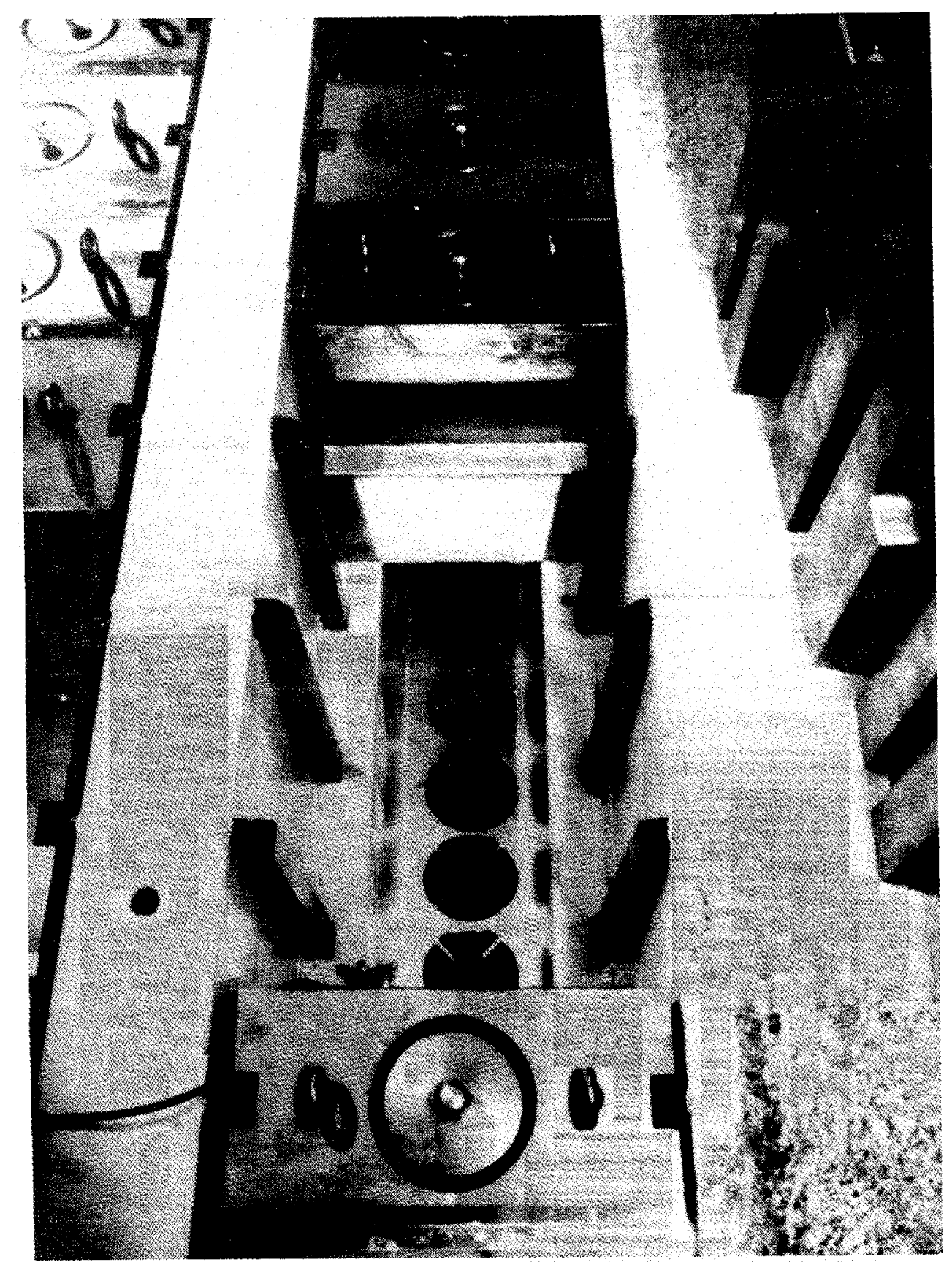

Fig. 2.30. Dry spent fuel storage facility at the TOR FBR reprocessing plant at Marcoule (courtesy of SGN). 
Table 2.4. Characteristics of TOR, AVM, and AVH dry storage facilities

\begin{tabular}{llll}
\hline \multicolumn{1}{c}{ Characteristic } & \multicolumn{1}{c}{ TOR } & \multicolumn{1}{c}{ AVM } & AVH \\
\hline Products stored & $\begin{array}{l}\text { Phenix and } \\
\text { Superphenix FBR } \\
\text { fuel pin canister }\end{array}$ & HLW glass canister & $\begin{array}{l}\text { HLW glass } \\
\text { canister }\end{array}$ \\
Number of storage wells & 77 & 220 & 500 \\
Heat rate per well $(\mathrm{kW})$ & 4 & 13 & 31.5 \\
Canisters per well & 3 to 5 & 10 & 9 \\
Well height (m) & 10 & 10 & 11 \\
Maximum external temperature $\left({ }^{\circ} \mathrm{C}\right)$ & & & $210-240$ \\
$\quad$ Normal operating conditions & 90 & 450 & 260 \\
$\quad$ Upset operating conditions & 130 & 450 & $90-105$ \\
Maximum concrete temperature $\left({ }^{\circ} \mathrm{C}\right)$ & & & $90-105$ \\
Normal operating conditions & 50 & $45-110$ & 110 \\
$\quad$ Upset operating conditions & 80 & $60-165$ & 140 \\
Air outlet temperature $\left({ }^{\circ} \mathrm{C}\right)$ & & & 100 \\
$\quad$ Normal operating conditions & 50 & 150 & \\
Upset operating conditions & 60 & &
\end{tabular}


3. modular storage for spent fuel assemblies having a burn-up of 15,000 to 20,000 $\mathrm{MW}(\mathrm{d}) / \mathrm{tU}$;

4. two containment barriers: spent fuel assemblies are in sealed canisters which are inserted into wells sealed by metal plugs;

5. retrievability of the stored fuel for reprocessing or final disposal during and after the storage lifetime of 50 years; and

6. design flexibility permitting the facility to meet changing requirements of handling rate and storage capacity. follows:

The general sequence of operations performed in this conceptual storage facility is as

1. receipt of casks with the associated handling and control operations;

2. testing of cask seals;

3. measurement of the internal cask atmosphere to detect damaged fuels;

4. hookup of connecting devices to the cask;

5. connection of the cask to the unloading cell receiving port;

6. removal of the ccll plug and cask plug;

7. introduction of the storage canister into the unloading cell and removal of the lid;

8. emplacement of the spent fuel assemblies in the canister and repositioning of the lid;

9. testing for canister tightness and filling with inert gas;

10. transfer of the canister into the storage well and emplacement of the cell plug; and

11. monitoring the activity of the storage area.

\subsection{DISASSEMBLY AND CONSOLIDATION EQUIPMENT', ${ }^{3,7}$}

\subsubsection{DEC System}

The SGN has recently developed a spent fuel disassembly and consolidation system (called DEC) for the COGEMA-La Hague plant. It has a nominal throughput capacity of $1600 \mathrm{tU} /$ year, based on $365 \mathrm{~d} /$ year operation and a $50 \%$ plant factor. Thus, 3276 spent fuel assemblies $50 \%$ PWR \{[900 MW(e)] and 50\% PWR [1300 MW(e)]\} having cooled for at least 3 years will be consolidated in 182 days of operation by a single disassembly machine. The basic capabilities of the DEC facility include (1) receipt of spent fuel, (2) dry disassemby of spent fuel, (3) consolidation of fuel rods into a canister, (4) volume reduction of structural parts, (5) emplacement of compacted structural parts in a canister, (6) monitoring the integrity of the fuel rod canisters for leakage or prospective leakage of radioactive materials, (7) storage of the canisters of fuel rods and compacted structural parts, and (8) removal and transfer of the storage canisters to the reprocessing plant.

*The detailed design of the DEC system has been completed, but its construction has been deferred until a clear need can be established. 
This consolidated facility permits the disassembly of spent fuel assemblies and subsequent consolidation of the rods into densely packed arrays. The fuel is disassembled by cutting off the upper end fitting and then removing all the fuel rods at one time by means of a multiple-rod pulling tool. Fuel rods are then placed in an interim storage transfer canister where sensors count the rods and check that none has been damaged. The fuel rods in the interim transfer canister are then transferred into a storage canister. The close-packed rod array results in a consolidation ratio of 2:1. Lockable covers are installed on the filled canisters before they are removed for storage.

The DEC facility has one disassembly cell equipped with a remotely operated and maintained disassembly machine. This machine is capable of cutting the PWR guide tubes to remove the top end fitting, grappling and pulling all the fuel rods simultaneously, and placing these rods into a canister. The fuel skeleton is sheared and compacted for volume reduction. The disassembly machine is flexible enough to handle all PWR fuel designs by changing the rod-pulling tool.

All machinery is automated and designed in modules so that it can be easily maintained and remotely operated and replaced. The consolidation system is controlled from a panel at the work station. A TV system is provided for remote viewing of all consolidation operations, although direct viewing by means of shielded windows is also possible. Operating sequences for disassembly are as follows:

1. installation of the fuel assembly on a tilting table;

2. lowering the tilting table to the position where the fuel assembly upper end fitting is in front of the drill head;

3. drilling of the central guide tube of the fuel assembly;

4. orienting the fuel assembly to the horizontal position on a transfer table in front of the guide tube cutter;

5. disassembly of the upper end fitting by cutting the 25 guide tubes;

6. raising the tilting table, gripping the upper end fitting with a holding jaw, and placing it in a waste canister;

7. positioning the transfer table in front of the multiple rod pulling tool;

8. pulling all the rods simultaneously;

9. positioning the transfer table in front of the tilting table;

10. lowering the tilting table to grapple the assembly skeleton and lift it into the vertical position;

11. introduction of the fuel assembly skeleton into the shearing machine with the hoisting unit;

12. alignment of the rods in the interim transfer canister;

13. counting the rods with sensors and verifying that no rod has been broken and that all of the rods of the fuel assembly have been removed;

14. actuation of the canister transfer piston;

15. transferring the fuel rods into the consolidated fuel storage canister;

16. installing the locking cover assembly on the upper position of the canister with a telemanipulator; 


\section{7. raising the tilting table; and}

18. handling the consolidated fuel canister with the cell crane.

Control consoles, located on the work platforms in the aisles of the hot cell, house (1) a programmable controller, (2) instrumentation and controls for the hoist assembly, (3) an $x-y$ positioning table, and (4) a transfer table, the drill head, and the multiple rod puller. The entire fuel consolidation process is designed to be controlled to minimize operator error.

The fuel assembly structural parts remaining after the fuel bearing rods have been removed must be reduced in volume before being packaged for disposal. SGN does not use a shredder for reducing the volume of structural components because remote operability, ease of decontamination, and repair has not been proven. Instead, a shearing machine has been adapted for the non-fuel-bearing materials reduction system from the numerous shears SGN has put into radioactive remote operation.

The non-fuel-bearing material is held with a gad during the shearing operations. A shearing force of about $30 \mathrm{t}$ is required, while the compaction force is $10 \mathrm{t}$. This equipment systematically shears sections of the grid and guide tube assembly. A PWR skeleton volume reduction operation requires about $15 \mathrm{~min}$ (this shearing machine has a 2-cuts/min capability). A 5:1 compaction ratio is easily achieved with this system, which has been in operation since 1967.

The compacted structural parts are placed in a canister, and the canister is monitored for decontamination, decontaminated if necessary, and shipped for disposal.

All the disassembly, consolidation, and volume reduction equipment and the cask unloading port and canister unloading bay are contained in a 1600-tU/year-throughput hot cell measuring $14 \mathrm{~m}$ by $7 \mathrm{~m}$ by $7 \mathrm{~m}$. Key equipment items are readily disassembled and maintained. The DEC facility was designed using state-of-the-art technology. The system is believed to be reliable, and is remotely maintainable. Disassembly equipment performance, criticality control, the potential for rod breakage, and personnel exposure have all been carefully analyzed in the initial phases of design development.

Figure 2.31 is an elevation view of the hot cell and Figs. 2.32, 2.33, and 2.34 are flowsheets for the disassembly, consolidation, and volume reduction operations. It should be noted that SGN, the designer of this equipment, was a partner of the U.S. General Electric Company in a first-round contract under the INEL spent fuel consolidation program.

\subsubsection{Canister Welding}

The canisters used to receive glass product from the AVM and AVH HLW vitrification plants are sealed by remote welding of the cover to the canister. The equipment used to perform this welding was developed by CEA through SGN. It was first put into service at the AVM facility in 1978 and has been in service there since that time. A second generation welder is scheduled to be installed at COGEMA-La Hague plant in 1987. This technology is directly applicable to the welding of canisters of spent fuel either for storage in a monitored retrievable storage (MRS) facility or for disposal in a repository.

Welding is effected by means of a plasma arc without filler metal. Weld continuity and strength are monitored by continuous recording of welding parameters (voltage, intensity, plasma generator gas flow rate, speed, shielding gas flow rate, and cooling water). Welding parameters and their allowable range of variation were established during a 12-month test period so that it is now possible to consistently produce high-integrity welds. The welding heads are capable of being remotely positioned, operated, removed, and maintained. The torch has a life of more than 


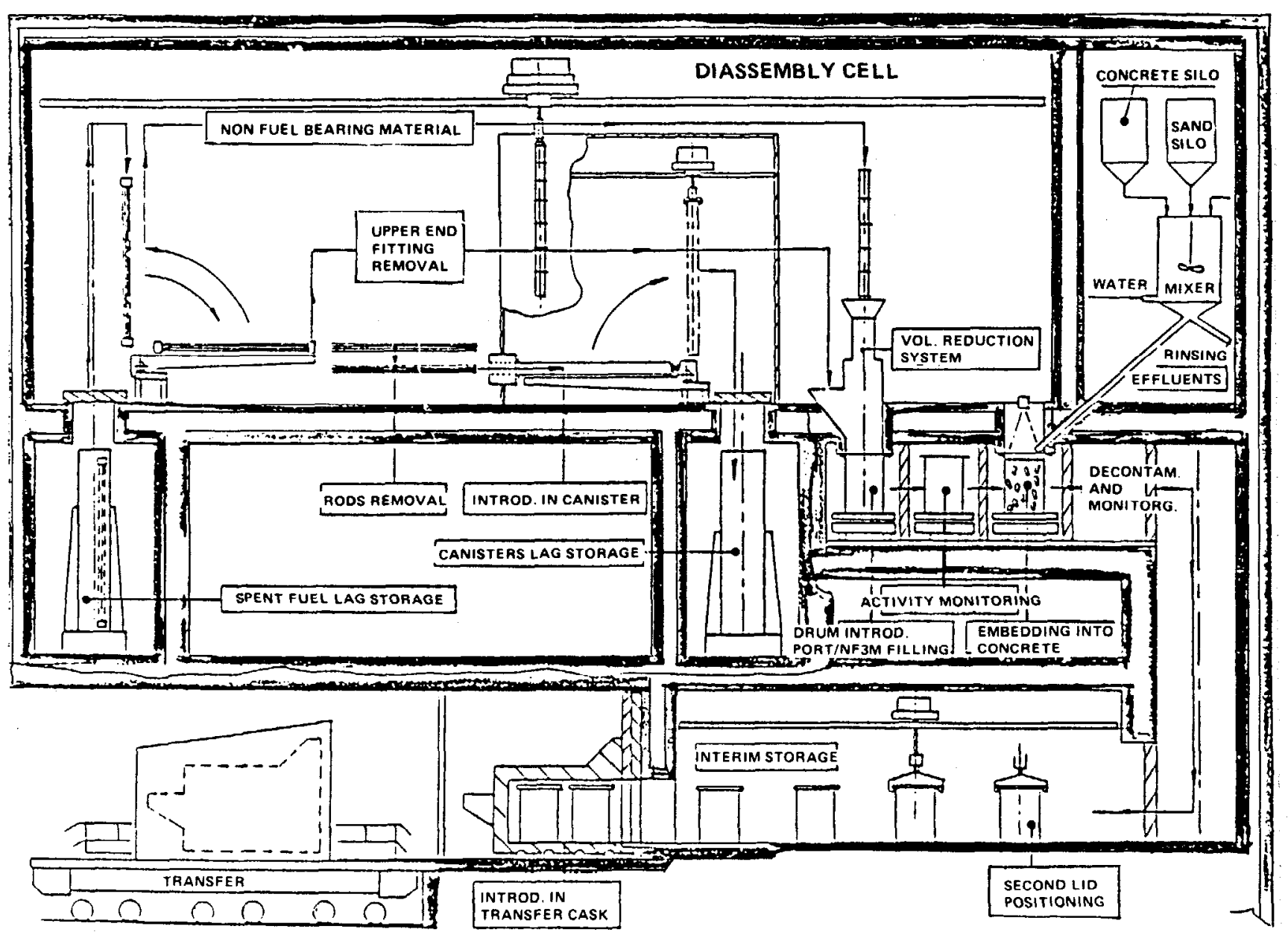

Fig. 2.31. DEC spent fuel disassembly and consolidation facility (courtesy of SGN). 


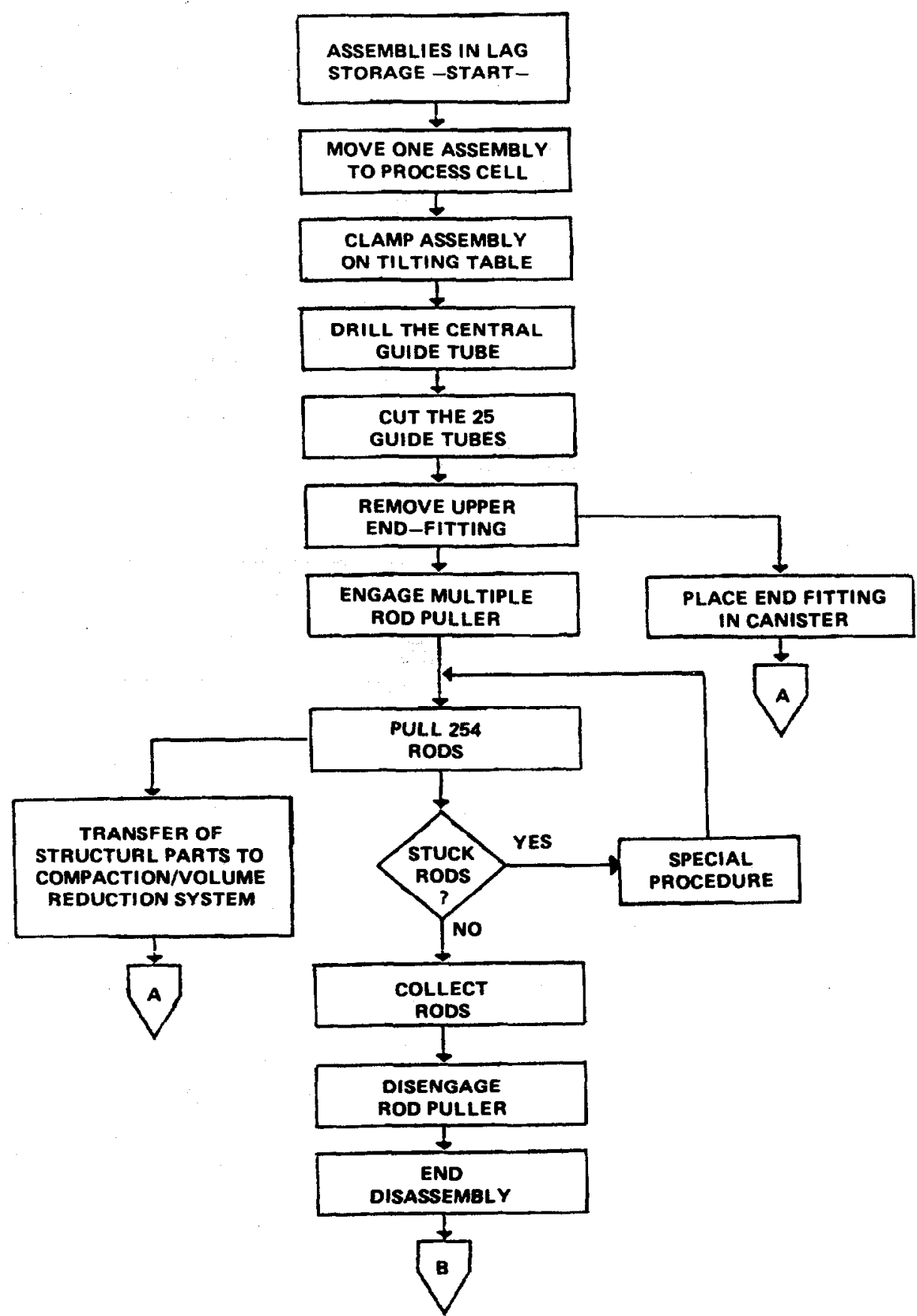

Fig. 2.32. Flowsheet for disasscmbly and consolidation operations (Part I) (courtesy of SGN). 


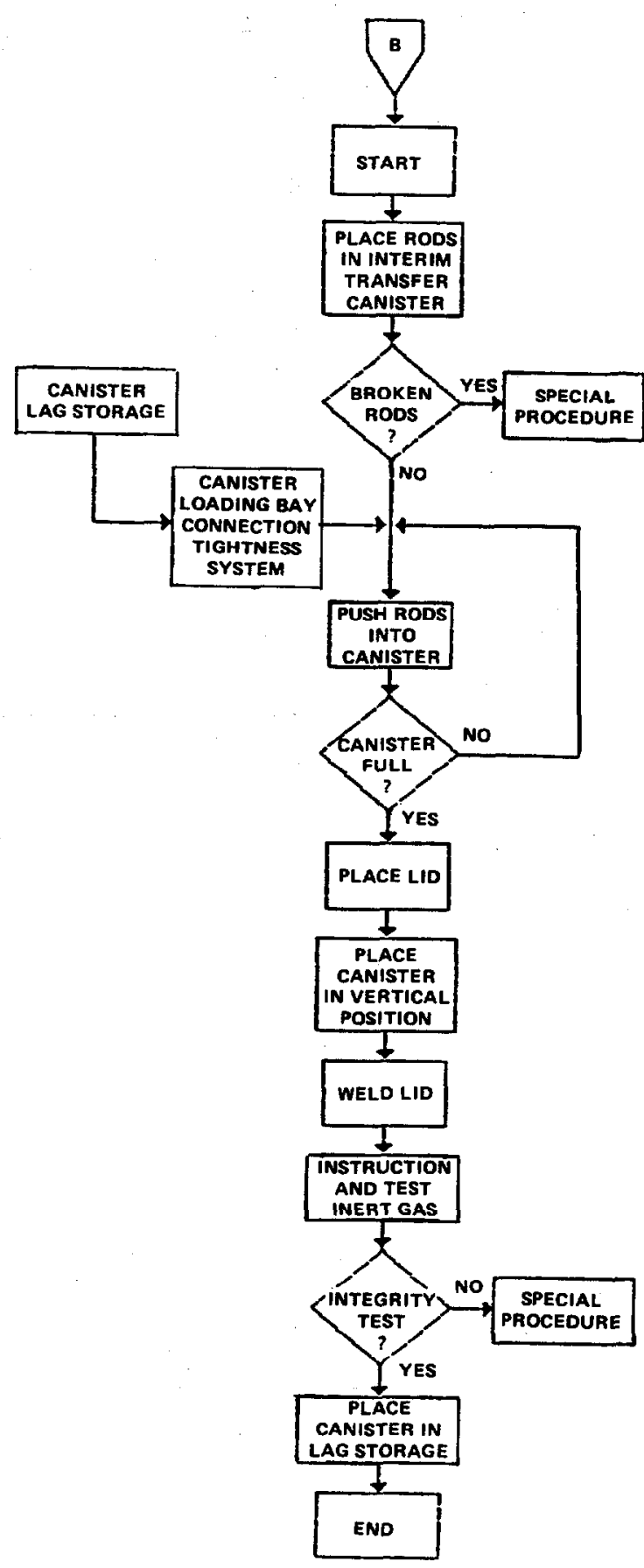

Fig. 2.33. Flowshect for disassembly and consolidation operations (Part II) (courtesy of SGN). 


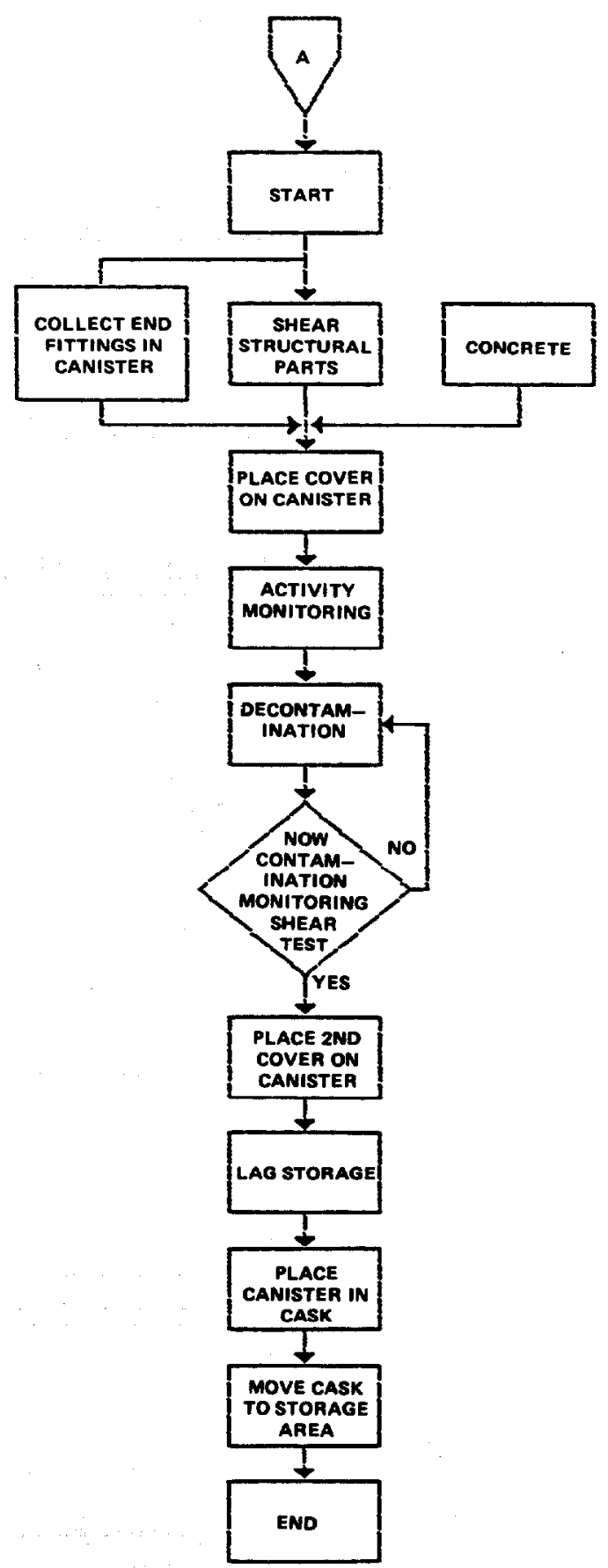

Fig. 2.34. Flowsheet for the volume reduction process (courtesy of SGN). 
100 welds without replacement of any parts. More than 1200 HLW canister lids have been welded in radioactive operations at the AVM.

The following are principal components of the welding machine:

1. a supporting framework;

2. a self-propelled dolly which receives the canister, places it under the welding head, and removes it after the welding operations have been completed;

3. a welding head bearing the welding torch (this head, with a rotary drive, is fitted with a mechanical seam follow-on system); and

4. a clamping system.

The entire machine is remotely maintainable and is of modular construction. Figure 2.35 is a sketch of the installation.

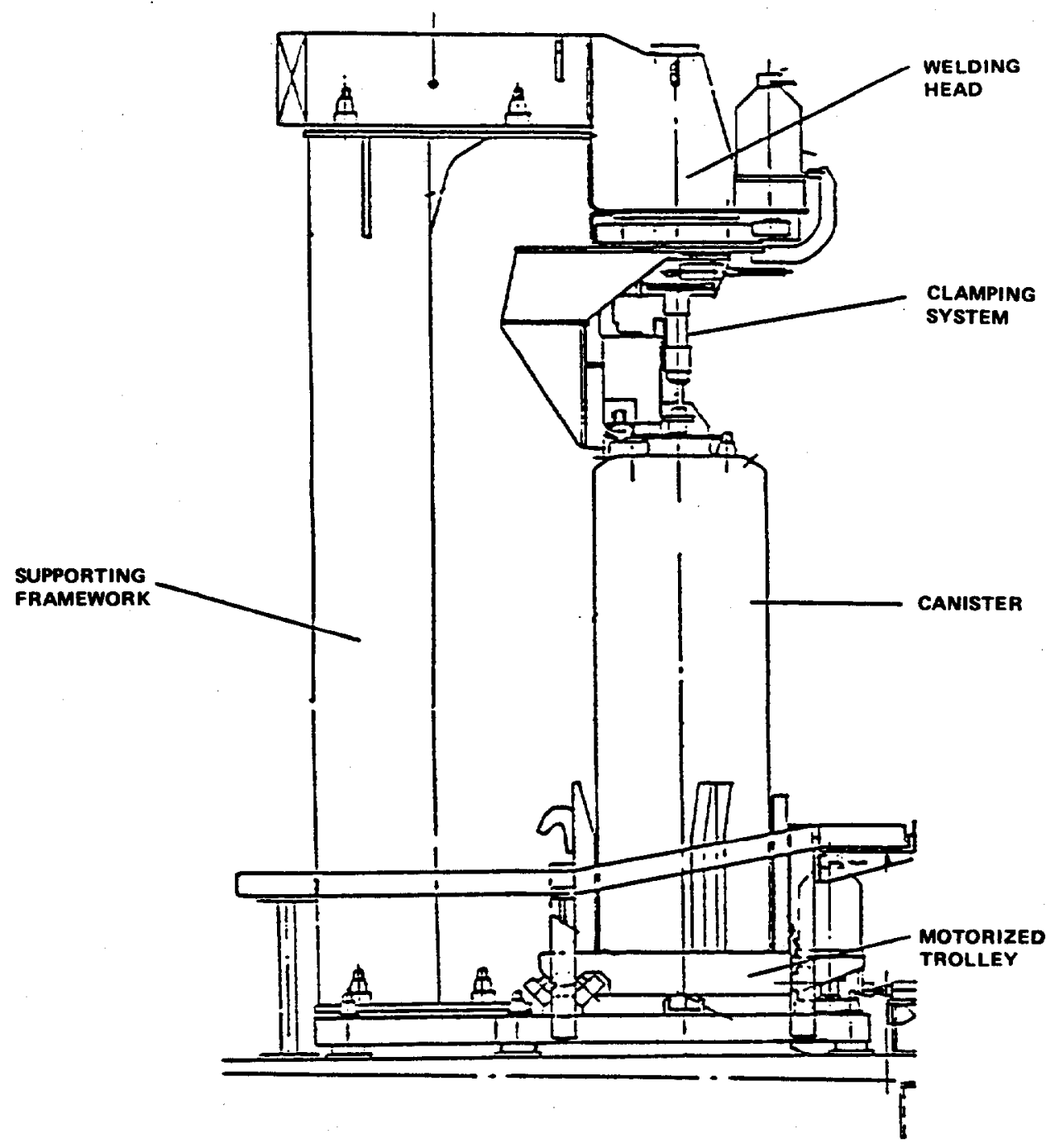

Fig. 2.35. Welding machine for canister lid (courtesy of SGN). 


\subsubsection{Canister Decontamination}

The SGN has developed a high-pressure water spray decontamination system for canisters of solidified HLW for use in the La Hague and Maroule vitrification facilities (Fig. 2.36). The decontamination system consists of (1) a feed tank for receiving either water or acid, (2) a high-pressure pump and accessories, (3) a decontamination bell fitted with intemal decontamination spray bars, (4) a condenser, and (5) an effluent receiving tank.

The decontamination bell assembly is mounted below the floor of the canning cell and is accessed through a loading port in the floor of the cell. The decontamination bell is first sealed to the loading port using an inflatable seal, and then the canister is lowered into the bell and the loading port is closed. The canister is rotated using a dual motor system while high-pressure spray is applied to the surface of the canister through nozzles distributed along a spray bar. Decontamination solutions are evacuated from the bottom of the bell through a penetration which is connected to a flexible hose. When the decontamination cycle has been completed, the bell is removed from the loading port, repositioned under an unloading port located in the floor of a monitoring cell, and sealed thereto. The unloading port is then opened, and the canister is removed for monitoring of its surface.

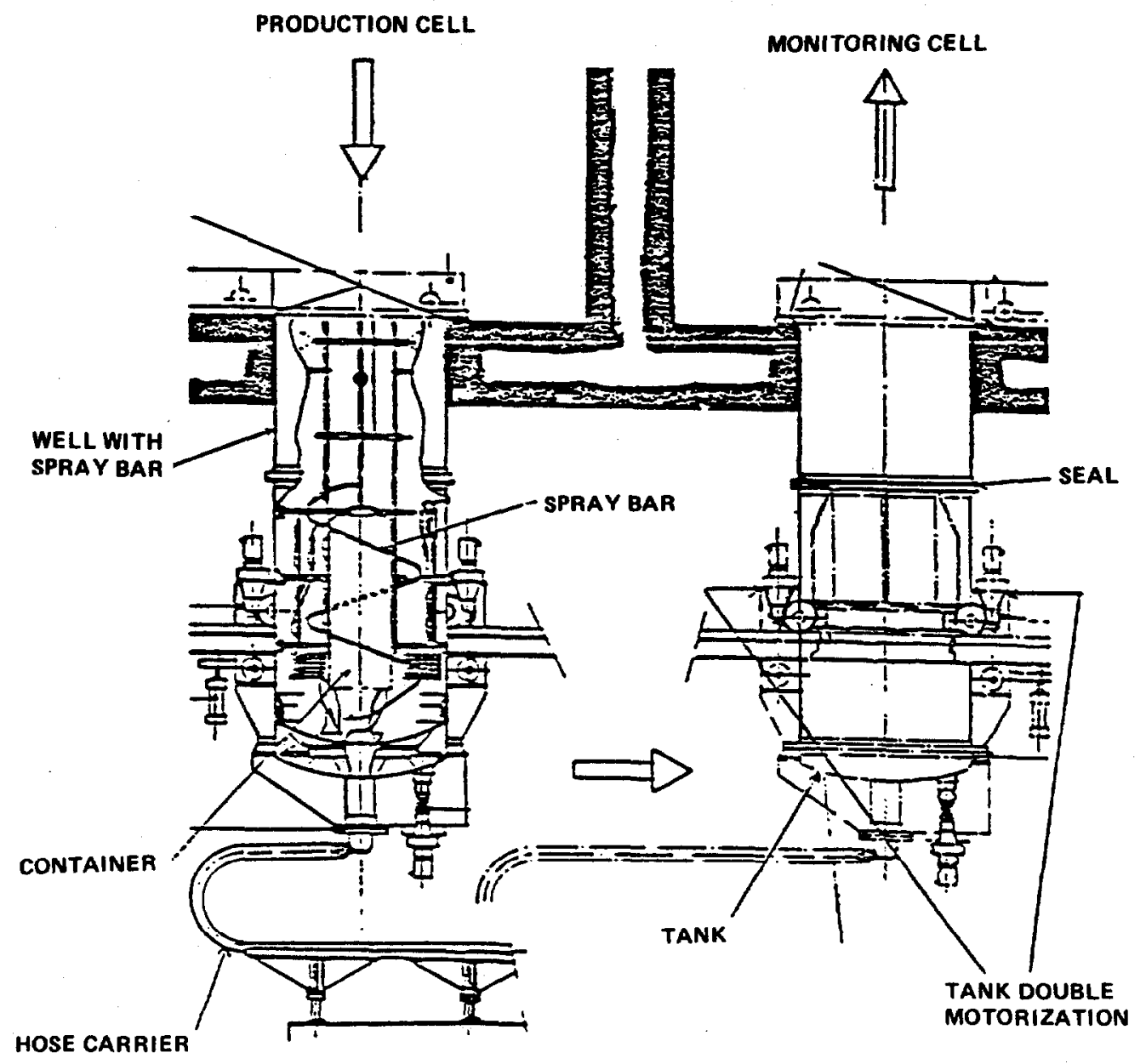

Fig. 2.36. High-pressure decontamination system for HLW canisters (courtesy of SGN). 


\subsubsection{Canister Monitoring}

Following decontamination, canisters are monitored by means of smear tests made over the entire canister surface. Measurement of the gamma activity level of the smears is performed in a counting unit installed outside of the ccll. The canister is placed in a motor-driven fixture which rotates the canister. A robotic arm containing a removable smear brush moves to contact the brush against the canister surface. The robotic arm moves slowly downward so that the brush contacts the entire surface of the canister. After the smear has been completed, the robotic arm rotates to the pneumatic transfer machine where the smear brush is removed. The smear brush is mechanically held in a support. After a smear has been completed, the support is inserted in the transfer system which provides the containment for the smear brush and pneumatically transfers it in and out of the cell. Smear test equipment is constructed of materials that are temperature resistant and have a texture that permits the reliable transfer of contamination from the canister to the brush.

This monitoring system (see Fig. 2.37 for a schematic diagram) consists of (1) a pneumatic transfer system for fresh smear brushes that are installed outside the cell, (2) an in-cell machine that receives the shuttle and installs the smear brushes on the monitoring machine, (3) a monitoring machine (see the following description), (4) a smear activity measuring unit installed outside the cell, and (5) a removal and reconditioning system for worn brushes. The contamination monitoring machine includes the following:

(1) A canister rotary drive system that permits smear tests to be made over a line progressing $360^{\circ}$ around the canister and traversing its full length. A spced indicating control is mounted between the driven roller and the idle roller. Rollers can be remotely disassembled for cleaning.

(2) A mechanically articulated system (robot) with five degrees of freedom (four motorized degrees). This system grips the smear brushes and allows the brush to contact the entire surface of the canister from the bottom to the lid.

Machine components are remotely dismountable and are of modular construction.

\subsection{SPECIAL HOT CELL EQUIPMENT ${ }^{3,7,10,19,20}$}

The French have developed a number of specialized equipment items for facilitating operations in hot cells and in reducing the time required for maintenance activities associated therewith. Many of these have been discussed earlier in this report. However, two additional items, a mobile equipment replacement cask (MERC) and a modular crane, may also find application in the FWMS and are described below.

\subsubsection{Mobile Equipment Replacement Cask (MERC)}

The CEA-SGN has developed the design of equipment for the remote removal and replacement of process equipment such as valves, pumps, filters, and other plant hardware requiring periodic maintenance. First, the specific piece of process equipment is designed in a modular form so that it can be disconnected readily from piping and electrical services. In addition, the equipment is mounted directly above (or below) a plugged access port in the hot cell so that it can be reached for remote removal and replacement by the MERC unit. When an equipment item needs to be replaced, the MERC unit is moved and sealed to the access port so that when the shielding plug is removed from the port, full containment is maintained. Moreover, 


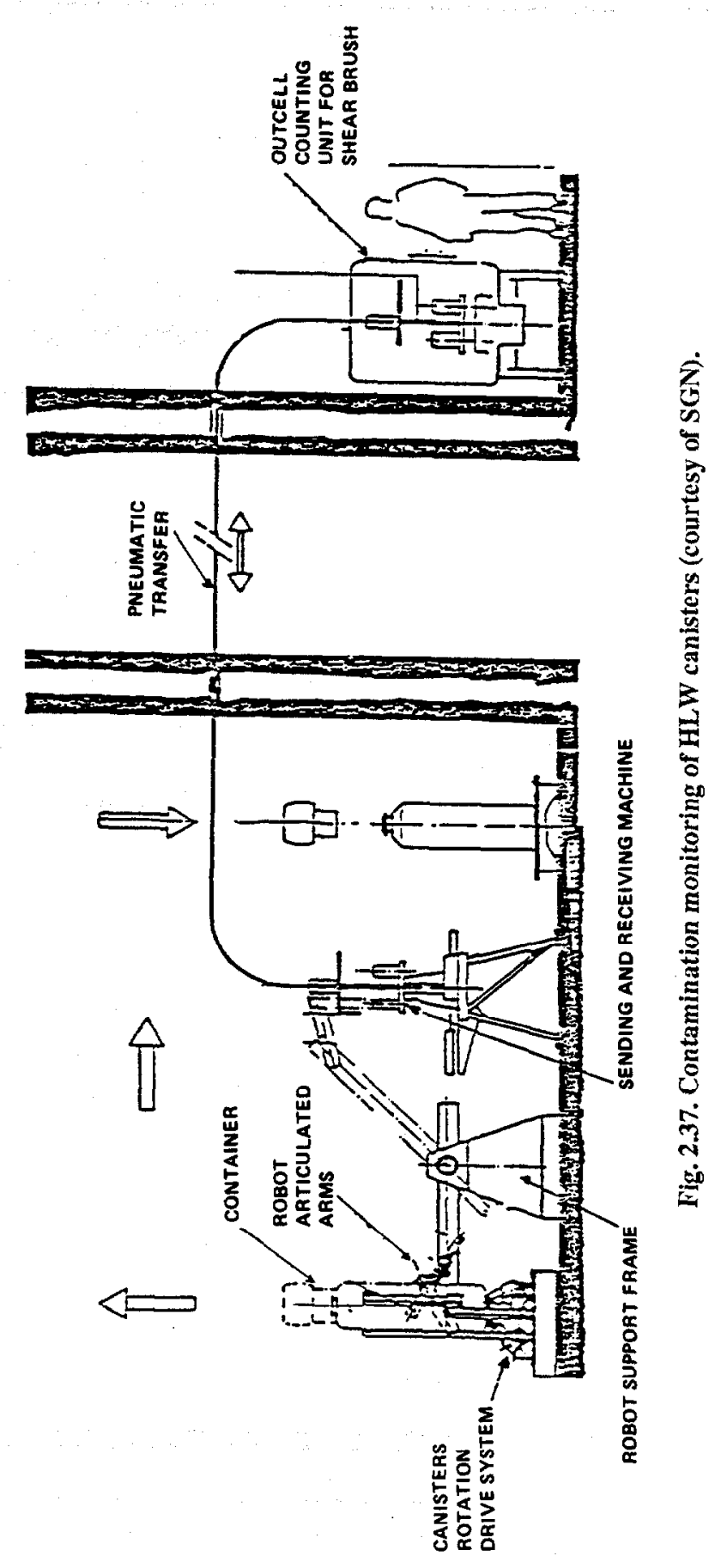


the MERC unit is itself fully shielded for radiation protection when the access port is open and when the unit contains a contaminated equipment item that has been removed. The overall system makes it possible to remove equipment rapidly from a hot cell for replacement or maintenance purposes, and to replace them with minimal impact on operations and with complete containment of contamination.

Two types of transfer casks have been developed:

(1) A MERC with a sliding hatch for large equipment (up to $2.1 \mathrm{ft}$ in diameter and $6.5 \mathrm{ft}$ high), including a hatch cover connected to the cell containing the item to be removed and the transfer cask whose door is connected to the hatch when it is to be opened. The doors between hatch and cask are opened inside the containment, and the equipment to be removed is lifted inside the MERC with an automatic gripping device. The doors are closed and the cask is disconnected and transferred to the maintenance cell. The cask is shielded to reduce radiation in the maintenance area. Replacement equipment is brought in by another MERC and installed using the same principle.

(2) The revolving MERC for smaller equipment is an air-tight cask with separate chambers that can contain new and failed equipment simultaneously. Failed equipment can thus be removed and replaced by new ones in one operation with a single MERC.

The MERC system is used to facilitate many of the hot cell maintenance requirements at the La Hague reprocessing plant. Figures 2.38 through 2.43 show the salient features of the design and illustrate the use of this equipment.

\subsubsection{Modular Cranes}

The SGN has developed designs of modular cranes to reduce the time required for in-cell maintenance. In these designs, the failure-prone mechanical or electromechanical elements are grouped in modules which can be remotely connected to or disconnected from process or electrical systems by simple vertical movements. Design objectives for modular remotely-operated bridge cranes for various applications have included the following:

1. elimination of direct manual operations on the bridge crane subassemblies during maintenance;

2. elimination of the need for operators to be present in the crane maintenance cell (no contact maintenance);

3. standardization of the modular subassemblies;

4. capability for use of MERC to remove (and replace) subassemblies in standardized "containment" canisters for transport and treatment;

5. improvement of bridge crane performance by limiting overall dimensions and increasing accuracy of positioning; and

6. improvement of bridge crane reliability by using highly redundant reliable parts.

The modular remotely operated bridge cranes have separate modules for hoisting, transfer, cable storage, electrical supply, movement controls, and closed circuit camera. Modules are 


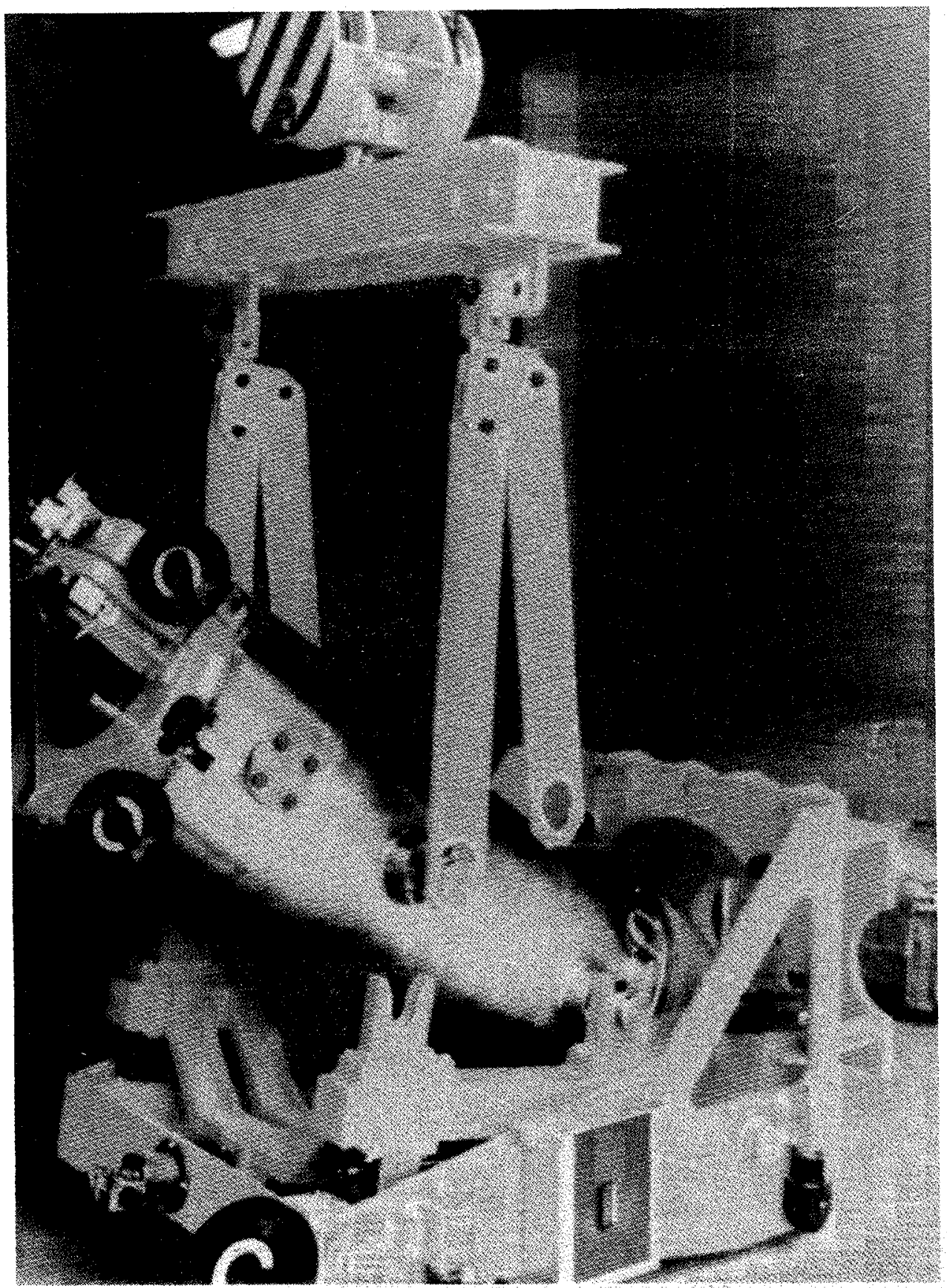

Fig. 2.38. MERC equipment being loaded on a horizontal axis cradle (courtesy of SGN). 


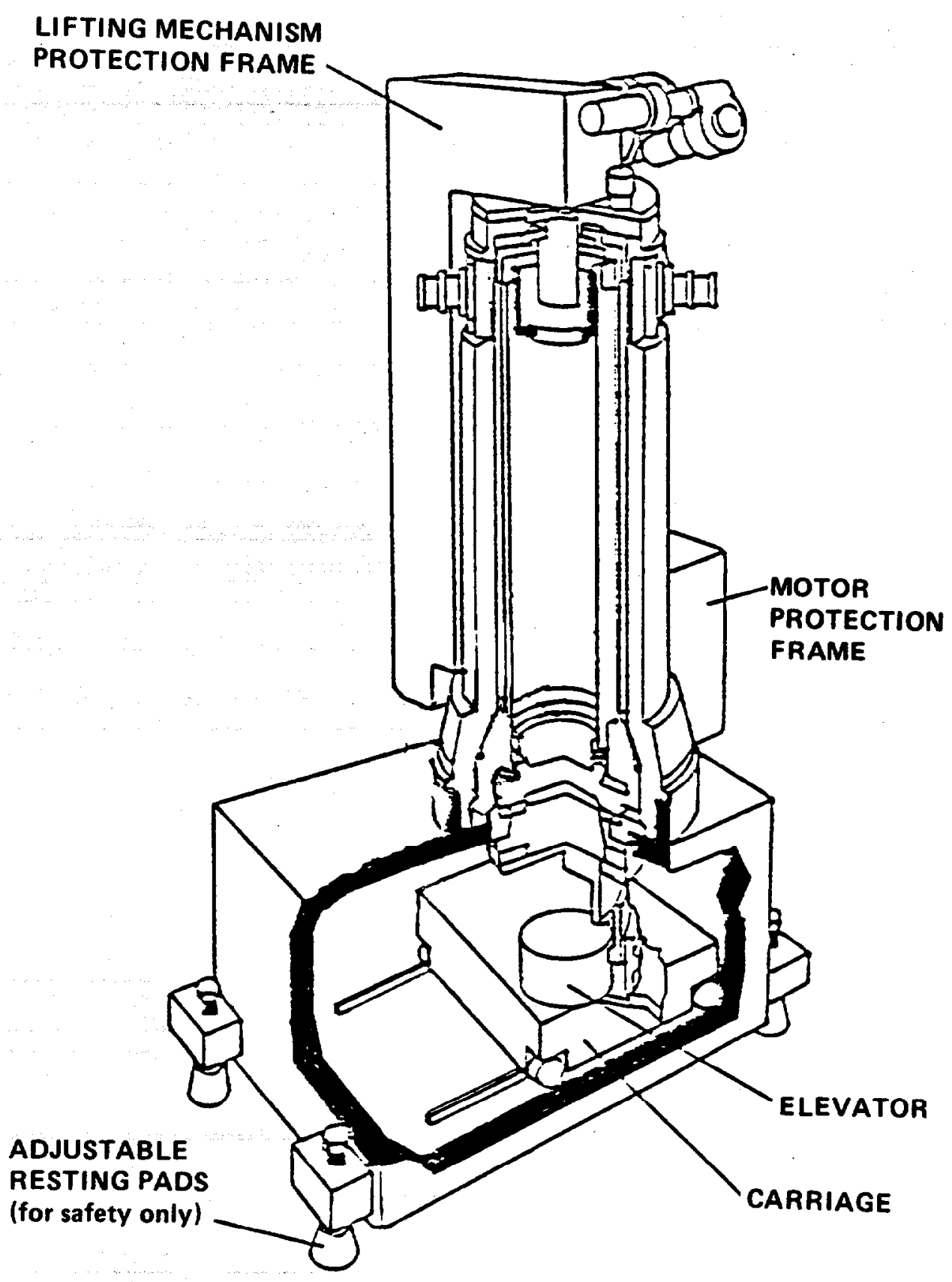

Fig. 2.39. Sliding hatch MERC (courtesy of SGN). 


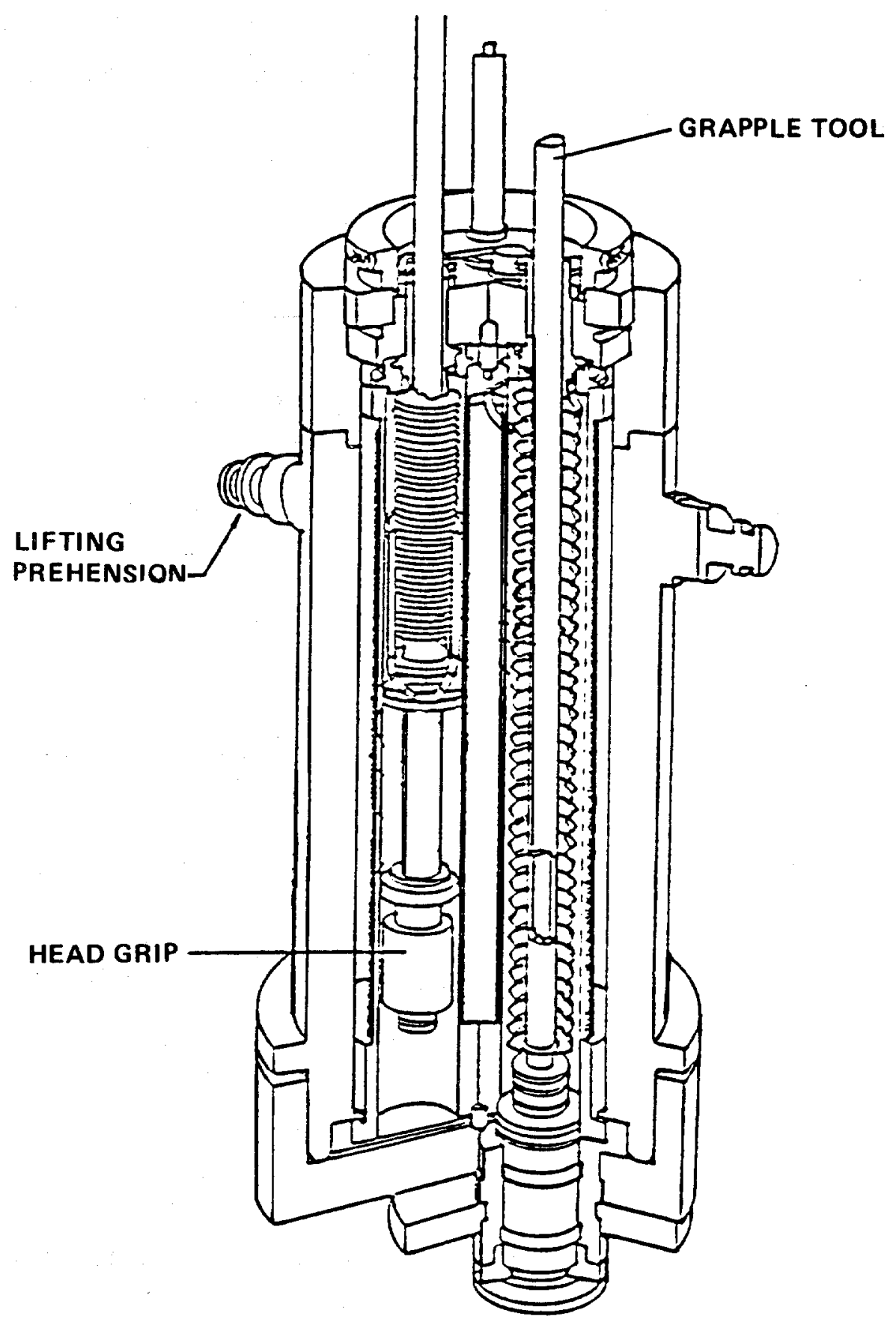

Fig. 2.40. Revolving MERC (courtesy of SGN). 

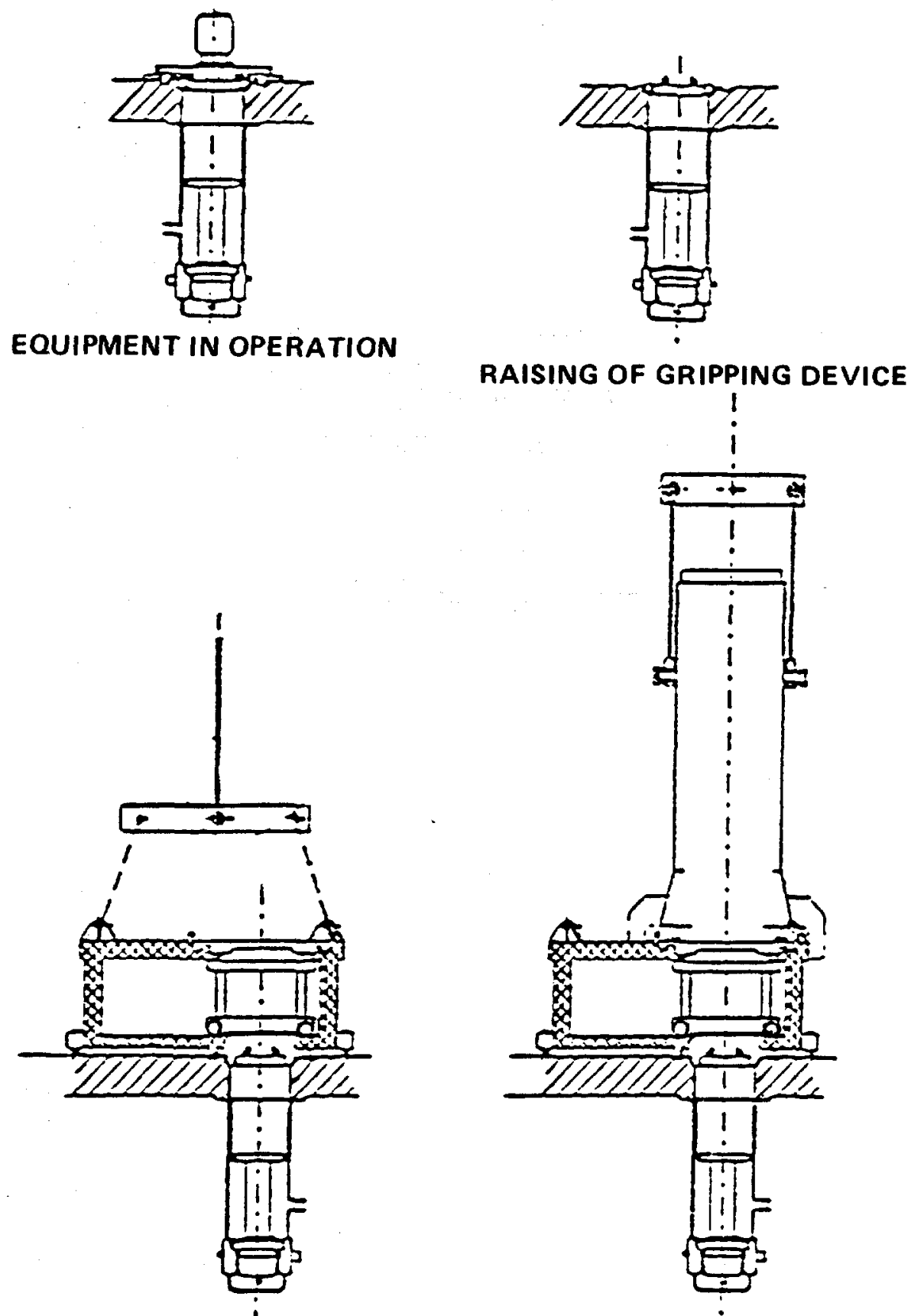

MATCH IN POSITION

ENCLOSURE POSITIONING

Fig. 2.41. Equipment removal preparation (courtesy of SGN). 

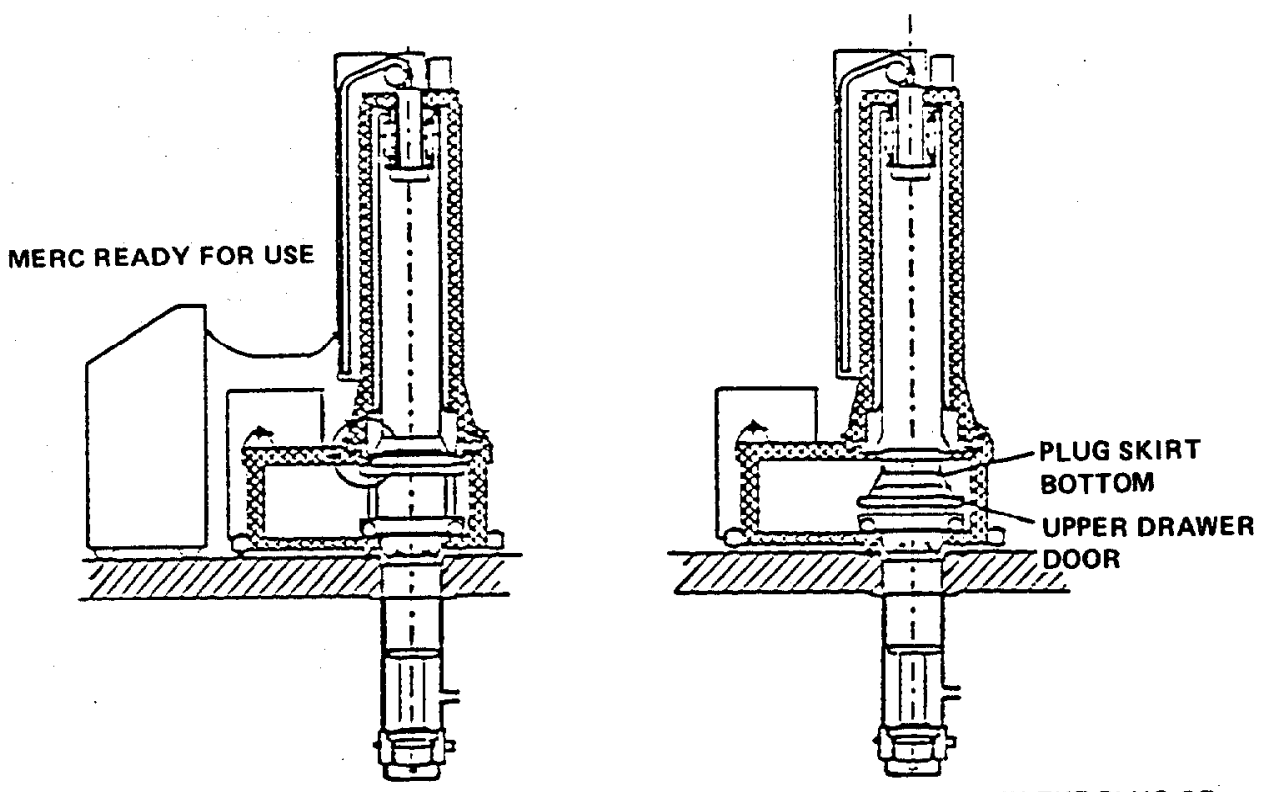

LOWERING ELEVATOR WITH THE PLUG OF SKIRT BOTTOM AND UPPER DRAWER DOOR
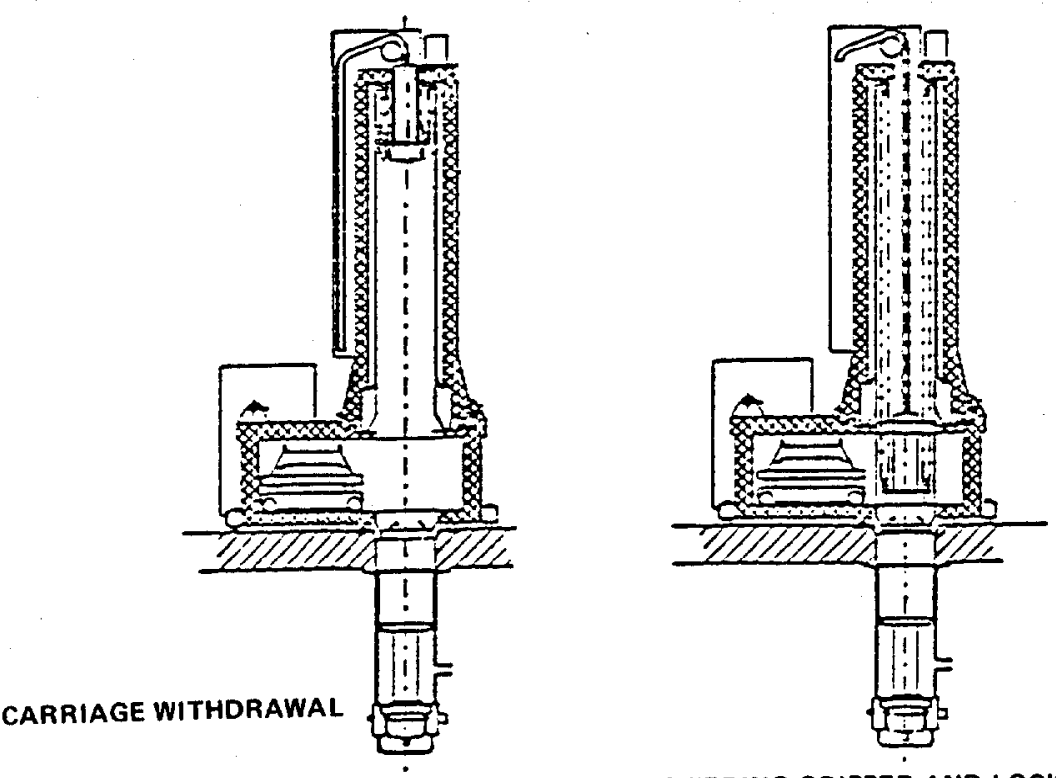

LOWERING GRIPPER AND LOCKING ON THE LOWER HATCH DOOR AND THE "WORN EQUIPMENT" GRIPPING ELEMENT

Fig. 2.42. Equipment removal by MERC (courtesy of SGN). 


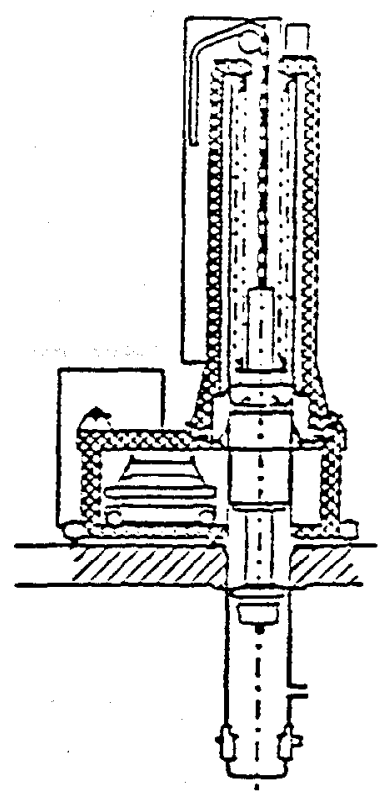

RAISING THE "WORN EQUIPMENT" WITH THE LOWER DOOR OF THE HATCH

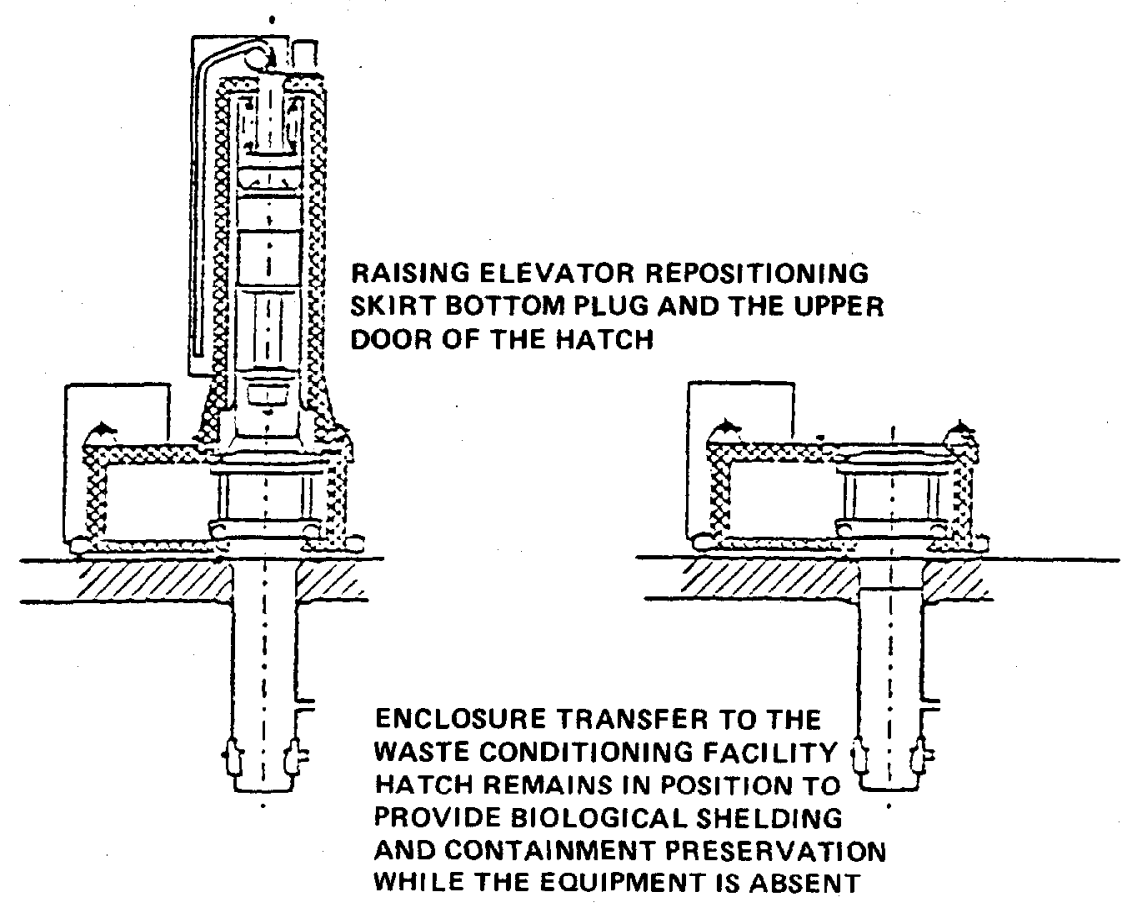

Fig. 2.43. Transfer of removed equipment (courtesy of SGN). 
connected to the bridge crane by automatic locks. Electrical connections are ensured with automatic locking connectors. The modular crane is installed in several facilities including the TO spent fuel receiving/unloading facility and the AVH vitrification facility.

\subsection{REPROCESSING EXPERIENCE $2,21-25$}

As discussed previously, the French and British nuclear power programs are committed to reprocessing their spent nuclear fuels. Both have over 30 years of experience in this regard, and most of the French and British technology described in this report has evolved from their respective activities.

Both France and the United Kingdom are exporting nuclear power technology internationally, and since they believe reprocessing is an essential element in an integrated fuel cycle, many of their foreign contracts provide for the return of spent fuel for reprocessing.

\subsubsection{French Reprocessing Experience}

The French began industrial-scale reprocessing at Marcoule (UP1 facility) in 1958 to separate plutonium for military purposes. In recent years this facility has become increasingly involved in reprocessing civilian power reactor fuel. The UP2 facility at La Hague was commissioned in 1966 to reprocess the spent metallic fuel from the early gas-cooled power reactors (GCRs) with a nominal design capacity of $800 \mathrm{tU} /$ year. During the period 1973 to 1976 , a new head-end facility (UP2-HAO) with a nominal capacity of $400 \mathrm{tU} /$ year was added to the La Hague plant to enable it to reprocess the uranium oxide fuels from the growing number of light-water reactors being built in France. In 1979 the oxide unit head end was further modified to accept and reprocess FBR (Phenix) fuels. In order to meet contractural commitments for the reprocessing of spent fuel, it was decided in 1977 to expand the UP2 plant to a nominal design capacity of 800 tU/year for LWR fuel (the new plant will be called UP2-800) and to build a separate reprocessing plant at La Hague called UP3, which is also scheduled to have a nominal design capacity of 800 tU/year for LWR fuel. The UP3 plant is scheduled to begin operation in 1989, and the UP2-800 plant is scheduled to start up in 1991.

The UP2-800 and UP3 plants are expected to involve a capital expenditurc of 40 billion French francs (1983 francs) and to require 30 million engineering hours in connection with their design and construction. The UP2-800 plant is being financed by Electricite de France and by COGEMA and will be used to process spent LWR fuel of principally French origin. The UP3 plant is being financed by contracts with 30 electric utility companies from six different countries and will involve the reprocessing of 7000 tU over the first 10 years of operation.

The spent fuel output of French GCRs has declined since 1978, so the UP1 plant in Marcoule has been converted to reprocess all of the GCR fuel at a capacity of $400 \mathrm{tU} / \mathrm{year}$. This has permitted the dedication of the UP2 plant to reprocess only oxide fuel. From 1976 through January 1987, the UP2 plant reprocessed 4,900 MTU of GCR fuel, and the last reprocessing run $(68 \mathrm{tU})$ was completed in January 1987. The reprocessing of FBR fuel has been moved to new production facilities at Marcoule.

A summary of the actual reprocessing experience at the UP2 plant is shown in Table 2.5. Care must be taken in using the data of Table 2.5 to calculate plant factor experience. The following describes some of the considerations involved. 
Table 2.5. La Hague (UP2) reprocessing history

\begin{tabular}{rrrr}
\hline & \multicolumn{3}{c}{ Design Capacity (tU/ycar) } \\
\cline { 2 - 4 } Year & GCR fuel ${ }^{2}$ & FBR fuel & LWR fuel $^{b}$ \\
\hline 1967 to 1975 & 2,365 & & \\
1976 & 218 & & 14.3 \\
1977 & 351 & & 17.4 \\
1978 & 372 & 2.2 & 36.8 \\
1979 & 264 & 1.6 & 75.3 \\
1980 & 268 & 1.9 & 102.0 \\
1981 & 275 & 0 & 110.0 \\
1982 & 226 & 2.0 & 154.0 \\
1983 & 117 & 2.1 & 221.0 \\
1984 & 185 & 0 & 255.0 \\
1985 & 109 & 0 & 351.0 \\
1986 & 76 & & 333.0 \\
1987 & 68 & 9.8 & $1,669.8$ \\
\hline
\end{tabular}

${ }^{a}$ The design capacity for GCR fuel is $800 \mathrm{MtU} /$ year.

${ }^{b}$ The design capacity for LWR fuel is $300 \mathrm{MtU} /$ year. One dissolver was removed from service in 1980 which was reported to have reduced the design capacity from 400 to $300 \mathrm{MtU} / \mathrm{year}$.

1. The activities of the UP2 plant during each year after completion of the shakedown and preliminary operation of the LWR head-end facilities were divided about equally between the reprocessing of GCR and LWR fuels. The FBR fuels were reprocessed during the GCR portion of the year.

2. The nominal capacities for spent LWR fuels mentioned earlier were based on the assumption that the plant would have a scheduled shutdown of 2 months each year for major maintenance, thus leaving a maximum of about 304 production days each year. Further, it was assumed that the actual available production time would be lower than this due to scheduled (cleanout and tooling changes between batches, and conversion of common elements of the reprocessing system from a GCR fuel reprocessing capability to a LWR fuel capability) and unscheduled shutdowns. Thus, an availability factor of 0.66 was estimated, leaving about 200 production days each year.

3. The plant design was based on the processing of four assemblies/d. The uranium content of the assemblies was assumed to be $500 \mathrm{kgU}$. A combination of this with the assumptions cited in (2) above produced an annual capacity of $400 \mathrm{MtU} /$ year, 
assuming that the entire year was devoted to the processing of LWR fuels. However, it should be pointed out that the design capacity of a reprocessing plant will vary widely depending upon the amount of uranium contained in the fuel assemblies being reprocessed. None of the LWR fuels processed to date have been as high as the $500 \mathrm{kgU} /$ assembly used to compute the foregoing annual capacity. Rather, the uranium content of the fuels reprocessed has varied from $120 \mathrm{kgU} /$ assembly to $460 \mathrm{kgU} /$ assembly, thus making the annual design capacity for the plant range from about $100 \mathrm{MtU} / \mathrm{year}$ for the lightest fuel assembly to about $370 \mathrm{MtU} / \mathrm{year}$ for the heaviest assembly processed. (Actually, it would be more appropriate to express the design capacity in terms of assemblies/year rather than $t U /$ year.)

4. Over the years the plant has experienced a number of operational perturbations that have, to varying degrees, impacted its throughput capability. These have included the installation of the LWR head-end facilities and the performance of shakedown operations therein, the removal of a dissolver from the LWR head-end, the construction of the UP2 plant expansion, and the construction of the NPH and TO spent fuel cask unloading facilities.

The details of operation of the UP2 plant are considered proprietary by COGEMA; thus, it is not possible to calculate the availability factor of the plant from published information. However, from the data that are available, it would appear that a plant availability factor of over $80 \%$ has been demonstrated during recent years of operation of the facility, which includes the consideration of annual outages.

The French have been making a concerted effort to reduce radiation exposure to plant workers. The results of their efforts are demonstrated in Fig. 2.44 for the UP2 plant. Exposures were highest during the earlier years of operation and have steadily declined since then. The average annual whole-body dose to personnel has declined from about 450 mrem/year to 156 $\mathrm{mrem} /$ year in 1986, although the amount of fuel processed annually was generally increasing. It should be noted that in France the maximum allowable whole-body occupational exposure is $5 \mathrm{rcm} / \mathrm{year}$. This reduction in dose resulted largely from increases in monitoring activities and in the reduction in frequency, duration, and exposure of personnel in work zones having high-radiation levels.

In the expansion of the UP2 plant (UP2-800) and in the design of the UP3 plant, special efforts have been directed toward improving the reliability of the plants and effecting further reductions in personnel exposure, based on the extensive past experience gained in the design and operation of both the UP1 and UP2 plants. Equipment components that are subject to frequent failure are being modularized for ready removal and installation. Equipment items that require frequent repair are being positioned so that they can be removed and replaced rapidly by MERC systems (see Sect. 2.8.1). Remote maintenance is being maximized. Standardized valves and pumps have been developed for nuclear service which are capable of being rapidly dismantled and maintained with minimum opportunity for contamination. A test bed has been developed for performing cold tests on new equipment items and systems before their installation in the plants to develop standard maintenance methods, to train operators, and to demonstrate equipment and system reliability. 


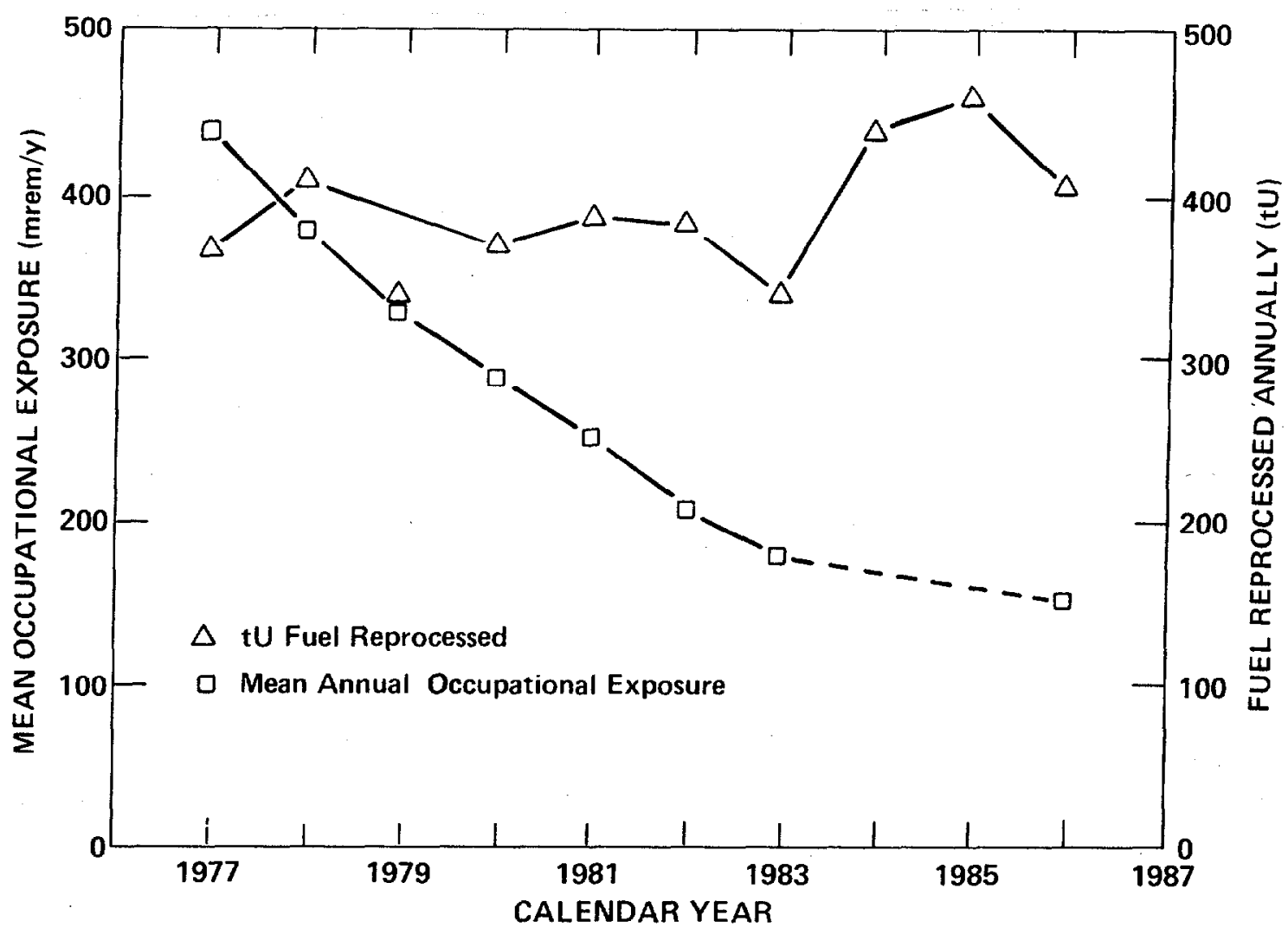

Fig. 2.44. UP2 reprocessing and personnel exposure history.

\subsubsection{British Reprocessing Experience}

The British reprocessing experience roughly parallels the reprocessing experience in France. The United Kingdom reprocessing plant at Sellafield has been reprocessing gas-cooled reactor (magnox and AGR) fuel over 25 years. A small research and development facility was added to develop the technology for reprocessing LWR fuels. The Thermal Oxide Reprocessing Plant (THORP) is being constructed on the Sellafield site and is scheduled to start operation in 1990. The THORP is designed to reprocess 1200 tU/year of domestic and foreign LWR fuels. Additionally, a new fuel handling plant at the Sellafield site went into operation in January 1986 to provide receiving, pool storage, and decanning services. The central feature of this facility is the three large storage pools, each holding $6800 \mathrm{~m}^{3}$ of water.

Dose rate statistics were not available for the United Kingdom reprocessing experience, and they will not be engaged in reprocessing LWR fuels until THORP is complete. Like the French, the British have found that unplanned outages caused by equipment failures and the need for contact maintenance in the older parts of the plant are the major causes of lost production and personnel exposure. The THORP will incorporate improved equipment reliability, standardized equipment, and remote maintenance features. 


\subsection{REFERENCES FOR SECTION 2}

1. G. Goldschmidt, The Atomic Complex, American Nuclear Society, La Grange Park, IL (1982).

2. P. Henry, "Exposition Professionelle dans les Usines de Retraitement, Radioprotection 21 (3), 213-229, (1986), ORNL/TR-87/17.

3. Commissariat a 1'Energie Atomique, French Industrial Experience in Radioactive Waste Management, Decommissioning, and Spent Fuel Storage, Saclay (October 1986).

4. B. Lenail and H. W. Curtis, "Transport of Irradiated Fuel to the La Hague Reprocessing Plant," pp. 1490-1494 in PATRAM '83 Seventh International Symposium on Packaging and Transportation of Radioactive Materials May 15-20, 1983, New Orleans, CONF-830528.

5. B. Lenail, "Spent Fuel Transport in and to France, Nuclear Europe, 5/1984, pp. 17-19.

6. A. Salmon, "The Transportation of Radioactive Waste - A Review," pp. 387-396 in Waste Management '87, Vol. 1 - General Interest, University of Arizona, Tuscon, AZ (1987).

7. E. R. Johnson Associates, Inc., private communications with SGN and NUMATEC, Inc. personnel (1987).

8. C. A. Hutchison and P. Lemaistre, "Large-Scale Spent Fuel Cask Reception and Dry Unloading at La Hague," pp. 581-583 in Waste Management '87, Vol. 1 - General Interest, University of Arizona, Tuscon, AZ (1987).

9. P. L. Chometon and J. S. Ricaud, "Industrial Aspects of Spent Fuel Storage," pp. 875-890 in Proc. Int. Conf. Nucl. Power Experience, IAEA, Vienna (1982).

10. P. L. Chometon, "The French Spent Fuel and HLW Storage Program," Spent Fuel Storage Seminar, Washington, D.C. (January 1985), Institute of Nuclear Materials Management Northbrook, IL 60062.

11. P. L. Chometon and P. Cantin, "Centralized Disposal of Spent Fuel Elements in France," Nuclear Europe 2/1983, pp. 12-15.

12. GEC Reactor Equipment Ltd., Outline of Design Study on the Dry Storage of LWR fuel for Tennessee Valley Authority, 1981.

13. E. O. Maxwell and D. Deacon, "Operating Experience of Vault Type Dry Storage and Its Relevance to Future Storage Needs," Proc. NEA Specialist Workshop, Madrid, May 11-13, 1982, OECD, Paris.

14. D. Deacon and D. J. Wheeler, "Engineering and Safety Features of Modular Vault Dry Storage," Workshop on Irradiated Fuel Storage, Toronto, October 1984.

15. GEC Reactor Equipment Ltd., Irradiated Dry Fuel Storage, 1980.

16. B. R. Cundhill, "Developing a Smaller Dry Vault," Nuclear Engineering International (December 1985).

17. N. Bradley, G. A. Brown, C. O. Tallamhain, and C. J. Ealing, "Providing Flexibility in Spent Fucl and Vitrified Waste Management," Nuclear Engineering International (October 1986).

18. A. S. Sugier, J. G. Geoffroy, and M. D. Dobremelle, "Dry Storage of Spent Fuel Elements," pp. 89-100 in Proc. NEA Specialist Workshop, Madrid, May 11-13, 1982, OECD, Paris. 
19. C. Bernard and F. Chenevier, "Maintenance in a Commercial Reprocessing Facility," pp. 2-389 thru 2-393 in Proc. Meet. Fuel Reprocessing and Waste Management, August 26-29, 1984, Jackson, Wyoming, American Nuclear Society, La Grange Park, IL 60525.

20. P. B. Laurent and R. J. Richter, "Remote Handling Concepts for the UP3 Fuel Reprocessing Plant," pp. 148-155 in Proc. Int. Conf. Robotics and Remote Handling Nucl. Ind., September 23-27, 1984, Toronto, Canadian Nuclear Society, Toronto, Canada.

21. F. Bujon, "Reprocessing Commercial Nuclear Fuels: The French Experience," AIF Fuel Cycle Conference, Kansas City, Missouri, March 1983, Atomic Industrial Forum.

22. J. Coutre, Status of the French Reprocessing Industry, COGEMA, Saclay, 1984.

23. C. Aycoberry, Present Status and Prospects for Reprocessing, COGEMA, Saclay, 1985.

24. M. Delange, "Reprocessing of LWR Spent Fuel at La Hague 1976-1982," Nuclear Europe 1/1983, pp. 33-37.

25. M. Astill, "Head-End Remote Handling Systems for the New Thermal Oxide Reprocessing Plant, Sellafield, England, pp. 162-172 in Proc. Int. Conf. Robotics and Remote Handling Nuc. Ind., September 23-27, 1986, Toronto, Canadian Nuclear Energy Society, Toronto, Canada. 


\section{SWEDISH SPENT FUEL AND WASTE HANDLING TECHNOLOGY}

\subsection{INTRODUCTION AND BACKGROUND ${ }^{1.5}$}

Swedish law currently limits nuclear power production to that which is gencrated by the 12 existing light-water reactors having a combined installed capacity of $9650 \mathrm{MW}$ (e) (Fig. 3.1). According to a parliamentary decision, none of these reactors is to be operated beyond the year 2010. The law furthermore places the primary responsibility for operational safety, waste management, and decommissioning on the owners of the nuclear plants. As a consequence of this situation, the affected four power companies assigned to their jointly owned Swedish Nuclear Fuel and Waste Management Company, SKB (Svensk Karnbranslehantering AB), the

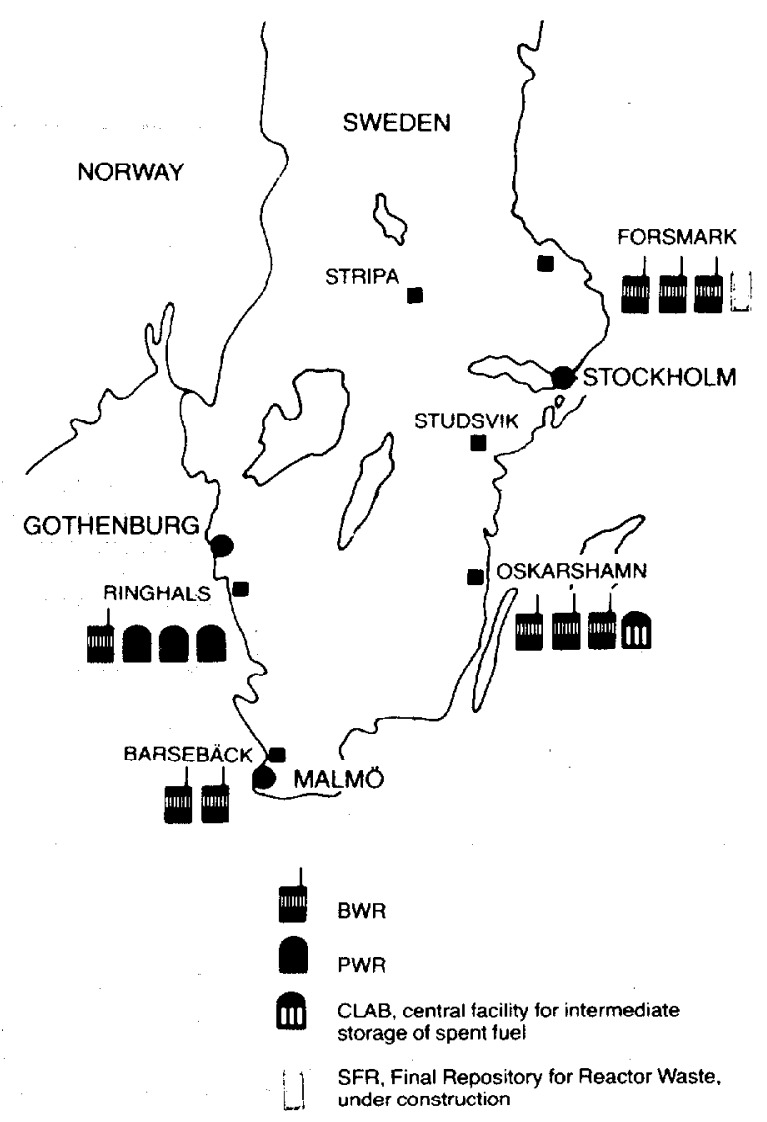

Fig. 3.1. The Swedish nuclear power program (Ref. 1). 
responsibility for planning, constructing, and operating all the facilities required for the management of the radioactive wastes that arise from this prescribed economy.

An overall waste management strategy was formulated by SKB based on the projected generation of $1900 \mathrm{TWh}$ of electricity through the year 2010 and on the direct disposal of spent fuel without reprocessing (Fig. 3.2). In accordance with this strategy, short-lived wastes are disposed of promptly, but an interim storage period of 30 to 40 years is planned before the disposal of spent fuel and other long-lived materials. This storage is provided by a central interim storage facility for spent fuel, CLAB, which has been in operation at Oskarshamn since July 1985. Although the CLAB's storage capacity is presently limited to $3000 \mathrm{tU}$, as spent fuel, it is nevertheless capable of being expanded to accommodate the total anticipated Swedish needs of about 7800 tU. After storage at the CLAB, the spent fuel and reactor core components will be packaged in corrosion-resistant containers and deposited in a final repository for long-lived waste (SFL), to be located deep in crystalline rock. Since fuel packaging and disposal are not required until around 2020, additional research and development will be devoted over the next decade or so to the design and siting of these later facilities.

Before the law phasing out nuclear energy was enacted, SKB and the Swedish utilities concluded agreements with French and British companies for reprocessing about 870 tU. To avoid the necessity of constructing additional facilities for handling the relatively small quantity of vitrified high-level reprocessing waste that would be returned to Sweden, SKB has divested itself of all but $140 \mathrm{tU}$ of these reprocessing contracts.

A final repository for low- and medium-level waste from reactor operations (SFR) is being built off-shore from the Forsmark nuclear power station. It is located in crystalline rock, $60 \mathrm{~m}$ below the seabed. Under construction since 1983, the SFR is scheduled to begin operation in

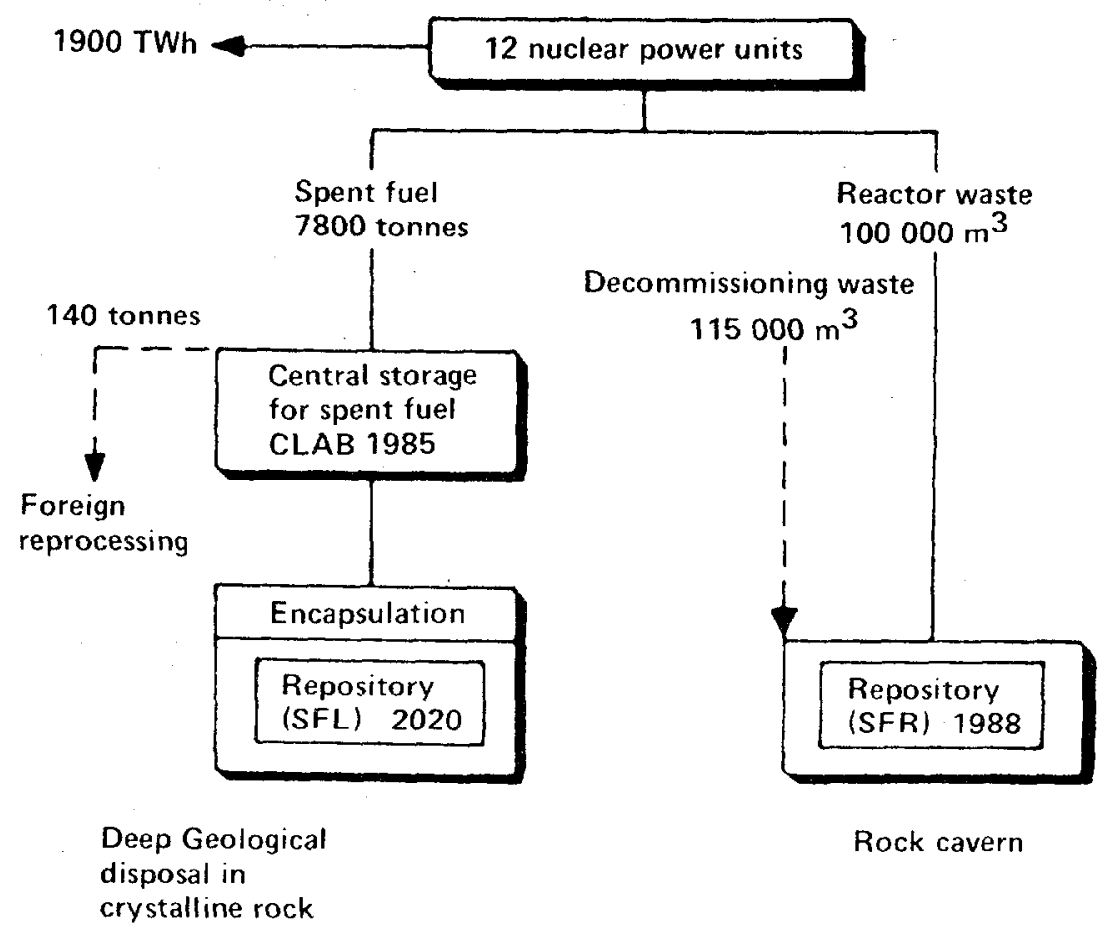

Fig. 3.2. Swedish waste management strategy (Ref. 1). 
1988 and should contain about $100,000 \mathrm{~m}^{3}$ of waste by 2010 . Later excavations at this site will be designed to allow for an additional $115,000 \mathrm{~m}^{3}$ of waste that is expected to arise from decommissioning of all nuclear facilities.

To take advantage of the coastal locations of the Swedish industrial nuclear energy facilities, a sea transportation system for spent fuel and other radioactive materials was acquired. It has been in operation with spent fuel since 1983 and consists of a specially designed ship, fuel transport casks, and terminal transport vehicles which convey the fuel shipping casks between the reactor storage basins, the ship, and the CLAB. Beginning in 1988, the same ship and similar land vehicles will be used to transport reactor waste to the SFR.

In the remainder of this scction, the transportation system, the CLAB, and the SFR will be described in more detail. Also the operating experience acquired through 1986 with the transport system and at the CLAB will be reviewed.

\subsection{SPENT FUEL AND WASTE TRANSPORT SYSTEM ${ }^{6-11}$}

Since all of the Swedish power plants are located with harbors along the coast, and plans had been made to similarly site the CLAB and the SFR, a transportation system based on sea transport was clearly indicated. The system presently consists of the following:

1. a specially designed ocean ship, the M/S Sigyn;

2. ten transport casks and auxiliary equipment for spent fuel;

3. two transport casks for reactor core components; and

4. three specially designed vehicles for short-distance transport of casks at shipment terminals.

\subsubsection{The Vessel, M/S Sigyn}

The M/S Sigyn (Fig. 3.3) was designed in Sweden, built by a French shipyard, and delivered to its owners in October 1982. She is a twin-screw, combined roll on-roll off/lift on-lift off (ro-ro/lo-lo) ship, which means that cargo can either be handled by means of vehicles using a stern ramp or with cranes through cargo hatches. Designed for worldwide operation, Sigyn was built to comply with Swedish and French regulations and is classified for operation in ice. She has a double hull, double bottom, and several watertight bulkheads, ensuring very high buoyancy. The propulsion machinery consists of two independent systems, and electric power is provided by three generators, each capable of supplying the ship's total demand.

The single hold has a length of $57 \mathrm{~m}$, a free breadth of $10 \mathrm{~m}$, and a free height of $5.6 \mathrm{~m}$. It can accommodate ten, TN $17 / \mathrm{Mk} 2$ spent fuel transport casks with a gross weight of $80 \mathrm{t}$ each, or an equal number of reactor waste transport containers, each weighing up to $120 \mathrm{t}$ loaded. Two hatchways that are $25 \mathrm{~m}$ long are closed by a set of covers, each consisting of two pairs of hydraulically actuated end-folding panels. Ro-ro access is provided by a stern ramp having a total length of $16 \mathrm{~m}$ and a roadway of $10 \mathrm{~m}$. A top-hinged, watertight stern door provides a clear opening $10 \mathrm{~m}$ wide by $5.75 \mathrm{~m}$ high.

Radiation shielding for the crew is provided by 9-m-thick transverse water tanks across the forward end of the cargo hold. There are also 150-mm-thick concrete shields between the hold and the machinery spaces in the wings. Radiation measurement instruments are provided in the hold and the engine rooms, and water and air samples can be analyzed for radioactivity in the ship's laboratory.

Additional specifications are provided in Table 3.1. 


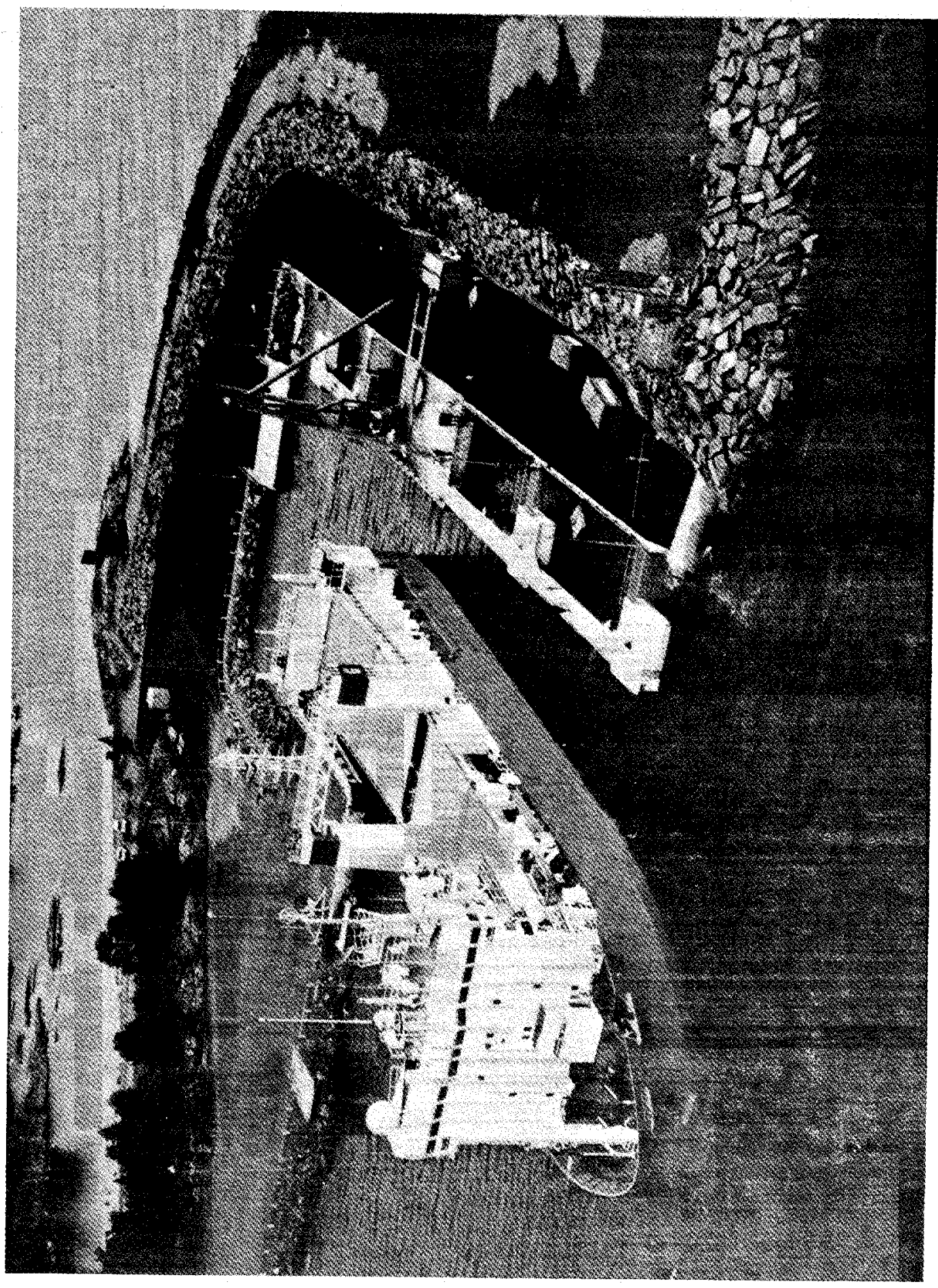

㲾 
Table 3.1. Selected data on the M/S Sigyn

\begin{tabular}{ll}
\hline Length, overall & $90.6 \mathrm{~m}$ \\
Breadth & $18.0 \mathrm{~m}$ \\
Depth & $6.7 \mathrm{~m}$ \\
Draught, fuel loaded & $4.0 \mathrm{~m}$ \\
Deadweight, max. & $2044 \mathrm{t}$ \\
Cargo capacity & $1200 \mathrm{t}$ \\
Machinery output & $2 \times 993 \mathrm{~kW}$ \\
Speed & $12 \mathrm{knots}$ \\
Cruising range & $23 \mathrm{~d}$ or about 6000 nautical \\
& miles \\
\hline
\end{tabular}

\subsubsection{Spent Fuel Shipping Casks}

The cask used to transport spent fuel is the TN 17/Mk2, developed by Transnucleaire in France and licensed by French and Swedish authorities (Fig. 3.4). It is designed for transport of spent BWR and PWR fuel assemblies having a total heat generation rate of up to $43.5 \mathrm{~kW}$. Its capacity is 7 PWR or 17 BWR assemblies, equivalent to a payload of about $3.2 \mathrm{tU}$, and it has a total weight of $80 \mathrm{t}$ when loaded. Shipments are dry with the cask cavity filled with nitrogen gas during transport. The cask has the following features:

- forged steel body with stainless steel overlay;

- copper fins for heat dissipation, brazed to the steel body;

- a neutron shield at the base of the fins consisting of a resin compound;

- a lid system consisting of a shielding plug and plug cover,

- removable insert (basket) with neutron poisoning characteristics;

- shock absorbing covers at the ends; and

- lifting trunnions.

Of the ten casks presently in use, seven were manufactured in Sweden and three were made in Japan. In addition, two special casks (TN 17/CC) have been acquircd for shipping reactor core components. They are a simplified version of the TN 17/Mk2 without the cooling fins and neutron shielding and are used for shipping BWR fuel channels, boron neutron absorbers, and control rods.

\subsubsection{Terminal Transport System}

Transport of the spent fuel and core components casks between the power plants, the M/S Sigyn, and the CLAB is carried out with a specifically designed terminal vehicle - a self-propelled 12-axle transporter (Fig. 3.5). This vehicle is $12.3 \mathrm{~m}$ long, $3.3 \mathrm{~m}$ wide, and weighs $28 \mathrm{t}$. It has a capacity of $115 \mathrm{t}$ and a maximum speed of $10 \mathrm{~km} / \mathrm{h}$. Each cask has its own transport 


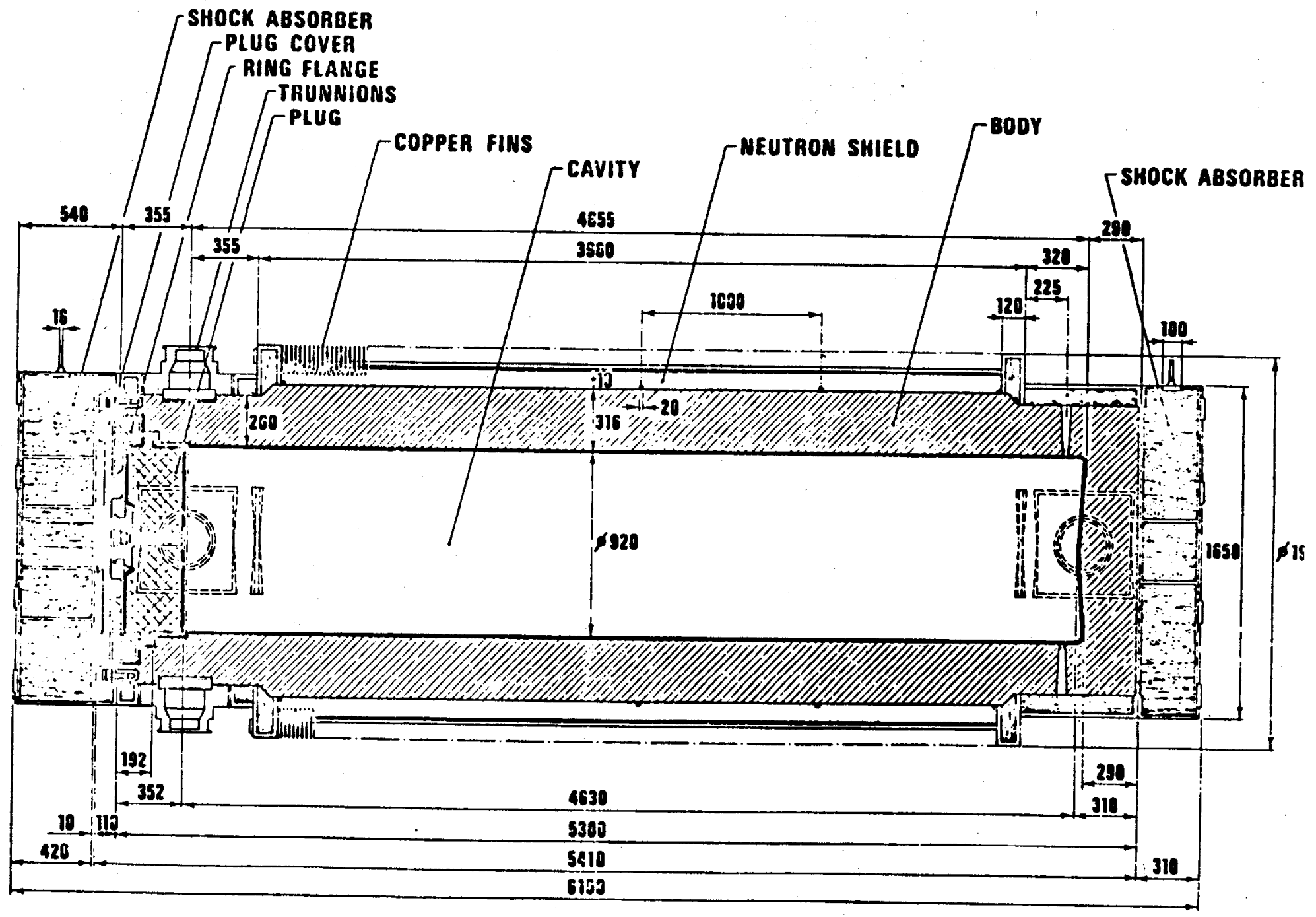

Fig. 3.4. Transport cask TN 17/Mk2 (Ref. 12). 


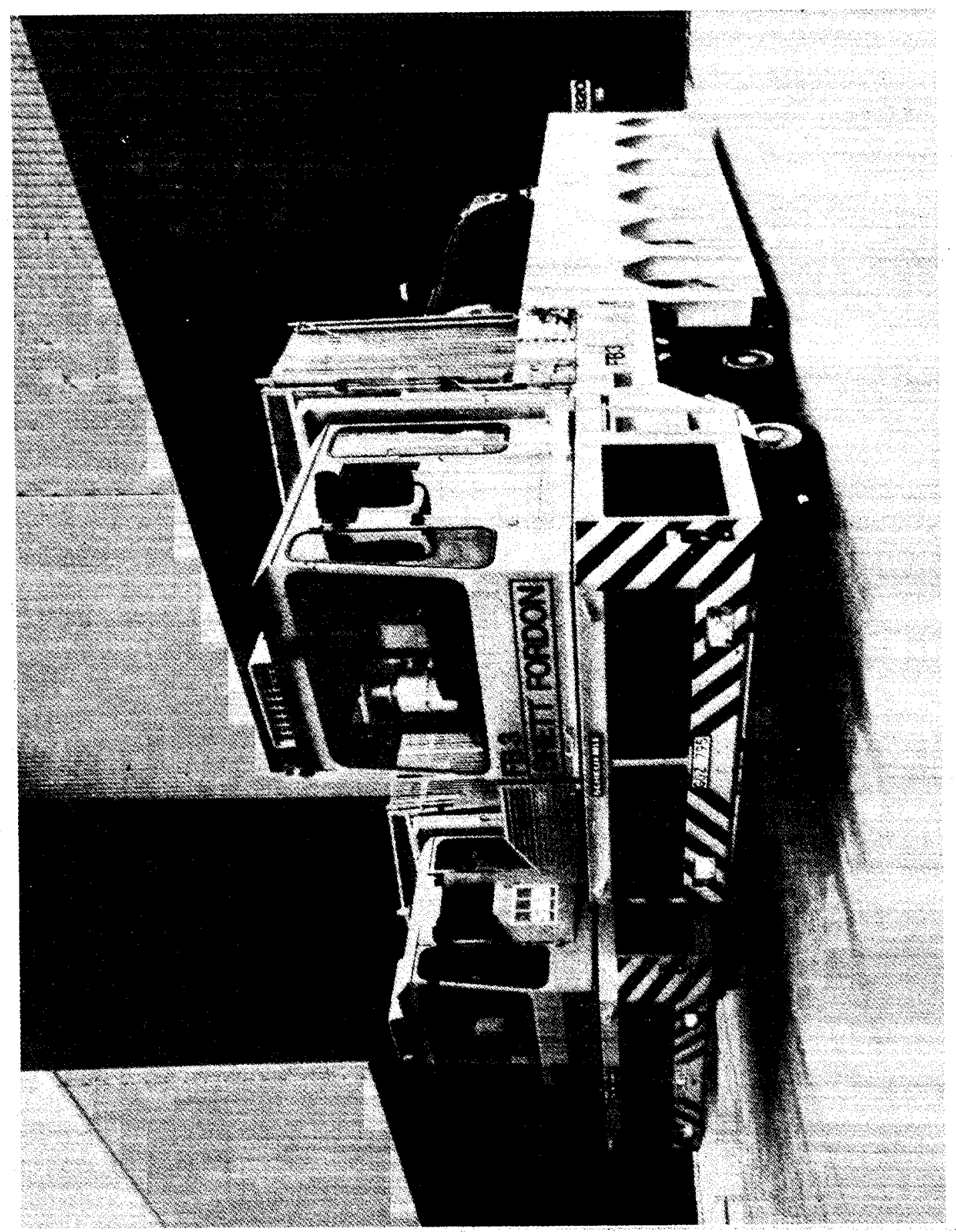


frame which is used for land and ship transport, as well as for temporary storage. After the cask has been fastened to its frame, the vehicle is positioned under the assembly and lifts it hydraulically into the driving position for transfer aboard the ship via the aft ramp. On board, the cask on its frame is placed in one of ten fixed positions and secured to the cargo deck (Fig. 3.6). After all the casks are loaded, the vehicle normally remains within the ship for use later at the CLAB or at other power plants. Upon arrival at Simpevarp harbor, this same system is used to transfer the casks from the ship into the CLAB's reception area.

\subsubsection{Operational Experience}

The transportation system was inaugurated in January 1983, and in the course of that year $57 \mathrm{t}$ of uranium as spent fuel were transported from Swedish reactors to La Hague (Cherbourg) in six shipments aboard the M/S Sigyn. From mid-1985 through August 1987 about 500 t of spent fuel were transferred to the CLAB, corresponding to more than 1200 (mostly BWR) fuel assemblies. In all, 20 scheduled shipments comprising 82 casks were made to the CLAB during this 11-month period, and 13 casks filled with BWR fuel channels were also received. This is about the nominal design rate of fuel reception for the CLAB (300 tU/year in 100 cask shipments).

To initiate a fuel shipment, about five of the total inventory of ten spent fuel casks are delivered to a power plant. They are loaded with fuel in 8 to 12 days and then returned by ship to the CLAB. In the meantime, the five casks used in a previous delivery have been emptied at the CLAB and made ready for a return shipment. Thus, immediately after unloading, a complement of empty casks can be loaded and the ship made ready to sail. One terminal vehicle at the power plant and at least one vehicle at the CLAB must be kept available in order for this schedule to be maintained.

Presently, one shipment every two weeks is scheduled. This results in a round-trip time for each cask of four to five weeks, or about ten round-trips a year. Since the average time at sea is about $24 \mathrm{~h}$ in each direction, the ship utilization is small compared to the total cask handling time.

The series of cask handling operations that are required to move the spent fuel from power plants to the CLAB are reported to have worked well. Each shipment is carefully planned and scheduled, and responsibility for the casks and their documents is delegated to specific individuals during each step. The radiation doses to the ship's crew are evaluated once a month and have thus far been below the limit of detection. However, the fuel shipped thus far has been of a relatively low burnup and well-aged (four to five years out of reactors), resulting in cask tcmperatures and surface dose rates far below the design values. For example, typical heat generation rates were 2 to $14 \mathrm{~kW}$ (compared to the design value of $43.5 \mathrm{~kW}$ ), and surface dose rates were in the range of 0.03 to $0.15 \mathrm{mSv} / \mathrm{h}$ (compared to $2 \mathrm{mSv} / \mathrm{h}$ ). Contaminated areas have been found occasionally on the cask surfaces that have yielded smear test readings greater than 40 $\mathrm{kBq} / \mathrm{m}^{2}$. Surface temperatures during transport have been around $30^{\circ} \mathrm{C}$.

The time required for transportation with the ship is well below the ship's capability. When shipments of reactor waste to the SFR begin in 1988, utilization will increase to about 35 voyages annually, but even this rate is not expected to pose a scheduling problem.

\subsection{CENTRAL STORAGE FACILITY FOR SPENT FUEL - CLAB11-17}

When the decision was made in the late 1970 s to construct an interim fuel storage facility for use beginning in 1985, it was acknowledged that the licensing and scheduling requirements would constrain the design to proven technology. Therefore, this technology was then limited to 


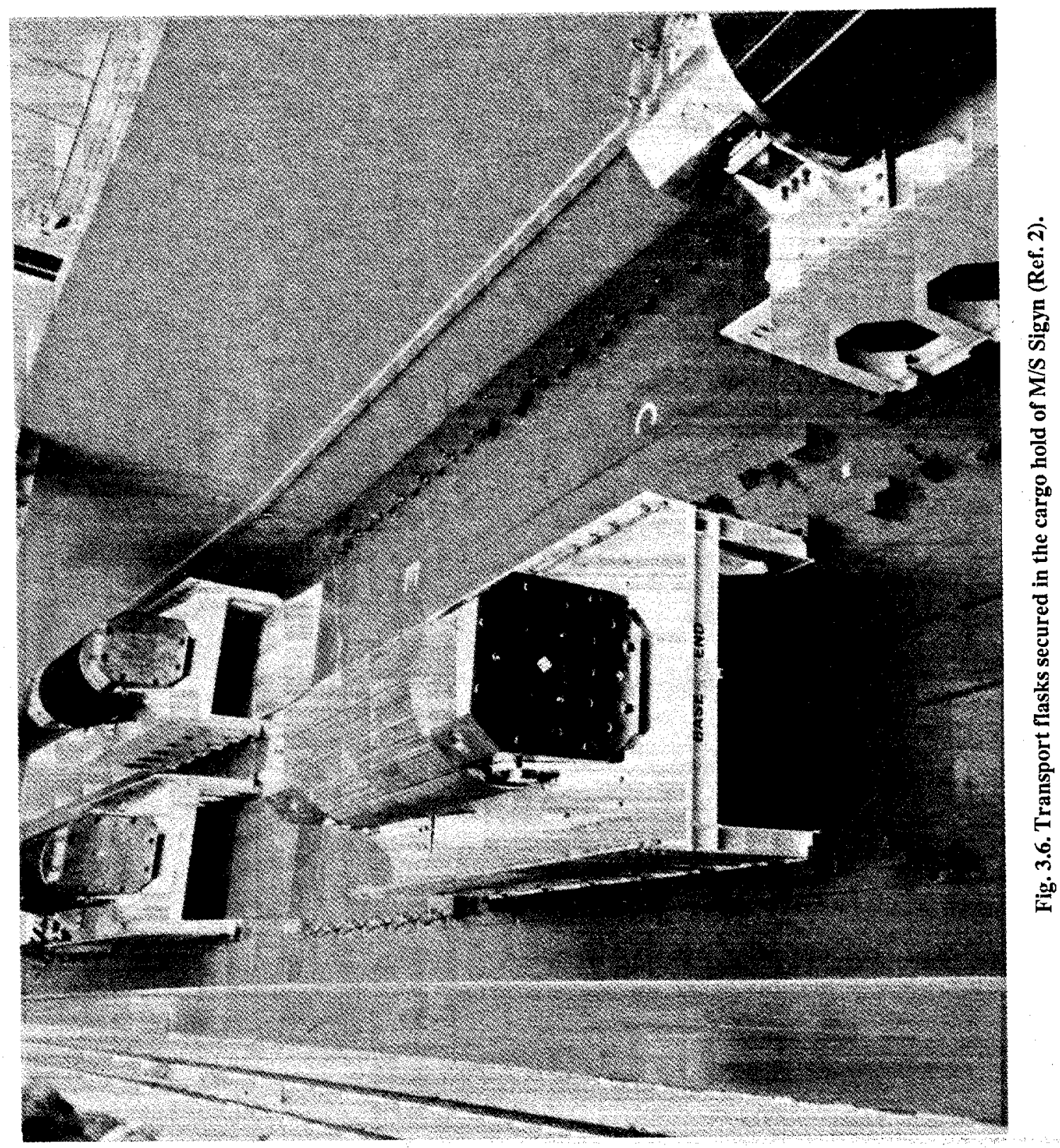


storage under water. Also, authorities recommended that the storage facilities be located underground for protection against such potential impacts as acts of war, sabotage, and extreme natural conditions.

Following a 20 -month licensing process, a construction project was organized by SKB who, as owner and licensee, maintained an overall supervision and management function. OKG Aktiebolag (OKG AB), owner of the Oskarshamn power station and one of SKB's sharcholders, was given responsibility for the buildings and storage area, for safety reviews, and for quality assurance. OKG was also chosen as the future operator of the CLAB. Asea-Atom (AA) had the responsibility for design, layout, and installation of all major process and handling systems, as well as for the computer control and electrical systems. Societe Generale pour les Techniques Nouvelles (SGN) was made responsible for the cask reception systems: transfer, cooling, unloading, remote maintenance, and decontamination. Finally, the Swedish State Power Board assumed a number of major responsibilities in the areas of design and documentation.

Site preparation was started in May 1980 on the Simpevarp peninsula near the Oskarshamn nuclear power station. In addition to being in an area of low seismicity, this site provided a number of other advantages such as access to a common harbor, access to Oskarshamn's interim storage facility for low- and medium-level waste, and access to central workshops. The first cask of spent fuel was received at the CLAB in 1985.

The construction cost is reported to have been about SEK 1700 million $\mathbf{\$} 234$ million in 1985), of which $25 \%$ was for design, engineering, and project management, $37 \%$ was for mining and buildings, and $38 \%$ was for equipment. The annual operating cost is given as about $\$ 9$ million.

\subsubsection{General Description}

The CLAB consists of both surface and subsurface facilities (Fig. 3.7). The above-ground complex is composed of the reception building where incoming casks of spent fuel and reactor corc components are reccived, unloaded, and prepared for return shipment, and buildings for auxiliary systems (water cooling and purification, waste handling, and ventilation), electric power systems, and staff offices. The surface facilities are connected to the underground storage area by two shafts, one for transferring the spent fuel and the second for personnel access, ventilation, and services. Some selected technical particulars are given in Table 3.2.

The design philosophy used at the CLAB was based on an average occupational man-rem commitment of $1 / 10$ the ICRP norms. To achieve that goal, biological shielding is provided around all process systems, and remote operation and maintenance techniques are used. To reduce the impact of potential airbome contamination in the fuel reception building, the air is exchanged as frequently as five times per hour. All handling of bare fuel assemblies is carried out under water depths of 4 to $8 \mathrm{~m}$. Cask handling systems and most process systems are operated from a central computerized control room. The cask cooling system, where the highest levels of radioactivity can be expected to accumulate, is equipped for remote maintenance using shielded casks. Radioactive components and parts are handled by manipulators in hot cell areas. These systems, that were supplied by SGN, are described in more detail in Sects. 2.4 and 2.5.

The reception building has three water-filled pools, two of which are equipped to receive TN 17 casks. The third pool accommodates the fuel leakage detection equipment, and if supplied with the proper equipment can also be used to receive casks other than the TN 17 casks. The design receiving capacity is $300 \mathrm{tU} /$ year, which is equivalent to about 100 spent fuel shipping casks annually. This capacity is based on operating two 8-h shifts for five days each week. 


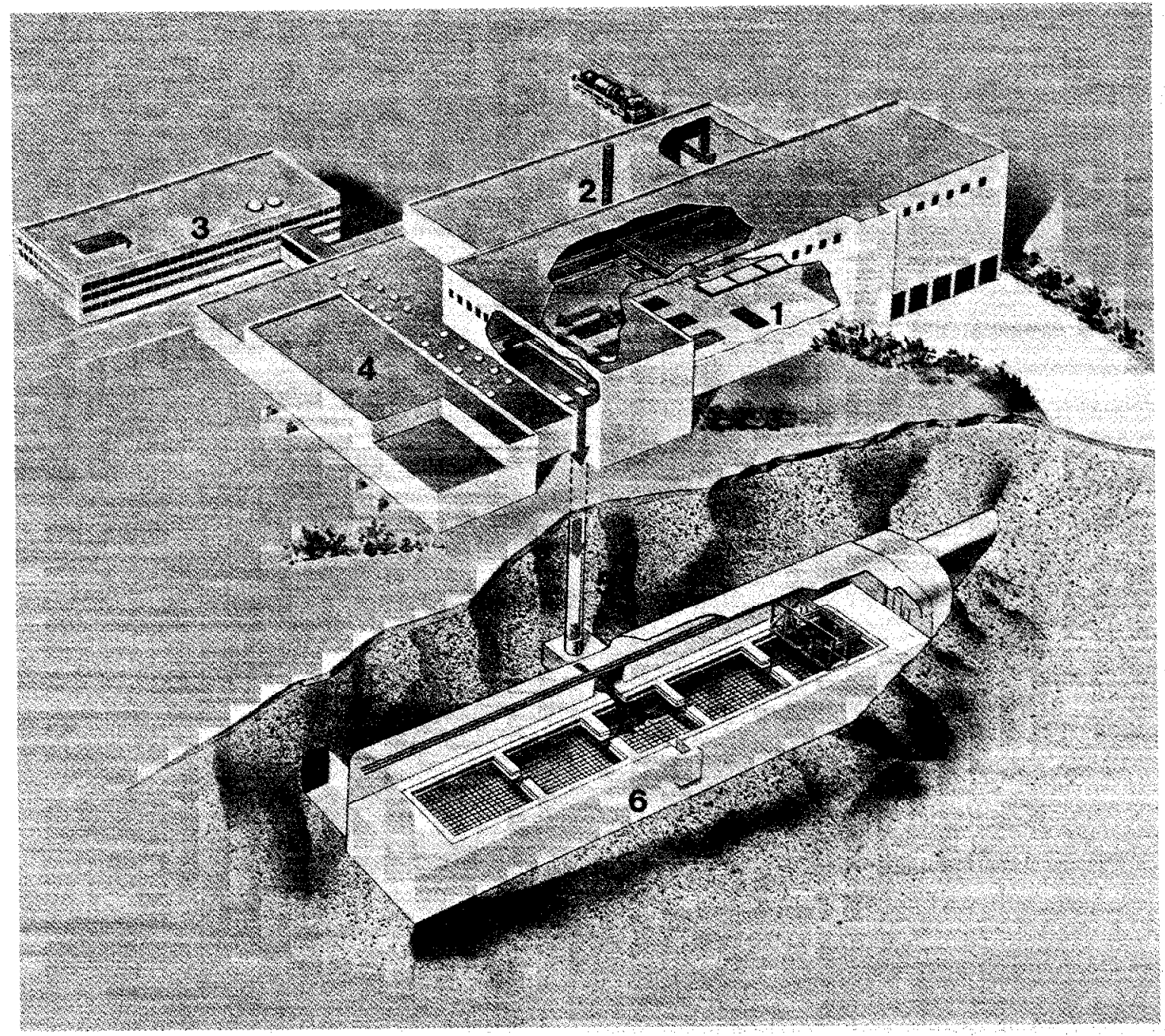

Fig. 3.7. General layout of the CLAB showing (1) the reception building, (2) the building for auxiliary systems, (3) the office building, (4) the electrical building, (5) the fuel elevator, and (6) the fuel storage building. (Ref. 15).

The fuel storage building is located underground in a granite cavern whose ceiling is 25 to $30 \mathrm{~m}$ below ground level. The cavern is $120 \mathrm{~m}$ long, $21 \mathrm{~m}$ wide, and $27 \mathrm{~m} \mathrm{high}$; the walls are covered with shotcrete and are reinforced with rock bolts. There are four storage pools and one smaller central pool which is connected by a water-filled channel to the vertical fuel transfer shaft. Each storage pool contains about $3000 \mathrm{~m}^{3}$ of water and can hold $750 \mathrm{tU}$ of spent fuel. The pools are lined with stainless steel, and a leakage detection system is installed along the welds. The present design provides for the storage capacity to be more than doubled after 1995 to handle the anticipated total Swedish requirements through the year 2010. The water temperature in the storage pools is kept at $30^{\circ} \mathrm{C}$ by cooling with seawater using primary and secondary heat exchanger circuits. Water purity is maintained by filtration and ion exchange treatment. The spent ion exchange resins and filter media from water purification are classified as medium-level wastes. They are immobilized in concrete moulds and stored in OKG's interim storage facility 
Table 3.2. Selected data on the CLAB ${ }^{14}$

Storage capacity

Receiving capacity

Storage pools

Number

Water volume, approximately

Water depth, approximately

Pool design temperature

Operating temperature (at seawater temperature of $18^{\circ} \mathrm{C}$ and decay power of $6.5 \mathrm{MW}$ )

Maximum operating temperature with one cooling circuit in operation
$3000 \mathrm{tU}$

$300 \mathrm{tU} /$ year

$4+1$ in reserve

$3000 \mathrm{~m}^{3} / \mathrm{pool}$

$12.5 \mathrm{~m}$

$100^{\circ} \mathrm{C}$

$32^{\circ} \mathrm{C}$

$45^{\circ} \mathrm{C}$

Cooling and cleaning system for receiving pools

Number of circuits

1

Cooling capacity (at seawater temperature of $18^{\circ} \mathrm{C}$ and pool temperature of $32^{\circ} \mathrm{C}$ )

Cooling and cleaning system for storage pools

Number of circuits

2

Cooling capacity (at seawater temperature of $18^{\circ} \mathrm{C}$ and pool temperature of $32^{\circ} \mathrm{C}$ )

Cooling water flow

$300 \mathrm{~L} / \mathrm{s}$

Buildings

Surface building total volume

$220,000 \mathrm{~m}^{3}$

Storage section, approximate volume

rock cavern

$65,000 \mathrm{~m}^{3}$

tunnels

$15,000 \mathrm{~m}^{3}$

Dimensions of rock cavern

height

$27 \mathrm{~m}$

width

$21 \mathrm{~m}$

length

$120 \mathrm{~m}$

Thickness of rock cover

20 to $30 \mathrm{~m}$

Formwork, approximately

Reinforcement steel, approximately

$150,000 \mathrm{~m}^{2}$

$7,000 \mathrm{t}$

$60,000 \mathrm{~m}^{3}$ 
pending future shipment to the SFR. All other radioactive wastes from the CLAB operations are conditioned in moulds and drums, as necessary, and stored until they can be transported to the SFR.

\subsubsection{Fuel Handling Procedures}

The sequence involved in receiving the loaded casks, unloading them, and placing the fuel in storage is depicted in Fig. 3.8 and described as follows:

1. A terminal vehicle carries the transport cask into the facility through an air-locked passage beneath the floor of the receiving station.

2. The cask is raised to a vertical position and lifted by an overhead travelling crane through an opening in the floor.

3. The crane carries the cask to one of three preparation cells where a watertight metal skirt is attached around the outer surface to protect the fins against damage and contamination. Hoses are then connected to the cask, and the cask and its contents are cooled to room temperature by first circulating water through the annulus between the skirt and cask and then by circulating water through the cask's internal cavity.

4. After having been cooled and filled with water, the cask is lifted by crane out of the preparation cell and lowered onto a transport wagon on the floor of a cask pool.

5. The transport wagon with the cask is moved on tracks under a hatch leading to the unloading pool. The hatch and the lid of the cask are removed by a handling machine.

6. The fuel assemblies are removed from the cask and placed in a storage canister, which forms a unit for subsequent transport and storage within the facility. The canisters are approximately square in cross section, and each contains $16 \mathrm{BWR}$ or 5 PWR assemblies.

7. The loaded canister is moved by the handling machine through a transport channel to the fuel elevator.

8. The canister is placed in a water-filled elevator cage which then lowers the canister through a water lock to the storage building. The elevator shaft itself is not, of course, filled with water.

9. At the level of the storage pools, a handling machine lifts the canister out of the elevator cage and moves it to one of the storage pools via a transport channel.

10. The canister is placed in a predetermined position in the storage pool.

\subsubsection{Operational Experience}

From mid-1983 to June 1985, the CLAB underwent a thorough startup and commissioning program with the objectives of testing the performance of all equipment and systems, training operators and other plant personnel, and verifying operational controls and safety aspects. Approval to begin radioactive operations was given in June 1985 with the granting of temporary 


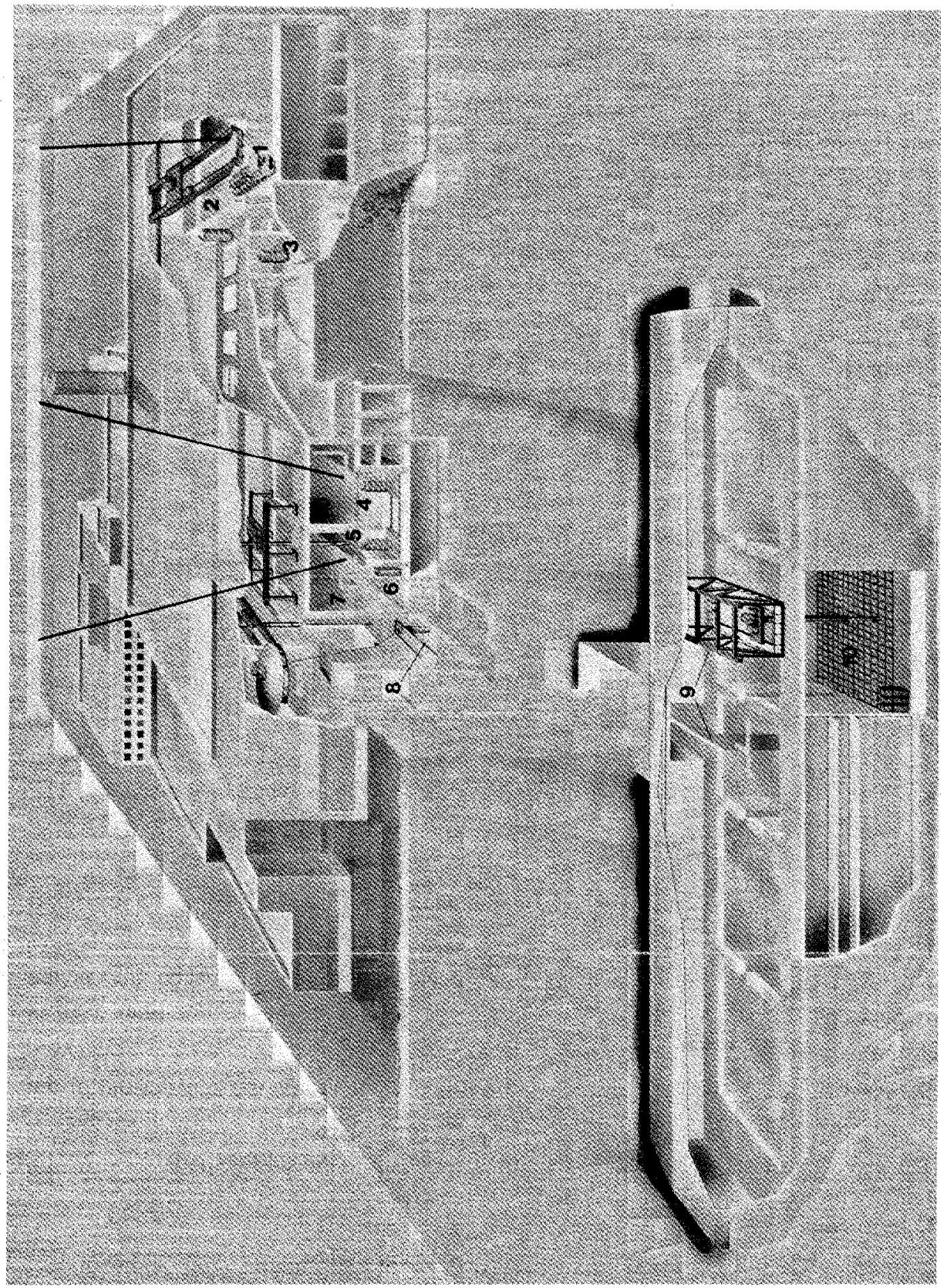


operating licenses that extended through June 1986. During this 12-month period, the spent fuel reception rate was gradually increased until $90 \%$ of the design capacity had been achieved. In addition, several casks containing reactor core components were received.

The results achieved during this initial period of radioactive operation were in keeping with previously established requirements and specifications. Some minor incidents occurred, however, that have necessitated modifications of the Technical Specifications.

1. A minor delay resulted when one transport cask was found to contain ${ }^{85} \mathrm{Kr}$ in its ventilation exhaust, which indicated damaged fuel. Subsequent inspection of the fuel did not reveal any defects, however, and it was handled thereafter as undamaged.

2. A three-week interruption in fuel reception was caused by defective filters in the cask cooling system. Filters of a new design were installed in the system and procedures for back-flushing were modified such that it has since been possible to operate the system at its design capacity without any problems.

3. The desludging filter used in cleaning transport casks after unloading did not function efficiently. Its performance was improved by substituting a filter screen of lower porosity.

Measured occupational radiological doses have revealed nothing that requires correction (Table 3.3). With 75 persons in radiological work, the calculated dose of $276 \mathrm{mmanSv} / \mathrm{year}$ taken from the Safety Analysis Report corresponds to $3.7 \mathrm{mSv} /$ person-year. The measured dose was only $24 \%$ of the expected dose.

The release of radioactivity to the environment has been very small. The total release during 1986 was $3.4 \times 10^{9} \mathrm{~Bq}$ to the water and $2.6 \times 10^{7} \mathrm{~Bq}$ to the air and consisted of about $90 \%$ ${ }^{60} \mathrm{Co}$ and about $10 \%{ }^{54} \mathrm{Mn}$, both of which are activated corrosion products from steel.

\subsection{FINAL REPOSITORY FOR REACTOR WASTE - SFR ${ }^{17-21}$}

As an integral part of Sweden's overall nuclear waste management strategy, SKB chose to establish a final repository for reactor operating waste, known as the SFR, in granite bedrock about $60 \mathrm{~m}$ beneath the Baltic Sea (Fig. 3.9). The total volume of low- and intermediate-level waste from reactor operations through the year 2010 is projected to be $100,000 \mathrm{~m}^{3}$, and an additional 115,000 to $130,000 \mathrm{~m}^{3}$ of waste is expected to be generated thereafter from decommissioning the power plants and associated nuclear facilities. The repository that will eventually contain this material is currently being constructed at a site one kilometer from the harbor at the Forsmark Nuclear Power Plant, off the east coast of Sweden. The hydraulic gradient, and hence the groundwater flow rate, is very low at this subseabed location, and the probability of inadvertent human intrusion is diminished for as long as the site is covered by the sea.

The SFR has different types of disposal chambers depending on the particular type of waste to be emplaced. Medium-level waste representing $40 \%$ of the total waste volume and $90 \%$ of the total radioactivity will be deposited in large concrete silos housed within 70-m-high cylindrical caverns. The silos will be surrounded by a barrier of bentonite, which because of its very low permeability, will help ensure very low release rates of radionuclides to the groundwater. Rock caverns $160 \mathrm{~m}$ long will be used for low-level waste disposal, and the release of radioactivity from these chambers will be governed by the rate of groundwater flow and the low solubility of the waste forms. 
Table 3.3. Comparison of calculated and measured occupational doses (Ref. 11)

\begin{tabular}{lcc}
\hline \multicolumn{1}{c}{ Radiation dose } & $\begin{array}{c}\text { Calculated dose } \\
\text { (mmanSv/year) }\end{array}$ & $\begin{array}{c}\text { Measured dose } \\
\text { in 1986 (mmanSv) }\end{array}$ \\
\hline Transport of cask from ship to the CLAB & 3 & $<1$ \\
Handling of cask in the CLAB & 105 & 26.8 \\
Transport of fuel to storage & 3 & $<1$ \\
Handling of core components & 11 & $<1$ \\
Radiological protection & & 9.0 \\
Miscellaneous (waste treatment, & 154 & 30 \\
maintenance, etc.) & & 65.8 \\
$\quad$ Total & 276 & \\
\hline
\end{tabular}

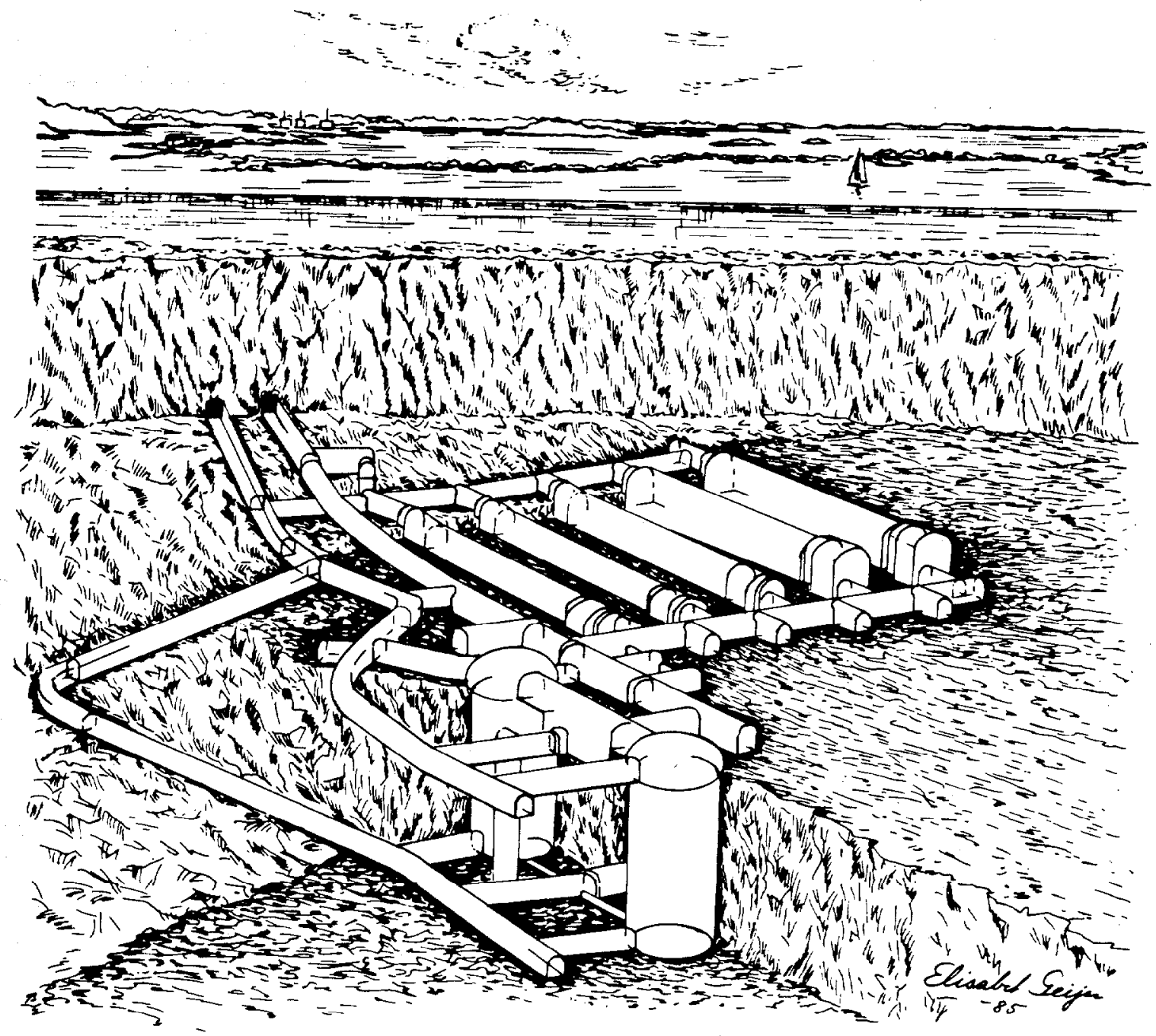

Fig. 3.9. Layout of tunnels and caverns in the SFR (Ref. 18). 
The repository is being built in phases. The first phase, begun in October 1983 and duc to be completed in 1988 , consists of surface facilities at the harbor, two tunnels from the harbor to the area of the caverns and one silo and four rock caverns for the disposal of $60,000 \mathrm{~m}^{3}$ of waste. One of the tunnels will be used for waste transport and services; the other will serve principally for construction, but it can also be used as a backup for waste transport in the event of operational problems. Vattenfall (Swedish State Power Board) is responsible for the design and construction of Phase 1. Phase 2, consisting of a second silo and one or two additional rock caverns, should be complete by the year 2000 and will increase the disposal capacity to about $100,000 \mathrm{~m}^{3}$. It will be possible to increase the disposal capacity even further by adding silos and rock caverns as needed for wastes of the more distant future, such as those from decommissioning.

\subsubsection{Waste Categories and Transport System}

The medium-level waste that will be disposed of in the SFR consists principally of ion-exchange resins and filter material from various water treatment systems. Low-level waste ranges from contaminated reactor components and equipment to incinerator ash and general trash. These wastes are conditioned at the nuclear power stations and packaged for shipment to the SFR as shown in Table 3.4. The resins normally contain most of the radioactivity and are usually solidified in cement of bitumen in cubical concrete moulds or in 200-L steel drums. Less active resins from condensate cleanup are dewatered and packaged in large, transportable concrete tanks.

Virtually all of the reactor operating waste, except that generated at the Forsmark plant, will be transported to the SFR by sea in shielded transport containers using the M/S Sigyn. Low-level waste that does not require shielding will be shipped by road in conventional 3- and 6-m freight containers. Several types of shielded containers are planned, and the total number to be acquired will be about 50. All will be made of steel and will have wall thicknesses ranging from 80 to $130 \mathrm{~mm}$, as needed for the type of waste to be shipped. ${ }^{18}$ The gross (loaded) weight of the containers will be limited to $120 \mathrm{t}$, and they will contain up to 96 drums, 16 concrete moulds, or 3 concrete tanks. The Sigyn will arrive at the Forsmark harbor about 10 times a year carrying

Table 3.4. Characteristics of medium- and low-level wastes

\begin{tabular}{llcr}
\hline \multicolumn{1}{c}{ Waste package } & $\begin{array}{c}\text { Dimensions } \\
\mathrm{L} \times \mathrm{W} \times \mathrm{H}(\mathrm{m})\end{array}$ & $\begin{array}{c}\text { Maximum } \\
\text { surface dose } \\
\text { rate }(\mathrm{mSv} / \mathrm{h})\end{array}$ & $\begin{array}{c}\text { Maximum } \\
\text { weight }(\mathrm{t})\end{array}$ \\
\hline $\begin{array}{l}\text { Concrete moulds with resins solidified } \\
\text { in cement }\end{array}$ & $1.2 \times 1.2 \times 1.2$ & $<30$ & 4.0 \\
$\begin{array}{l}\text { Steel containers with resins solidified in } \\
\quad \text { cement }\end{array}$ & $1.2 \times 1.2 \times 1.2$ & $<500$ & 4.0 \\
$\begin{array}{l}\text { Concrete tanks with dewatered resins } \\
\text { Drums with bituminized resins }\end{array}$ & $3.3 \times 1.3 \times 2.3$ & $<10$ & 20.0 \\
Drums with resins solidified in cement & $0.6 \phi \times 0.9$ & $<500$ & 0.5 \\
Drums with trash and metal scrap & $0.6 \phi \times 0.9$ & $<30$ & 0.5 \\
Miscellaneous containers & $0.6 \phi \times 0.9$ & $<0.3$ & 0.5 \\
\hline
\end{tabular}


up to 10 transport containers on each voyage. Including the shipments of reactor waste from the Forsmark plant, about 150 shielded transport containers will arrive at the SFR every year.

The special vehicle that will be used for waste transport at the SFR and between the harbor, the SFR, and the Forsmark power station is very similar to the terminal vehicles used to carry spent fuel casks and described in Sect. 3.2.3. The vehicle has seven axles with 28 wheels, is diesel powered above ground and electrically powered and remotely operated in the tunnels and repository areas, its maximum velocity is about $3 \mathrm{~km} / \mathrm{h}$ underground and 10 to $14 \mathrm{~km} / \mathrm{h}$ above ground, and its total (loaded) weight will be about $155 \mathrm{t}$.

\subsubsection{Design and Layout}

The layout of the surface facilities (Fig. 3.10) was largely determined by such factors as the layout of the existing harbor area, the location and direction of various accesses, transport requirements, and possible future extensions. The main buildings on the site are the office and workshop building with offices, workshop, storeroom, and garages; the terminal building with a capacity for storage of 12 loaded transport containers; and the ventilation building, located above the tunnel entrances, which houses the repository ventilation, heating, and electrical switching systems.

The layout of the repository tunnels and caverns that are included in Phase 1 construction is shown in Fig. 3.11. The size of the operating (transport) and construction tunnels was determined mainly by transport requirements, but they were also used for services such as ventilation ducts and electrical cables. The operating and construction tunnels are each more than $1000 \mathrm{~m}$ long, and they are $60 \mathrm{~m}^{2}$ and $50 \mathrm{~m}^{2}$ in cross section, respectively. The free area in the operating tunnel is $5.2 \mathrm{~m}$ high by $5.0 \mathrm{~m}$ wide, which is adequate since the transport vehicle with a waste container requires a height of about $4.5 \mathrm{~m}$ and a width of $3.5 \mathrm{~m}$. The tunnel system is designed so that all water inleakage can be collected at only two points: one at the main level and one at the bottom level of the silo.

All waste handling equipment is remotely controlled from the operating area that is located in a small rock cavern within the operating tunnel. This area also contains an office and service rooms for personnel. There are other areas in a separate cavern for electrical and ventilation equipment and maintenance shops for mechanical equipment. The total cost of Phase 1, in money of January 1986 value, is estimated to be SEK 700 million (about $\$ 100$ million).

\subsubsection{Silo repository}

The silo repository is a cylindrical rock cavern $70 \mathrm{~m}$ high by $30 \mathrm{~m}$ in diameter that contains a concrete silo $53 \mathrm{~m}$ in height and $27.5 \mathrm{~m}$ in diameter (Fig. 3.12). The silo rests on a bed of $10 \%$ bentonite and $90 \%$ sand, and the space between the walls of the silo and rock is filled with uncompacted bentonite. The inside of the silo is divided into vertical cells that extend from top to bottom. Fifty-seven of these cells are $2.5 \mathrm{~m}$ by $2.5 \mathrm{~m}$ in cross section, and 12 cells are $1.2 \mathrm{~m}$ by $2.5 \mathrm{~m}$.

The emplacement of waste packages is a fully remote operation. A transport vehicle delivers a shielded containcr filled with waste packages to an unloading position where the container lid is removed by an overhead traveling crane. The packages are then unloaded by a railbound transport wagon located in the emplacement tunnel above the unloading area. The wagon moves the package over to its cell in the silo, lowers it into place, and returns to the unloading station for the next transfer. Four concrete moulds or 16 drums can be handled in one 


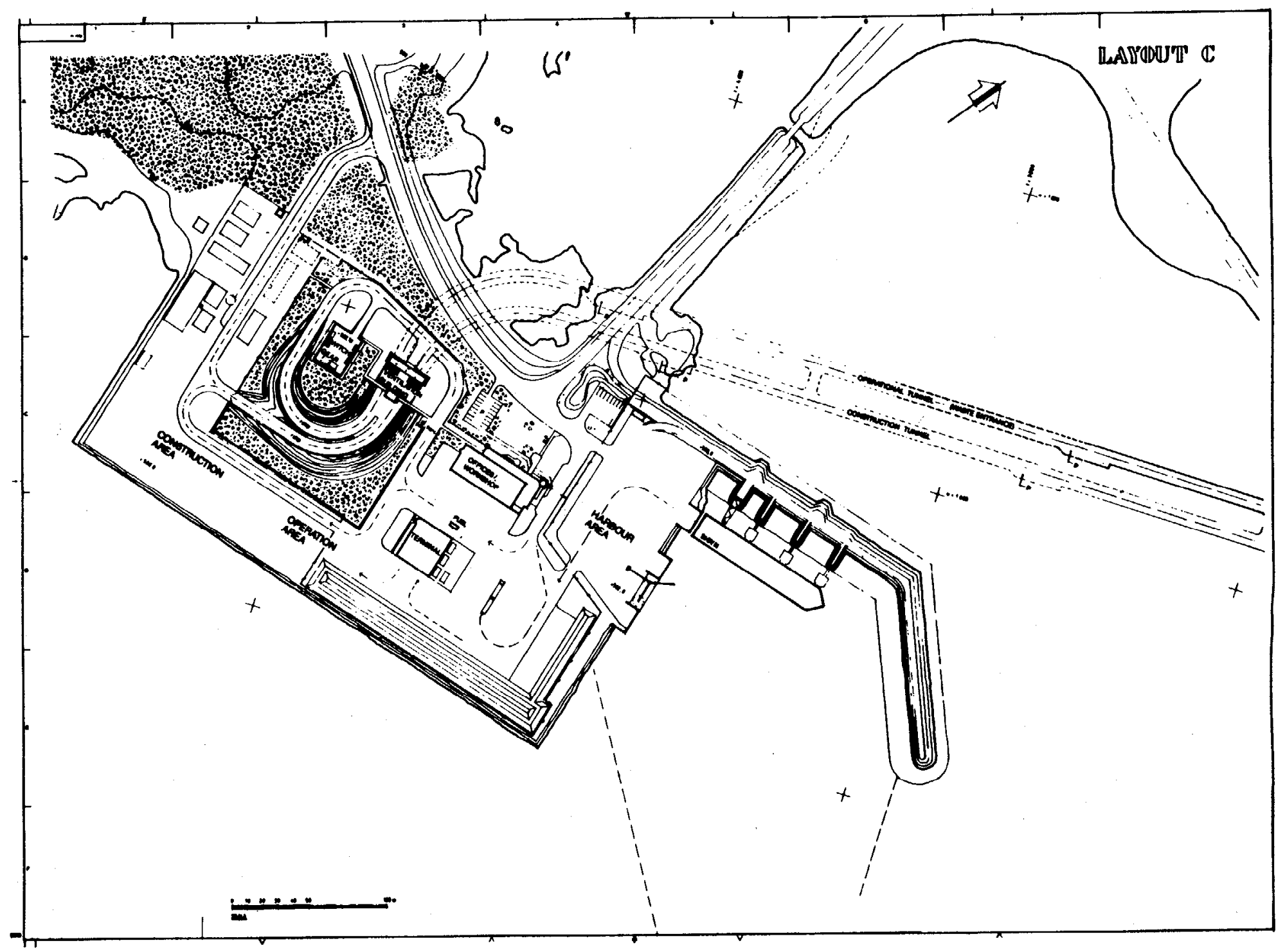

Fig. 3.10. Site layout of surface facilities (Ref. 5). 


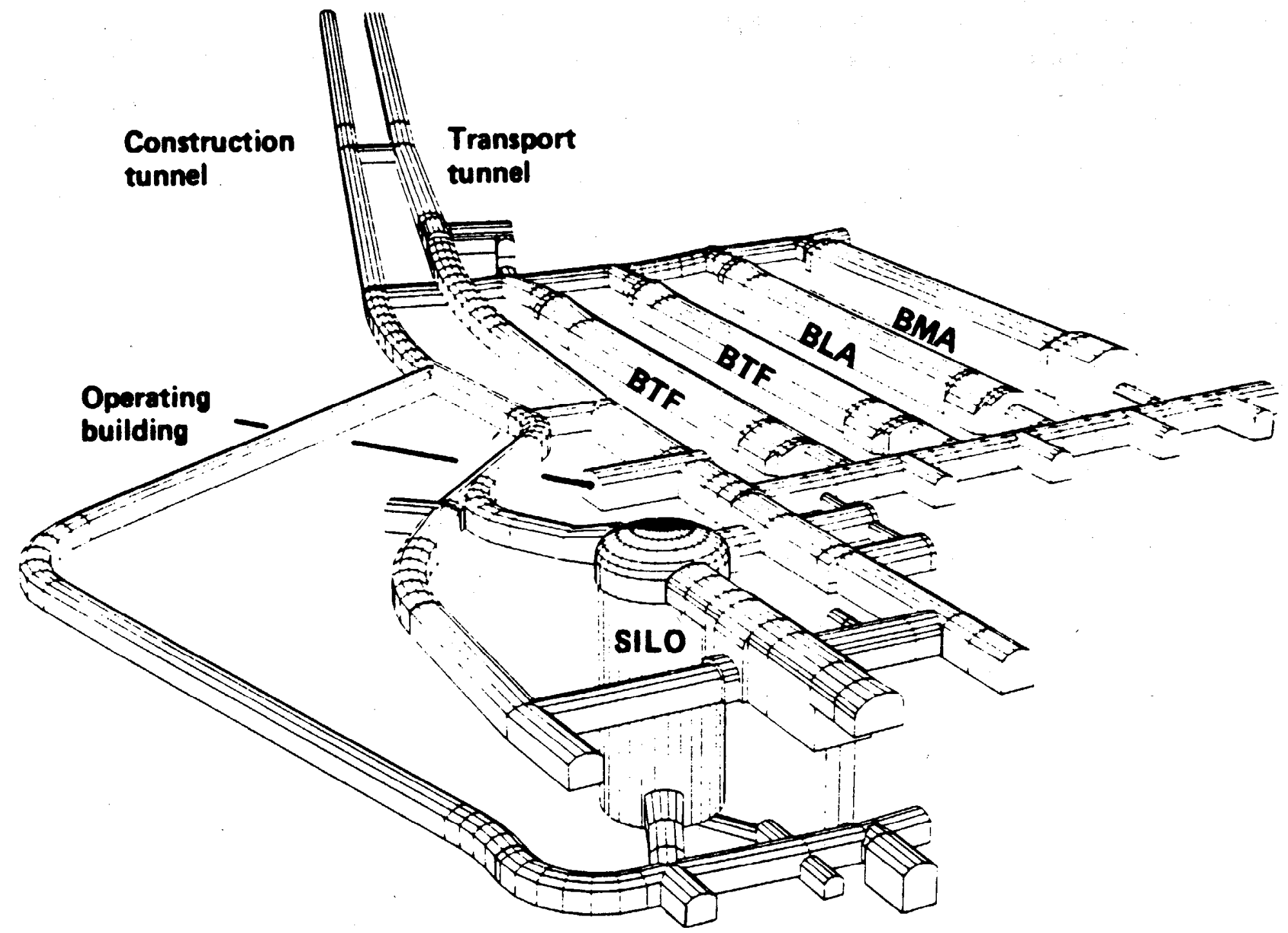

Fig. 3.11. Tunnels and caverns in construction Phase 1 (Ref. 18). 


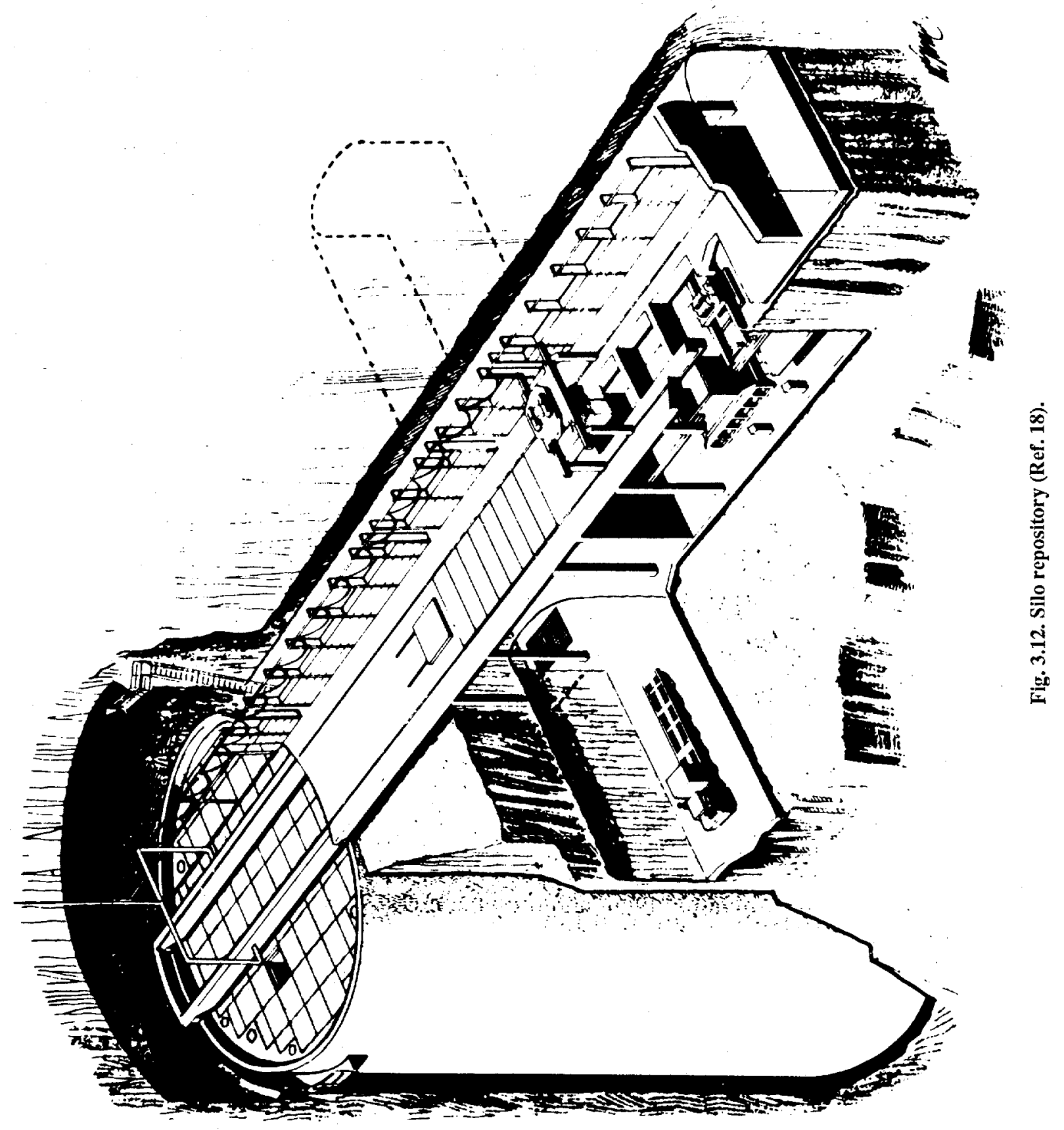


emplacement sequence, and the time required to unload a container with 12 moulds is expected to be about two hours. After the packages have been emplaced in the repository, they are grouted with low-viscosity concrete using the same waste handling equipment.

\subsubsection{Rock caverns}

The rock caverns shown in Fig. 3.11 are labeled according to their intended use as BMA (for deposition of medium-level waste), BLA (for low-level waste), and BTF (for concrete tanks). The BMA (Fig. 3.13) is designed for concrete moulds and metal drums containing resins solidified in cement or bitumen and having surface dose rates less than $30 \mathrm{mSv} / \mathrm{h}$. The overall dimensions of this cavern are $160 \mathrm{~m}$ long by $19.5 \mathrm{~m}$ wide by $16.5 \mathrm{~m}$ high. The storage chamber is divided by concrete partitions into 15 sections, and the waste is emplaced with equipment that is similar to that used in the silo repository. The waste can be grouted in concrete from the space between the rock and the concrete wall.

The BLA is designed for low-level waste, and its overall dimensions are $160 \mathrm{~m}$ in length, $15 \mathrm{~m}$ in width, and $12.5 \mathrm{~m}$ in height. This type of waste is normally packaged in steel drums and boxes and loaded in standard 10 or 20 - $\mathrm{ft}$ freight containers. The containers are limited in weight to $20 \mathrm{t}$, are handled at the SFR with an ordinary forklift truck, and are typically deposited together with the waste. After a chamber has been filled, its entrance will be sealed with concrete plugs.

The BTF caverns are designed for the disposal of big concrete tanks containing dewatered resins and filter material. Their overall dimensions are $160 \mathrm{~m}$ long by $14.8 \mathrm{~m}$ wide by $9.5 \mathrm{~m}$ high. One side of the transport container used for concrete tanks has doors which allow the tanks to be unloaded with a radiation-shielded forklift truck. The forklift then deposits the tanks in two layers in the BTF caverns where they will subsequently be grouted, probably during final decomissioning of the repository.

\subsection{REFERENCES FOR SECTION 3}

1. Swedish Nuclear Fuel and Waste Management Company, SKB Annual Report 1986, TR 86-31 (May 1987).

2. Swedish Nuclear Fuel and Waste Management Company, SKB Annual Report 1985, TR-85-20 (May 1986).

3. Swedish Nuclear Fuel and Waste Management Company, SKB Activities, brochure dated 1985.

4. "Disposing of Spent Fuel Underground," Nuclear Engineering International, p. 31 (December 1985).

5. Swedish Nuclear Fuel and Waste Management Company, Plan 86 Costs for Management of the Radioactive Waste from Nuclear Power Production, TR-86-12 (June 1986).

6. B. Gustafsson and A. Ekendahl, "Operation of the Swedish Sea Transportation System for Spent Fuel," pp. 533-539 in Vol. 1 of Packaging and Transport of Radioactive Materials (PATRAM 86), Davos, 16-20 June, 1986, IAEA, Vienna, 1987.

7. B. Gustafsson and B. Lenail, "The Realization of a Sea Transport System for Radioactive Material," pp. 1382-1390 in PATRAM '83, Seventh Int. Symp. on Packaging and Transportation of Radioactive Materials, New Orleans, May 15-20, 1983, CONF-830528. 


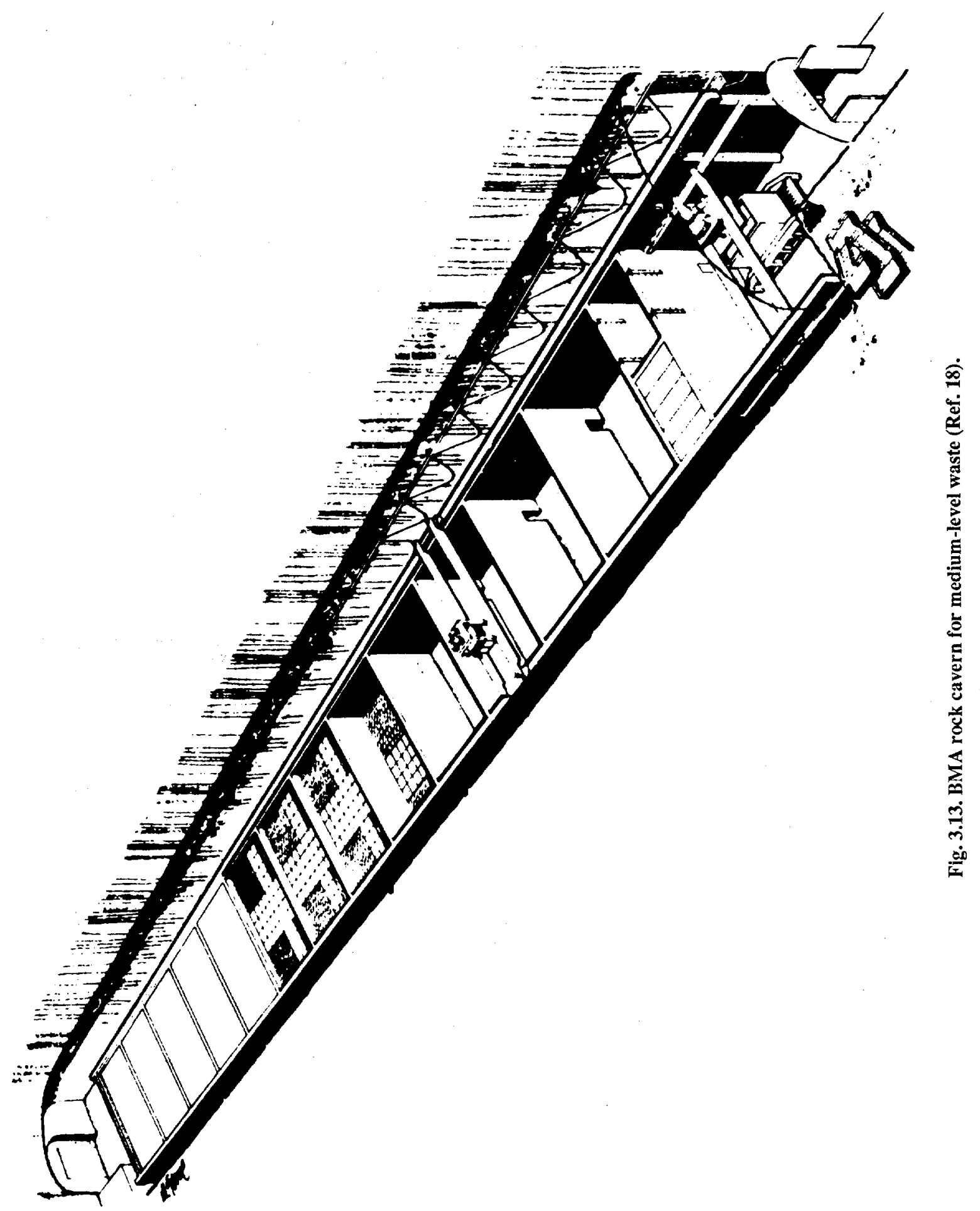


8. B. Gustafsson, "The Swedish Transport System for Radioactive Material," Nuclear Europe, 5/1984, p. 22.

9. Swedish Nuclear Fuel and Waste Management Company, M/S Sigyn, brochure dated April 1986.

10. "Sigyn, a Roro/Lolo Ship for Spent Nuclear Fuel," The Motor Ship, December 1982.

11. H. S. Carlsson, SKB, personal communication of August 19, 1987 to J. O. Blomeke, ORNL.

12. B. Gustafsson, "The Swedish Approach to Spent Fuel Management as Regards Intermediate Storage and Reprocessing," pp. 111-131 in Spent Fuel Storage Alternatives, Proceedings of an IAEA Advisory Group/Specialists Meeting, Las Vegas, November 17-21, 1980, DOE-SR-0009.

13. B. Gustafsson, O. Jansson, and G. Chevrier, "The Realization of the Central Interim Storage Facility for Spent Nuclear Fuel," paper presented at the European Nuclear Conference, ENC '86, June 1-6, 1986, Geneva.

14. B. Brundin and J. Vogt, "Experience from Operation of the Swedish Central Intermediate Storage Facility," pp. 11-24 in Long Term Wet Spent Nuclear Fuel Storage, Proceedings of a Technical Committee Meeting on Behavior of Used Fuel Assemblies and Storage Equipment at Long Term Wet Storage Conditions, Leningrad, 26-30 May, 1986, IAEA-TECDOC-418 (1987).

15. Swedish Nuclear Fuel and Waste Management Company, Central Interim Storage Facility for Spent Nuclear Fuel_CLAB, brochure dated 1986.

16. Swedish Nuclear Fuel and Waste Management Company, CLAB Central Storage Facility for Spent Fuel, Handling, Transportation, Safety, brochure dated 1982.

17. "Disposing of a Problem in Sweden," Engineering News Record, p. 29 (October 30, 1986).

18. T. Hedman and I. Aronsson, "The Swedish Final Repository for Reactor Waste (SFR)," paper presented at the International Symposium on the Siting, Design, and Construction of Underground Repositories for Radioactive Wastes, March 3-7, 1986, Hanover, IAEA-SM-289/16.

19. S. Pettersson and B. Gustafsson, "Large Shiclded Containers for Transport of Reactor Wastes to Their Final Repository in Sweden," pp. 111-121 in Vol. 2 of Packaging and Transportation of Radioactive Materials (PATRAM '86), Davos, 16-20 June, 1986, IAEA, Vienna, 1987.

20. Swedish Nuclear Fuel and Waste Management Company, Final Repository for Reactor Waste-SFR, undated brochure.

21. S. Pettersson and T. Hedman, "Managing Power Station Wastes," Nucl. Eng. Int., p. 38 (December 1985). 


\section{SPENT FUEL HANDLING IN THE FEDERAL REPUBLIC OF GERMANY*}

This section focuses on the handling of LWR spent fuel in the Federal Republic of Germany (FRG). Although all of the spent fuel in the FRG is presently held in fuel storage pools at the nuclear power stations, the 1500 -tU Gorleben interim storage facility is technically ready for operation, and the major components (especially the casks) have been shown in demonstrations and some limited operations to meet, or exceed, all of the required design and performance criteria.

Following a discussion of the background of the present spent fuel storage situation, the functional requirements and design criteria of the interim storage facilities, the equipment, and the transport/storage casks are presented. Finally, the operational aspects of these interim storage systems and the major investigations and demonstrations that have been performed in the course of their development are summarized.

\subsection{BACKGROUND OF LWR SPENT FUEL STORAGE}

\subsubsection{Legal Requirements}

According to the Federal Atomic Energy Act (AtG) of 1959, amended in 1976, all participants in the nuclear fuel cycle shall (1) recover and recycle safely the resources contained in the spent fuel or (2) classify the spent fuel as waste and dispose of it safely if reprocessing is neither technically feasible nor economically justified.

The AtG also defines the respective responsibilities of the Federal Government and industry. ("Industry" means those utilities which own and operate nuclear power plants.) The Government is responsible for the final geological disposal of the nuclear wastes, and this task has been delegated to the Physikalisch Technische Bundesanstalt (PTB), or Physical Technical Office. The industry is responsible for the development, construction, and operation of all other backend facilities, including transport, interim storage, reprocessing, and waste conditioning. The utilities must also show that they can provide "Entsorgung" (waste management) of spent fuel at least six years before it is discharged from the reactor. This can be shown by providing adequate storage capacity for the expected amount of discharged fuel in the reactor storage ponds and/or by negotiating reprocessing contracts (presently with COGEMA or BNFL).

In 1974 the Federal Government proposed the creation of an "Integriertes Entsorgungszentrum" (integrated waste management center) where all the facilities associated with the backend of the fuel cycle would be concentrated (spent fuel storage, reprocessing, recycle uranium and plutonium fuel fabrication, and waste conditioning and disposal). The site selected for this purpose was at Gorleben, a village in the community of Gartow in the

*This section was taken from the report, Survey of Spent Fuel Handling in the Federal Republic of Germany, NIS Report No. 890 (August 1987) prepared by D. Eder and A. Wolf, NIS Ingenieurgesellschaft GmbH, Hanau, FRG for Martin Marietta Energy Systems, Inc., Oak Ridge National Laboratory, Oak Ridge, Tennessee 37831 through NUS Corporation, 910 Clopper Road, Gaithersburg, Maryland, under Contract No. 11XSA491V. 
Luchew-Dannenberg county of Lower Saxony. The Deutsche Gessellschaft fur Wiederaufarbeitung von Kernbrennstoffen $\mathrm{mbH}$ (DWK), or German Company for Reprocessing of Spent Nuclear Fuel Ltd., was given the responsibility for the Entsorgungszentrum. After a safety analysis report was prepared and submitted to the state authority, an extensive public hearing and evaluation was conducted. The outcome was that while this integrated waste management center was seen to be technically feasible, it was nevertheless judged to be politically infeasible.

In 1979 the integrated center concept was formally abandoned, and the Federal Government, in agreement with the state governments, has subsequently developed what is known as the "Entsorgungskonzept" (waste management concept). This concept comprises the following:

- interim storage of spent fuel, either at the nuclear power plants or at centralized away-from-reactor sites;

- reprocessing of the fuel in an industrial facility which has yet to be built;

- recycle of recovered uranium and plutonium in power reactors;

- waste solidification (conditioning); and

- waste disposal in a Federal underground repository.

In addition to this concept, alternative disposal technologies were investigated which were based on the direct disposal of spent fuel without reprocessing. ${ }^{1}$ Consequently, two parallel fuel cycle strategies are being developed at this time: the preferred Entsorgungskonzept, which is based on reprocessing and recycle of uranium and plutonium, and the concept of direct disposal of spent fuel without reprocessing.

In 1985 the Social Democratic Party, a major political party in West Germany, took a position in opposition to reprocessing because of the possible diversion of plutonium for use in nuclear weapons. This party has since announced that they favor eliminating nuclear power altogether in Germany by 1995.

\subsubsection{Present Management of Spent Fuel}

Eighteen LWR units with a total installed capacity of 18,600 MW(e) are presently operating in the FRG. Four more units are scheduled to be in operation by the end of 1989 , and by the year 2000 a total installed nuclear capacity of about $27,000 \mathrm{MW}(\mathrm{e})$ is expected. About $2500 \mathrm{tU}$ as spent fuel has been discharged thus far, and this inventory is presently increasing at a rate of 500 to $600 \mathrm{tU} /$ year. By the year 2010 , the inventory is projected to exceed $8000 \mathrm{tU}^{2}$

Freshly discharged fuel is stored for at least one year in water pools at the nuclear power stations, but it is planned that a total storage time of at least seven years will be provided before reprocessing. All of the new and more recent reactors in the FRG are provided with storage capacities for up to eight years in high-density racks, and many of the older plants have been backfitted with these racks. However, technical constraints prevent some of the older PWRs and most of the BWRs from being backfitted in this way. Fuel storage capacities at the Wurgassen and Stade nuclear plants are being increased by constructing additional external facilities at these sites. A listing of the internal water pool storage capacity that is presently available at each West German power reactor and the date to which provision for waste management has been proven (Entsorgungsnachweis) is given in Table $4.1 .^{3}$ 
Table 4.1. Available free water pool storage capacities at FRG nuclear power plants and expected dates when filled ${ }^{3}$

\begin{tabular}{lcc}
\hline \multicolumn{1}{c}{$\begin{array}{c}\text { Nuclear } \\
\text { power } \\
\text { plant }\end{array}$} & $\begin{array}{c}\text { Available free } \\
\text { storage capacity } \\
\text { (tU) }\end{array}$ & $\begin{array}{c}\text { Year to which proven } \\
\text { management has } \\
\text { been provided }\end{array}$ \\
\hline Biblis A & 24.1 & 1993 \\
Biblis B & 35.8 & 1994 \\
Obrigheim & 9.06 & 1992 \\
Philippsburg 1 & 1.54 & 1993 \\
GKN 1 & 0.36 & 1994 \\
Stade & 4.28 & 1992 \\
Unterweser & 169.0 & 2004 \\
Grohnde & 309.0 & 1998 \\
Isar 1 & 208.0 & 1994 \\
Grafenrheinfeld & 197.0 & 1994 \\
Gundremmingen B & 433.0 & 2001 \\
Gundremmingen C & 433.0 & 2000 \\
Wurgassen & 20.1 & 1992 \\
Krummel & 136.0 & 1996 \\
Brunsbuttel & 19.9 & 1995 \\
Philippsburg 2 & 309.0 & 2000 \\
Mulheim-Karlich & 267.0 & 1995 \\
Brockdorf & 312.0 & 1999 \\
\hline aIn excess of one full core reserve capacity. & \\
b"Proven" management may be provided by the existing free storage \\
capability or by contracts with COGEMA or BNFL for reprocessing.
\end{tabular}

The world's first interim storage facility for LWR spent fuel using dry transport/storage casks was built at Gorleben. The storage hall at Gorleben has a capacity of $1500 \mathrm{tU}$, which corresponds to 420 casks, and construction of a second facility of the same design was started in 1983 at Ahaus in Northrhine-Westphalia. ${ }^{4}$ Legal actions have prevented any recent progress being made with either of these facilities, however. In the case of Gorleben, a law suit was filed in 1984 that has blocked the start of spent fuel storage operations therc. At Ahaus, an operating license has been issued but a court order in late 1986 has prevented completion of construction. Construction was started in 1987 on still a third facility of the same design and size to serve as part of the Wiederaufarbeitungsanlage Wackersdorf (WAW), or the Wackersdorf Reprocessing Plant in Bavaria. 
With regard to reprocessing, the pilot plant, Wiederaufarbeitungsanlage Karlsruhe (WAK) has reprocessed about $170 \mathrm{tU}$. The main purpose of this small plant is for research and development on reprocessing of mixed oxide fuel, high burnup fuel, and fuel with recycle uranium. A secondary objective is to gain plant operating experience and to provide a technical basis for the planning and design of the WAW, the FRG's first industrial reprocessing plant.

In the near tcrm, reprocessing of West German spent fuel will be done at La Hague and Sellafield. The FRG utilities have signed reprocessing contracts for $3160 \mathrm{tU}$ with COGEMA and for $760 \mathrm{tU}$ with BNFL. In the meanwhile, site preparation for the WAW began in late 1985 under the leadership of Kraftwerk Union AG (KWU), construction of the main process building is expected to start in 1988, and plant startup is scheduled for 1995. The reprocessing capacity of the WAW will be about $350 \mathrm{tU} / \mathrm{year}$ initially and may be increased eventually to $500 \mathrm{tU} / \mathrm{year}$.

As mentioned in Sect. 4.1.1, the FRG is also developing an alternate fuel cycle strategy that is based on the direct disposal of spent fuel. ${ }^{1}$ This program is being conducted by Kernforschungszentrum Karlsruhe (KfK), or Karlsruhe Research Centre, and some associated companies. It is focused on fuels for which reprocessing is not technically feasible or economically justifiable but has obvious broader applications to LWR spent fuel as well. The reference concept of Project Andere Entsorgungstechniken (PAE), or Project for Altemative Disposal Techniques, is based on the emplacement of large, heavily shielded storage casks in tunnels of salt mine repository. As part of this concept, the Pollux spent fuel cask concept has been developed. 5 The Pollux is a containment system for transport, long-term interim storage, and disposal of spent fuel and is based on the use of a double shell (cask and shielding overpack) package that will serve all three purposes. Also, it is expected to be suitable for either horizontal emplacement in repository tunnels or for vertical emplacement in boreholes. A 35-tU/year pilot plant for conditioning the fuel based on the Pollux concept is planned by DWK for construction at the Gorleben site in $1989 .^{\circ}$

\subsection{STORAGE FACILITIES AND MAJOR COMPONENTS}

\subsubsection{Interim Storage Facilities}

Since the designs of the three planned interim storage facilities (Gorleben, Ahaus, and Wackersdorf) are basically the same, the major features of only the existing Gorleben facility will be described here, as taken from more detailed information given in Refs. 7, 8, and 9.

The Gorleben interim storage site has an area of about 11 ha (27.18 acres) and is located about $2 \mathrm{~km}$ south of the village of Gorleben. The following buildings are located on the site (Fig. 4.1):

- spent fuel storage building

- storage building for low-level radioactive waste

- workshop building with mechanical and electrical workshop and a storage room for maintenance and repair of the plant

- operations building with rooms for vehicle parking, equipment storage, fossil fuel storage, transformers, etc.

- administration building with offices, first aid station, sanitary facilities, and canteen 


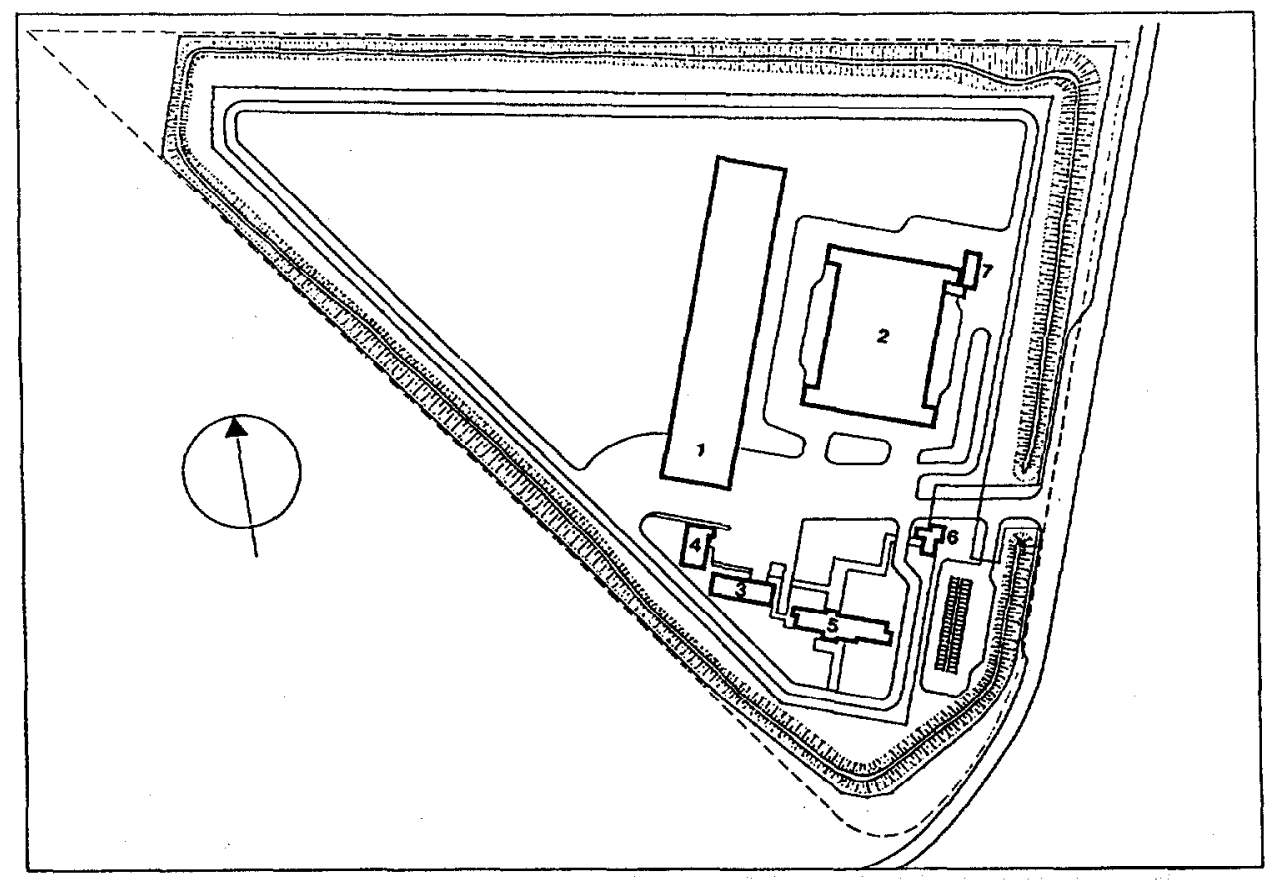

1. Storage hall for spent fuel assemblies in cask

2. Storage hall for low-level radioactive waste materials in drums

3. Workshop building

4. Operation building

5. Administration building

6. Doorkeepers building

7. Low-level radioactive waste materials reception building

Fig. 4.1. Site plan of the Gorleben interim storage facility.

- guardgate building for access and exit control of personnel, materials, etc.

- low-level waste receiving building

A perspective view of the site is given in Fig. 4.2.8 The site is enclosed by two fences. There is an earthen dam between the fences that offers additional protection against direct radiation. (The original political purpose of this dam was to "hide" the plant, or to avoid the sight of a large industrial facility in that area.) Earthen dams are not needed or planned at Ahaus and Wackersdorf. The access road is on the east side of the site and no rail connection is available.

The storage building is a conventional hall construction having dimensions $189 \mathrm{~m}$ long, 38 $\mathrm{m}$ wide, and $20 \mathrm{~m}$ high (see Fig. 4.3) ${ }^{8}$ The hall is divided by an 8 -m-high shielding wall into a cask reception area and a storage area. A bridge crane can travel over the entire length of the building to provide cask transport to every storage position.

The storage area is a permanent radiation protection control zone, while the reception area is a temporary radiation protection zone. The entrance and exit for the transport trucks are provided by two roll-gates in the reception area. There are also the normal personnel entry and the required escape gates in the building. 


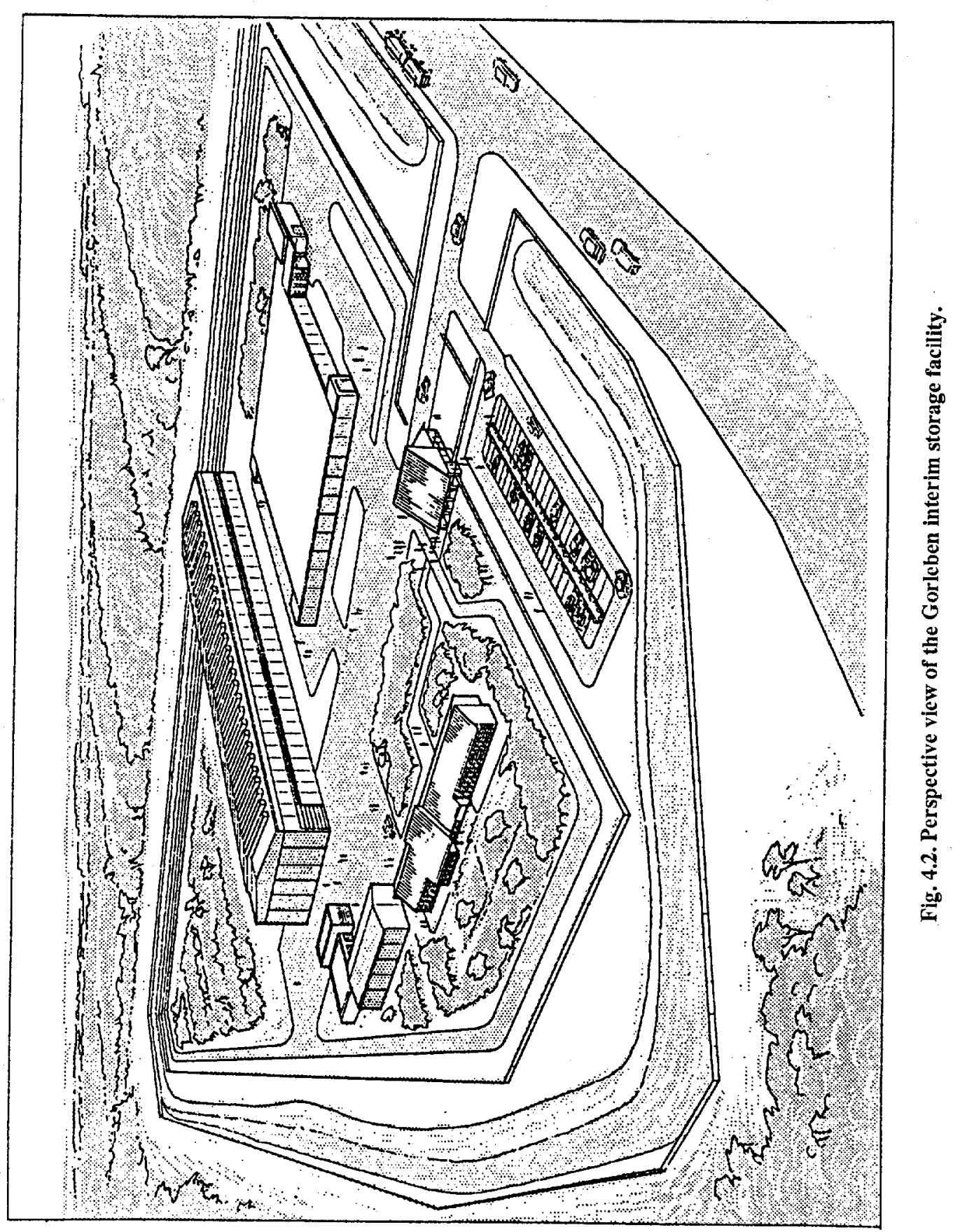



The cask reception area is arranged to allow for smooth cask handling with minimum radiation exposure of the personnel. The following facilities are located in two levels:

- truck entrance/exit and unloading/loading area

- personnel entry on the lower floor with dosimeter distribution, clothing change room, toilets, electronics room with control boards, etc.

- operations room

- cask repair and inspection bay

- waste container area

- storage room for lifting beams, shock absorbers, cover hoods, etc.

- air conditioning, ventilation room, laboratory, etc., on the upper floor

The cask storage area comprises the main part of the building. The base plate consists of reinforced concrete plate sections with expansion joints. The side walls and the room construction are also made of reinforced concrete. The storage building also provides additional radiation shielding to the environment. In the sidewalls and the roof there are ventilation openings to allow natural convection of the air and to provide passive heat removal.

Heat removal from the facility is based on the following design assumptions:

- storage capacity of $1500 \mathrm{tU}$ as spent fuel assemblies

- storage casks CASTOR Ia, Ib, Ic, and IIa (the TN transport/storage cask family was not available at the time of the design)

- continuous fill-up of the storage capacity over a 3-year period

- minimum decay time of 1 to 1.5 years, depending on cask type

- 60\% PWR fuel (35 GWd/tU bumup), 40\% BWR fuel (33 GWd/tU burnup)

With these assumptions the maximum residual thermal power was calculated to about $9 \mathrm{MW}$.

Results of analyses and experiments have shown that the residual heat can be removed with an average temperature increase in the coolant of $16^{\circ} \mathrm{K}$ and a mass flow of about $500 \mathrm{~kg} / \mathrm{s}$. The surface temperature of casks is 60 to $80^{\circ} \mathrm{C}$ depending on heat generation (decay time) and storage position. Only in the worst cases can temperatures of 100 to $120^{\circ} \mathrm{C}$ be expected.

Concerning radiation protection, it is a characteristic of this concept that all radioactive substances are enclosed safely in the transport/storage casks, except for some potential minor contamination on the cask surfaces, and only a small fraction of the gamma and neutron radiation can penetrate the cask walls. According to the transport regulations, the dose rate at the outer surface of the cask is limited to $2 \mathrm{mSv} / \mathrm{h}(200 \mathrm{mrem} / \mathrm{h})$. Actual dose rates have been shown to be far below this limit. The DWK design dose limit is $0.1 \mathrm{mSv} / \mathrm{h}(10 \mathrm{mrem} / \mathrm{h})$ for gamma and neutron radiation each.

For shielding design calculations, the dose limit of $200 \mathrm{mrem} / \mathrm{h}$ at the cask surface was assumed. The walls and the room were dimensioned so that the calculated environmental dose by direct radiation and skyshine was only about $0.01 \mathrm{mSv} / \mathrm{h}(1 \mathrm{mrem} / \mathrm{h})$. In the cask reception area, the dose rate from the storage area is limited to values lower than $0.005 \mathrm{mSv} / \mathrm{h}(0.5 \mathrm{mrem} / \mathrm{h})$, which is achieved by the concrete shielding wall hetween the storage and reception areas. In special cases, mobile shielding walls can be added as needed. 
Only very small quantities of contaminated waste water should result from cask reception and maintenance requirements. This water will be collected and transported off-site to a low-level waste processing facility. Solid waste will also be generated in very small amounts from wipe tests, etc. These latter wastes will be collected and transported off-site in drums.

The average water consumption of the plant is stated to be about $1 \mathrm{~m}^{3} / \mathrm{h}$, and it is obtained from the normal water supply grid. Nonradioactive waste water is discharged into the public canal.

The exhaust air will not be contaminated under normal conditions because of the leak-tight casks; the low neutron flux at the surface ensures that no radioactivation of dust will occur. Therefore, no routine air monitoring is required. A mobile aerosol and gas control instrument is available for control purposes, however, and the local dose is constantly measured at several selected positions in the storage area.

Electric power is furnished by a $10-\mathrm{kV}$ cable from the regional grid. For internal distribution, the voltage is reduced to $380 \mathrm{~V}$. There are no safety-related components which need electric power. In case of failure of the power grid, an auxiliary supply can serve for lighting the buildings and the fence and as a supply for low-voltage equipment.

Figure 4.4 is an aerial view of the Gorleben site. Photographs of a CASTOR cask in the repair and inspection bay and in the storage hall are presented in Figs. 4.5 and 4.6, respectively.

\subsubsection{Transport/Storage Casks}

\subsubsection{General}

The basic element of the FRG dry storage facilities for spent fuel is the cask that serves for both transport and storage. One important item in the cask development phase was to bring the fabrication cost down to a level that would allow the cask storage concept to be seriously considered for implementation. A key idea in this regard was the use of nodular cast iron for the cask body as a single, large piece of material.

Development of such a storage cask was initiated in 1979 by DWK and STEAG, with Gesellschaft fur Nuklear Service mbH (GNS) or Company for Nuclear Service Ltd. A type B (U) license certificate for the CASTOR cask was obtained in 1980. In addition to fulfilling type B (U) Transport Regulation Requirements, several extreme load tests have been performed to show that these casks can withstand, for example, an aircraft crash without loss of safety functions. Further design features are related to the long-term storage capability and consist of a double lid system with interspace monitoring and sufficient heat removal capability to keep the fuel cladding temperatures below the degradation limit. The safety analysis reports for the Gorleben and Ahaus dry storage facilities were based on the use of CASTOR casks.

As an additional supplier of dry transport/storage casks, Transnuklear GmbH (TN) first presented its TN-1300 cask in November 1980 at the PATRAM conference..$^{10}$ Since that time, an entire family of TN dry transport/storage casks has been developed. Type B (U) licenses have been obtained for these casks, and several safety and handling tests have been performed.

\subsubsection{Characteristics of the CASTOR and TN spent fuel transport/storage casks ${ }^{11-14}$}

Characteristics of the casks that are presently acceptable for storage of LWR spent fuel at Gorleben is given in Table 4.2 .

The bodies of CASTOR casks consist of one piece of modular cast iron. The casting is performed by Siempelkamp (Fig. 4.7). The wall thickness of the cask bodies range up to $440 \mathrm{~mm}$, 


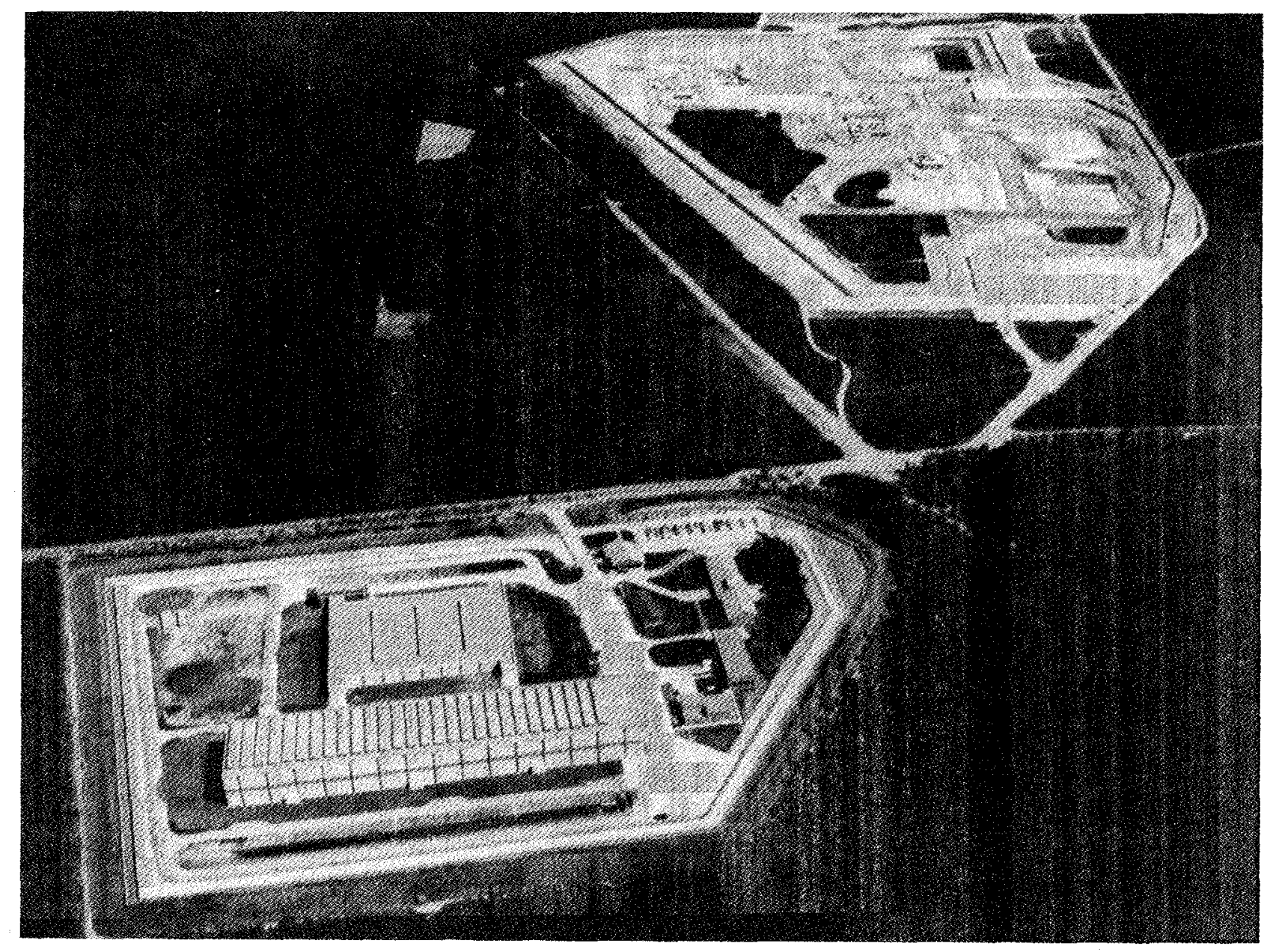

Fig. 4.4. Aerial view of the Gorleben Interim storage facillty (Registered by Ref. Pras. Munster, Nr. 2555/84). The storage hall for spent fuel assemblies in casks is in the foreground; behind it is the storage hall for low-level waste. In the background, the drilling site to explore the salt dome for final storage can be seen. 


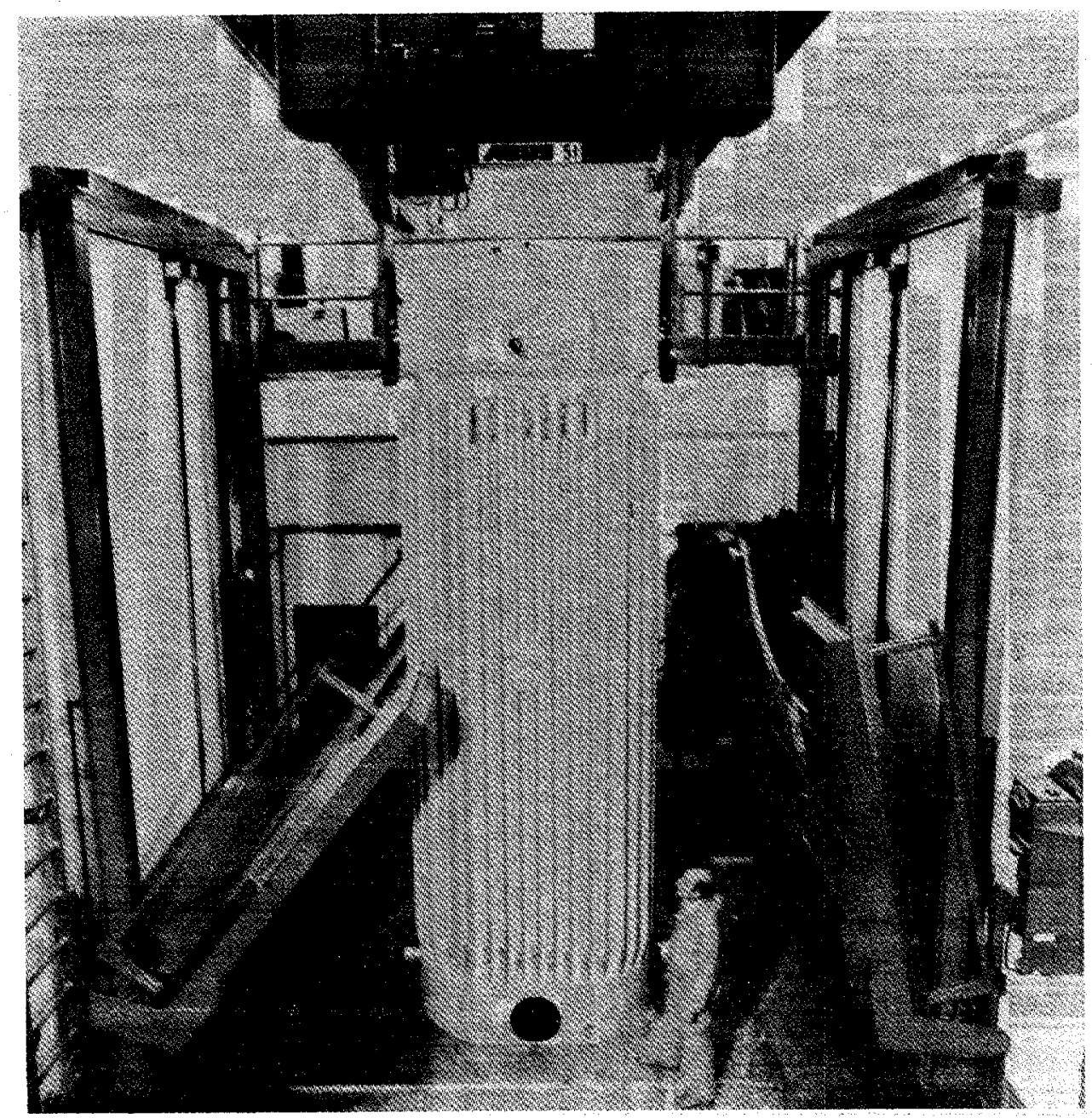

Fig. 4.5. CASTOR cask (without spent fuel) in the repair and inspection bay (At the right and left sides are the elevating platforms).

and the ovcrall dimensions of the CASTOR Ia, Ib, Ic, and IIa (which were considered in the safety analysis report of the Gorleben facility) range from 4.8 to $6.0 \mathrm{~m}$ in length and 1.6 to $2.0 \mathrm{~m}$ in width. The weight ranges from 60 to $120 \mathrm{t}$, and the capacities vary from 4 to 9 PWR assemblies (CASTOR Ia, Ib, and IIa), or 16 BWR assemblies (CASTOR Ic).

The body of the CASTOR cask contains axial borings for the neutron shielding material. Samples of this boring material serve as a control of the quality of the cast iron in the wall. The inner surface of the cask body is protected against corrosion by a layer of galvanic nickel. The fuel assembly basket is of a welded, borated, stainless-steel construction, which holds the fuel assemblies in a safe and exact position. The casks are closed by two stainless-steel cover lids which contain all the connections and penctrations necded for flushing the cavity and for leakage control. Four lifting trunnions, fabricated of forged steel, are inserted into the cask body. 


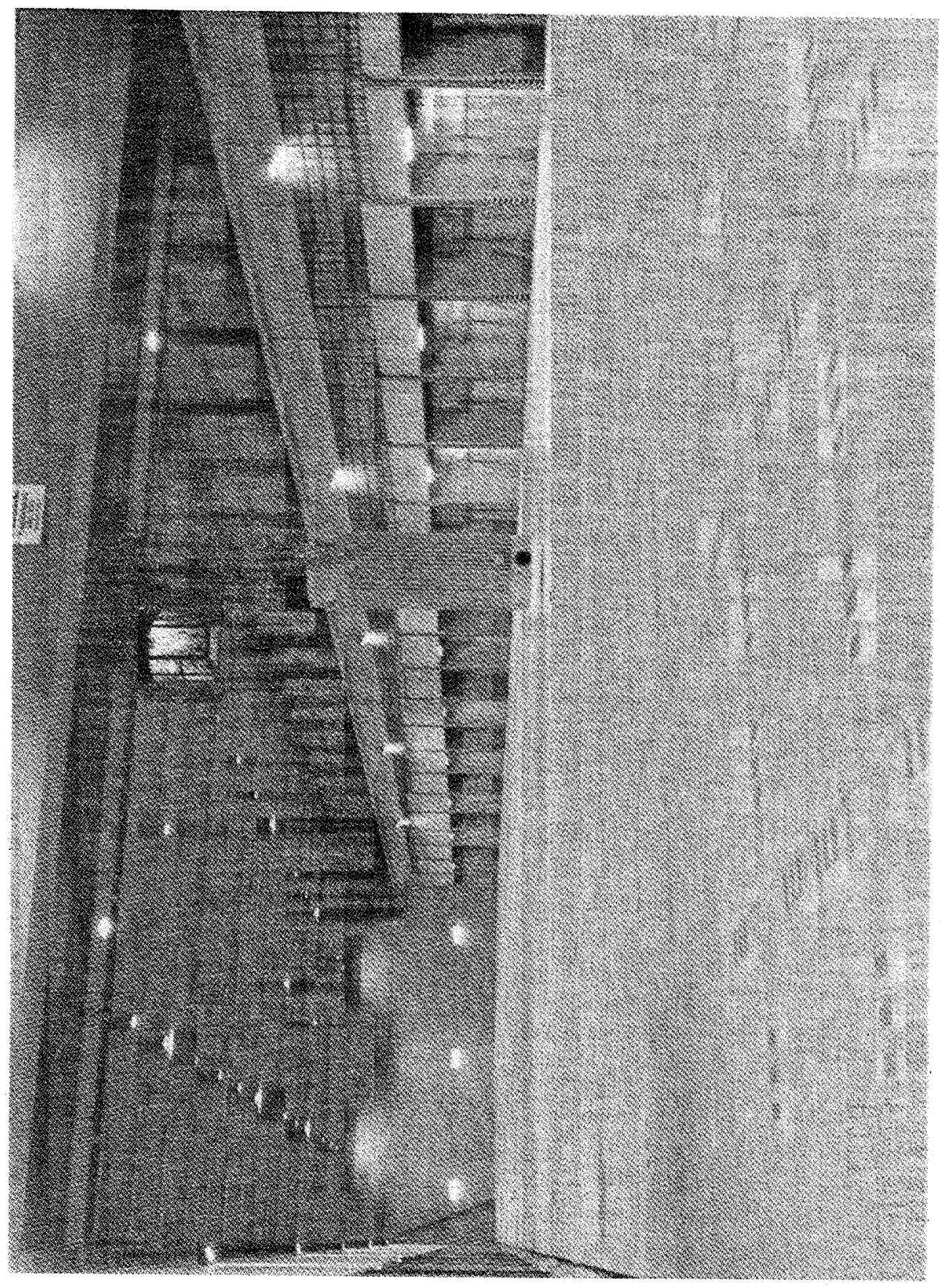


Table 4.2. Characteristics of casks acceptable for storage at the Gorleben Interim Storage Facility?

\begin{tabular}{|c|c|c|c|c|c|c|}
\hline \multirow[b]{2}{*}{ Cask type } & \multirow[b]{2}{*}{$\begin{array}{l}\text { Type of } \\
\text { LWR }\end{array}$} & \multicolumn{2}{|c|}{ Fuel capacity } & \multicolumn{3}{|c|}{$\begin{array}{c}\text { Appropriate } \\
\text { cask dimensions }\end{array}$} \\
\hline & & $\begin{array}{l}\text { Weight } \\
\text { (tU) }\end{array}$ & $\begin{array}{l}\text { Number of } \\
\text { assemblies }\end{array}$ & $\begin{array}{l}\text { Weight } \\
(t)\end{array}$ & $\begin{array}{l}\text { Width } \\
\text { (m) }\end{array}$ & $\begin{array}{l}\text { Length } \\
\text { (m) }\end{array}$ \\
\hline CASTOR Ia & PWR & 2.1 & 4 & 80 & 1.6 & 6.0 \\
\hline CASTOR Ib & PWR & 1.4 & 4 & 60 & 1.6 & 4.7 \\
\hline CASTOR Ic & BWR & 3.1 & 16 & 80 & 1.7 & 5.5 \\
\hline CASTOR IIa & PWR & 4.9 & 9 & 120 & 2.0 & 6.0 \\
\hline TN-900 & PWR & 3.7 & 7 & 80 & 2.2 & 4.8 \\
\hline TN-900 & BWR & 3.3 & 17 & 80 & 2.0 & 5.4 \\
\hline $\mathrm{TN}-1300$ & PWR & 6.4 & 12 & 120 & 2.4 & 6.0 \\
\hline TN-1300 & BWR & 6.5 & 33 & 115 & 2.4 & 5.7 \\
\hline CASTOR KRB-MOX & BWR & 1.9 & 16 & 64 & 1.6 & 4.8 \\
\hline CASTOR WO-MOX & PWR & 4.4 & 16 & 85 & 2.0 & 4.2 \\
\hline TN VAK-MOX & BWR & 1.0 & 17 & 45 & 1.8 & 2.5 \\
\hline TN 900/2-09 MOX & PWR & 2.7 & 8 & 86 & 2.3 & 4.8 \\
\hline
\end{tabular}




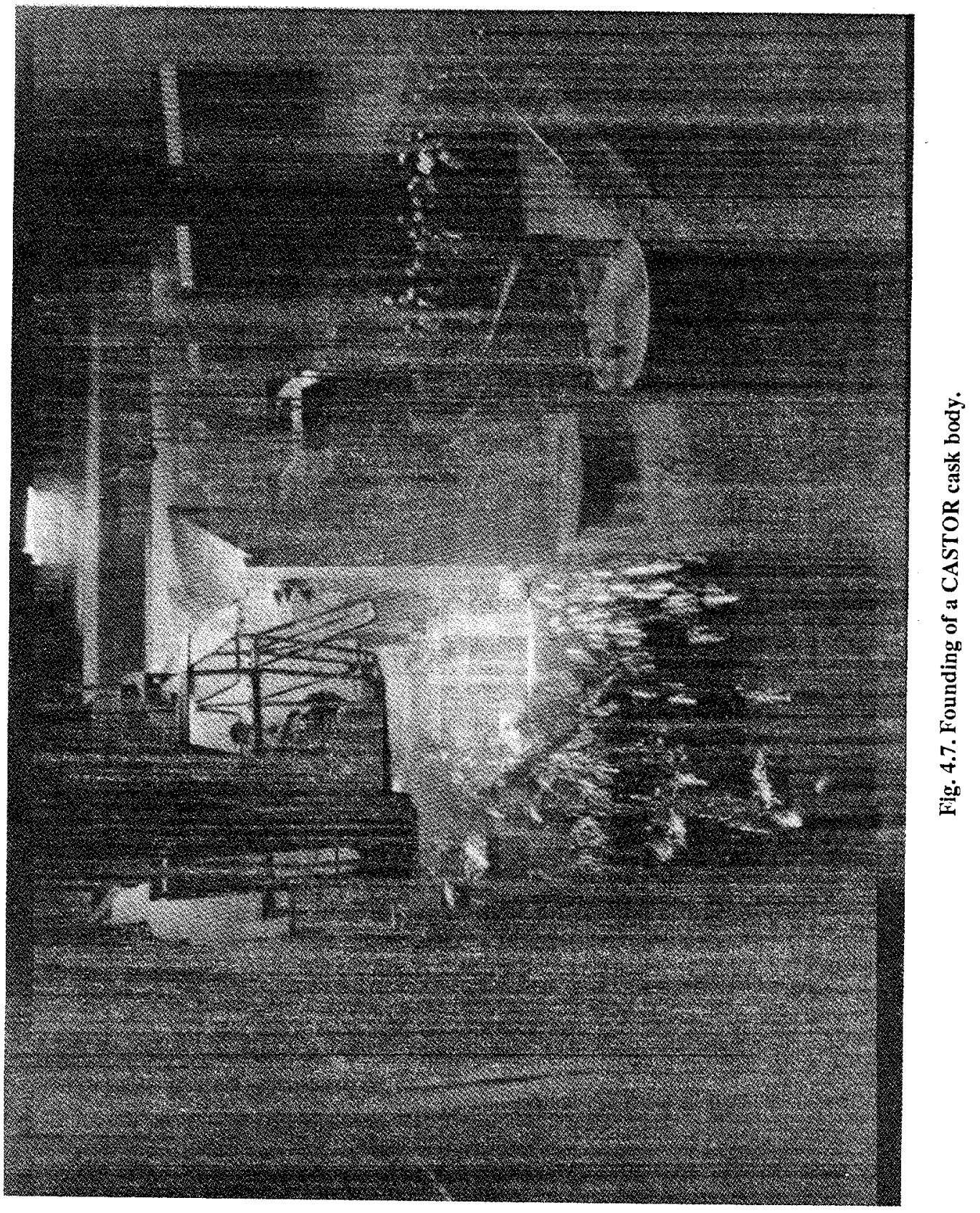


Detailed descriptions of the TN-1300 are given in Refs. 13 and 14. The status of the respective casks is as follows:

- The CASTOR casks Ia, Ib, Ic, and IIa are licensed as transport and storage casks.

- Because there is no operating license in force for interim storage at Gorleben, the only existing storage experience is that which has been derived from the demonstration programs (Sect. 4.6).

- Since CASTOR casks are used routinely for spent fuel transport from German nuclear power plants to the WAK at Karlsruhe, some handling and transport experience does exist.

- The only existing TN-1300 cask is licensed. It has been used for demonstration tests at Biblis and for several transfers of spent fuel within the Biblis complex. It is now stored at TN in Hanau. Six TN-900 casks for BWR assemblies of the Brunsbuttel type are being manufactured at Thyssen for delivery in late 1987.

- The future trend in the FRG will be to build casks with greater capacity. This will be possible because the minimum cooling time can be increased from the original 1 year to about 5 years, and most plants now have adequate on-site storage capacity.

The large-capacity casks will be similar to the CASTOR-V cask for 21 PWR assemblies and to the TN-24 cask for 24 PWR-assemblies as they are tested at Idaho National Engineering Laboratory within the framework of the DOE Nuclear Waste Policy Act activities. Also, five CASTOR-V casks have been licensed and are now in use for fuel storage at the Independent Spent Fuel Storage Installation (ISFSI) at the Virginia Electric Power Company's Surry Power Station.

The GNS plans to develop an even larger capacity cask than CASTOR-V, the CASTOR-X, which will also be made of cast iron. So far, as is known, no effort is under way at TN to develop a cask beyond the TN-24. The TN-24 cask body is made of forged steel as are all other TN casks except the TN-1300 and TN-900.

\subsubsection{Cask sealing system}

An important feature of the storage casks is the long-term sealing system, together with the surveillance and repair concept. This is described below, with reference to Fig. 4.8.11

To assure a multiple barrier seal, the cask cavity is closed by a double-lid system. Each of these lids and the single lids which close the small openings necessary for handling and control purposes are sealed with a metal ring. Special "Helioflex" sealing-rings manufactured by the French company Cefilac are used for this purpose. These rings are composed of an elastic annular spring core made of a nickel based alloy, an inner stainless-steel sheet, and an exterior soft liner of aluminum or silver. The sealing function is accomplished by plastic deformation of the external liner and an elastic response of the spring core. The sealing rings are positioned in the lid grooves, where the groove geometry determines the deformation of the seal, and the lid screw tension assures the sealing geometry even under severe accidental shock loadings. The leaktightness requirements of the LWR storage casks are less than $10^{-7} \mathrm{~atm}-\mathrm{ml} / \mathrm{s}$, as determined by the standard helium leak-rate test. 


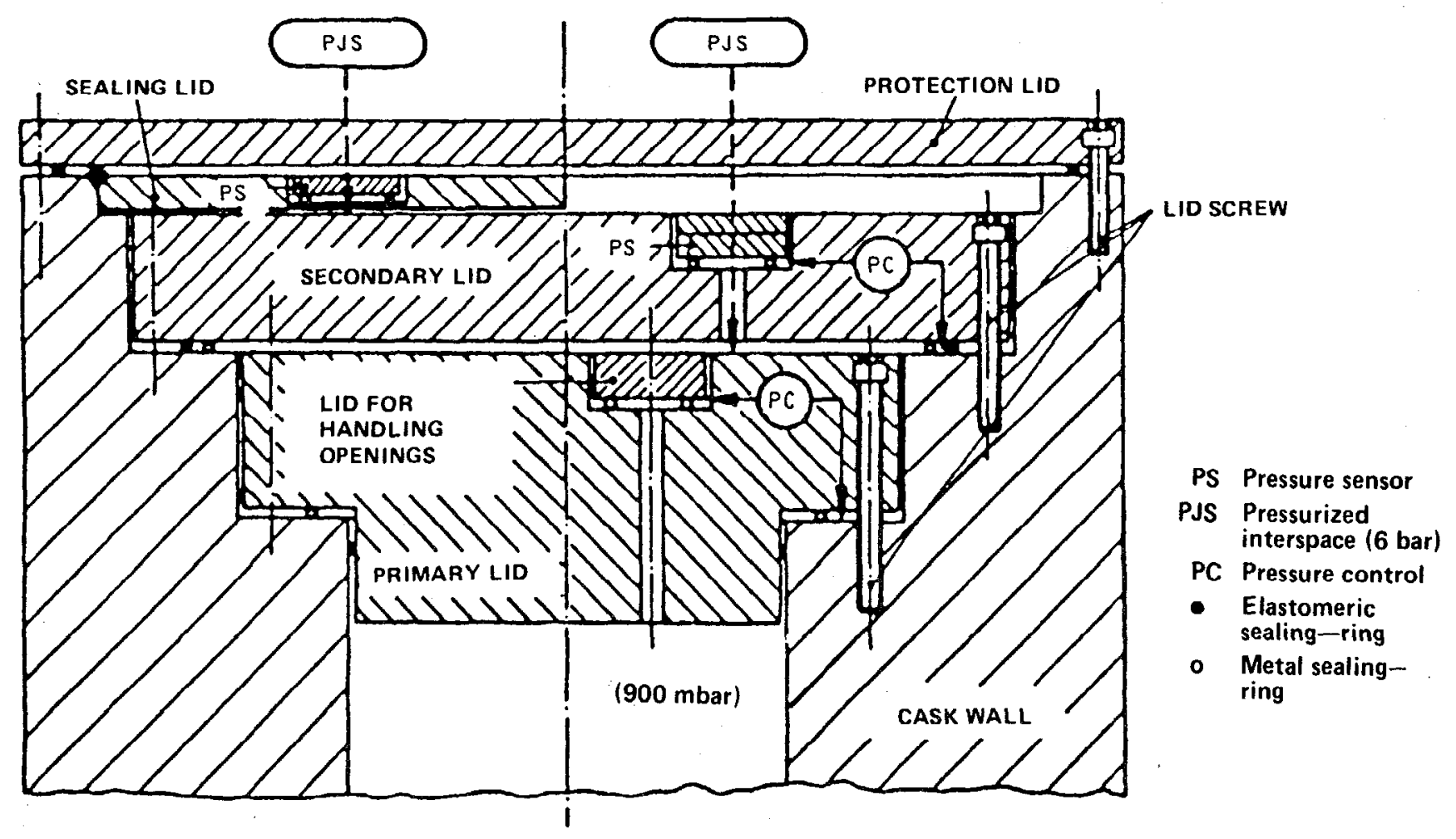

Double Lid System

right hand side: normal lid system

left hand side: repaired lid system

Fig. 4.8. Illustration of a generic transport/storage cask double-lid scaling system. (The normal lid system is depicted at the right of center, and the repaired lid system is shown at the left.) (Ref. 11). 
To minimize corrosive attack by residual moisture from inside, the cask is subjected to a vacuum drying procedure at the power station after loading, which reduces the residual moisture to gram amounts. As an additional measure, an elastomeric sealing-ring is provided on each side of the metal sealing-ring. The impact of increased temperatures, induced potentially by exposure to fire or by covering with debris, has been shown experimentally to have no negative influence on the sealing function.

With respect to long-term phenomena such as stress relaxation or creep fracture of the scaling rings, the licensing evaluation has shown that no systematic sealing failure will occur. (The "Helioflex" sealings have been undergoing long-term tests at Pierrelatte since early 1982.) The FRG licensing experts of the "Bundesanstalt fur Materialprufung, Berlin" (BAM) have evaluated the suitability of the storage casks and the sealing system with positive results. The analytical evaluation of the radioactivity release even under very conservative assumptions has revealed negligible values. ${ }^{11}$

In normal handling, the cask is sealed by the first or primary shielding lid and then by the secondary lid. A third protection lid is applied at the storage facility. The interspace between the lids is pressurized with helium to 6 bar. The pressure of helium in the cask cavity is about 900 mbar. A pressure sensor is inserted in the secondary lid to control and monitor any pressure loss or sealing failure. Every cask will be monitored continuously during storage by this surveillance system. Connections are provided to transmit data from each cask to a central computerized center located in the guard house.

In the event of a pressure loss, the suspect cask can be immediately identified. If the primary lid is shown to be leaktight, the seal in the secondary lid can be replaced. If the primary lid seal has failed, the double barrier system can be reestablished by inserting a sealing lid which is welded or soldered above the secondary lid (shown on the left side of Fig. 4.8).

\subsection{FUNCTIONAL REQUIREMENTS}

The main functional requirements for the spent fuel cask storage systems are:

1. All safety functions are incorporated in the storage casks. The casks are submitted to licensing approval according to type $B(\mathrm{U})$ requirements where it must be proven that the stored fuel cannot achieve criticality under all postulated conditions and that shielding and sealing are maintained even after severe accidents. The cladding temperatures are kept acceptably low by the various cask design features and by the selection and arrangement of fuel assemblies according to their decay characteristics. The storage casks are loaded at subatmospheric pressure and pressurized with inert gas. All openings and connections are sealed by at least two barriers.

2. No specialized safety-relevant buildings are required.

3. Completely passive cooling by natural convection is adequate. No active cooling or safety cooling systems are required.

4. Virtually no open radioactive material must be handled.

5. Radioactive emissions in normal operation and during accidents are minimized.

6. Practically no secondary waste is produced.

7. High flexibility with respect to site characteristics is provided. 
8. Low initial investment is achieved by the need for relatively inexpensive storage buildings and by the successive procurement of cost-intensive storage casks.

9. Minimal decommissioning effort is anticipated.

\subsection{DESIGN CRITERIA}

\subsubsection{General}

The design of the storage casks is sufficient to achieve all safety goals, even under severe accident conditions, through

- assurance of subcriticality of the stored fuel,

- assurance of reliable removal of decay heat,

- assurance of the biological shielding function of the transport/storage casks, and

- limitation of radioactivity release to the environment.

Therefore, no additional requirements for the storage building are necessary.

In addition to meeting the IAEA requirements for fuel transport casks, the following tests have been performed to satisfy the design criterion, "no loss of integrity in case of severe accidents:"

- Drop tests with the cask cooled to $-40^{\circ} \mathrm{C}$.

- Impact test with a projectile having about $1 \mathrm{t}$ mass and $300 \mathrm{~m} / \mathrm{s}$ velocity.

As a precondition for use in interim storage, the following criteria or requirements have been promulgated for the loaded casks:

- A two-barrier system in the lid area shall be provided.

- Leaktightness of the barrier system shall be less than $10^{-7} \mathrm{~atm}-\mathrm{ml} / \mathrm{s}$.

- Integrity of the lid sealing system over 40 years should be expected.

- A maximum fuel rod cladding temperature of $390^{\circ} \mathrm{C}$ for PWR assemblies and $410^{\circ} \mathrm{C}$ for BWR fuel assemblies shall not be exceeded during storage.

- The surface dose rate limit on the cask shall be limited to $0.1 \mathrm{mSv} / \mathrm{h}(10 \mathrm{mrem} / \mathrm{h})$ for $\gamma$ - and n-radiation, each.

- The surface contamination of the cask for $\beta / y$-emitters shall be less than 3.7 $\mathrm{Bq} / \mathrm{cm}^{2}$; for $\alpha$-emitters, less than $0.37 \mathrm{~Bq} / \mathrm{cm}^{2}$.

- Residual moisture in the cask shall be no more than several grams.

\subsubsection{Protection Against External Events}

The protection against external events such as earthquakes, aircraft crashes, shock waves from explosions, etc., is provided by the storage cask design. Both accident loads and accident-induced loads are covered.

The storage building is protected against snow and wind loads according to DIN 1055 , parts 4 and 5; lightning according to relevant standards and recommendations; and sabotage by administrative measures. Flooding does not occur at any of the proposed sites. 


\subsubsection{Protection Against Internal Events}

Mechanical impact on the storage cask is possible during lift and transport operations with the building bridge crane. However, the frequency of such incidents is minimized by the design of this crane. The storage casks are designed to withstand such incidents according to their lype B (U) approval.

Explosions are very unlikely at the storage site because only small quantities of explosive materials (e.g., light oils, acetone, etc.) are stored there. Cask integrity will not be affected by any such minor explosions.

Fire was considered in the building design by provision of passive fire protection measures such as the use of fire-resistant construction materials according to DIN 4102 and limitation to a minimum of flammable construction elements and consumables. The storage cask is protected against fire by the type $B(U)$ requirements. The effect of fires following an air craft crash and kerosene spill is limited by sloping the base plate of the storage hall so that any spilled liquids will flow out of the building.

\subsection{SPENT FUEL STORAGE OPERATIONS}

The operation of the spent storage facility is divided into three parts: (1) cask reception, (2) cask storage, and (3) cask transport preparation. A general flow chart of these operations is given in Fig. 4.9(a,b $)^{15}$ and the details are described below.

\subsubsection{Cask Reception}

The transport/storage cask will be delivered by rail (Ahaus) or road (Gorleben). After passing the facility gate, the truck or railcar will be positioned in the reception area where the transport papers and seals on the cover hoods of the cask will be checked. After this, the truck or wagon will be pulled into the cask reception area of the storage hall where the transport cover hood and the shock absorbers will be removed and the cask lashings removed. The cask trunnions then will be attached to the lifting beam of the storage hall crane, the cask lifted into a vertical position, and then moved to the repair and inspection bay.

\subsubsection{Cask Storage}

After the cask has been positioned in the repair and inspection bay, the lifting beam is removed. As a first step in preparation for storage, the condition of the metal seals in the shielding and sealing lids of the flushing and cleaning connections is checked. If the seals are not intact, the tension of the bolts will be checked and adjusted. If this does not correct the problem, and it is found that the primary lid is leaking, the cask will be returned to the nuclear power plant. (The multiple sealing systems should ensure the transportability of the cask at this time.) If the metal sealings of the cover lids for the flushing and cleaning connections are defective, there is a possibility of repairing or exchanging them in the repair and inspection bay. Once the integrity of the seals has been validated, the pressure sensor is installed and the space between the primary and secondary lids is pressurized to 6 bar with helium. After proof of leaktightness, the lid cover will be installed on the cask head using the auxiliary crane, and this completes preparation of the cask for interim storage.

At this point, the lifting beam is reattached, and the cask is moved by the storage hall crane to its storage location and placed in a vertical position. The decoupling of the lifting beam and 

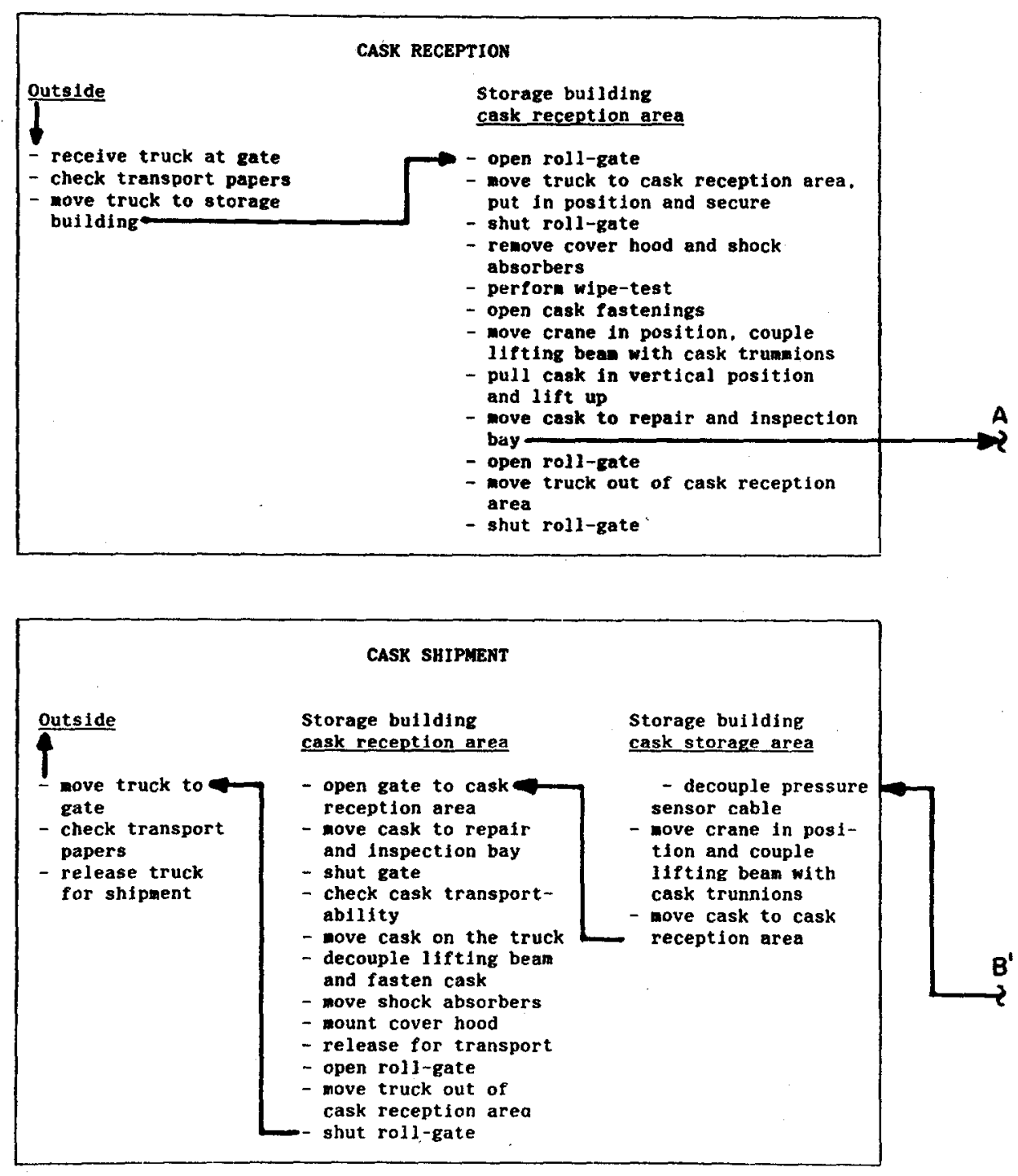

Fig. 4.9. General flow chart of spent fuel storage operations (Part a).

cask trunnion in the storage hall is performed remotely (as is the attachment of the coupling for the removal of the cask). Because of this remote operation, the crane is equipped with a very precise positioning system. Finally, the pressure sensor cable is connected to the monitoring grid so that the leak monitoring can be initiated. The repair concept to be used in the event of leaks is described in Sect. 4.2.2.

Visual inspections of the seals are performed annually. If any degradation of a seal is detected, the suspect cask will be transported to the repair and inspection bay for a more detailed investigation.

\subsubsection{Cask Transport Preparation}

To prepare a cask for transport out of the storage facility to a reprocessing plant or back to a power plant, the cask will be moved by the storage hall crane to the repair and inspection bay 


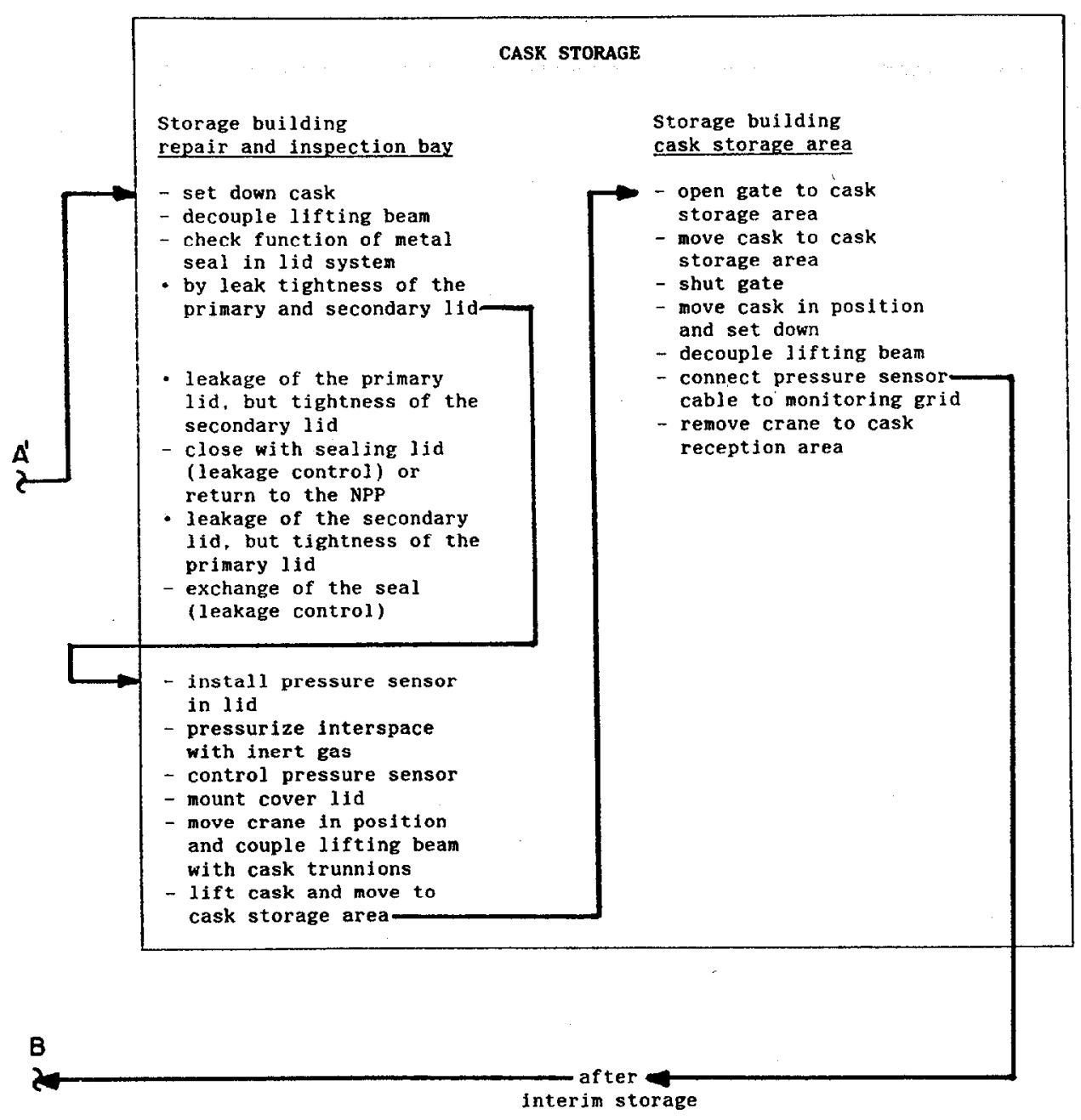

Fig. 4.9. General flow chart of spent fuel storage operations (Part b).

where its transportability is validated. The cask is then loaded on the transport vehicle in the reception area. After a transport release is obtained, the shock absorbers and cask tie-downs are attached, and the transport cover hood is placed on the cask.

\subsubsection{Cask Handling at the Nuclear Power Plants}

Cask handling procedures at the power plants do not differ between shipments off-site for reprocessing or for interim storage. Before insertion of the cask in the water pool, the external cooling fins are protected by covering them with a metal and/or plastic decontamination skirt. After proper identification, the fuel assemblies are loaded into the cask by a refueling machine. No special "acceptance criteria" for interim storage exist for the fuel asscmblics. After closure of the primary lid, the cask is lifted and the water is extracted by a suction pump to a residual water content of about $20 \mathrm{~L}$. For subsequent drying, a special vacuum drying process has been developed and demonstrated. In this process, an aerosol filter in the suction line serves for the retention of radioactive particles. The suction is continued until a pressure of 2 mbar is reached 
and, upon termination of the suction, the pressure does not increase by more than $2 \mathrm{mbar}$ over a period of 10 to $20 \mathrm{~min}$.

This drying procedure has been successfully demonstrated with different CASTOR casks and with the TN-1300. Vacuum drying times of about $18 \mathrm{~h} *$ are reported for the CASTOR Ib. ${ }^{16}$

\subsubsection{Time and Motion Studies of Cask Handling}

Although very detailed time and motion studies of the cask handling operations were performed by DWK during the design phase, and for preparation of the operating manual of the storage facilities, the studies are presently regarded by DWK as proprietary.

\subsubsection{Radiation Exposure of Plant Personnel}

The only information that has been obtained concerning interim storage experience is the information from the demonstration programs under way at the Wurgassen, Stade, and Biblis Nuclear power stations. From those programs, and from the time and motion studies of cask handling operations, the following expected radiation exposure of operating personnel can be reported.

1. The $\gamma$-plus-n dose rate at the cask surface has been shown to be less than $0.2 \mathrm{mSv} / \mathrm{h}$ $(20 \mathrm{mrem} / \mathrm{h})$.

2. In the area of the trunnions and the lid, the combined dose rate is below $0.05 \mathrm{mSv} / \mathrm{h}$ $(5 \mathrm{mrem} / \mathrm{h})$. Thus, most of the handling operations such as removal of cover hoods and shock absorbers, fastening of the lifting beam to the trunnions, inspection of the lid system, etc., can be performed in a relatively low-radiation field.

3. For certain operational steps, significant reductions in time (and radiation exposure) have been achieved by such special measures as, for example, the use of a central fastening station on the transport vehicle.

4. In the storage hall, the crane operator is protected in a shielded and air conditioned cabin. The fastening and removal of the lifting beams in that area is performed by remote control to minimize radiation exposure. The calculated annual dose rate to the crane operator is less than $0.01 \mathrm{~Sv} / \mathrm{a}(1 \mathrm{rem} / \mathrm{y})$, the limit set by the Federal regulations for "permanent working places."

5. In the cask maintenance and inspection area, temporary shielding by means of lead covers or shielding blocks can be used if necessary.

6. The cask storage area is separated from the handling area by a shielding well, so that the direct radiation from the stored casks to this area will be very low.

Photographs of a CASTOR cask being prepared for loading and transport are presented in Figs. 4.10, 4.11, and 4.12.

\subsection{STORAGE DEMONSTRATIONS AND INVESTIGATIONS}

In the course of developing the dry storage concept, several alternative dry and wet storage loading/unloading concepts were investigated by DWK. An important decision factor was the

*There is no explanation for the apparent discrepancy between the 18-h drying time reported here and the 40 -min drying time reported for the TN-12 cask in Sect 2.4 .5 . 


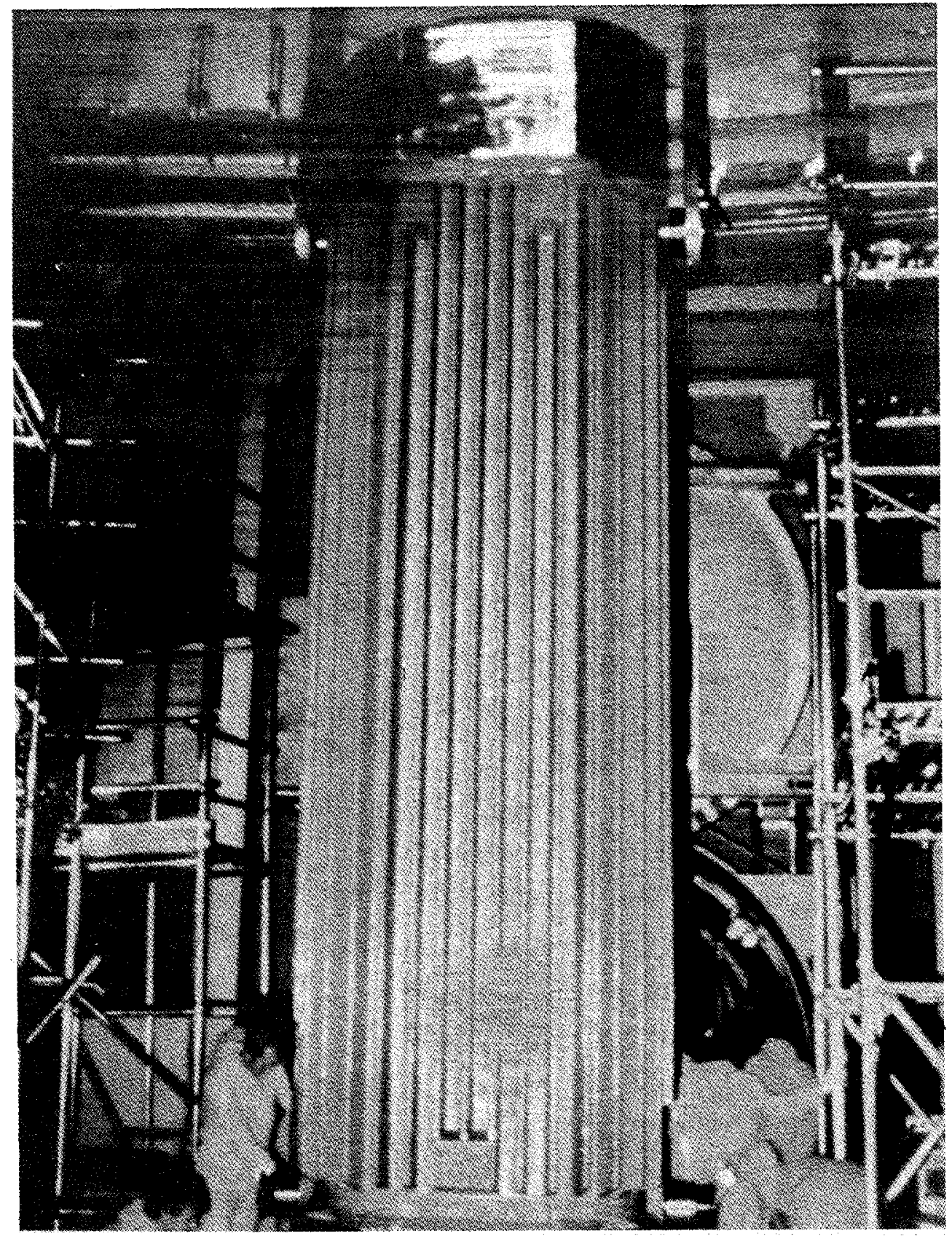

Fig. 4.10. CASTOR cask preparation for loading at a nuclear power plant.

development and demonstration of optimized cast iron transport/storage casks which incorporate all of the required safety features, even those for extreme accident assumptions. A special requirement in the FRG is that the storage facility must be able to withstand an impact of a high-speed aircraft crash. A large water pool storage facility designed to meet this particular requirement would be very expensive, but if storage in robust casks is provided, only a conventional building is required and the overall cost is acceptable. 


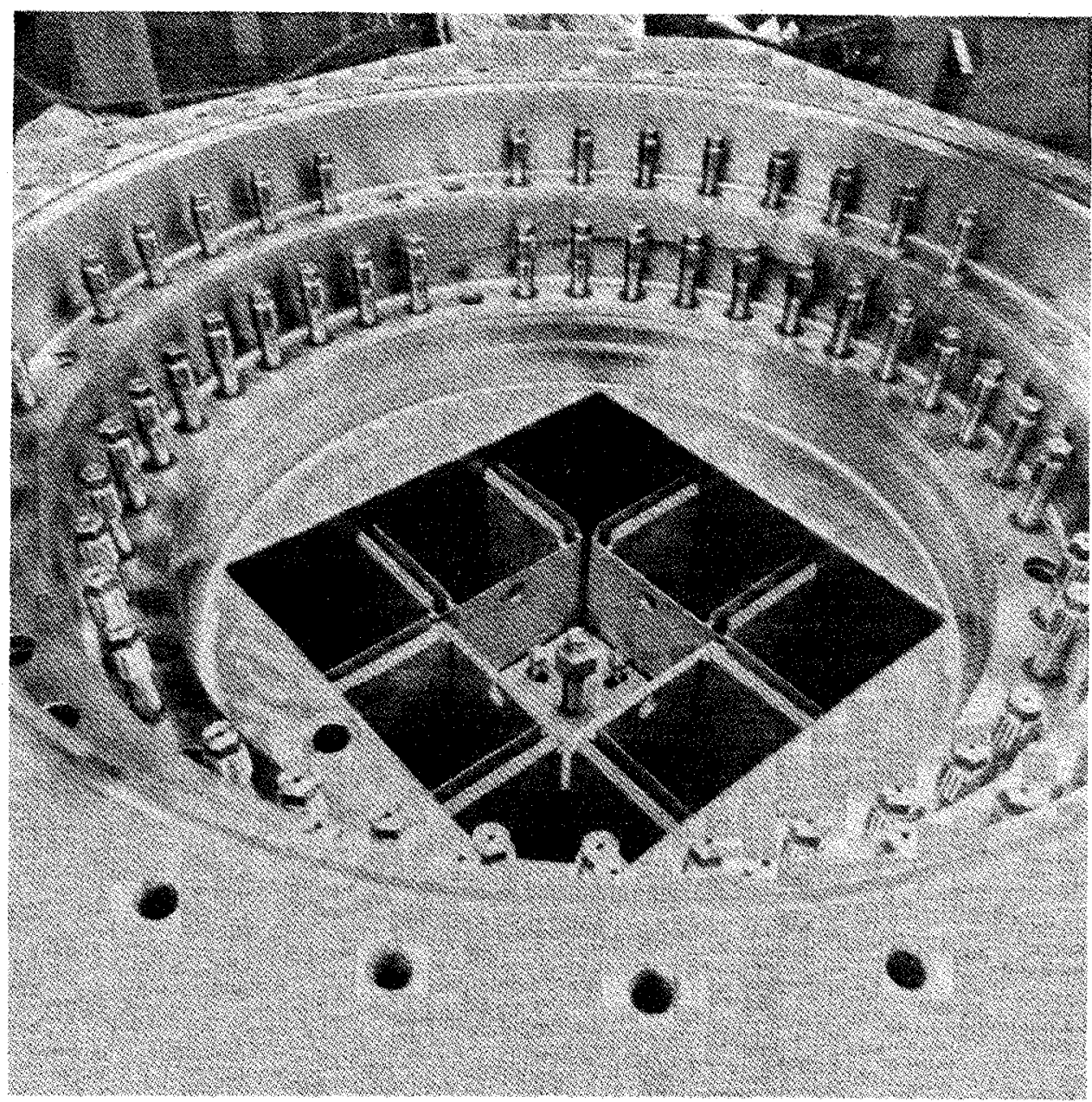

Fig. 4.11. Upper part of a CASTOR cask showing the basket used to fix the spent fuel assemblies in a safe, predetermined position.

Investigative and demonstrational programs have been carried out to acquire the technical details needed for the design and verification of the dry storage concept. They have included the following:

- evaluating the behavior of spent fuel assemblies under dry and wet storage conditions,

- showing that the heat transfer capability of the cask is adequate to maintain the temperature of the fuel cladding and cask surface within prescribed limits,

- showing that the heat transfer capability of the cask storage building is acceptable,

- demonstrating the shielding capability of the cask,

- demonstrating the long-term leaktightness of the cask,

- demonstrating the cask integrity under extreme conditions, 


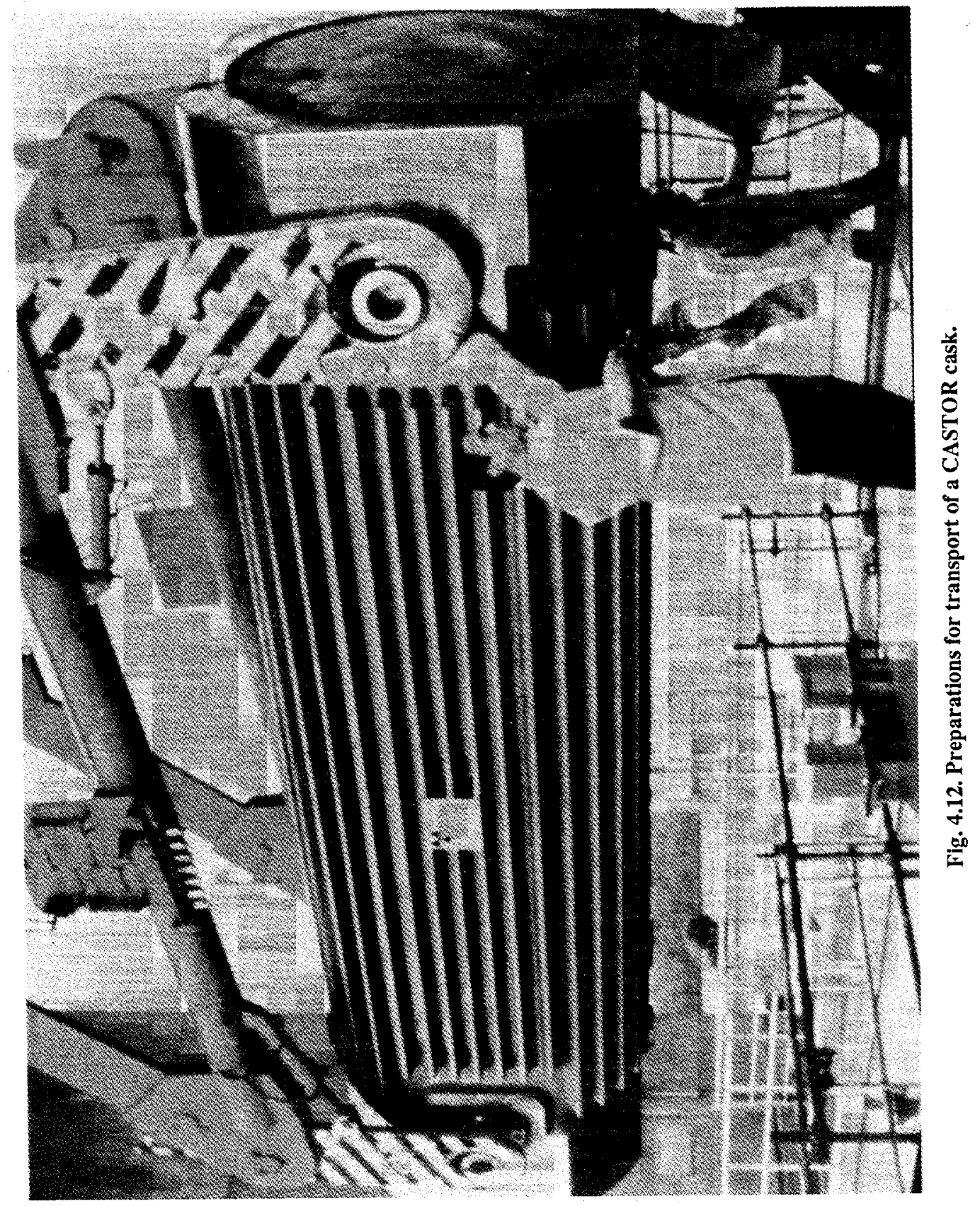


- testing cask handling in the power plants, and

- verifying cask design data.

The most important of these programs are described below.

\subsubsection{Investigation of Spent Fuel Behavior Under Dry Storage Conditions}

A very important criterion for the dry storage system concerns preservation of the fuel cladding integrity. Investigations of this problem have been performed by KWU and DWK. The properties of LWR spent fuel relative to long-term storage concepts are discussed in Ref. 17. The various mechanisms which can potentially endanger the integrity of spent fuel rods, such as corrosion from either the inside or outside, hydrogen embrittlement and thermal diffusion, crack propagation, stress corrosion cracking, and creep deformation due to internal overpressure, have been evaluated. More recent results of these investigations are reported in Refs. 18 and 19. In these programs, both intact and defective fuel rods have been studied by theoretical analysis, laboratory experiments, and performance tests. Some of the tests were made with complete assemblies. The recent results confirm earlier conclusions that, even after storage in a water pool for less than one year, subsequent dry storage of spent fuel in an inert atmosphere is safe and reliable. The principal conclusions reported in Ref. 18 are:

1. Fission product release from $\mathrm{UO}_{2}$ fuel is virtually negligible. The release occurs only during the initial heating phase and becomes zero after a few days under storage conditions.

2. Tritium is distributed $63 \%$ in the fuel and $37 \%$ in the cladding. Its release can be calculated using Sievert's Law.

3. Oxide and crud layers are very adherent and are not released from the cladding surface during dry storage.

4. Post-irradiation cladding creep rates are equal to or less than those of unirradiated Zircaloy. The primary creep depends on the stress state prior to shutdown.

5. The integrity of the fuel rod is not affected by iodine stress corrosion cracking.

6. Defective "water-logged" fuel rods can be dried effectively using the standard cask drying procedures.

7. Aerosol production from mechanically impacted spent fuel is very low, and the size of the particles is relatively coarse.

\subsubsection{Dry Storage Cask Demonstration}

The results of an extensive demonstration program with a CASTOR cask at the Wurgassen nuclear power plant are reported in Ref. 20 , and with a TN-1300 cask at the Biblis plant in Ref. 16. In Ref. 21 a recent survey is given of dry storage cask demonstrations with CASTOR-I and TN-1300 casks. Characteristics of the demonstrations and the program sequence are shown in Fig. 4.13.21

In summary, it can be stated that:

- in-pool loading and unloading of transport/storage casks have been successfully demonstrated

- cask design parameters have been verified in practice 


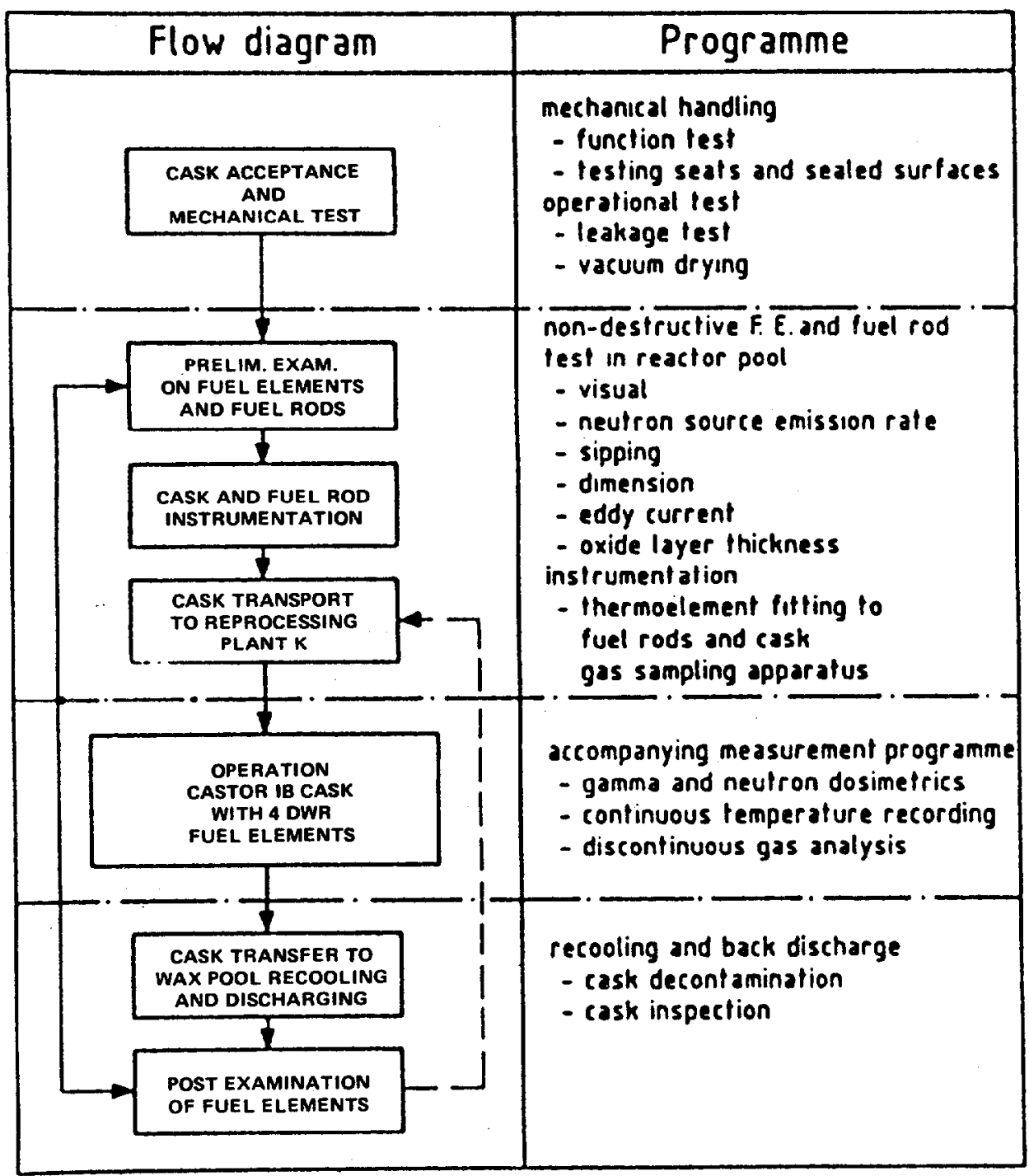

Fig. 4.13. Survey of dry cask storage demonstrations.

- radiation levels to operators are extremely low

- no rods have failed due to dry storage, even over a wide range of storage temperatures

\subsubsection{Analysis and Simulation of Heat Transfer in the Storage Building}

During design of the storage facilities Gorleben and Ahaus, the decay heat transfer from the cask surfacc by natural convection of air was analyzed and experimentally investigated in a 1:5 scale test setup. ${ }^{22}$ The models were heated electrically and temperatures of the casks and the air were measured. Air flow paths and velocities were also determined. It was found that the cooling conditions at various cask storage positions differ very little, and the surface temperatures of casks stored inside the building are a maximum of $10^{\circ} \mathrm{K}$ higher than those of a free-standing cask. 


\subsection{REFERENCES FOR SECTION 4}

1. Kernforschungszentrum Karlsruhc, System Study of Alternative Waste Management Technologies, Main Volume, compiled by the Project Group for Alternative Waste Management Technologies (December 1984), ORNL/TR-86/31.

2. J. Mischke, "Entsorgung kerntechnischer Anlagen," BAM Sonderkolloquiium, BAM Forschungsbericht 122 (December 1985).

3. Jahrbuch der Atomwirtschaft, 1986.

4. H. Malmstrom et al., "1500-tU Spent Fuel Element Storage Plant Ahaus," pp. 955-960 in PATRAM '80, Proceedings of the Sixth International Symposium on Packaging and Transport of Radioactive Materials, Berlin, November 10-14, 1980.

5. K. Einfeld and F. W. Popp, "Dry Storage Systems Using Casks for Long Term Storage in an AFR and Repository," pp. S-99 through S-117 in Vol. 1 of Proceedings of Third International Spent fuel Storage Technology Symposium/Workshop, April 8-10, 1986, Seattle, Washington, CONF-860417 (1986).

6. K. Einfeld, "Pilot Plant for Spent Fuel Conditioning at Gorleben," Nuclear Europe 3-4/1987, p. 21.

7. J. Meinecke, "Die zentrale Zwischenlagerung von ausgedienten Brennelementen (Gorleben, Ahaus), SVA, Abfallbewirtschaftung im Kernkraftwerk (December 1986).

8. Deutsche Gesellschaft fur Wiederaufarbeitung von Kernbrennstoffen mbH (DWK), Beschreibung des Brennelementlagers und des Zwischenlagers zur Schwachradioaktive Abfalle in Gorleben (September 1980).

9. Brennelementlager Gorleben GmbH (Fuel Element Storage Company Gorleben Ltd.), The Gorleben Interim Store, brochure (in English) dated October 1986.

10. H. Keese et al., "Storage of Spent Fuel in Transport/Storage Casks," pp. 931-938 in PATRAM '80, Proceedings of the Sixth International Symposium on Packaging and Transport of Radioactive Materials, Berlin, November 10-14, 1980.

11. B. Droste, Uberblick uber die behalterspezifischen Gesichtspunkte der Zwischenlagerung abgebrannter Kernbrennstoffe," BAM Sonderkolloquium, BAM Forschungsbericht 122 (December 1985).

12. DWK, CASTOR der Transport-und Lagerbehalter, brochure (in German) dated March 1985.

13. DWK, Transport-und Lagerbehalter TN-1300, brochure (in German) dated March 1985.

14. Transnuklear GmbH, Transport/Storage Cask TN 1300 Technical Description, W. Anspach, compiler, TN 8015, Rev. 7 (January 1984), English translation by C. B. Jones, Transnuklear GmbH, Postfach 110030, D-6450 Hanau 11.

15. DWK, Safety Analysis Report of the Interim Storage Facility Ahaus (July 1982).

16. W. Botzen et al., "Erprobung des TN 1300 Transport/Lagerbehalters mit Biblis-Brennelementen," Jahrestagung Kerntechnik 1985.

17. M. Peehs, R. Kuhnel, and G. Kaspor, "Discussion of Spent Fuel Properties in Relation to Actual Long-Term Storage Concepts," Trans. Am. Nucl. Soc. 40, 135 (1982). 
18. M. Peehs, R. Bokelmann, and J. Fleisch, "Spent Fuel Dry Storage Performance in Inert Atmosphere," pp. S-215 through S-230 in Vol. 1 of Proceedings of Third International Spent Fuel Storage Technology Symposium/Workshop, April 8-10, 1986, Seattle, Washington, CONF-860417 (1986).

19. M. Peehs, G. Kaspar, and E. Steinberg, "Experimentally Based Spent Fuel Dry Storage Performance Criteria," pp. S-316 through S-331 in Vol. 1 of Proceedings of Third International Spent Fuel Storage Technology Symposium/Workshop, April 8-10, 1986, Seattle, Washington, CONF-860417 (1986).

20. J. Fleisch et al., "Erfahrungen mit einen Transport und Lagerbahalter vom Typ CASTOR im Kernkraftwerk Wurgassen," Atomwirtschaft, July/August 1983.

21. H. Spilker and J. Fleisch, "Dry Storage Demonstrations of CASTOR I and TN 1300 Casks," pp. S-1 through S-19 in Vol. 1 of Proceedings of Third International Spent Fuel Storage Technology Symposium/Workshop, April 8-10, 1986, Seattle, Washington, CONF-860417 (1986).

22. W. von Heesen et al., "Heat Transfer from Transport Cask Storage Facilities for Spent Fuel Elements," Nucl. Technol. 62, 62-70 (July 1983). 


\section{LIST OF ABBREVIATIONS AND ACRONYMS}

AA Asea-Atom, Swedish designer and developer of nuclear systems and equipment

AFR Away from reactor (spent fuel storage facility)

AGR Advanced gas-cooled reactor (British)

AML A buffer storage unit for receiving and shipping fuel transport casks at La Hague

AtG Federal Atomic Energy Act (FRG)

AVH Atlier de Vitrification de La Hague, the French high-level vitrification facility at La Hague

AVM Atlier de Vitrification de Marcoule, the French high-level waste vitrification facility at Marcoule

BAM Bundesanstalt fur Materialprufung, the West German licensing agency for radioactive facilities

BLA Rock cavern for low-level waste at the Swedish Final Repository for Reactor Waste

BMA Rock cavern for medium-level waste at the Swedish Final Repository for Reactor Waste

BNFL British Nuclear Fuels Limited

BTF Rock caverns for waste packaged in concrete tanks at the Swedish Final Repository for Reactor Waste

BWR Boiling water reactor

CEA Commissariat a l'Energie Atomique, French Atomic Energy Commission

CLAB Central Storage Facility for Spent Fuel (Sweden) -

COGEMA Compagnie General des Matieres Nucleaires, General Company for Nuclear Materials (French)

DEC Disassembly and consolidation system for LWR spent fuel (French)

DIN West German national radiation standards

DWK Deutsche Gesselschaft fur Wiederaufarbeitung von Kernbrennstoffen mbH, German Company for Reprocessing of Spent Nuclear Fuel Ltd. (FRG)

FA Fuel assembly

FBR Fast breeder reactor

FRG Federal Republic of Germany, or West Germany 
FWMS Federal Waste Management System (United States)

GCR Gas-cooled reactor

GEC GEC Energy Systems Ltd., British designer and supplier of nuclear systems and equipment

GNS Gesselschaft fur Nuklear Service mbH, Company for Nuclear Service, Ltd., West German designer and developer of spent fuel transport casks

HLW High-level waste

HVAC High vacuum

ISFSI Independent Spent Fuel Storage Installation, Surry Power Station, Virginia, USA

LK Lemer \& Cie, French designer of transfer and transport systems

LWR Light-water reactor

MERC Mobile equipment replacement cask (French), for remote maintenance of process equipment

MVDS Modular Vault Dry Storage (British)

MRS Monitored retrieval storage (facility)

MX Magnox (British), magnesium oxide-clad uranium fuel

NPH Underwater unloading unit for full transport casks at La Hague

OKG OKG Aktiebolag, a Swedish nuclear utility and operator of the CLAB

PAE Project Andere Entsorgungstechniken, Project for Alternative Disposal Techniques (FRG)

PTB Physikalisch Technische Bundesanstalt, Federal office responsible for construction and operation of installations for long-term storage and disposal of radioactive waste in the FRG

PWR Pressurized water reactor

SFL Final Repository for Long-Lived Waste (Sweden)

SFR Final Repository for Reactor Waste (Sweden)

SGN Societe Generale pour les Techniques Nouvelles, French designer and supplier of nuclear systems and equipment

SKB Svensk Karnbranslehantering AB, Swedish Nuclear Fuel and Waste Management Company

THORP Thermal Oxide Reprocessing Plant at Sellafield, United Kingdom

t Metric ton(s)

TN Transnucleaire (Transnuklear $\mathrm{GmbH}$ ) French (and West German) designer and developer of transport systems for nuclear materials

TO A dry unloading unit for fuel transport casks at La liague 
TOR Traitment Oxyde Rapide, French facility for dry storage of fast breeder reactor spent fuel

tU Metric tons of uranium

TVA Tennessee Valley Authority

UK United Kingdom

UP2 and Original and expanded capacity fuel reprocessing plant at La Hague

UP2-800

UP3 Fuel reprocessing plant at La Hague

U.S. United States

USAEC United States Atomic Energy Commission

USDOE - United States Department of Energy

USNRC United States Nuclear Regulatory Commission

WAK Wiederaufarbeitungsanlage Karlsruhe, the Karlsruhe Reprocessing (pilot) Plant

WAW Wiederaufarbeitungsanlage Wackersdorf, the Wackersdorf Reprocessing Plant 


\section{LIST OF FIGURES}

Fig. 2.1. 130-t overhead bridge crane for spent fuel cask handling.

Fig. 2.2. Mobile rack for spent fuel casks mounted on transfer platform.

Fig. 2.3. Spent fuel transport cask storage area at COGEMA - La Hague Plant.

Fig. 2.4. Decontamination shell on the upper platform of a cask handling facility.

Fig. 2.5. Cask cavity drying system.

Fig. 2.6. Cask external cooling system.

Fig. 2.7. Cask internal cooling system.

Fig. 2.8. Cask handling operations at dry unloading facility.

Fig. 2.9. Model of "TO" dry receiving/unloading facility.

Fig. 2.10. Model of "TO" cask preparation facility.

Fig. 2.11. Raising the spent fuel cask into a self-propelled dolly.

Fig. 2.12. Mating of cask with unloading cell.

Fig. 2.13. Schematic diagram of COGEMA - La Hague spent fuel receiving and storage facilities for the UP2-800 and UP3 reprocessing plants.

Fig. 2.14. Schematic flow of spent fuel for NPH facility at COGEMA - La Hague Plant.

Fig. 2.15. NPH facility cask unloading pool at COGEMA - La Hague Plant.

Fig. 2.16. NPH facility storage pool at COGEMA - La Hague Plant.

Fig. 2.17. Pole crane for underwater handling of spent fuel storage baskets at COGEMA La Hague Plant.

Fig. 2.18. C pond at COGEMA - La Hague Plant.

Fig. 2.19. Pool shock absorber pads.

Fig. 2.20. Heat exchanger for spent fuel storage pool.

Fig. 2.21. Pool bottom cleaning equipment.

Fig. 2.22. Schematic of modular vault dry storage system.

Fig. 2.23. Alternative MVDS cooling path.

Fig. 2.24. Conceptual MVDS facility.

Fig. 2.25. Wylfa dry storage system.

Fig. 2.26. AGR dry vault storage facility. 
Fig. 2.27. GEC conceptual small dry vault storage facility.

Fig. 2.28. Dry HLW storage facility al COGEMA - Marcoule plant.

Fig. 2.29. Diagram of cooling circuits used in dry storage of HLW.

Fig. 2.30. Dry spent fuel storage facility at the TOR FBR reprocessing plant at Marcoule.

Fig. 2.31. DEC spent fuel disassembly and consolidation facility.

Fig. 2.32. Flowsheet for disassembly and consolidation operations (Part I).

Fig. 2.33. Flowsheet for disassembly and consolidation opcrations (Part II).

Fig. 2.34. Flowsheet for the volume reduction process.

Fig. 2.35. Welding machine for canister lid.

Fig. 2.36. High-pressure decontamination system for HLW canisters.

Fig. 2.37. Contamination monitoring of HLW canisters.

Fig. 2.38. MERC equipment being loaded on a horizontal axis cradle.

Fig. 2.39. Sliding hatch MERC.

Fig. 2.40. Revolving MERC.

Fig. 2.41. Equipment removal preparation.

Fig. 2.42. Equipment removal by MERC.

Fig. 2.43. Transfer of removed equipment.

Fig. 2.44. UP2 reprocessing and operational exposure history.

Fig. 3.1 The Swedish nuclear power program.

Fig. 3.2 Swedish waste management strategy.

Fig. 3.3. M/S Sigyn at the Simpevarp harbor outside Oskarshamn.

Fig. 3.4. Transport cask TN $17 / \mathrm{Mk} 2$.

Fig. 3.5. Terminal vehicles with transport casks.

Fig. 3.6. Transport flasks secured in the cargo hold of M/S Sigyn.

Fig. 3.7. General layout of the CLAB.

Fig. 3.8. Sequential spent fuel handling steps at the CLAB.

Fig. 3.9. Layout of tunnels and caverns in the SFR.

Fig. 3.10. Site layout of surface facilities.

Fig. 3.11. Tunnels and caverns in construction Phase 1.

Fig. 3.12. Silo repository.

Fig. 3.13. BMA rock cavern for medium-level waste.

Fig. 4.1. Site plan of the Gorleben interim storage facility.

Fig. 4.2. Perspective view of the Gorleben interim storage facility. 
Fig. 4.3. Sketch of the spent fuel assembly storage hall at Gorleben.

Fig. 4.4. Aerial view of the Gorleben interim storage facility.

Fig. 4.5. CASTOR cask (without spent fuel) in the repair and inspection bay.

Fig. 4.6. Storage hall for casks.

Fig. 4.7. Founding of a CASTOR cask body.

Fig. 4.8. Illustration of a generic transport/storage cask double-lid sealing system.

Fig. 4.9(a). General flow chart of spent fuel storage operations.

Fig. 4.9(b). General flow chart of spent fuel storage operations.

Fig. 4.10. CASTOR cask preparation for loading at a nuclear power plant.

Fig. 4.11. Upper part of a CASTOR cask showing the basket used to fix the spent fuel assemblies in a safe, predetermined position.

Fig. 4.12. Preparations for transport of a CASTOR cask.

Fig. 4.13. Survey of dry cask storage demonstrations. 


\section{LIST OF TABLES}

Table 2.1. General description of French spent fuel transport casks

Table 2.2. Summary description of TN-24 casks

Table 2.3. Ocean-going radioactive materials carriers

Table 2.4. La Hague (UP2) reprocessing history

Table 3.1. Selected data on the M/S Sigyn

Table 3.2. Selected data on the CLAB

Table 3.3. Comparison of calculated and measured occupational doses

Table 3.4. Characteristics of medium- and low-level wastes

Table 4.1. Available water pool storage capacities at FRG nuclear power plants and expected dates when filled

Table 4.2. Characteristics of casks acceptable for storage at the Gorleben interim storage facility 
ORNL/TM-10696

Dist. Category UC-71 and UC-85

\section{INTERNAL DISTRIBUTION}

1. C. R. Attaway

2. J. O. Blomeke

3. W. D. Burch

4. A. G. Croff

5. C. W. Forsberg

6. E. J. Frederick

7. D. S. Joy

8. S. B. Ludwig

9. S. A. Meacham

10. L. G. Medley

11. J. R. Merriman

12. K. J. Notz

13. W. H. Pechin

14. J. E. Ratledge
15. R. R. Rawl

16. M. J. Rennich

17. T. H. Row

18. J. H. Saling

19. L. B. Shappert

20-24. H. R. Yook

25. Central Research Library

26. Document Reference Section

27-28. Laboratory Records

29. Laboratory Records ORNL-RC

30-31. FRD Publications Office

32. ORNL Patent Office

\section{EXTERNAL DISTRIBUTION}

33. G. Allen, Sandia National Laboratory, P.O. Box 5800, Albuquerque, NM 87185.

34. M. J. Barainca, Department of Energy-Idaho Operations Office, 785 DOE Place, Idaho Falls, ID 83402.

35. L. H. Barrett, Department of Energy-Office of Civilian Radioactive Waste Management, Forrestal Building, 1000 Independence Avenue, S.W., Washington, DC 20585.

36. G. H. Beeman, Pacific Northwest Laboratory, P.O. Box 999, Richland, WA 99352.

37. C. Boggs-Mayes, Department of Energy-Chicago Operations Office, 9800 S. Cass Avenue, Chicago, IL 60439.

38. A. B. Brownstein, Department of Energy-Office of Civilian Radioactive Waste Management, Forrestal Building, 1000 Independence Avenue, S.W., Washington, DC 20585.

39. J. H. Carlson, Department of Energy-Office of Civilian Radioactive Waste Management, Forrestal Building, 1000 Independence Avenue, S.W., Washington, DC 20585.

40. A. W. Dennis, Sandia National Laboratory, P.O. Box 5800, Albuquerque, NM 87185.

41. J. DiNunno, Weston, 955 L'Enfant Plaza, S.W., Eight Floor, Washington, DC 20024.

42. D. Dippold, Battelle/Office of Transportation Systems and Planning, 505 King Avenue, Columbus, OH 43201.

43. R. Emmett, H\&R Technical Associates, 575 Oak Ridge Turnpike, Oak Ridge, TN 37831.

44. M. W. Frei, Department of Energy-Office of Civilian Radioactive Waste Management, Forrestal Building, 1000 Independence Avenue, S.W., Washington, DC 20585. 
45. P. J. Gross, Department of Energy-Oak Ridge Operations, P.O. Box E, Oak Ridge, TN 37831.

46. H. J. Hale, Department of Energy-Office of Civilian Radioactive Waste Management, Forrestal Building, 1000 Independence Avenue, S.W., Washington, DC 20585.

47. G. Hartkopf, Department of Energy-Office of Civilian Radioactive Waste Management, Forrestal Building, 1000 Independence Avenue, S.W., Washington, DC 20585.

48. M. M. Heiskell, Department of Energy-Oak Ridge Operations, P.O. Box E, Oak Ridge, TN 37831.

49. P. Hoffman, Battelle/Office of Transportation Systems and Planning, 505 King Avenue, Columbus, $\mathrm{OH} 43201$.

50. E. R. Johnson, E. R. Johnson Associates, Inc., 10461 White Granite Drive, Suite 204, Oakton, VA 22124.

51. B. F. Judson, General Electric Company, 175 Curtner Avenue, San Jose, CA 95125.

52. S. H. Kale, Department of Energy-Office of Civilian Radioactive Waste Management, Forrestal Building, 1000 Independence Avenue, S.W., Washington, DC 20585.

53. D. Kenyon, Department of Energy-Richland Operations Office, P.O. Box 550, Richland, WA 99352.

54. K. A. Klein, Department of Energy-Office of Civilian Radioactive Waste Management, Forrestal Building, 1000 Independence Avenue, S.W., Washington, DC 20585.

55. S. Kraft, UNWMG, Edison Electric Institute, 1111 19th Street N.W., Washington, DC 20036.

56. R. W. Lambert, Electric Power Research Institute, P.O. Box 10412, Palo Alto, CA 94303.

57. J. Leatham, EG\&G Idaho, Inc., P.O. Box 1625, Idaho Falls, ID 83415.

58. W. J. Lee, Nuclear Assurance Corporation, 6251 Crooked Creek Road, Suite 200, Norcross, GA 30092.

59. N. B. McLeod, E. R. Johnson Associates, Inc., 10461 White Granite Drive, Suite 204, Oakton, VA 22124.

60. R. Morrisette, Science Applications International Corporation, 101 Convention Center Drive, Las Vegas, NV 89109.

61-64. T. D. Nguyen, Department of Energy-Office of Civilian Radioactive Waste Management, Forrestal Building, 1000 Independence Avenue, S.W., Washington, DC 20585.

65. W. Pardue, Battelle/Office of Transportation Systems and Planning, 505 King Avenue, Columbus, $\mathrm{OH} 43201$.

66. S. S. Perkins, Department of Energy-Oak Ridge Operations, P.O. Box E, Oak Ridge, TN 37831.

67. R. W. Peterson, Battelle/Office of Transportation Systems and Planning, 505 King Avenue, Columbus, $\mathrm{OH} 43201$.

68. W. R. Rhyne, H\&R Technical Associates, 575 Oak Ridge Turnpike, Oak Ridge, TN 37831.

69. K. J. Schneider, Pacific Northwest Laboratory, P.O. Box 999, Richland, WA 99352.

70. D. E. Shelor, Department of Energy-Office of Civilian Radioactive Waste Management, Forrestal Building, 1000 Independence Avenue, S.W., Washington, DC 20585.

71. J. R. Siegel, U.S. Council For Energy Awareness, 1776 I Street, N.W., Suite 400, Washington, DC 20006

72. L. Skousen, Department of Energy-Nevada Operations Office, P.O. Box 14100, Las Vegas, NV 89114. 
73. R. Stein, Department of Energy-Office of Civilian Radioactive Waste Management, Forrestal Building, 1000 Independence Avenue, S.W., Washington, DC 20585.

74. E. Svenson, Department of Energy-Office of Civilian Radioactive Waste Management, Forrestal Building, 1000 Independence Avenue, S.W., Washington, DC 20585.

75. J. A. Tori, Department of Energy_Office of Nuclear Energy, 19901 Germantown Road, Germantown, MD 20874.

76. L. Trosten, NTG, LeBoeuf, Lamb, Leiby \& McRae, 1333 New Hampshire, N.W., Suite 1100, Washington DC 20039.

77. L. W. Vogel, Science Applications International Corporation, 1710, Goodbridge Drive, McLean, VA 22102.

78. E. Wilmot, Department of Energy-Office of Civilian Radioactive Waste Management, Forrestal Building, 1000 Independence Avenue, S.W., Washington, DC 20585.

79. R. Williams, Electric Power Research Institute, P.O. Box 10412, Palo Alto, CA 94303.

80. W. Wowak, Weston, 955 L'Enfant Plaza, S.W., Eight Floor, Washington, DC 20024.

81. K. Yates, Battelle/Office of Transportation Systems and Planning, 505 King Avenue, Columbus, OH 43201.

82. Office of Assistant Manager, Energy Research and Development, Department of Energy-Oak Ridge Operations, P.O. Box E, Oak Ridge, TN 37831.

83-322. Given distribution as shown in DOE/OSTI under UC-71 and UC-85. 